FIFTEENTH CENSUS OF THE UNITED STATES : 1930

CENSUS OF AGRICULTURE

\title{
THE NEGRO FARMER IN THE UNITED STATES
}

U. S. DEPARTMENT OF COMMERCE BUREAU OF THE CENSUS 
Return this book on or before the Latest Date stamped below. A charge is made on all overdue books.

\section{U. of I. Library}

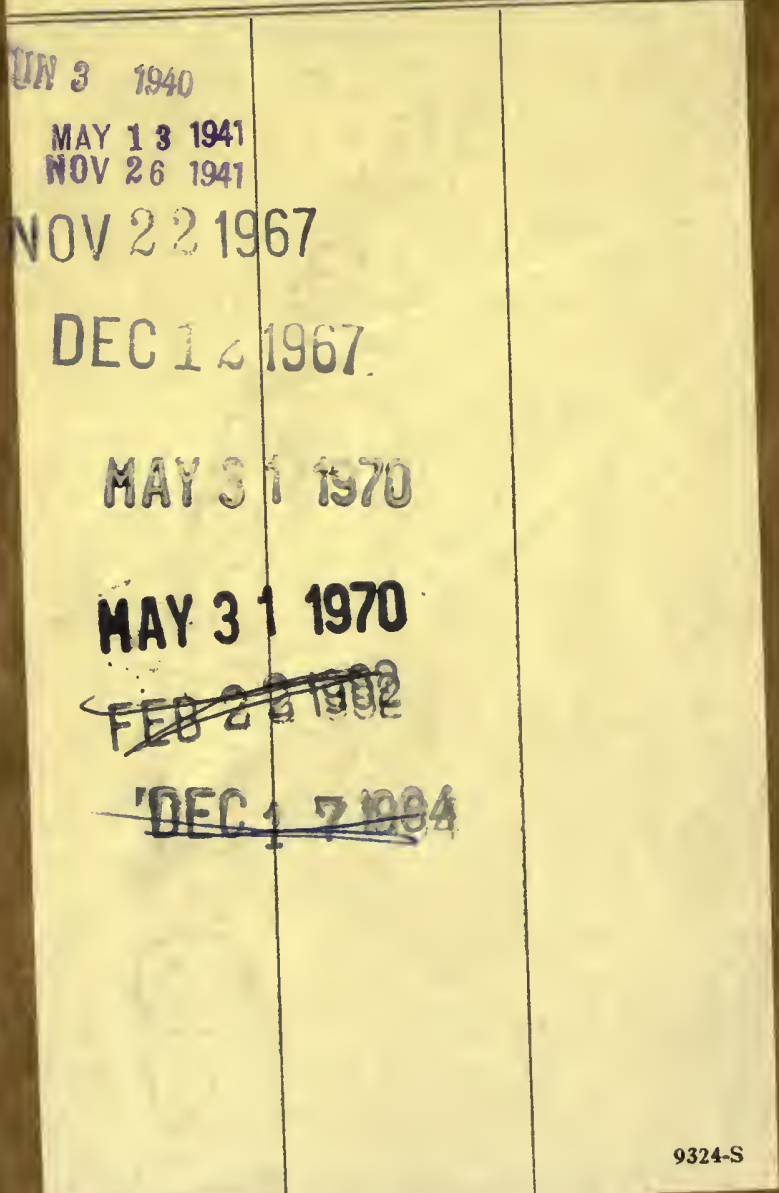





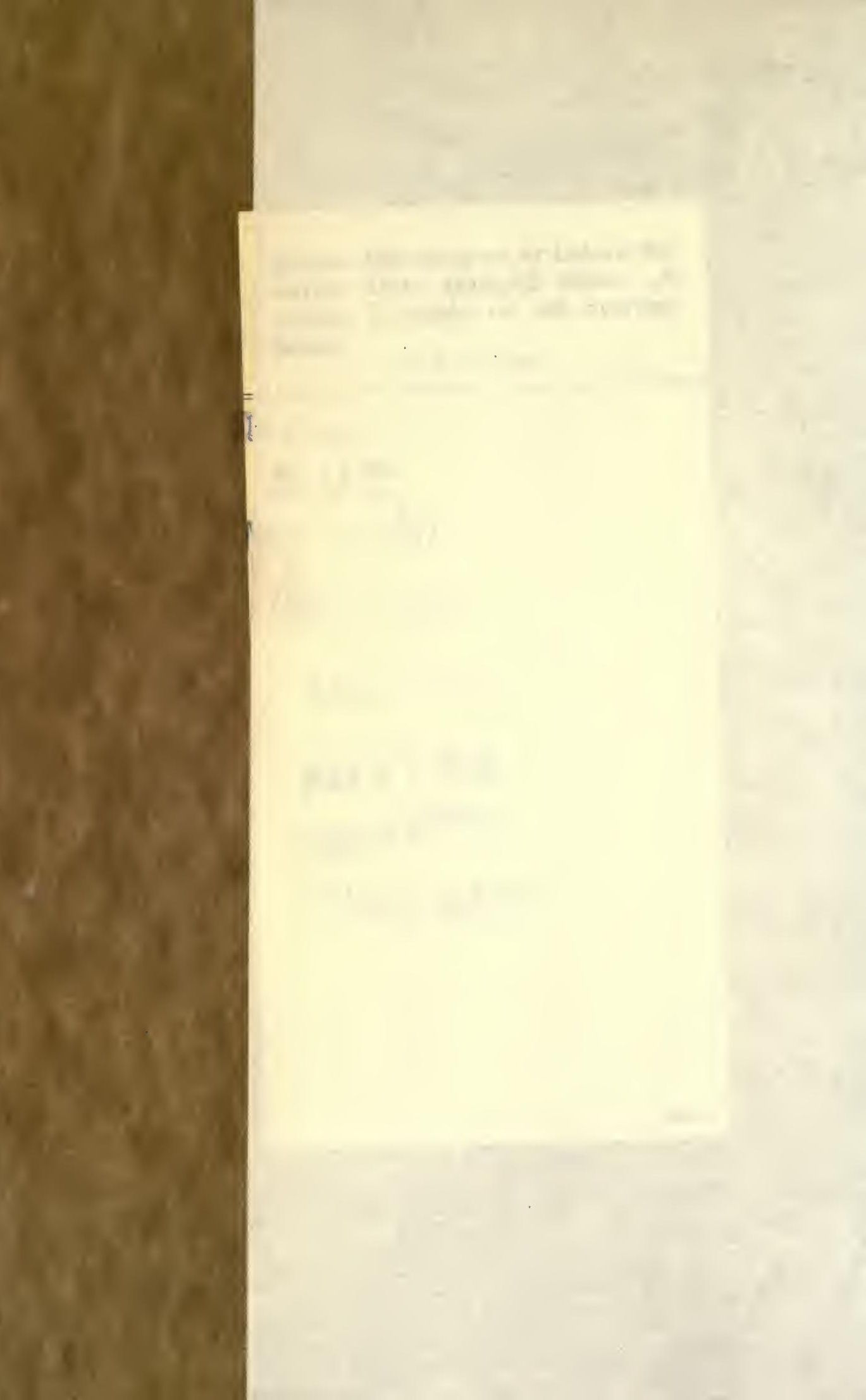




\title{
U. S. DEPARTMENT OF COMMERCE
}

Roy D. Chapin, Secretary

BUREAU OF THE CENSUS

W. M. Steuart, Director

FIFTEENTH CENSUS OF THE UNITED STATES : 1930

\author{
CENSUS OF AGRICULTURE
}

\section{THE NEGRO FARMER IN THE UNITED STATES}

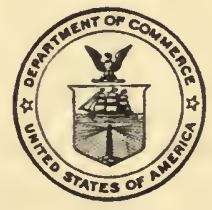

UNITED STATES

GOVERNMENT PRINTING OFFICE

WASHINGTON : 1933 


\section{CONTENTS}

INTRODUCTION

Table

\section{TEXT TABLES}

1.-Total Negro population, with percentages by sections: 1930 and 1920

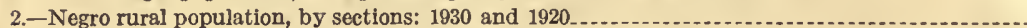

3.-Negro rural and urban population, by sections, divisions, and States: 1930 and $1910 \ldots . . . . . .$.

4.-Population and farm operators by racial classes: 1930 and 1920 .

5.-Increase in population and number of farm operators, 1920 to 1930, by racial classes; and number of operators per 1,000 population of each class: 1930 and 1920.

6. - Number of counties in each State reporting Negro inhabitants and Negro farmers, $1930 . . . . . .$.

7.-Number of Negro and white farm operators, by sections and Southern divisions: 1930 and 1920.

8.-Negro and white farm operators-Increase, 1920 to 1930, and number of operators per 1,000 population, 1930 and 1920 , by sections and Southern divisions.

9.-Colored farm operators, by age, in Southern divisions and States, and selected Northern States, 1930.

10.-Colored farm owners, by age, in Southern divisions and States, and selected Northern States, 1930.

11. - Colored farm operators, by years on farm, in Southern divisions and States, and selected Northern States, 1930

12.-All land in farms (acres), and area in square miles, by sections and Southern divisions: 1930 and 1920

13.-Acreage in farms operated by Negroes and whites, 1930 and 1920; and area in square miles, 1930, by sections and Southeru divisions.

14. - Per cent distribution of acreage in farms operated by Negroes and whites, by sections and Southern divisions: 1930 and 1920

15.-Increase in acreage and square miles in farms operated by Negroes and whites, 1920 to 1930 , by sections and Southern divisions.

16.-Average acreage per farm of Negro and white operators, by sections, and Southern divisions and States: 1930 and 1920

17.-Value of land and buildings of all farms and of farms operated by Negroes, by sections: 1930 and 1920.

18.-Number of farms and value of land and buildings of Negro farm operators in the Southern States with rank of the States: 1930 and 1920

19.-Number of farms and value of land and buildings of Negro operators in the Northern and Western States, with rank of the States: 1930 and 1920.

20.-Number of Negro farm operators, 1930 and 1910, with increase during the 20-year period, 1910 to 1930 , by sections, divisions, and States.

21. Land in farms operated by Negroes, 1930 and 1910, with increase during the 20-year period, 1910 to 1930 , by sections, divisions, and States

22.-Value of land and buildings of farms operated by Negroes, 1930 and 1910, with increase during

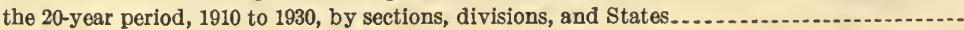

23.-Number of farm operators, by color and tenure, by sections, 1930 .

24. - Number of Negro and white farm operators in the United States, by tenure and number of Negro

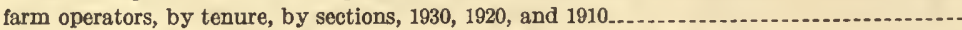

25.-Per cent distribution of owned and tenant farms operated by Negroes by sections and States, 1930,1920 , and 1910.

26.-Number of acres in farms operated by negroes with percentages, by tenure, by sections: 1930 and 1920

27. - Average value of land and buildings of farms operated by Negroes, per farm and per acre, by tenure, by sections, and Southern divisions: 1930 and 1920

28.-Value of land in farms operated by Negroes, by tenure, by sections, and divisions, 1930 .........

29.-A verage size and average value of farms and farm acreage operated by Negro owners and tenants by sections, Southern divisions, and States, 1930

30-Value of all buildings on tarms operated by Negroes, by tenure, by sections, and divisions, 1930. 
31.-Value of land and buildings for farms operated by Negroes, by tenure, by sections: 1930 and 1920

32.- Farms operated by colored full owners, classifled according to mortgage status, by Southern divisions and States, and selected Northern States, 1930

33.-Value of implements and machinery on farms operated by Negroes, by tenure, by sections, divisions, and States, 1930.

34.-Farm machinery reported by colored farm operators in the Southern divisions and States, and in selected Northern States, 1930.

35.-Number of Negro farm operators, by tenure, by sections, divisions, and States: 1930 and 1920 ..

36.-All land in farms operated by Negroes, by tenure, by sections, divisions, and States: 1930 and 1920.

37.-Value of land and buildings on farms operated by Negroes, by tenure, by sections, divisions, and States: 1930 and 1920.

38. - Farms operated by Negroes-Number, acreage, and value of specifled classes of farm property, by States and countles, 1930

\section{MAPS}

Map of the United States, showing the sections . . .

Percentage of total number of farms operated by Negro farmers by States, $1930 \ldots \ldots . . . . . . . . . . . .$.

Percentage of all land in farms operated by Negro farmers by States, 1930 . ...................... 21

Percentage Negro owners are of all Negro farm operators (Southern States only), 1930............. 35

Percentage Negro tenants are of all Negro farm operators, by States, 1930 


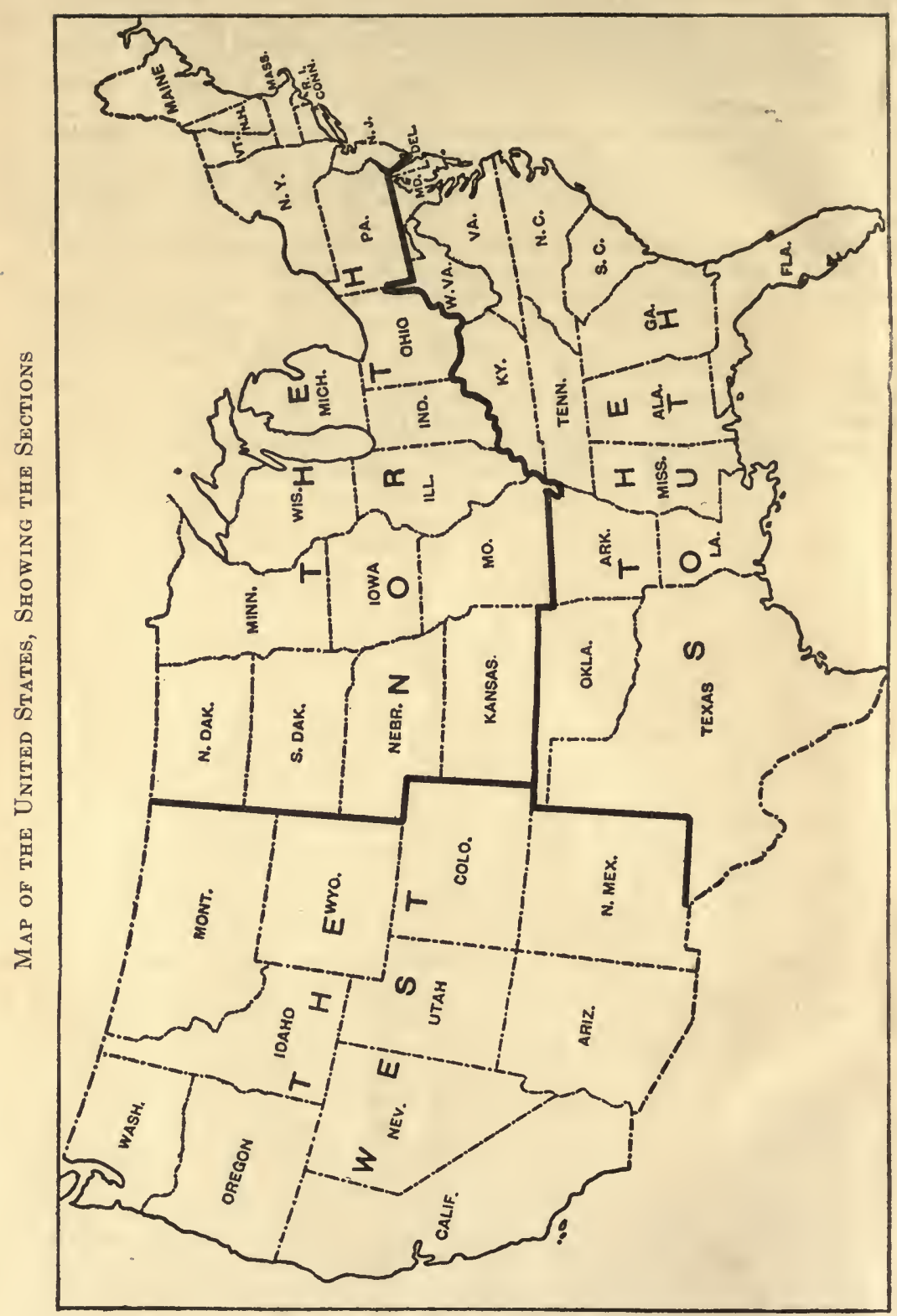




\title{
THE NEGRO FARMER IN THE UNITED STATES
}

\author{
By Charles E. Hall
}

Introduction

Due largely to the restriction of foreign immigration; to the call of industry for additional labor during the period of the World War and since; to the widespread ravages of the boll weevil; to a low and unstable cotton market, and possibly to other causes not properly withing the scope of this study, a decided shifting of the Negro rural-farm and rural-nonfarm population to the urban industrial centers of the South, North, and West has been in progress for nearly two decades, as indicated by the Fifteenth Decennial Census returns and the comparative figures for prior censuses. This change from an agricultural to an industrial environment, while resulting in a reduction in the number of Negro farmers, in the acreage under cultivation, and in relieving to a considerable extent an overcrowded agricultural labor condition in some of the States, has on the other hand contributed a few aggravating social problems to the highly organized industrial centers; problems that apparently are gradually growing less acute each year.

Of particular concern, it is believed, is the effect this migratory movement has had upon the agricultural status of the Negro race as a whole, and possibly upon agriculture as an industry; and it is to a brief presentation of agricultural rather than industrial or social statistics that this monograph is confined. Constituting 9.7 per cent of the total population of the United States in 1930; inhabiting 92.1 per cent of all the counties; carrying on as farm operators either as owners, managers, or tenants in every State and in 68.4 per cent of the counties; and forming 15.5 per cent of the rural-farm population, the farming activities of the Negro are generally listed as an asset to the agricultural resources and wealth of the Nation.

Negroes and Indians constitute the only racial groups that are still 50 per cent or more rural; however, if the present trend continues, Negroes will soon become largely urban. Only 42 years ago, at the census of 1890 , slightly in excess of 80 per cent (80.2) of the Negro population was rural. In 1900 this rural percentage had fallen to 77.3 ; in 1910 to 72.7 ; in 1920 to 66 ; and in 1930 to 56.3 per cent, as compared with 40.3 per cent rural population for the whites. The Negro ruralfarm ${ }^{1}$ population which is exclusive of the rural-nonfarm ${ }^{2}$ population fell from 48.7 per cent of the total Negro population in 1920 to 39.4 per cent in 1930 , while the rural-farm white population dropped from 27.5 of the total white population in 1920 to 22.9 per cent in 1930 . But quite significant is the fact that although there was a distinct loss in both Negro and white rural-farm population as well as in the number of farmers in each racial group the land operated by Negroes decreased by 3,835,050 acres, approximately 5,992 square miles, an area slightly larger than the combined land areas of Connecticut and Rhode Island, as compared with a very substantial increase of $34,743,840$ acres, or approximately 54,287 square miles for the white farm operators. The decrease in farm acreage operated by Negroes was mostly in the South, where there

1 The rural farm population as shown for 1930 comprises all persons living on farms in incorporated places of less than 2,500 inhabitants and in territory outside of incorporated places.

-The rural-nonfarm population, sometimes termed the "village" population, includes, in general, all persons living outside cities or other incorporated places having 2,500 inhabitants or more who do not live on farms. 
was also a decrease in the acreage operated by white farmers, though less marked than that for Negroes.

The extent to which this decrease in the Negro rural-farm population and in the number of farm operators has affected the participation of the Negro in agriculture in the North, the South, the West and in individual States is clearly indicated in the following tables which principally cover the decade 1920 to 1930 , but also include several tables covering the 20 years from 1910 to 1930 , the period of the greatest migration of Negroes from the rural-farm to the urban districts. The term "colored" is used to include Negroes, Indians, Chinese, Japanese and other nonwhite races. Figures for "colored" are given only where separate figures for Negroes are not available.

The 1930 census was taken as of April 1, 1930; the census of 1920 as of January 1, and the census of 1910 as of April 15. These changes in the dates of enumeration have affected somewhat the comparability of the statistics. 


\section{SUMMARY}

The statistics within, although but a brief presentation of the major activities of Negroes in agriculture, conclusively show that as farm owners, tenants, and managers they constitute an appreciable but diminishing national asset. The 1930 data indicate that while Negro farmers like those of most racial groups materially decreased in number during the decade 1920 to 1930, their operations have been extended to every State and to more than two-thirds of the 3,100 counties, many of which, however, are not adapted to agriculture. The figures further show that 20 years (1910 to 1930) of migration from the rural districts, particularly of the South, has not increased the number of Negro farmers in the North; has reduced the number in the South and increased only to a small extent the number in the West, and that as a result of present trends the census of 1920 will for years to come, if not permanently, stand out as the peak year for Negro farmers in the United States. As reported at that census there were 925,708 farmers operating 41,432,182 acres, with land and buildings valued at $\$ 2,257,645,325$, and a 23.6 per cent ownership consisting of 218,612 farms with 13,948,512 acres.

Possibly the most significant impairment was the acreage losses of Negro farm owners during the 10 years 1920 to 1930 . The loss of owned land $(2,749,619$ acres) was equivalent to 4,296 square miles, or an area more than twice the size of the State of Delaware, a reduction in acreage to which farm owners in all States except Arizona, Delaware, District of Columbia, Nevada, New Mexico, New York, Vermont, and Wyoming contributed. Due to the fact, however, that slightly in excess of 28 per cent of the owners in the South are under 45 years of age, and 57 per cent under 55, and that in the selected Northern States approximately 21 per cent are under 45 , and nearly 46 per cent are under 55 years of age, an expansion of acreage in Negro-owned farms and also an increase in the number of owners is a possibility, under favorable agricultural credit conditions accompanied by a restoration of higher market values for farm products, Negro owners being less inclined than tenants to respond to the call of industry for wage-workers. In this connection, it is also worthy of note that only 29.9 per cent of the colored fully owned farms in the South were mortgaged, as compared with 39.8 , per cent of those operated by all racial groups throughout the United States, as a whole.

From the 1930 figures showing the distribution of automobiles on farms in the South, it is apparent that there was not a disproportionate number reported by colored operators in that territory. Taking the South as a whole, the average was 4.7 colored farmers, as compared with 2 white farmers per automobile on the farms reported by each group. In six States-Georgia, Florida, Mississippi, Louisiana, Arkansas, and Alabama-the averages ranged from 5.2 to 7.5 colored farmers per automobile, while the highest average for white farmers was in Arkansas with 3 farmers per automobile. With the distribution based on farm ownership in the South it appears that there were 4,499 more automobiles than colored farm owners, all of whom were Negroes, except 5,889 , while among white farmers there were 66,837 more farm owners than automobiles.

The decrease in the number of alien nonwhite farmers, and the increase in the number of Negro farmers in the extreme West may or may not be significant of their future expansion in that territory. 


\section{TEXT AND TABLES}

Negro population.-At the census of 1930, as shown in Table 1 , there were $11,891,143$ Negro inhabitants in the United States which represented an increase of $1,428,012$, or 13.6 per cent between January 1, 1920, and April 1, 1930. This element of the population constitutes 9.7 per cent of the total population in 1930 as compared with 9.9 per cent in 1920. Divided into geographic sections, $2,409,219$, or 20.3 per cent were in the North as compared with 14.1 per cent in $1920 ; 9,361,577$, or 78.7 per cent as compared with 85.2 per cent in 1920 were in the South; and 120,347 , or 1 per cent as compared with less than 1 per cent in 1920 were in the West. During the 10 years the Negro population in the North increased at the rate of 63.6 per cent; the South showed an increase of 5 per cent, and the West an increase of 53.1 per cent.

Table 1.-Total Negro Population, with Percentages, by Sections: 1930 AND 1920

\begin{tabular}{|c|c|c|c|c|}
\hline \multirow{2}{*}{ SECTION } & \multirow{2}{*}{1930} & \multirow{2}{*}{1920} & \multicolumn{2}{|c|}{ INCREASE, 1920-1930 } \\
\hline & & & Number & Per cent \\
\hline United States_...... & $11,891,143$ & $10,463,131$ & $1,428,012$ & 13. 8 \\
\hline \multirow[t]{3}{*}{$\begin{array}{l}\text { The South } \\
\text { The North } \\
\text { The West. }\end{array}$} & $\begin{array}{r}9,361,577 \\
2,409,219 \\
120,347\end{array}$ & $\begin{array}{r}8,912,231 \\
1,472,309 \\
78,591\end{array}$ & $\begin{array}{r}449,346 \\
936,910 \\
41,756\end{array}$ & $\begin{array}{r}5.0 \\
63.6 \\
53.1\end{array}$ \\
\hline & \multicolumn{4}{|c|}{ PER CENT DISTRIBUTION } \\
\hline & 100.0 & 100.0 & 100.0 & \\
\hline $\begin{array}{l}\text { The South } \\
\text { The North } \\
\text { The West }\end{array}$ & $\begin{array}{r}78.7 \\
20.3 \\
1.0\end{array}$ & $\begin{array}{r}85.2 \\
14.1 \\
0.8\end{array}$ & $\begin{array}{r}31.5 \\
65.6 \\
2.9\end{array}$ & 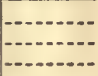 \\
\hline
\end{tabular}

Negro rural population.-Table 2 is introduced to show for the United States, by sections, the number of Negro inhabitants living in rural areas and incorporated places having less than 2,500 inhabitants; and especially to show the Negro rural-farm population for which a decrease of 419,440 , or 8.2 per cent was reported for the 10 years. This decrease is attributed wholly to the South where there were 425,557 less Negroes on farms than 10 years previous. In the North there was an increase of 3,736 , and in the West, 2,381 in the Negro rural-farm population. Negro inhabitants of the rural-nonfarm communities increased 213,012 , or 11.8 per cent; the North reporting an increase of 34.4 per cent; the South 9.8 per cent; while the West reported a decrease of 10.2 per cent. Taking the Negro rural population as a whole (rural-farm, and rural-nonfarm) there was a decrease of 206,428 , or 3 per cent during the 10 years. The South showed a loss of 266,010; the North an increase of 58,893 , and the West a net gain of 689 due to the increase of the Negro rural-farm population. 
Table 2.-Negro Rural Population, by Sections: 1930 and 1920

[A minus sign $(-$ ) denotes decrease]

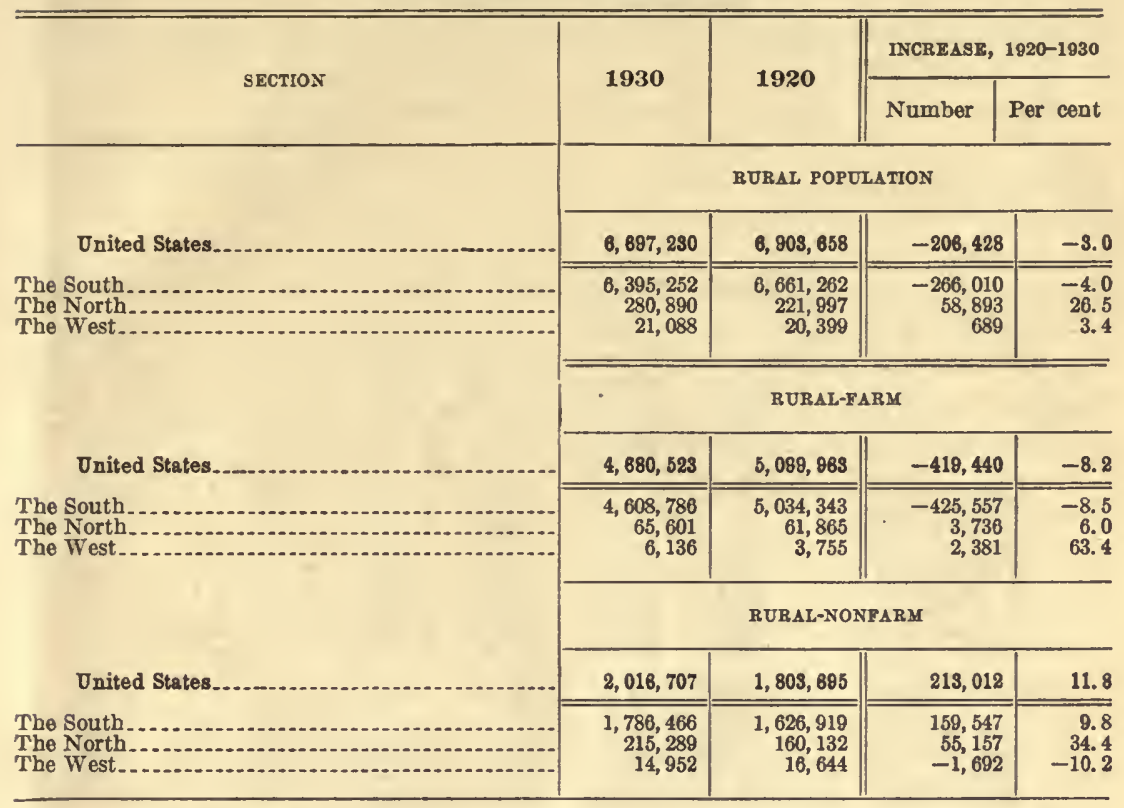

Results of migration. ${ }^{1-T h e ~ y e a r s ~ b e t w e e n ~} 1910$ and 1930, as shown in Table 3 , cover the time during which the migratory movement of the Negro population reached its greatest height since the Civil War period. During these 20 years with very small accretions from other countries the natural growth of the negro population in the United States as a whole was 21 per cent; the Negro urban population increased by 93.5 per cent, while the rural decreased by 6.2 per cent. Dividing the country into sections, the South showed a net gain of 612,150 Negro inhabitants, having lost 499,720 in the rural sections and gained $1,111,870$ in the urban communities. The North reported both rural and urban increases to the number of 1,381,545 Negro inhabitants. In the West there was also an increase of both rural and urban Negro inhabitants, principally in California. In this section, which comprises the States constituting the Mountain and Pacific divisions, an increase of 10,234 was reported for the rural areas and one of 59,451 for the urban centers.

Some of the results of these 20-year losses and gains in the rural population are reflected in the farm operations of the Negro inhabitants, as shown in Tables 20 to 22 .

\footnotetext{
1 See paper "Recent Northward Migration of the Negro" by Dr. Joseph A. Hill, read before the American Sociological Society, Washington, D. C., Dec. 27,1923 , and reprinted from the Monthly Labor Review (March, 1924) of the Bureau of Labor Statistics, United States Department of Labor.
}

$$
130058-33-2
$$


Table 3.-Negro Rural and Urban Popdlation, by Sections, Divisions, AND STATES: 1930 AND 1910

[A minus sign (-) denotes decrease]

\begin{tabular}{|c|c|c|c|c|c|c|c|c|}
\hline \multirow{4}{*}{ SECTION, DIVISION, AND STATE } & \multicolumn{8}{|c|}{ NEGRO POPULATION } \\
\hline & \multirow{2}{*}{\multicolumn{2}{|c|}{ Rural }} & \multirow{2}{*}{\multicolumn{2}{|c|}{ Urban }} & \multicolumn{4}{|c|}{ Increase, 1910-1930 } \\
\hline & & & & & \multicolumn{2}{|c|}{ Rural } & \multicolumn{2}{|c|}{ Urban } \\
\hline & 1930 & 1910 & 1930 & 1910 & Number & $\begin{array}{l}\text { Per } \\
\text { cent }\end{array}$ & Number & $\begin{array}{l}\text { Per } \\
\text { cent }\end{array}$ \\
\hline United States. & $6,697,230$ & $7,142,966$ & $5,183,913$ & $2,684,797$ & $-445,736$ & -6.2 & $2,509,116$ & 93.5 \\
\hline The South.... & $6,395,252$ & $6,894,972$ & $2,966,325$ & $1,854,455$ & $-499,720$ & -7.2 & $1,111,870$ & 60.0 \\
\hline South Atlantic_. & $2,958,484$ & $3,202,968$ & $1,462,904$ & 909,520 & $-244,484$ & -7.6 & 553,384 & 60.8 \\
\hline 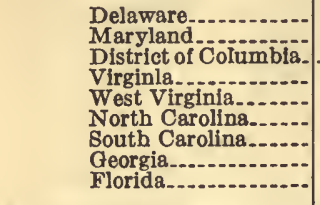 & \begin{tabular}{r}
17,565 \\
116,725 \\
\hdashline 36,764 \\
83,669 \\
672,410 \\
655,327 \\
754,488 \\
221,536
\end{tabular} & $\begin{array}{r}20,024 \\
133,020 \\
-512,878 \\
48,793 \\
581,868 \\
734,141 \\
952,161 \\
220,083\end{array}$ & $\begin{array}{r}15,037 \\
159,654 \\
132,068 \\
213,401 \\
31,224 \\
246,237 \\
138,354 \\
316,637 \\
210,292\end{array}$ & $\begin{array}{r}11,157 \\
99,230 \\
94,446 \\
158,218 \\
15,380 \\
115,975 \\
101,702 \\
224,826 \\
88,586\end{array}$ & \begin{tabular}{r}
$-2,459$ \\
$-16,295$ \\
\hdashline$-76,114$ \\
34,876 \\
90,542 \\
$-78,814$ \\
$-197,673$ \\
1,453
\end{tabular} & $\begin{array}{r}-12.3 \\
-12.3 \\
-14.8 \\
71.5 \\
15.6 \\
-10.7 \\
-20.8 \\
0.7\end{array}$ & $\begin{array}{r}3,880 \\
60,424 \\
37,622 \\
55,183 \\
15,844 \\
130,262 \\
36,652 \\
91,811 \\
121,706\end{array}$ & $\begin{array}{r}34.8 \\
60.9 \\
39.8 \\
34.9 \\
103.0 \\
112.3 \\
36.0 \\
40.8 \\
137.4\end{array}$ \\
\hline East South Centra & $1,899,072$ & $2,143,416$ & $\mathbf{7 5 9}, \mathbf{1 6 6}$ & 509,097 & $-244,344$ & -11.4 & 250,069 & 49.1 \\
\hline $\begin{array}{l}\text { Kentucky } \\
\text { Tennessee } \\
\text { Alabama. } \\
\text { Mississippi. }\end{array}$ & $\begin{array}{l}109,479 \\
237,478 \\
676,384 \\
875,731\end{array}$ & $\begin{array}{l}155,025 \\
322,582 \\
751,679 \\
914,130\end{array}$ & $\begin{array}{l}116,561 \\
240,168 \\
268,450 \\
133,987\end{array}$ & $\begin{array}{r}106,631 \\
150,506 \\
156,603 \\
95,357\end{array}$ & $\begin{array}{l}-45,546 \\
-85,104 \\
-75,295 \\
-38,399\end{array}$ & $\begin{array}{l}-29.4 \\
-26.4 \\
-10.0 \\
-4.2\end{array}$ & $\begin{array}{r}9,930 \\
89,662 \\
111,847 \\
38,630\end{array}$ & $\begin{array}{r}9.3 \\
59.6 \\
71.4 \\
40.5\end{array}$ \\
\hline West South Centr & $1,537,696$ & $1,548,588$ & 744,255 & 435,838 & $-10,892$ & -0.7 & 308,417 & 70.8 \\
\hline $\begin{array}{l}\text { Arkansas..... } \\
\text { Louisiana.... } \\
\text { Oklahoma... } \\
\text { Texas...-.... }\end{array}$ & $\begin{array}{l}389,301 \\
518,863 \\
104,397 \\
525,135\end{array}$ & $\begin{array}{l}\mathbf{3 8 3}, \mathbf{7 4 4} \\
\mathbf{5 5 3}, 029 \\
\mathbf{1 0 0}, 630 \\
\mathbf{5 1 1}, \mathbf{1 8 5}\end{array}$ & $\begin{array}{r}89,162 \\
257,463 \\
67,801 \\
329,829\end{array}$ & $\begin{array}{r}59,147 \\
160,845 \\
36,982 \\
178,864\end{array}$ & $\begin{array}{r}5,557 \\
-34,166 \\
3,767 \\
13,950\end{array}$ & $\begin{array}{r}1.4 \\
-6.2 \\
3.7 \\
2.7\end{array}$ & $\begin{array}{r}30,015 \\
96,618 \\
30,819 \\
150,965\end{array}$ & $\begin{array}{l}50.7 \\
60.1 \\
83.3 \\
84.4\end{array}$ \\
\hline The North............ & 280,890 & 237,140 & $2,128,329$ & 790,534 & 43,750 & 18.4 & $1,337,795$ & 169.2 \\
\hline New England........ & 12,643 & 9,861 & 81,443 & 56,445 & 2,782 & 28.2 & 24,998 & 44.3 \\
\hline $\begin{array}{l}\text { Maine } \\
\text { New Hampshire..... } \\
\text { Mermont } \\
\text { Massachusetts....... } \\
\text { Connecticut......... }\end{array}$ & $\begin{array}{r}393 \\
196 \\
355 \\
6,042 \\
834 \\
4,823\end{array}$ & $\begin{array}{r}571 \\
208 \\
1,295 \\
2,812 \\
474 \\
4,501\end{array}$ & $\begin{array}{r}703 \\
594 \\
213 \\
46,323 \\
9,079 \\
24,531\end{array}$ & $\begin{array}{r}792 \\
356 \\
326 \\
35,243 \\
9,055 \\
10,673\end{array}$ & $\begin{array}{r}-178 \\
-12 \\
-940 \\
3,230 \\
360 \\
322\end{array}$ & $\begin{array}{r}-31.2 \\
-5.8 \\
-72.6 \\
114.9 \\
75.9 \\
7.2\end{array}$ & $\begin{array}{r}-89 \\
238 \\
-113 \\
11,080 \\
24 \\
13,858\end{array}$ & $\begin{array}{r}-11.2 \\
66.9 \\
-34.7 \\
31.4 \\
0.3 \\
129.8\end{array}$ \\
\hline Middle Atlantic-- & 113,835 & 78,624 & 939,064 & 339,246 & 35,211 & 44.8 & 599,818 & 176.8 \\
\hline $\begin{array}{l}\text { New York } \\
\text { New Jersey.......... } \\
\text { Pennsylvania... }\end{array}$ & $\begin{array}{l}22,315 \\
33,843 \\
57,677\end{array}$ & $\begin{array}{l}16,705 \\
24,333 \\
37,586\end{array}$ & $\begin{array}{l}390,499 \\
174,985 \\
373,580\end{array}$ & $\begin{array}{r}117,486 \\
65,427 \\
156,333\end{array}$ & $\begin{array}{r}5,610 \\
9,510 \\
20,091\end{array}$ & $\begin{array}{l}33.6 \\
39.1 \\
53.5\end{array}$ & $\begin{array}{l}273,013 \\
109,558 \\
217,247\end{array}$ & $\begin{array}{l}232.4 \\
167.5 \\
139.0\end{array}$ \\
\hline East North Central. & 81,823 & 70,294 & 848,627 & 230,542 & 11,529 & 16.4 & 618,085 & 268.1 \\
\hline $\begin{array}{l}\text { Ohio } \\
\text { Indiana.... } \\
\text { Illinois._. } \\
\text { Michigan } \\
\text { Wisconsin. }\end{array}$ & $\begin{array}{r}37,332 \\
8,940 \\
24,936 \\
9,749 \\
866\end{array}$ & $\begin{array}{r}29,170 \\
11,895 \\
23,511 \\
4,959 \\
759\end{array}$ & \begin{tabular}{rl|}
271,972 \\
103,042 \\
304,036 \\
159,704 \\
9,873
\end{tabular} & $\begin{array}{r}82,282 \\
48,425 \\
85,538 \\
12,156 \\
2,141\end{array}$ & $\begin{array}{r}8,162 \\
-2,955 \\
1,425 \\
4,790 \\
107\end{array}$ & $\begin{array}{r}28.0 \\
-24.8 \\
6.1 \\
96.6 \\
14.1\end{array}$ & $\begin{array}{r}189,690 \\
54,617 \\
218,498 \\
147,548 \\
7,732\end{array}$ & $\begin{array}{r}230.5 \\
112.8 \\
255.4 \\
1,213.8 \\
361.1\end{array}$ \\
\hline West North Central...... & 72,589 & 78,361 & 259,195 & 164,301 & $-5,772$ & -7.4 & 94,894 & 57.8 \\
\hline 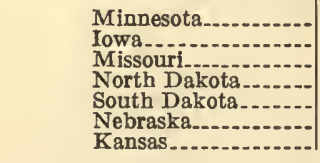 & $\begin{array}{r}335 \\
2,195 \\
53,886 \\
161 \\
309 \\
640 \\
15,063\end{array}$ & $\begin{array}{r}566 \\
5,187 \\
52,990 \\
311 \\
405 \\
1,068 \\
17,834\end{array}$ & $\begin{array}{r}9,110 \\
15,185 \\
169,954 \\
216 \\
337 \\
13,112 \\
51,281\end{array}$ & \begin{tabular}{r|}
6,518 \\
9,786 \\
104,462 \\
306 \\
412 \\
6,621 \\
36,196
\end{tabular} & $\begin{array}{r}-231 \\
-2,992 \\
896 \\
-150 \\
-96 \\
-428 \\
-2,771\end{array}$ & $\begin{array}{r}-40.8 \\
-57.7 \\
1.7 \\
-48.2 \\
-23.7 \\
-40.1 \\
-15.5\end{array}$ & $\begin{array}{r}2,592 \\
5,399 \\
65,492 \\
-90 \\
-75 \\
6,491 \\
15,085\end{array}$ & $\begin{array}{r}39.8 \\
55.2 \\
62.7 \\
-29.4 \\
-18.2 \\
98.0 \\
41.7\end{array}$ \\
\hline
\end{tabular}


Table 3.-Negro Rural and Urban Population, by Sections, Divisions, AND States: 1930 and 1910 -Continued

\begin{tabular}{|c|c|c|c|c|c|c|c|c|}
\hline \multirow{4}{*}{ SECTION, DIVISION, AND STATE } & \multicolumn{8}{|c|}{ NEGRO POPULATION } \\
\hline & \multirow{2}{*}{\multicolumn{2}{|c|}{ Rural }} & \multirow{2}{*}{\multicolumn{2}{|c|}{ Urban }} & \multicolumn{4}{|c|}{ Increase, $1910-1930$} \\
\hline & & & & & \multicolumn{2}{|c|}{ Rural } & \multicolumn{2}{|c|}{ Urban } \\
\hline & 1930 & 1910 & 1930 & 1910 & Number & $\begin{array}{l}\text { Per } \\
\text { cent }\end{array}$ & Number & $\begin{array}{l}\text { Per } \\
\text { cent }\end{array}$ \\
\hline The West...... & 21.088 & 10.854 & 99,259 & 39.808 & 10.234 & 94.8 & 59.451 & 148.3 \\
\hline Mountain.......... & 9,193 & 6,021 & 21,032 & 15,446 & 3,172 & 52.7 & 5,586 & 36.2 \\
\hline 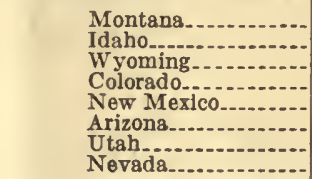 & $\begin{array}{r}229 \\
166 \\
391 \\
1,357 \\
1,132 \\
5,602 \\
164 \\
152\end{array}$ & $\begin{array}{r}379 \\
225 \\
1,194 \\
2,094 \\
833 \\
699 \\
185 \\
412\end{array}$ & $\begin{array}{r}1,027 \\
502 \\
859 \\
10,471 \\
1,718 \\
5,147 \\
944 \\
364\end{array}$ & $\begin{array}{r}1,455 \\
426 \\
1,041 \\
9,359 \\
795 \\
1,310 \\
959 \\
101\end{array}$ & $\begin{array}{r}-150 \\
-59 \\
-803 \\
-737 \\
299 \\
4,903 \\
-21 \\
-260\end{array}$ & $\begin{array}{r}-39.6 \\
-26.2 \\
-67.3 \\
-3.2 \\
35.9 \\
701.4 \\
-11.4 \\
-63.1\end{array}$ & $\begin{array}{r}-428 \\
76 \\
-182 \\
1,112 \\
923 \\
3,837 \\
-15 \\
263\end{array}$ & $\begin{array}{r}-29.4 \\
17.8 \\
-17.5 \\
11.8 \\
116.1 \\
292.8 \\
-1.6 \\
260.4\end{array}$ \\
\hline Pacific...... & 11,895 & 4,833 & 78,227 & 24,362 & 7,062 & 146.1 & 53,865 & 221.1 \\
\hline $\begin{array}{l}\text { Washington. } \\
\text { Oregon } \\
\text { California }\end{array}$ & $\begin{array}{r}1,022 \\
344 \\
10,529\end{array}$ & $\begin{array}{r}1,359 \\
228 \\
3,246\end{array}$ & $\begin{array}{r}5,818 \\
1,890 \\
70,519\end{array}$ & $\begin{array}{r}4,699 \\
1,264 \\
18,399\end{array}$ & $\begin{array}{r}-337 \\
116 \\
7,283\end{array}$ & $\begin{array}{r}-24.8 \\
50.9 \\
224.4\end{array}$ & $\begin{array}{r}1,119 \\
626 \\
52,120\end{array}$ & $\begin{array}{r}23.8 \\
49.5 \\
283.3\end{array}$ \\
\hline
\end{tabular}

Racial class.-Table 4 summarizes the figures for the total population and farm operators of the United States by color or race for 1920 and 1930 . Negroes constituted 9.7 per cent of the total population and 14 per cent of the farm operators in 1930 as compared with a 9.9 per cent population and a 14.4 per cent farm operator proportion in 1920 while the white population showed increases of one-tenth of 1 per cent both in the proportion of their total population and farm operators. All of the other racial classes combined did not contribute as much as 1 per cent to the total number of inhabitants or farm operators either in 1920 or 1930.

Table 4.-Population and Farm Operators by Racial Classes: 1930 AND 1920

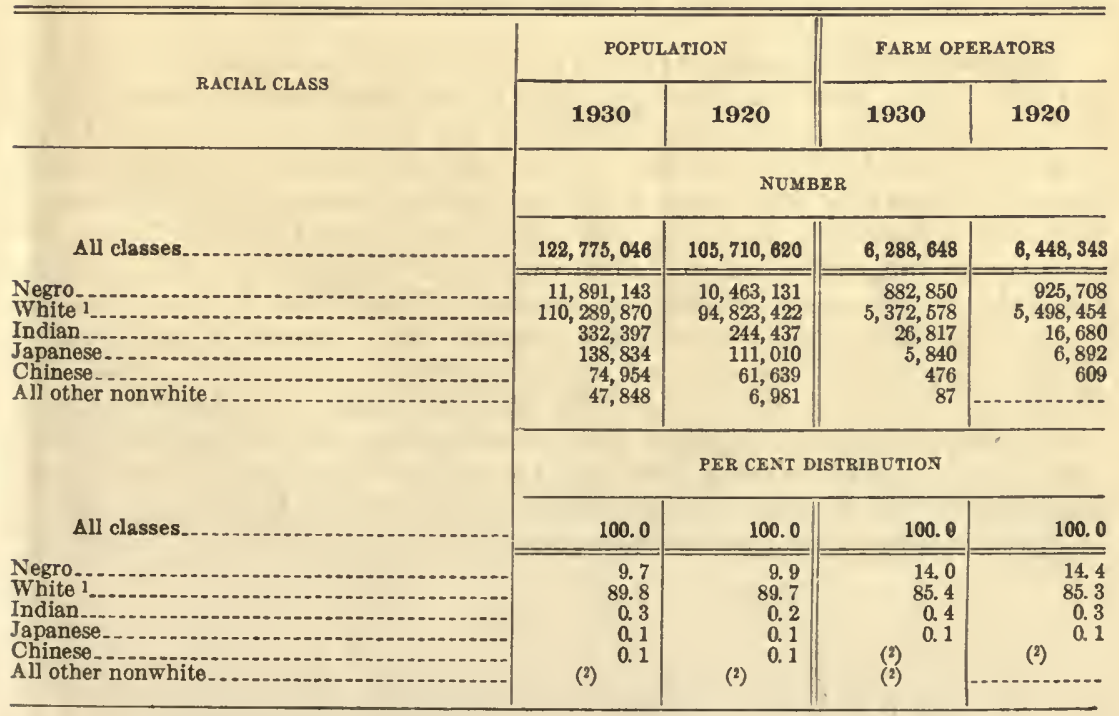


Increase by racial class. - Table 5 shows an increased population of $17,064,426$, but a decrease of 159,695 in the number of farm operators between 1920 and 1930 . There was a loss of 125,876 white farmers whose ratio dropped from 58 to 49 operators per 1,000 white inhabitants during the 10-year period. Negro farmers decreased 42,858 , or from 88 operators in 1920 per 1,000 Negro inhabitants to 74 in 1930. Japanese and Chinese farmers also decreased in number, while the Indian farmers increased by 10,137 , or from 68 to 81 farm operators per 1,000 Indian inhabitants from 1920 to 1930 .

The increase in the number of farms operated by Indians is due mainly to a change in the method of enumerating the farming operations on Indian reservations. In 1930 special efforts were made to obtain a schedule for each individual Indian engaged in agriculture, while in 1920 many reservation groups were enumerated as single farms. The figures shown in Tables 4 and 5 , therefore, do not necessarily represent radical changes in the number of Indians actually engaged in farming.

Table 5.-Increase in Population and Number of Farm Operators, 1920 to 1930, by Racial Classes; and Number of Operators Per 1,000 Population of Each Class: 1930 and 1920

[A minus sign $(-)$ denotes decrease]

\begin{tabular}{|c|c|c|c|c|c|c|}
\hline \multirow{3}{*}{ RACIAL CLASS } & \multicolumn{4}{|c|}{ INCREASE, 1920-1930 } & \multirow{2}{*}{\multicolumn{2}{|c|}{$\begin{array}{l}\text { FARM OPERA- } \\
\text { TORS PER } 1,000 \\
\text { POPULATION OF } \\
\text { EACH CLASS }\end{array}$}} \\
\hline & \multicolumn{2}{|c|}{ Number } & \multicolumn{2}{|c|}{ Per cent } & & \\
\hline & Population & $\begin{array}{c}\text { Farm } \\
\text { operators }\end{array}$ & $\begin{array}{l}\text { Popula- } \\
\text { tion }\end{array}$ & $\begin{array}{c}\text { Farm } \\
\text { operators }\end{array}$ & 1930 & 1920 \\
\hline All classes... & $17,064,426$ & $-159,695$ & 16.1 & -2.5 & 61 & 61 \\
\hline $\begin{array}{l}\text { Negro. } \\
\text { White } \\
\text { Indian } \\
\text { Japanese } \\
\text { Chinese } \\
\text { All other nonwhite. }\end{array}$ & $\begin{array}{r}1,428,012 \\
15,466,448 \\
87,960 \\
27,824 \\
13,315 \\
40,867\end{array}$ & $\begin{array}{r}-42,858 \\
-125,876 \\
10,137 \\
-1,052 \\
-133 \\
87\end{array}$ & $\begin{array}{r}13.6 \\
16.3 \\
36.0 \\
25.1 \\
21.6 \\
585.4\end{array}$ & $\begin{array}{r}-4.6 \\
-2.3 \\
60.8 \\
-15.3 \\
-21.8 \\
\end{array}$ & $\begin{array}{r}74 \\
49 \\
81 \\
42 \\
6 \\
2\end{array}$ & $\begin{array}{l}88 \\
58 \\
68 \\
62 \\
10\end{array}$ \\
\hline
\end{tabular}

Negro farmers by counties. - Table 6 shows the number of counties by States, and the number reporting Negro inhabitants and Negro farm operators at the census of 1930. There are Negro inhabitants and Negro farmers in every State. Slightly in excess of 92 per cent (92.1) of the 3,100 counties reported Negro inhabitants, and more than 68 per cent (68.4) reported Negro farmers. In five StatesConnecticut, Delaware, Louisiana, Mississippi, and South Carolina-Negro farmers operated in every county. Alabama, North Carolina, and Rhode Island reported 1 county each in which there were none; Florida and Maryland, 2 each; Georgia, Massachusetts, New Jersey, Tennessee, and Vermont, 3 each; while 5 each were reported for Arizona and New Hampshire; 6 for Kentucky, Ohio, and Oklahoma; and 8 for Maine. All other States reported more than 10 counties each in which there were no Negro farmers, the number of counties ranging from 12 in Arkansas to 65 in Texas with its 254 counties. The State of Utah with 29 counties, only two of which reported Negro farmers, has the lowest percentage of counties showing farmers of this racial class. 


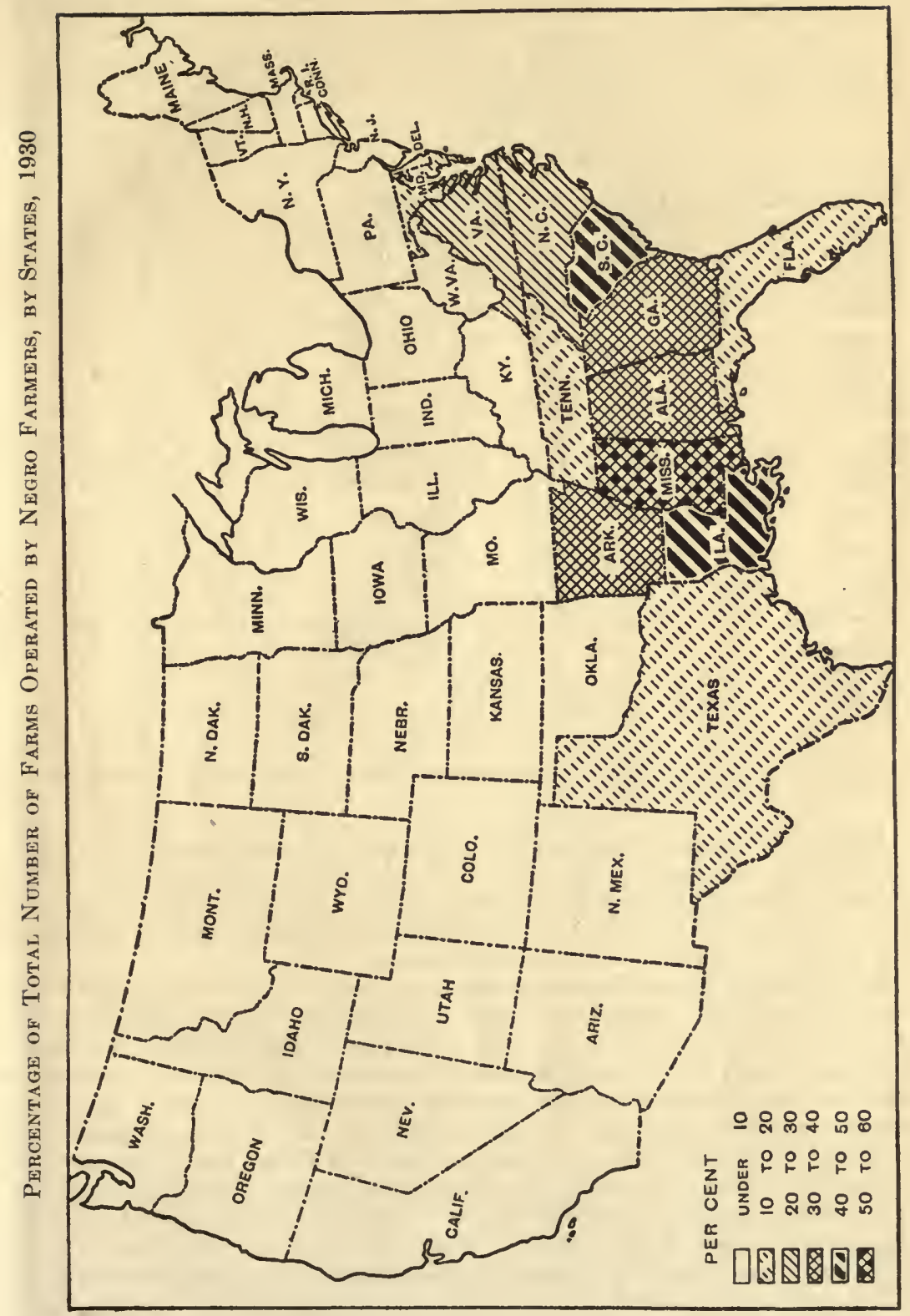


Table 6. - Number of Counties in Each State Reporting Negro Inhabitants and Negro Farmers, 1930

\begin{tabular}{|c|c|c|c|c|c|c|c|}
\hline \multirow[b]{2}{*}{ STATE } & \multicolumn{3}{|c|}{ NLMBER OF COUNTIES } & \multirow[b]{2}{*}{ STATE } & \multicolumn{3}{|c|}{ NUMBER OF COUNTIES } \\
\hline & Total & $\begin{array}{l}\text { Re- } \\
\text { port- } \\
\text { ing Ne- } \\
\text { gro in- } \\
\text { habit- } \\
\text { ants }\end{array}$ & $\begin{array}{l}\text { Re- } \\
\text { port- } \\
\text { ing Ne- } \\
\text { gro } \\
\text { farm- } \\
\text { ers }\end{array}$ & & Total & $\begin{array}{l}\text { Re- } \\
\text { port- } \\
\text { ing Ne- } \\
\text { gro in- } \\
\text { habit- } \\
\text { ants }\end{array}$ & $\begin{array}{l}\text { Re- } \\
\text { port- } \\
\text { ing Ne- } \\
\text { gro } \\
\text { farm- } \\
\text { ers }\end{array}$ \\
\hline Onited States. & 13,100 & 2,855 & 2,119 & Nebraska.. & 93 & 65 & 21 \\
\hline Alabama & 67 & 67 & 66 & $\begin{array}{l}\text { Nevada } \\
\text { New Hampshire. }\end{array}$ & $\begin{array}{l}17 \\
10\end{array}$ & $\begin{array}{l}15 \\
10\end{array}$ & $\begin{array}{l}3 \\
5\end{array}$ \\
\hline Arizona.... & 14 & 13 & 9 & New Jersey...... & 21 & 21 & 18 \\
\hline Arkansas_. - & 75 & 72 & 63 & New Mexico........ & 31 & 28 & 9 \\
\hline $\begin{array}{l}\text { California... } \\
\text { Colorado }\end{array}$ & $\begin{array}{l}58 \\
63\end{array}$ & $\begin{array}{l}57 \\
54\end{array}$ & 36 & New York & 62 & 62 & 44 \\
\hline Connecticut. & 8 & 8 & 8 & North Carolina. & $\begin{array}{r}100 \\
53\end{array}$ & $\begin{array}{r}100 \\
33\end{array}$ & $\begin{array}{l}99 \\
10\end{array}$ \\
\hline Delaware & 3 & 3 & 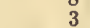 & Ohio.......... & 88 & 87 & $\begin{array}{l}10 \\
82\end{array}$ \\
\hline District of Columbia. & 1 & 1 & 1 & Oklahoma... & 77 & 73 & 71 \\
\hline Florida & 67 & 67 & 65 & & & & \\
\hline Georgia... & 161 & 160 & 158 & Oregon & 36 & 32 & 6 \\
\hline Idaho.... & 44 & 30 & $\theta$ & Rhode Island...- & 5 & $\begin{array}{r}60 \\
5\end{array}$ & $\begin{array}{r}44 \\
4\end{array}$ \\
\hline Illinois... & 102 & 96 & 60 & South Carolina & 46 & 46 & 46 \\
\hline Indiana... & 92 & 86 & 60 & South Dakota........... & 69 & 45 & 23 \\
\hline Iowa & 99 & 87 & 32 & & & & \\
\hline Kansas ..... & 105 & 99 & 78 & Tennessee... & 95 & 95 & 92 \\
\hline Kentucky . & 120 & 120 & 114 & $\begin{array}{l}\text { Texas......... } \\
\text { Utah........ }\end{array}$ & $\begin{array}{r}254 \\
29\end{array}$ & $\begin{array}{r}243 \\
13\end{array}$ & $\begin{array}{r}189 \\
2\end{array}$ \\
\hline Louisiana............ & 64 & 64 & 64 & Vermont..... & 14 & 13 & H \\
\hline $\begin{array}{l}\text { Maine } \\
\text { Maryland }\end{array}$ & 16 & 16 & 8 & Virginia............ & 124 & 124 & 106 \\
\hline $\begin{array}{l}\text { Maryland } \\
\text { Massachusetts }\end{array}$ & $\begin{array}{l}24 \\
14\end{array}$ & $\begin{array}{l}24 \\
14\end{array}$ & $\begin{array}{l}22 \\
11\end{array}$ & Washlngton. & 39 & 33 & 20 \\
\hline Michigan & & & & $\begin{array}{l}\text { West Vlrginia } \\
\text { Wisconsin }\end{array}$ & 55 & $\begin{array}{l}54 \\
55\end{array}$ & $\begin{array}{l}39 \\
27\end{array}$ \\
\hline Minnesota & 87 & 71 & 18 & W yoming & 24 & 22 & 8 \\
\hline Mississippi.... & 82 & 82 & 82 & & & & \\
\hline Missouri & 115 & 103 & 83 & & & & \\
\hline Montana_....... & 56 & 45 & 14 & & & & \\
\hline
\end{tabular}

1 Includes Baltimore city. St. Louis city, 24 independent cities in Virginia, and that part of Yellowstone National Park located in Wyoming.

Sectional changes.-The distribution of Negro and white farmers by sections and southern geographic divisions for 1920 and 1930 is shown in Table 7. Although noteworthy changes in the total number of farmers in both groups have occurred during the 10 years, but slight differences in the per cent distribution by sections are indicated for the two census periods.

Of the 925,708 Negro farmers reported in 1920 only 10,113 , or 1.1 per cent lived outside of the South, as compared with 11,914, or 1.4 per cent in 1930. But while the number of Negro farmers decreased in the South and made slight gains in the North and West, white farmers increased in the South and West but decreased in the States forming the North. Of the 5,498,454 white farm operators reported at the 1920 census $2,283,750$, or 41.5 per cent were in the South, as compared with $2,342,129$, or 43.6 per cent at the census of 1930 . With less than 2 per cent (1.4) of the negro farmers living in the North and West, slightly more than 56 per cent (56.4) of the white farmers operate in the Northern and Western States. In the South the increases in the number of Negro farmers in the East South Central and West South Central divisions were insufficient to cover the decreases in the South Atlantic division which includes several States, notably Georgia, South Carolina, and Virginia, in which both Negro inhabitants and Negro farmers decreased greatly during the 10 years 1920 to 1930 . 
Table 7.-Number of Negro and White Farm Operators, by Sections and Southern Divisions: 1930 and 1920

\begin{tabular}{|c|c|c|c|c|}
\hline \multirow{4}{*}{ SECTION AND DIVISION } & \multicolumn{4}{|c|}{ FARM OPERATORS } \\
\hline & \multicolumn{2}{|c|}{ Negro } & \multicolumn{2}{|c|}{ White } \\
\hline & 1930 & 1920 & 1930 & 1920 \\
\hline & \multicolumn{4}{|c|}{ NUMBER } \\
\hline \multirow{3}{*}{$\begin{array}{l}\text { The South } \\
\text { South Atlantic } \\
\text { East South Central } \\
\text { West South Central } \\
\text { The North } \\
\text { The West.................. }\end{array}$} & 882,850 & 925,708 & $5,372,578$ & $5,498,454$ \\
\hline & $\begin{array}{r}870,936 \\
295,934 \\
320,600 \\
254,402 \\
11,104 \\
810\end{array}$ & $\begin{array}{r}915,595 \\
382,278 \\
307,006 \\
226,311 \\
9,380 \\
733\end{array}$ & $\begin{array}{r}2,342,129 \\
760,089 \\
741,255 \\
840,785 \\
2,545,829 \\
484,620\end{array}$ & $\begin{array}{r}2,283,750 \\
775,144 \\
744,368 \\
764,238 \\
2,750,203 \\
464,501\end{array}$ \\
\hline & \multicolumn{4}{|c|}{ PER CENT DISTRIBUTION } \\
\hline United States............. & 100.0 & 100.0 & 100.0 & 100.0 \\
\hline $\begin{array}{l}\text { The South } \\
\text { South Atlantic } \\
\text { East South Central } \\
\text { West South Central } \\
\text { The North.............. } \\
\text { The West. }\end{array}$ & $\begin{array}{r}98.7 \\
33.5 \\
36.3 \\
28.8 \\
1.3 \\
0.1\end{array}$ & $\begin{array}{r}98.9 \\
41.3 \\
33.2 \\
24.4 \\
1.0 \\
0.1\end{array}$ & $\begin{array}{r}43.6 \\
14.1 \\
13.8 \\
15.6 \\
47.4 \\
9.0\end{array}$ & $\begin{array}{r}41.5 \\
14.1 \\
13.5 \\
13.9 \\
50.0 \\
8.4\end{array}$ \\
\hline
\end{tabular}

Increases and decreases.-The extent of the increases and decreases in the number of Negro and white farm operators in the United States by sections and southern divisions, and the ratio of operators per 1,000 population of each are shown in Table 8. Between 1920 and 1930 Negro farmers decreased by 42,858, or at the rate of 4.6 per cent, as compared with a decrease of 125,876 , or 2.3 per cent for the white farmers. The ratio of Negro farmers per 1,000 Negro population fell from 88 in 1920 to 74 in 1930 as against a decrease from 58 in 1920 to 49 in 1930 in the ratio for the white farmers. The West South Central division comprising the States of Arkansas, Louisiana, Oklahoma, and Texas is the only geographic division that reported an increased ratio of Negro farmers per 1,000 Negro population, and it was this group of Southwestern States that reported the largest increase of Negro farmers, each State in the group having reported increases over 1920, as is shown in Table 35.

Table 8.-Negro and White Farm Operators-Increase, 1920 to 1930 , and Number of Operators Per 1,000 Popdlation, 1930 and 1920, by Sections and Southern Divisions

[A minus sign (-) denotes decrease]

\begin{tabular}{|c|c|c|c|c|c|c|c|c|}
\hline \multirow{3}{*}{ SECTION AND DIVISION } & \multicolumn{4}{|c|}{ INCREASE, 1920-1930 } & \multicolumn{4}{|c|}{$\begin{array}{l}\text { FARM OPERATORS PER } 1,000 \\
\text { POPULATION }\end{array}$} \\
\hline & \multicolumn{2}{|c|}{ Farm operators } & \multicolumn{2}{|c|}{ Per cent } & \multicolumn{2}{|c|}{ Negro } & \multicolumn{2}{|c|}{ White } \\
\hline & Negro & White & Negro & White & 1930 & 1920 & 1930 & 1920 \\
\hline United States... & $-42,858$ & $-125,878$ & -4.8 & -2.3 & 74 & 88 & 49 & 58 \\
\hline 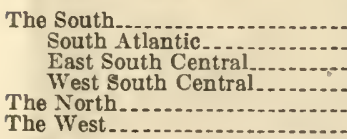 & $\begin{array}{r}-44,659 \\
-86,344 \\
13,594 \\
28,091 \\
1,724 \\
77\end{array}$ & $\begin{array}{r}58,379 \\
-15,055 \\
-3,113 \\
76,547 \\
-204,374 \\
20,110\end{array}$ & $\begin{array}{r}-4.9 \\
-22.6 \\
4.4 \\
12.4 \\
18.4 \\
10.5\end{array}$ & $\begin{array}{r}2.6 \\
-1.9 \\
-0.4 \\
10.0 \\
-7.4 \\
4.3\end{array}$ & $\begin{array}{r}93 \\
67 \\
121 \\
111 \\
5 \\
7\end{array}$ & $\begin{array}{r}103 \\
88 \\
122 \\
110 \\
6 \\
9\end{array}$ & $\begin{array}{r}85 \\
67 \\
103 \\
92 \\
36 \\
45\end{array}$ & $\begin{array}{r}95 \\
80 \\
117 \\
94 \\
44 \\
54\end{array}$ \\
\hline
\end{tabular}


Age of colored operators.- No separate tabulations were made of the two inquiries concerning the age and the term of occupancy of Negro farmers, who with the Indian, Japanese, Chinese, and other nonwhite farmers are included under the general classification "Colored farm operators." But as $\mathbf{9 8 . 8}$ per cent of all colored farmers in the South, and 98.5 per cent of those in the seven selected Northern States here presented are Negroes, and for the additional reason that nearly 85 per cent (84.7) of all Negro farmers in the North and West are located in these seven States, it is believed that the data on age and term of occupancy shown in Tables 9, 10, and 11 may be accepted as indicating definite age and occupancy trends among the Negro farmers of the Nation. The above explanation also applies to other tables ( 32 and 34 ) in which the classification colored instead of Negro is used.

According to age.-As shown in Table 9, nearly 97 per cent of the colored farmers under all tenures in the South and fully 98 per cent of those in the seven Northern States reported their ages. Contrary to the rather widespread belief that the operations on Negro farms are being conducted largely, or to an unusual extent, by so-called old men it appears that 76.9 per cent of these farms in the South and 66.8 per cent of those in the selected Northern States were operated by persons under 55 years of age, and that in the South 53 per cent of these operators as compared with 42 per cent in the North were under 45 years of age. This condition also obtains, but to a smaller degree, among the farm owners reported under this classification as shown in Table 10, in which it appears that 57.1 per cent of the farms occupied by owners in the South and 45.9 per cent of those in the selected Northern States are operated by persons under 55 years of age. 


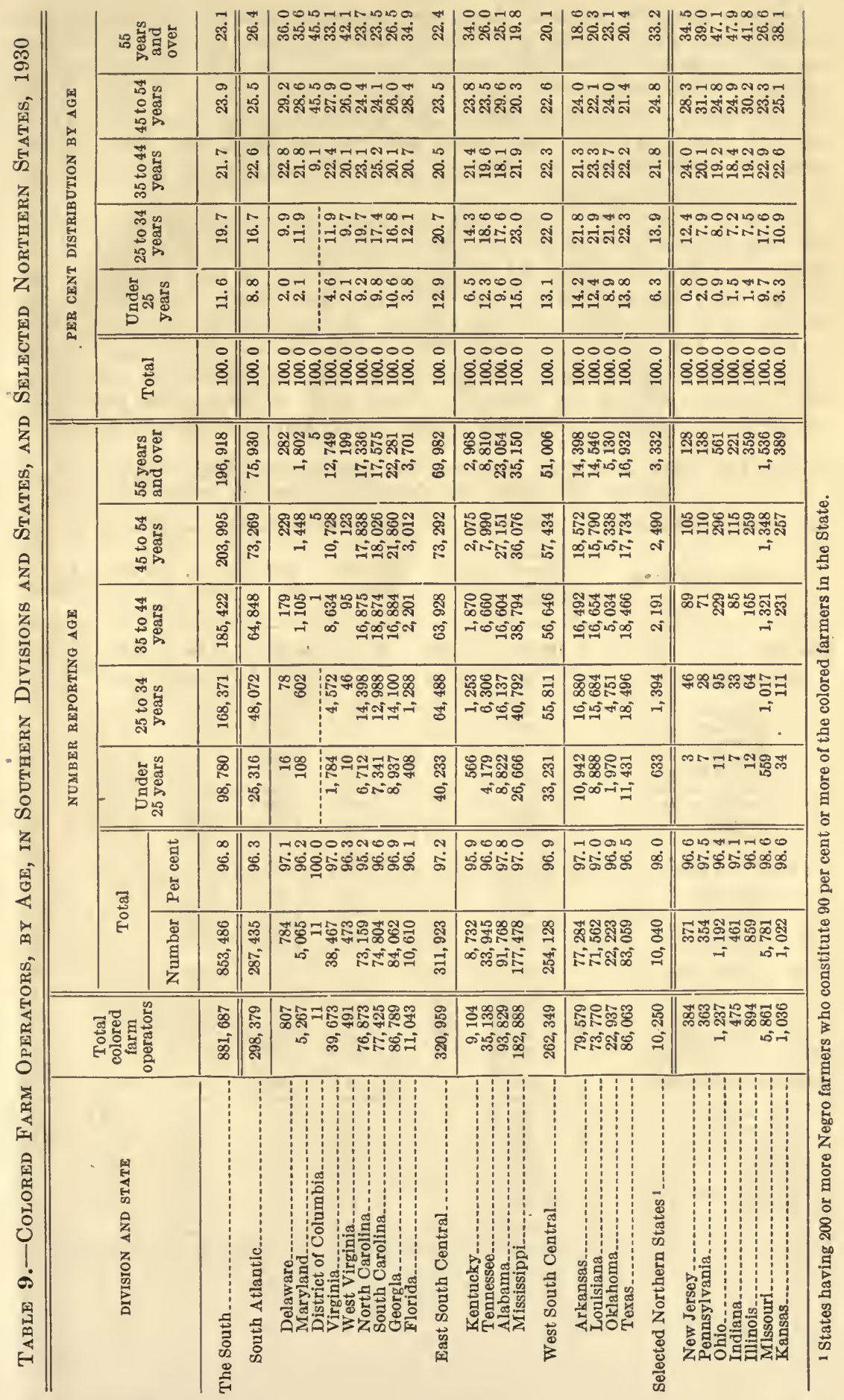


Owners according to age.-Ages were generally reported by colored farm owners, as is shown by Table 10. In both the South and in the selected Northern States 97.6 per cent of the farm owners answered this inquiry. In the South,1.9 per cent of these owners were under 25 years of age; 8.2 per cent between 25 and $34 ; 18.2$ per cent between 35 and $44 ; 28.9$ per cent between 45 and $54 ; 40.5$ per cent, 55 years and over; while 2.4 per cent did not report their ages. In this section, as previously stated, 103,959 , or 57.1 per cent of the colored owners were under 55 years of age.

In the seven Northern States taken as a whole, and where industrial activities are more pronounced than in the South, only one-half of 1 per cent of the owners were under 25 years of age; 5.1 per cent were between 25 and 34 years of age; 15.5 per cent between 35 and 44 years; 24.8 per cent between 45 and $54 ; 51.6$ per cent, 55 years and over, while 2.4 per cent failed to report their ages. Only 45.9 per cent of the owners in these States were under 55 years of age. In this group of States colored owners 55 years of age and over were in the majority in Ohio, Indiana, Illinois, and Missouri. Those under 55 years of age constituted 50 per cent or more of the owners in New Jersey, Pennsylvania, and Kansas.

Table 10.-Colored Farm Owners, by Age, in Southern Divisions and States, and Selected Northern States, 1930

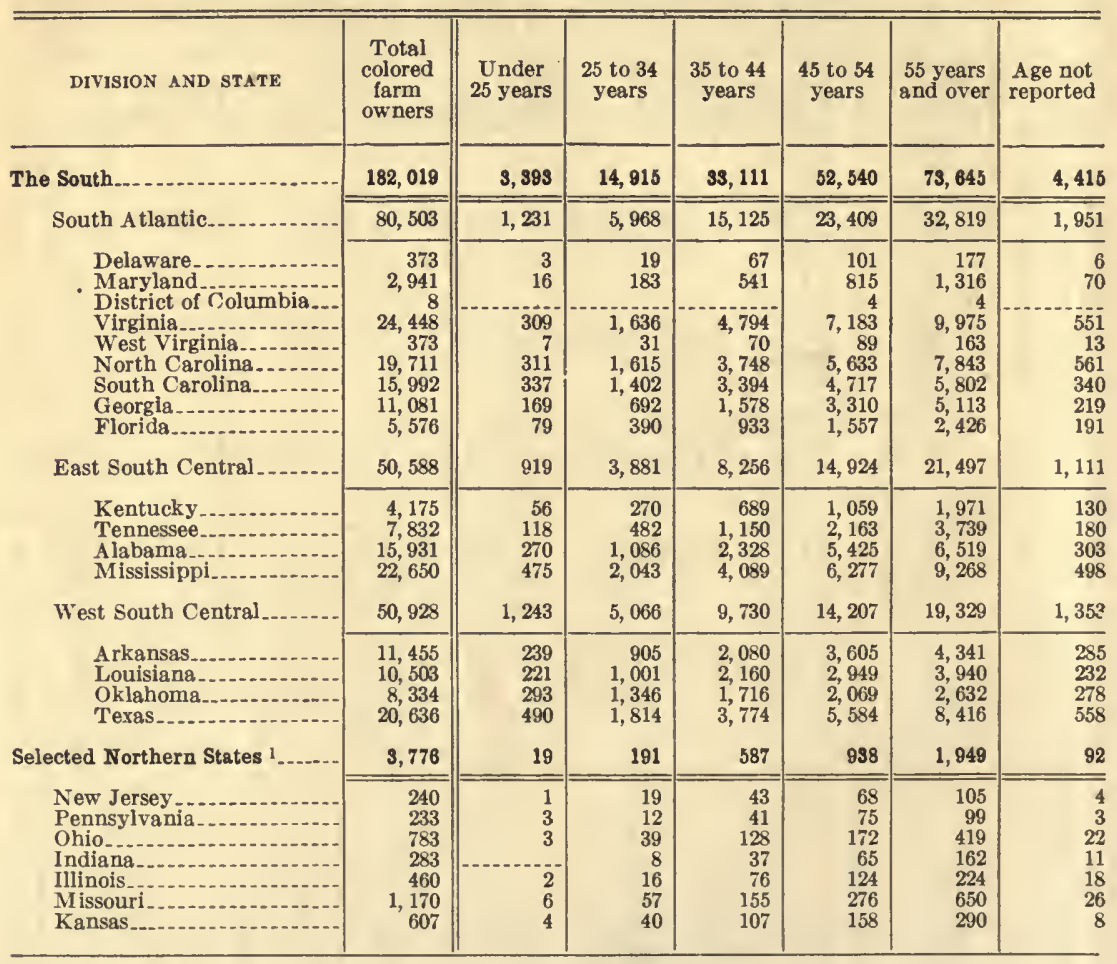

1 States having 200 or more Negro farmers who constitute 90 per cent or more of the colored farmers in the State. 
Term of occupancy.- In the South, 852,232 , or 96.7 per cent, and in the seven selected Northern States 10,033, or 97.9 per cent of the colored farmers, as shown in Table 11, answered the inquiry concerning the number of years they had operated as owners, tenants, or managers of the farms reported by them to the enumerators in April, 1930. For the South as a whole where 79.3 per cent of the colored farmers are tenants, 23.6 per cent of those reporting occupancy had operated that particular farm less than one year, while 40.3 per cent reported an occupancy of less than two years. Arkansas was the only State in the South where 50 per cent or more of the colored farmers reported an occupancy of less than two years. Virginia, West Virginia, and the District of Columbia were the only States in the South or selected northern group in which 50 per cent or more reported an occupancy of 10 years or more. Of the seven Northern States, Missouri, where nearly 80 (79.7) per cent of the colored farm operators are tenants and cotton is extensively grown in the southeastern counties, was the only State that reported an occupancy of less than two years for over 50 per cent of its colored farmers. For the four States, Kansas, Indiana, Ohio, and Illinois an occupancy of 10 years and over was reported respectively for $45.1,44.5,43.8$, and 40.9 per cent of the colored farm operators. Missouri, of course, showed the lowest percentage under the 10-year occupancy, a condition due largely to the high turnover among the tenant class of farmers in the cotton-growing counties of the State. 


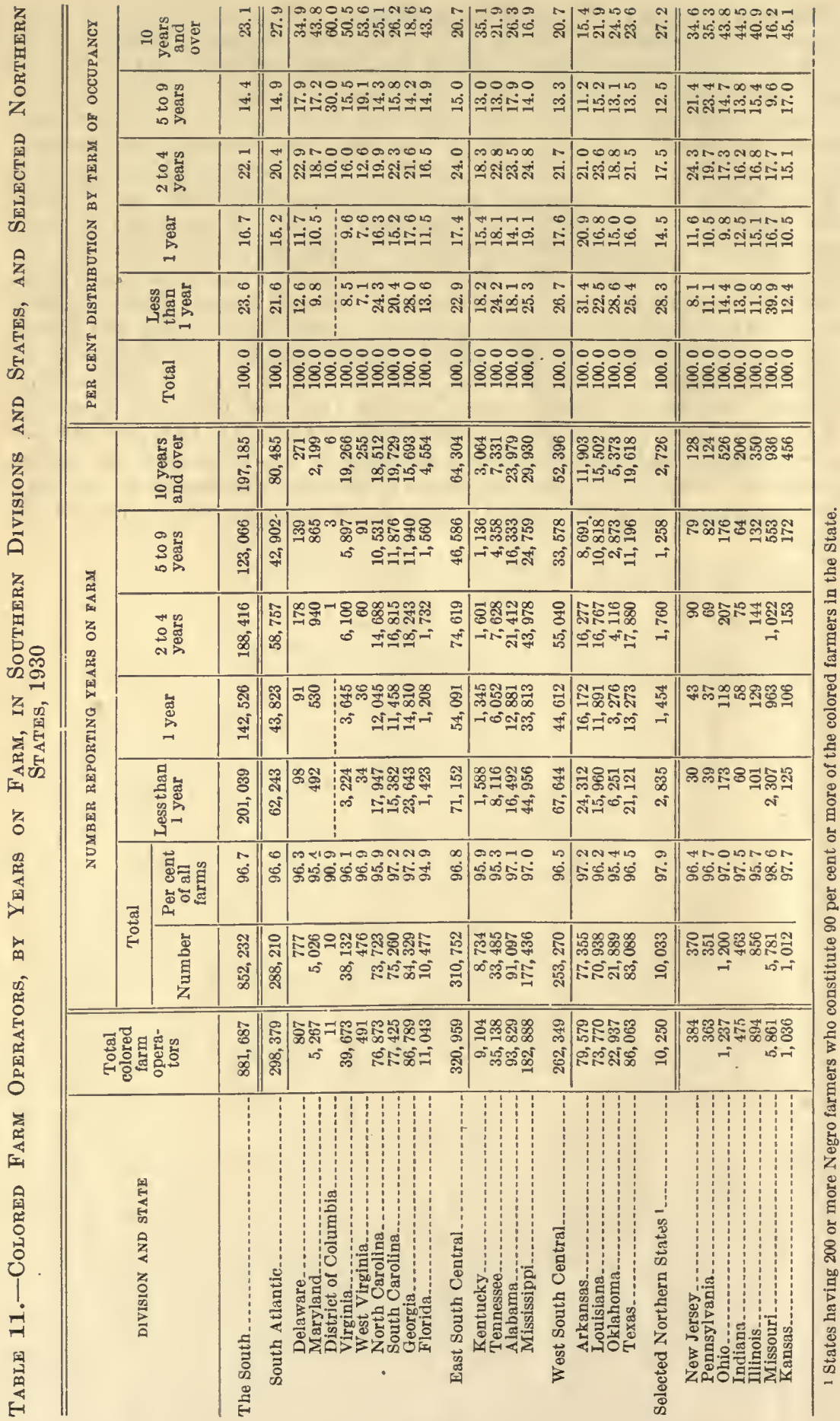




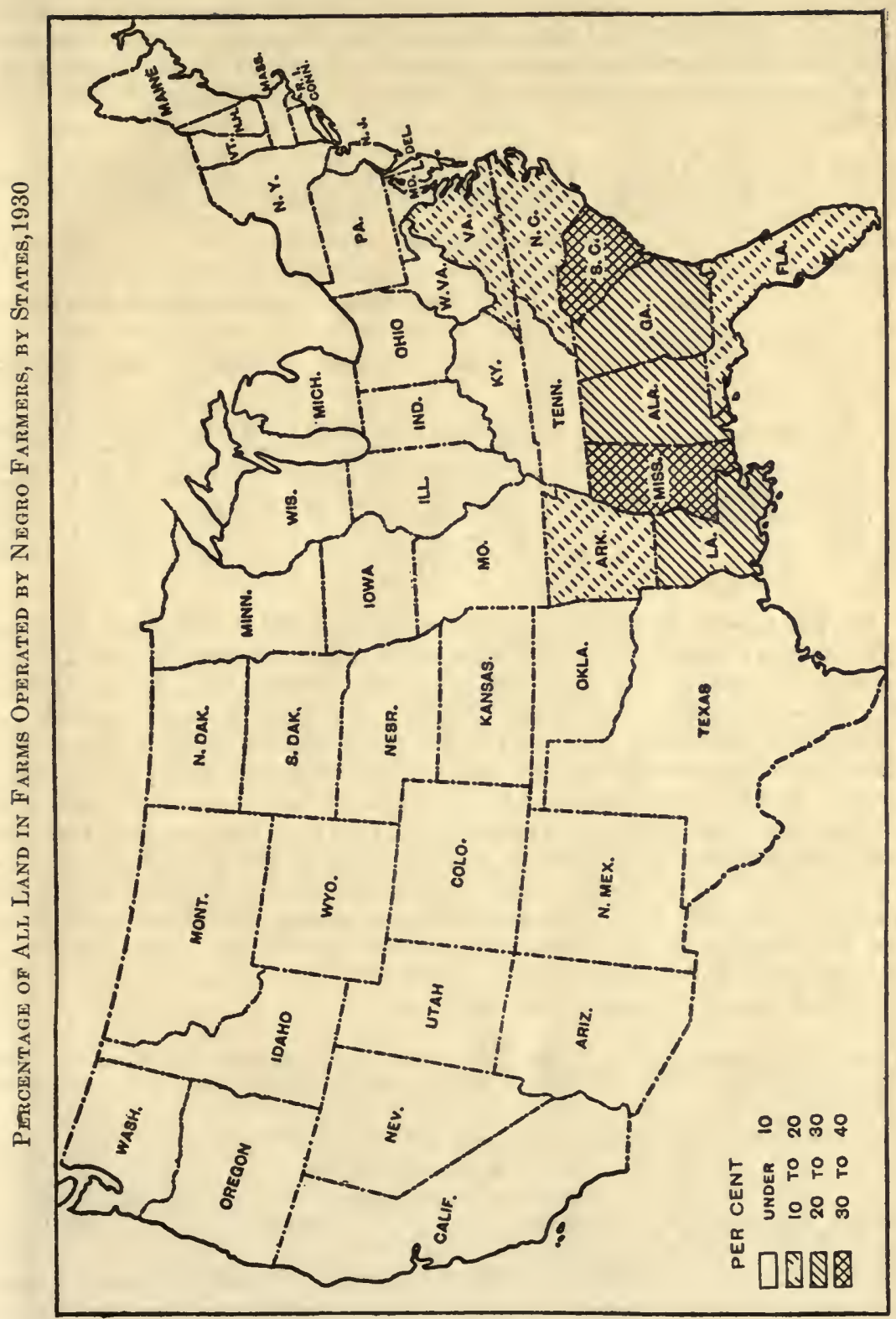


All farm land in the United States.-At the census of 1930, as shown by Table 12 , there were $986,771,016$ acres in farm land as compared with $955,883,715$ in 1920 , or an increase of $30,887,301$ acres during the 10-year period in which as indicated in Table 5, there was a decrease of 159,695 farm operators. Farm acreage in 1930 constituted approximately $1,541,830$ square miles as compared with $1,493,568$ in 1920 , an increase during the decade of 48,262 square miles. This increase was principally in the West, the Mountain and Pacific Coast States.

Table 12.-All Land in Farms (Acres), and Area in Square Miles, by Sections AND Southern Divisions: 1930 AND 1920

[A minus sign (-) denotes decrease]

\begin{tabular}{|c|c|c|c|c|c|}
\hline \multirow[b]{2}{*}{ SECTION AND DIVISION } & \multicolumn{2}{|c|}{ ACRES IN FARMS } & \multicolumn{3}{|c|}{ FARM AREA IN SQUARE MILES } \\
\hline & 1930 & 1920 & 1930 & 1920 & $\begin{array}{l}\text { Increase, } \\
\text { 1920-1930 }\end{array}$ \\
\hline United States.... & $986,771,016$ & $955,883,715$ & $1,541,830$ & $1,493,568$ & 48,262 \\
\hline $\begin{array}{l}\text { The South } \\
\text { South Atlantic. } \\
\text { East South Central } \\
\text { West South Central. } \\
\text { The North } \\
\text { The West. }\end{array}$ & $\begin{array}{r}343,086,418 \\
86,362,715 \\
72,817,357 \\
183,906,346 \\
425,709,428 \\
217,975,170\end{array}$ & $\begin{array}{r}350,121,833 \\
97,775,243 \\
78,897,463 \\
173,449,127 \\
432,271,951 \\
173,489,931\end{array}$ & $\begin{array}{l}536,073 \\
134,942 \\
113,777 \\
287,354 \\
665,171 \\
340,586\end{array}$ & $\begin{array}{l}547,065 \\
152,774 \\
123,277 \\
271,014 \\
675,425 \\
271,078\end{array}$ & $\begin{array}{r}-10,992 \\
-17,832 \\
-9,500 \\
16,340 \\
-10,254 \\
69,508\end{array}$ \\
\hline
\end{tabular}

Acres in farms.-Table 13 shows that Negroes in the United States operated farms having a total of $37,597,132$ acres, or 58,745 square miles in 1930 , an area slightly in excess of the combined land areas of Maryland, Massachusetts, New Jersey, Vermont, and West Virginia. The land in farms operated by them was approximately 2 per cent $(1.97)$ of the total land area in the United States, as compared with 49.7 per cent for white farmers. In the South Negro farmers operated approximately 6.5 per cent of the land area of that section in 1930, and the white farmers 54.3 per cent. In 1920 as in 1930, less than $1,000,000$ acres were operated by Negroes in the North and West. In 36 States, including the District of Columbia, Negro farmers decreased in number between the census periods 1920 and 1930, while the farm acreage diminished in 33 States and the District of Columbia. (See Tables 35 and 36.) The number of white farmers also decreased, but a substantial increase was reported in the number of acres in the farms they operated.

Table 13.-Acreage in Farms Operated by Negroes and Whites, 1930 and 1920; and Area in Square Miles, 1930; by Sections and Southern Divisions

\begin{tabular}{|c|c|c|c|c|c|c|}
\hline \multirow{3}{*}{ SECTION AND DIVISION } & \multicolumn{4}{|c|}{ ACRES IN FARMS OPERATED BY- } & \multirow{2}{*}{\multicolumn{2}{|c|}{$\begin{array}{c}\text { FARM AREA IN } \\
\text { SQUARE MILES, } \\
1930\end{array}$}} \\
\hline & \multicolumn{2}{|c|}{ Negroes } & \multicolumn{2}{|c|}{ Whites } & & \\
\hline & 1930 & 1920 & 1930 & 1920 & Negroes & Whites, \\
\hline Onited States... & $37,597,132$ & $41,432,182$ & $945,683,084$ & $910,939,194$ & 58,745 & $1,477,630$ \\
\hline $\begin{array}{l}\text { The South } \\
\text { South Atlantic } \\
\text { East South Central } \\
\text { West South Central. } \\
\text { The North... } \\
\text { The West... }\end{array}$ & $\begin{array}{r}36,758,484 \\
14,550,451 \\
11,918 ; 057 \\
10,289,976 \\
720,872 \\
117,776\end{array}$ & $\begin{array}{r}40,544,241 \\
18,151,071 \\
12,104,977 \\
10,288,193 \\
767,953 \\
119,988\end{array}$ & $\begin{array}{r}305,280,653 \\
71,704,181 \\
60,886,302 \\
172,690,170 \\
423,963,841 \\
216,438,540\end{array}$ & $\begin{array}{r}308,803,337 \\
79,550,302 \\
66,783,791 \\
162,469,244 \\
430,365,628 \\
171,770,229\end{array}$ & $\begin{array}{r}57,435 \\
22,735 \\
18,622 \\
16,078 \\
1,126 \\
184\end{array}$ & $\begin{array}{r}477,001 \\
112,038 \\
95,135 \\
269,828 \\
662,444 \\
338,185\end{array}$ \\
\hline
\end{tabular}


Land distribution.-In Table 14 the per cent distribution of all land in farms is shown for Negro and white farmers by sections and southern divisions for 1920 and 1930. Although the changes occurring in the South, North, and West, as sections, were inappreciable, in the distribution by geographic divisions composing the South it will be noted that there was a rather marked decrease in the percentage for the South Atlantic division formed by Delaware, Maryland, District of Columbia, Virginia, West Virginia, North Carolina, South Carolina, Georgia, and Florida, in each of which, except West Virginia, the land in farms operated by Negroes decreased during the 10 years. (See Table 36.)

In the State of South Carolina the farm acreage operated by Negroes was less by $1,211,971$ acres in 1930 than it was in 1920 , a decrease of 27.7 per cent. In Georgia there was a decrease of $1,966,491$ acres, or 27.8 per cent. In other words, in these two States the farm acreage operated by Negroes in 1930 was less than three-fourths of what it was in 1920. This decrease in the farm acreage was accompanied by a decrease of 29.1 per cent in the number of Negro farm operators in South Carolina, and of 33.3 per cent in the number of Negro farm operators in Georgia as shown in Table 35. No other States show as marked declines in the amount of acreage and number of farms operated by Negroes, although the percentage of decrease was fairly large in Florida and Kentucky. There was some decrease of acreage in North Carolina in Alabama and in Arkansas, practically no change in Texas, and an increase in Mississippi and Louisiana.

It is interesting to note, in connection with the decrease reported for Negro farm operators in Georgia and South Carolina, that the Negro population in each of these States also decreased; Georgia reporting a loss of 135,240, and South Carolina 71,038. The Negro rural-farm population in each of these States showed even greater losses, a decrease of 199,211 in Georgia and one of 141,516 in South Carolina or a total decrease of 340,727 in the Negro rural-farm population of these two States. The urban Negro population of Georgia increased by only 43,601 as compared with an urban increase of 21,865 in South Carolina.

Table 14.-Per Cent Distribution of Acreage in Farms Operated by Negroes and Whites, by Sections and Southern Divisions: 1930 and 1920

\begin{tabular}{|c|c|c|c|c|}
\hline \multirow{3}{*}{ SECTION AND DIVISION } & \multicolumn{4}{|c|}{ ACRES IN FARMS } \\
\hline & \multicolumn{2}{|c|}{ Negroes } & \multicolumn{2}{|c|}{ Whites } \\
\hline & 1930 & 1920 & 1930 & 1920 \\
\hline United States......... & 100.0 & 100.0 & 100.0 & 100.0 \\
\hline $\begin{array}{l}\text { The South } \\
\text { South Atlantic } \\
\text { East South Central } \\
\text { West South Central Sol } \\
\text { The North } \\
\text { The West.............. }\end{array}$ & $\begin{array}{r}97.8 \\
38.7 \\
31.7 \\
27.4 \\
1.9 \\
0.3\end{array}$ & $\begin{array}{r}97.9 \\
43.8 \\
29.2 \\
24.8 \\
1.9 \\
0.3\end{array}$ & $\begin{array}{r}32.3 \\
7.6 \\
6.4 \\
18.3 \\
44.8 \\
22.9\end{array}$ & $\begin{array}{r}33.9 \\
8.7 \\
7.3 \\
17.8 \\
47.2 \\
18.9\end{array}$ \\
\hline
\end{tabular}

Acreage increases and decreases.-Increases and decreases in the acreage of land in farms operated by Negroes and by whites in the South, North, and West, and by each geographic division in the South are shown in Table 15. The total decrease of $3,835,050$ acres reported for Negro farmers was the result of a reduction of 3,785,757 acres in the South; 47,081 in the North, and 2,212 in the West. Due to increases in Louisiana and Oklahoma the West South Central division 
was able to show a slight increase of 1,783 acres. Of the 17 States forming the South, including the District of Columbia, four, Louisiana, Mississippi, Oklahoma, and West Virginia reported expansions in land operated by Negroes. Although 11 States in the North and West, including Illinois, Wisconsin, Minnesota, Iowa, Missouri, Idaho, Wyoming, New Mexico, Arizona, Nevada, and Washington showed increased acreages for Negro farmers, the remaining 21 States of the North and West reported an aggregate decrease too large to be offset by the increase of 93,938 acres in the 11 States named. (See Table 36.) The decrease between 1920 and 1930 of acres in land farmed by Negroes is equal to 5,992 square miles, or an area slightly larger than Connecticut, Rhode Island, and the District of Columbia combined. For white farmers the acreage decreases in 30 States were more than offset by increases in 19 States producing a net total increase of $34,743,840$ acres, or 54,287 square miles, an area larger than the States of Alabama and Delaware combined.

Table 15.-Increase in Acreage and Square Miles in Farms Operated by Negroes and Whites, 1920 to 1930, by Sections and Southern Divisions

[A minus sign ( $\rightarrow$ ) denotes decrease]

\begin{tabular}{|c|c|c|c|c|c|c|}
\hline \multirow{3}{*}{ SECTION AND DIVISION } & \multicolumn{6}{|c|}{ INCREASE, $1920-1930$} \\
\hline & \multicolumn{2}{|c|}{ Acres in farms } & \multicolumn{2}{|c|}{ Area (square miles) } & \multicolumn{2}{|c|}{ Per cent } \\
\hline & Negroes & Whites & Negroes & Whites & Negroes & Whites \\
\hline Onited States..... & $-3,835,050$ & $34,743,840$ & $-5,892$ & 54,287 & -9.3 & 3.8 \\
\hline 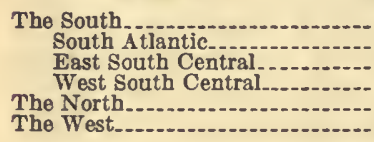 & $\begin{array}{r}-3,785,757 \\
-3,600,620 \\
-186,920 \\
1,783 \\
-47,081 \\
-2,212\end{array}$ & $\begin{array}{r}-3,522,684 \\
-7,846,121 \\
-5,897,489 \\
10,220,926 \\
-6,401,787 \\
44,668,311\end{array}$ & $\begin{array}{r}-5,915 \\
-5,626 \\
-292 \\
3 \\
-74 \\
-3\end{array}$ & $\begin{array}{r}-5,504 \\
-12,259 \\
-9,215 \\
15,970 \\
-10,003 \\
69,794\end{array}$ & $\begin{array}{l}-9.3 \\
-19.8 \\
-1.5 \\
(1) \\
-6.2 \\
-1.6\end{array}$ & $\begin{array}{r}-1.1 \\
-9.9 \\
-8.8 \\
6.3 \\
-1.5 \\
26.0\end{array}$ \\
\hline
\end{tabular}

1 Less than one-tenth of 1 per cent.

Average acreage per farm.-The average number of acres per farm, for Negro and white farms in 1930 and 1920, is shown in Table 16 by sections and for the Southern States, with the decrease in the average size of farms during the decade.

The average acreage per Negro farm in the United States decreased from 44.8 acres in 1920 to 42.6 acres in 1930, the decrease amounting in the average to 2.2 acres. During the 20 years from 1910 to 1930 the average decrease amounted to 4.7 acres. White farms increased in the average acreage from 165.7 in 1920 to 176 in 1930 giving an increase for the decade of 10.3 acres. From 1910 to 1930 , a 20 -year period, the average acreage of white farms increased 23 acres, a gain that is equal to more than one-half ( 54 per cent) of the average acreage in Negro farmers.

Taking the South as a whole the average acreage per farm of Negro farms decreased by 2.1 acres during the decade, but in the South Atlantic division where a decrease of 86,344 Negro farmers and 3,600,620 acres of land was reported, there was an increase of 1.7 acres in the average acreage of Negro farms as compared with a loss of 8.3 acres in the white farms. In the East South Central the average acreage in Negro farms was reduced during the decade by 2.2 acres, and in the West South Central by 5.1 acres. There were seven States in the South, led by Maryland and including Delaware, Georgia, Virginia, Kentucky, West Virginia, and South Carolina, in the order named, that reported increased average acreages for the 10-year period, although each of these States had fewer Negro farmers in 1930 than in 1920 and, with the exception of West Virginia, less acreage. 
In the North the average acreage was reduced by 17 acres, or from 81.9 in 1920 to 64.9 in 1930 , as compared with a 10 -acre average increase for white farmers. Similarly in the West the Negro farm average acreage decreased by 18.3 acres, or from 163.7 in 1920 to 145.4 in 1930 while the average acreage per farm of white farmers increased by 76.8 acres, or from 369.8 acres in 1920 to 446.6 acres in 1930 .

Table 16. - Average Acreage Per Farm of Negro and White Operators, by Sections, and Sodthern Divisions and States: 1930 and 1920

[A minus sign (-) denotes decrease]

\begin{tabular}{|c|c|c|c|c|c|c|}
\hline \multirow{3}{*}{ SECTION, DIVISION, AND STATE } & \multicolumn{6}{|c|}{ AVERAGE ACREAGE PER FARM OPERATED BY- } \\
\hline & \multicolumn{3}{|c|}{ Negroes } & \multicolumn{3}{|c|}{ Whites } \\
\hline & 1930 & 1920 & Increase & 1930 & 1920 & Increase \\
\hline United States........................... & 42.6 & 44.8 & -2.2 & 176.0 & 165.7 & 10.8 \\
\hline The South & 42.2 & 44.3 & -2.1 & 130.3 & 135.2 & -4.9 \\
\hline $\begin{array}{l}\text { South Atlantic. } \\
\text { East South Central } \\
\text { West South Central. } \\
\text { The North } \\
\text { The West. }\end{array}$ & $\begin{array}{r}49.2 \\
37.2 \\
40.4 \\
64.9 \\
145.4\end{array}$ & $\begin{array}{r}47.5 \\
39.4 \\
45.5 \\
81.9 \\
163.7\end{array}$ & $\begin{array}{r}1.7 \\
-2.2 \\
-5.1 \\
-17.0 \\
-18.3 \\
\end{array}$ & $\begin{array}{r}94.3 \\
82.1 \\
205.4 \\
166.5 \\
446.6\end{array}$ & $\begin{array}{r}102.6 \\
89.7 \\
212.6 \\
156.5 \\
369.8\end{array}$ & $\begin{array}{r}-8.3 \\
-7.6 \\
-7.2 \\
10.0 \\
76.8\end{array}$ \\
\hline THE SOUTH & & & & & & \\
\hline $\begin{array}{l}\text { SoUTH A TLANTic: } \\
\text { Delaware } \\
\text { Maryland } \\
\text { District of Columbia. } \\
\text { Virginia } \\
\text { West Virginia } \\
\text { North Carolina } \\
\text { South Carolina } \\
\text { Georgia } \\
\text { Florida } \\
\text { EAst SodTH CENTRAL: }\end{array}$ & $\begin{array}{r}67.9 \\
65.6 \\
8.6 \\
51.5 \\
57.2 \\
44.2 \\
41.0 \\
58.8 \\
46.7\end{array}$ & $\begin{array}{l}62.9 \\
56.6 \\
14.4 \\
47.3 \\
54.7 \\
45.0 \\
40.2 \\
54.3 \\
49.2\end{array}$ & $\begin{array}{r}5.0 \\
9.0 \\
-5.8 \\
4.2 \\
2.5 \\
-0.8 \\
0.8 \\
4.5 \\
-2.5\end{array}$ & $\begin{array}{r}95.1 \\
106.2 \\
32.0 \\
112.1 \\
106.8 \\
72.3 \\
89.7 \\
100.6 \\
94.1\end{array}$ & $\begin{array}{r}96.0 \\
105.7 \\
29.2 \\
117.7 \\
110.0 \\
85.7 \\
96.2 \\
101.7 \\
131.8\end{array}$ & $\begin{array}{r}-0.9 \\
0.5 \\
2.8 \\
-5.6 \\
-3.2 \\
-13.4 \\
-6.5 \\
-1.1 \\
-37.7\end{array}$ \\
\hline $\begin{array}{l}\text { EAST SOUTH CENTRAL: } \\
\text { Kentucky } \\
\text { Tennessee } \\
\text { Alabama } \\
\text { Mississippí. } \\
\text { West SouTH CENTRAL: }\end{array}$ & $\begin{array}{l}37.5 \\
38.6 \\
44.3 \\
33.2\end{array}$ & $\begin{array}{l}33.8 \\
39.9 \\
45.7 \\
36.1\end{array}$ & $\begin{array}{r}3.7 \\
-1.3 \\
-1.4 \\
-2.9\end{array}$ & $\begin{array}{l}82.5 \\
79.1 \\
81.9 \\
86.8\end{array}$ & $\begin{array}{r}82.1 \\
83.8 \\
94.6 \\
111.7\end{array}$ & $\begin{array}{r}0.4 \\
-4.7 \\
-12.7 \\
-24.9\end{array}$ \\
\hline $\begin{array}{l}\text { Arkansas } \\
\text { Louisiana } \\
\text { Oklahoma } \\
\text { Texas }\end{array}$ & $\begin{array}{l}31.2 \\
31.4 \\
70.0 \\
51.5\end{array}$ & $\begin{array}{l}36.3 \\
35.2 \\
78.0 \\
56.5\end{array}$ & $\begin{array}{l}-5.1 \\
-3.8 \\
-8.0 \\
-5.0\end{array}$ & $\begin{array}{r}83.3 \\
80.3 \\
175.9 \\
293.7\end{array}$ & $\begin{array}{r}92.5 \\
106.8 \\
174.5 \\
306.7\end{array}$ & $\begin{array}{r}-9.2 \\
-26.5 \\
1.4 \\
-13.0\end{array}$ \\
\hline
\end{tabular}

Farm property values.-Data relating to the value of land and buildings of farms operated by Negroes for 1920 and 1930, are presented in Table 17. The aggregate value of land and buildings by tenure of operators is shown for 1930 and 1920 by divisions and States in Table 37, and the value of implements aua machinery for 1930 by divisions and States in Table 33.

For several years prior to the World War, and in 1920 during the early postwar period, the value of farm land and buildings was generally inflated throughout the entire country. Between 1920 and 1930 the average value of all land and buildings per farm decreased approximately $\$ 2,670$, or 26 per cent, while the average value of land and buildings per acre fell from $\$ 69.38$ in 1920 , to $\$ 48.52$ in 1930 , a decrease of $\$ 20.86$, or 30.1 per cent per acre. No separate tabulation was made in 1920 of the value of implements and machinery on Negro farms in the United States, but the value of land and buildings for each section and for the United States is reported for both years.

For all farms in the United States the value of land and buildings decreased $\$ 18,436,164,244$, or 27.8 per cent during the decade. The value of land and buildings of Negro-operated farms decreased $\$ 854,699,526$, or 37.9 per cent, and 
the value reported for white operated and all other operated farms decreased by $\$ 17,581,464,718$, or 27.4 per cent. ' Negro farm property (land and buildings) in the South showed a decrease of $\$ 835,823,975$, or 38.1 per cent; in the North $\$ 18,164,242$, or 30.4 per cent, and in the West the value declined $\$ 711,309$, or at rate of 10.4 the per cent during the 10 years. This decrease in the values, in each section, of the farm property operated by each racial group was the result of a reduction in the farm acreage and the shrinkage of land values generally throughout the Nation.

Table 17.-Valde of Land and Buildings of All Farms and of Farms Operated by Negroes, by Sections: 1930 and 1920

[A minus sign (-) denotes decrease]

\begin{tabular}{|c|c|c|c|c|c|c|}
\hline \multirow{3}{*}{ CLASS AND SECTION } & \multicolumn{6}{|c|}{ VALUE OF LAND AND BUILDINGS } \\
\hline & \multirow{2}{*}{1930} & \multirow{2}{*}{1920} & \multicolumn{2}{|c|}{ Increase, $1920-1930$} & \multicolumn{2}{|c|}{$\begin{array}{l}\text { Per cent distri- } \\
\text { bution }\end{array}$} \\
\hline & & & Amount & Per cent & 1930 & 1920 \\
\hline United States.. & $\$ 47,879,838,958$ & $\$ 68,316,002,602$ & $-818,436,164,244$ & -27.8 & 100.0 & 100. 0 \\
\hline $\begin{array}{l}\text { The South-.- } \\
\text { The North.-. } \\
\text { The West.-. }\end{array}$ & $\begin{array}{r}12,343,593,204 \\
28,253,801,121 \\
7,282,444,033 \\
\end{array}$ & $\begin{array}{r}15,156,654,907 \\
43,326,743,178 \\
7,832,604,517 \\
\end{array}$ & $\begin{array}{r}-2,813,061,703 \\
-15,072,942,057 \\
-550,160,484 \\
\end{array}$ & $\begin{array}{l}-18.6 \\
-34.8 \\
-7.0 \\
\end{array}$ & $\begin{array}{l}25,8 \\
59.0 \\
15.2 \\
\end{array}$ & $\begin{array}{l}22.9 \\
65.3 \\
11.8 \\
\end{array}$ \\
\hline Negro_........ & $1,402,945,799$ & $2,257,645,325$ & $-854,699,526$ & -37.9 & 100.0 & 100.0 \\
\hline $\begin{array}{l}\text { The South } \\
\text { The North } \\
\text { The West......... }\end{array}$ & $\begin{array}{r}1,355,181,667 \\
41,668,222 \\
6,095,910\end{array}$ & $\begin{array}{r}2,191,005,642 \\
59,832,464 \\
6,807,219\end{array}$ & $\begin{array}{r}-835,823,975 \\
-18,164,242 \\
-711,309\end{array}$ & $\begin{array}{l}-38.1 \\
-30.4 \\
-10.4\end{array}$ & $\begin{array}{r}96.6 \\
3.0 \\
0.4\end{array}$ & $\begin{array}{r}97.0 \\
2.7 \\
0.3\end{array}$ \\
\hline White $1 . .$. & $46,277,070,671$ & $63,786,058,855$ & $-17,508,988,184$ & -27.4 & 100.0 & 100.0 \\
\hline $\begin{array}{l}\text { The South } \\
\text { The North- } \\
\text { The West. }\end{array}$ & $\begin{array}{r}10,950,488,263 \\
28,194,670,491 \\
7,131,911,917\end{array}$ & $\begin{array}{r}12,928,803,290 \\
43,236,157,733 \\
7,621,097,832\end{array}$ & $\begin{array}{r}-1,978,315,027 \\
-15,041,487,242 \\
-489,185,915\end{array}$ & $\begin{array}{r}-15.3 \\
-34.8 \\
-6.4\end{array}$ & $\begin{array}{l}23.7 \\
60.9 \\
15.4\end{array}$ & $\begin{array}{l}20.3 \\
67.8 \\
11.9\end{array}$ \\
\hline All other nonwhite.-. & $199,821,888$ & $272,298,422$ & $-72,476,534$ & -26.6 & 100.0 & 100.0 \\
\hline $\begin{array}{l}\text { The South } \\
\text { The North } \\
\text { The West }\end{array}$ & $\begin{array}{r}37,923,274 \\
17,462,408 \\
144,436,206\end{array}$ & $\begin{array}{r}36,845,975 \\
30,752,981 \\
204,699,466\end{array}$ & $\begin{array}{r}1,077,299 \\
-13,290,573 \\
-60,263,260\end{array}$ & $\begin{array}{r}2.9 \\
-43.2 \\
-29.4\end{array}$ & $\begin{array}{r}19.0 \\
8.7 \\
72.3\end{array}$ & $\begin{array}{l}13.5 \\
11.3 \\
75.2\end{array}$ \\
\hline
\end{tabular}

I Includes Mexicans and Hindus.

Rank of Southern States.-In Table 18 the number of farms and the value of land and buildings operated by Negroes in Southern States are given for 1930 and for 1920 , with the increase for the decade and rank of the States at each census. In number of farms Mississippi ranked first among the States at each census. Alabama ranked second in 1930, having displaced Georgia which occupied second place, and passed South Carolina which stood in third rank in 1920 . Texas advanced from fifth to fourth place in 1930; Arkansas from seventh to fifth; while South Carolina dropped from third rank to sixth; and North Carolina from sixth rank in 1920 to seventh in 1930 . No changes occurred in the ranks of the remaining 9 States and the District of Columbia.

Ranked according to value of land and buildings, Mississippi continues in first place as in 1920,1910, and 1900. Texas advanced from fourth rank in 1920 to second in 1930. North Carolina occupied third place, having displaced South Carolina. Arkansas advanced from sixth to fourth, Louisiana from eighth to sixth, and Maryland from thirteenth to twelfth rank. Georgia fell from second to fifth rank during the decade; South Carolina from third to seventh; Alabama from seventh to eighth and Kentucky from twelfth to thirteenth place. Each of the other States and the District of Columbia occupied the same rank as in 1920. With the single exception of Louisiana, each State showed a decrease in 
the value of land and buildings operated by Negro farmers. Exclusive of the District of Columbia where the value of land and buildings is very small, the greatest decreases in amount, if not in percentage, were reported for Georgia, South Carolina, Mississippi, North Carolina, and Arkansas, in the order named.

Table 18. - Number of Farms and Value of Land and Buildings of Negro Operators in the Southern States with Rank of the States: 1930 AND 1920

[A minus sign (-) denotes decrease]

\begin{tabular}{|c|c|c|c|c|c|c|}
\hline \multirow{3}{*}{ STATE } & \multicolumn{6}{|c|}{ FARMS IN THE SOUTH OPERATED BY NEGROES } \\
\hline & \multirow{2}{*}{1930} & \multirow{2}{*}{1920} & \multicolumn{2}{|c|}{ Increase, $1920-1930$} & \multicolumn{2}{|c|}{ Rank of States } \\
\hline & & & Number & Per cent & 1930 & 1920 \\
\hline & \multicolumn{6}{|c|}{ NUMBER OF FARMS } \\
\hline The South..... & 870,936 & 915,595 & $-44,659$ & -4.9 & & \\
\hline $\begin{array}{l}\text { Mississippi } \\
\text { Alabama } \\
\text { Georgia } \\
\text { Texas: } \\
\text { Arkansas } \\
\text { South Carolina } \\
\text { North Carolina } \\
\text { Louisiara } \\
\text { Virginia } \\
\text { Tennessee } \\
\text { Oklahoma } \\
\text { Florida } \\
\text { Kentucky } \\
\text { Maryland. } \\
\text { Delaware } \\
\text { West Virginia } \\
\text { Distrlct of Columbia }\end{array}$ & $\begin{array}{r}182,578 \\
93,795 \\
86,787 \\
85,940 \\
79,556 \\
77,331 \\
74,636 \\
73,734 \\
39,598 \\
35,123 \\
15,172 \\
11,010 \\
9,104 \\
5,264 \\
807 \\
490 \\
11\end{array}$ & $\begin{array}{r}161,001 \\
95,200 \\
130,176 \\
78,597 \\
72,275 \\
109,005 \\
74,849 \\
62,036 \\
47,690 \\
38,181 \\
13,403 \\
12,954 \\
12,624 \\
6,208 \\
872 \\
504 \\
20\end{array}$ & $\begin{array}{r}21,577 \\
-1,405 \\
-43,389 \\
7,343 \\
7,281 \\
-31,674 \\
-213 \\
11,698 \\
-8,092 \\
-3,058 \\
1,769 \\
-1,944 \\
-3,520 \\
-944 \\
-65 \\
-14 \\
-9\end{array}$ & $\begin{array}{r}13.4 \\
-1.5 \\
-33.3 \\
9.3 \\
10.1 \\
-29.1 \\
-0.3 \\
18.9 \\
-17.0 \\
-8.0 \\
13.2 \\
-15.0 \\
-27.9 \\
-15.2 \\
-7.5 \\
-2.8 \\
-45.0\end{array}$ & \begin{tabular}{r|}
1 \\
2 \\
3 \\
4 \\
5 \\
6 \\
7 \\
8 \\
9 \\
10 \\
11 \\
12 \\
13 \\
14 \\
15 \\
16 \\
17
\end{tabular} & $\begin{array}{r}1 \\
4 \\
2 \\
5 \\
7 \\
3 \\
6 \\
8 \\
9 \\
10 \\
11 \\
12 \\
13 \\
14 \\
15 \\
16 \\
17\end{array}$ \\
\hline \multirow{2}{*}{$\begin{array}{l}\text { West Virginia } \\
\text { Distrlct of Columbia... }\end{array}$} & \multicolumn{6}{|c|}{ VALUE OF LAND AND BUILDINGS } \\
\hline & $\$ 1,355,181,667$ & $\$ 2,191,005,642$ & $-\$ 835,823,975$ & -38.1 & & \\
\hline $\begin{array}{l}\text { Mississippi } \\
\text { Texas } \\
\text { North Carolina. } \\
\text { Arkansas } \\
\text { Georgia } \\
\text { Louisiana } \\
\text { South Carolina } \\
\text { Alabama } \\
\text { Virginia } \\
\text { Tennessee } \\
\text { Oklahoma } \\
\text { Maryland } \\
\text { Kentucky } \\
\text { Florida } \\
\text { Delaware } \\
\text { West Virginia } \\
\text { District of Columbia }\end{array}$ & $\begin{array}{r}249,305,432 \\
179,391,988 \\
153,882,635 \\
118,180,961 \\
114,688,230 \\
108,668,818 \\
105,693,220 \\
104,726,209 \\
71,722,401 \\
56,339,610 \\
37,967,113 \\
18,896,282 \\
16,157,593 \\
15,369,957 \\
2,628,590 \\
1,480,628 \\
82,000\end{array}$ & $\begin{array}{r}402,438,836 \\
224,864,322 \\
223,666,166 \\
182,378,759 \\
322,706,709 \\
107,615,718 \\
290,406,115 \\
116,894,012 \\
100,839,641 \\
90,427,645 \\
48,640,707 \\
21,651,121 \\
36,067,878 \\
17,561,378 \\
2,885,445 \\
1,727,890 \\
233,300\end{array}$ & $\begin{array}{r}-153,133,404 \\
-45,472,334 \\
-69,783,531 \\
-64,197,798 \\
-208,018,479 \\
1,053,100 \\
-184,712,895 \\
-12,167,803 \\
-29,117,240 \\
-34,088,035 \\
-10,677,594 \\
-2,754,839 \\
-19,910,285 \\
-2,191,421 \\
-256,855 \\
-247,262 \\
-151,300\end{array}$ & $\begin{array}{r}-38.1 \\
-20.2 \\
-31.2 \\
-35.2 \\
-64.5 \\
1.0 \\
-63.6 \\
-10.4 \\
-28.9 \\
-37.7 \\
-21.9 \\
-12.7 \\
-55.2 \\
-12.5 \\
-8.9 \\
-14.3 \\
-64.9\end{array}$ & $\begin{array}{r}1 \\
2 \\
3 \\
4 \\
5 \\
6 \\
7 \\
8 \\
9 \\
10 \\
11 \\
12 \\
13 \\
14 \\
15 \\
16 \\
17 \\
\end{array}$ & $\begin{array}{r}1 \\
4 \\
5 \\
6 \\
2 \\
8 \\
3 \\
7 \\
9 \\
10 \\
11 \\
13 \\
12 \\
14 \\
15 \\
16 \\
17\end{array}$ \\
\hline
\end{tabular}

Rank of Northern and Western States.-Table 19 distributes the number of farms and the value of land and buildings operated by Negroes in the Northern and Western States for 1920 and 1930 with the increase for the decade, and also shows the rank of the States at each census.

Chiefly, if not entirely, ascribable to the interstate migratory movement during the decade an aggregate increase of 1,801 Negro farmers was reported at the census of 1930,8 of the 32 States constituting this territory including, in the order named, 
Missouri, California, Arizona, New Mexico, Iowa, Wisconsin, Maine, and Illinois having contributed to the increase. Only two of these States had 1,000 or more Negro farmers, as compared with three States in 1920, and as in 1920 Missouri ranked in first place, followed by Ohio, Kansas, and Illinois. In actual numbers, Missouri, California, Arizona, and New Mexico had the largest gains. Ranked according to the value of land and buildings, Missouri, Kansas, Ohio, and Illinois occupied first, second, third, and fourth places each year.

Table 19. - Number of Farms and Valde of Land and Buildings of Negro Operators in the Northern and Western States, With Rank of the STATES: 1930 AND 1920

[A minus sign (-) denotes decrease]

\begin{tabular}{|c|c|c|c|c|c|c|}
\hline \multirow{3}{*}{ STATE } & FARMS & THE NORTH & W WEST OPER & ATED BY NE & GROES & \\
\hline & \multirow{2}{*}{1930} & \multirow{2}{*}{1920} & \multicolumn{2}{|c|}{ Increase, $1920-1930$} & \multicolumn{2}{|c|}{ Rank of States } \\
\hline & & & Number & Per cent 1 & 1930 & 1920 \\
\hline \multirow{2}{*}{ The North and West....... } & \multicolumn{6}{|c|}{ NUMBER OF FARMS } \\
\hline & 11,914 & 10,113 & 1,801 & 17.8 & 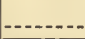 & \\
\hline 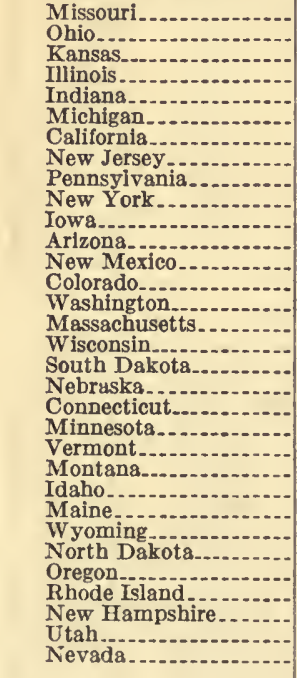 & $\begin{array}{r}5,844 \\
1,229 \\
941 \\
893 \\
461 \\
427 \\
424 \\
372 \\
353 \\
148 \\
118 \\
87 \\
82 \\
78 \\
73 \\
63 \\
55 \\
40 \\
38 \\
33 \\
27 \\
22 \\
21 \\
16 \\
15 \\
12 \\
10 \\
9 \\
9 \\
6 \\
5 \\
3\end{array}$ & $\begin{array}{r}2,824 \\
1,616 \\
1,135 \\
892 \\
570 \\
549 \\
290 \\
531 \\
451 \\
245 \\
109 \\
32 \\
32 \\
148 \\
79 \\
103 \\
47 \\
47 \\
63 \\
65 \\
33 \\
28 \\
31 \\
23 \\
13 \\
17 \\
26 \\
15 \\
19 \\
14 \\
61 \\
5\end{array}$ & $\begin{array}{r}3,020 \\
-387 \\
-194 \\
1 \\
-109 \\
-122 \\
134 \\
-159 \\
-98 \\
-97 \\
9 \\
55 \\
50 \\
-70 \\
-6 \\
-40 \\
8 \\
-7 \\
-25 \\
-32 \\
-6 \\
-6 \\
-10 \\
-7 \\
2 \\
-5 \\
-16 \\
-6 \\
-10 \\
-8 \\
-56 \\
-2\end{array}$ & $\begin{array}{r}106.9 \\
-23.9 \\
-17.1 \\
0.1 \\
-19.1 \\
-22.2 \\
46.2 \\
-29.9 \\
-21.7 \\
-39.6 \\
8.3 \\
-47.3 \\
-38.8 \\
\end{array}$ & $\begin{array}{r}1 \\
2 \\
3 \\
4 \\
5 \\
6 \\
7 \\
8 \\
9 \\
10 \\
11 \\
12 \\
13 \\
14 \\
15 \\
16 \\
17 \\
18 \\
19 \\
20 \\
21 \\
22 \\
23 \\
24 \\
25 \\
26 \\
27 \\
29 \\
28 \\
29 \\
30 \\
31\end{array}$ & $\begin{array}{r}1 \\
2 \\
3 \\
4 \\
5 \\
6 \\
9 \\
7 \\
8 \\
10 \\
12 \\
20 \\
20 \\
11 \\
14 \\
13 \\
18 \\
18 \\
16 \\
15 \\
19 \\
22 \\
21 \\
24 \\
29 \\
26 \\
23 \\
27 \\
25 \\
28 \\
17 \\
30\end{array}$ \\
\hline Nevada.................. & \multicolumn{6}{|c|}{ VALUE OF LAND AND BUILDINGS } \\
\hline The North and West_...-... & $\$ 47,764,132$ & $\$ 66,639,683$ & $-\$ 18,875,551$ & -28.3 & & \\
\hline $\begin{array}{l}\text { Missouri } \\
\text { Kansas. } \\
\text { Ohio } \\
\text { Illinois } \\
\text { California. } \\
\text { Pennsylvania. } \\
\text { New Jersey } \\
\text { Indiana. } \\
\text { Michigan } \\
\text { Iowa } \\
\text { New York. } \\
\text { Arizona } \\
\text { Colorado }\end{array}$ & $\begin{array}{r}14,498,297 \\
6,093,760 \\
5,434,735 \\
3,704,618 \\
3,669,275 \\
2,194,280 \\
2,070,400 \\
1,947,915 \\
1,874,378 \\
878,234 \\
875,575 \\
761,510 \\
445,540\end{array}$ & $\begin{array}{r}16,524,007 \\
9,515,735 \\
9,126,482 \\
6,082,675 \\
3,625,525 \\
3,261,060 \\
2,117,590 \\
4,254,030 \\
2,566,855 \\
1,330,600 \\
1,558,950 \\
277,700 \\
944,405\end{array}$ & $\begin{array}{r}-2,025,710 \\
-3,421,975 \\
-3,691,747 \\
-2,378,057 \\
43,750 \\
-1,066,780 \\
-47,190 \\
-2,306,115 \\
-692,477 \\
-452,366 \\
-683,375 \\
483,810 \\
-498,865\end{array}$ & $\begin{array}{r}-12.3 \\
-36.0 \\
-40.5 \\
-39.1 \\
1.2 \\
-32.7 \\
-2.2 \\
-54.2 \\
-27.0 \\
-34.0 \\
-43.8 \\
174.2 \\
-52.8\end{array}$ & $\begin{array}{r}1 \\
2 \\
3 \\
4 \\
5 \\
6 \\
7 \\
8 \\
9 \\
10 \\
11 \\
12 \\
13\end{array}$ & $\begin{array}{r}1 \\
2 \\
3 \\
4 \\
6 \\
7 \\
9 \\
5 \\
8 \\
11 \\
10 \\
21 \\
13\end{array}$ \\
\hline
\end{tabular}

1 Per cent not shown where base is less than 100 . 
Table 19. -Number of Farms and Value of Land and Buildings of Negro Operators in the Northern and Western States, With Rank of the STATES: 1930 AND 1920-Continued

\begin{tabular}{|c|c|c|c|c|c|c|}
\hline \multirow{3}{*}{ STATE } & \multicolumn{6}{|c|}{ FARMS IN THE NORTH AND WEST OPERATED BY NEGROES } \\
\hline & \multirow{2}{*}{1930} & \multirow{2}{*}{1920} & \multicolumn{2}{|c|}{ Increase, $1920-1930$} & \multicolumn{2}{|c|}{ Rank of States } \\
\hline & & & Number & Per cent & 1930 & 1920 \\
\hline & \multicolumn{6}{|c|}{ VALUE OF LAND AND BUILDINGS-continued } \\
\hline 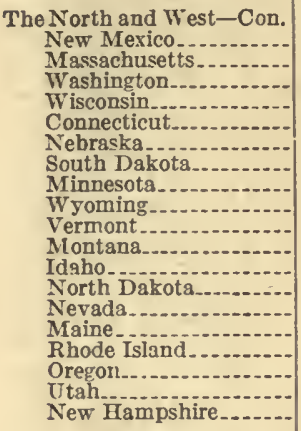 & $\begin{array}{r}\$ 400,956 \\
376,595 \\
356,705 \\
343,105 \\
314,700 \\
308,080 \\
285,425 \\
187,325 \\
139,020 \\
118,700 \\
115,084 \\
107,200 \\
62,700 \\
44,000 \\
41,400 \\
40,000 \\
32,420 \\
24,200 \\
18,000\end{array}$ & $\begin{array}{r}\$ 124,894 \\
345,800 \\
538,480 \\
278,700 \\
498,990 \\
1,095,040 \\
623,515 \\
134,670 \\
131,410 \\
116,725 \\
240,310 \\
134,900 \\
285,740 \\
19,150 \\
54,400 \\
31,500 \\
119,400 \\
651,045 \\
29,400\end{array}$ & $\begin{array}{r}\$ 276,062 \\
30,795 \\
-181,775 \\
64,405 \\
-184,290 \\
-785,960 \\
-338,090 \\
52,655 \\
7,610 \\
1,975 \\
-125,226 \\
-27,700 \\
-223,040 \\
24,850 \\
-13,000 \\
8,500 \\
-88,980 \\
-626,815 \\
-11,400\end{array}$ & $\begin{array}{r}221.0 \\
8.9 \\
-33.8 \\
23.1 \\
-36.9 \\
-71.9 \\
-54.2 \\
39.1 \\
5.8 \\
1.7 \\
-52.1 \\
-20.5 \\
-78.1 \\
129.8 \\
-23.9 \\
27.0 \\
-72.8 \\
-96.3 \\
-38.8\end{array}$ & $\begin{array}{l}14 \\
15 \\
16 \\
17 \\
18 \\
19 \\
20 \\
21 \\
22 \\
23 \\
24 \\
25 \\
26 \\
27 \\
28 \\
29 \\
30 \\
31 \\
32\end{array}$ & $\begin{array}{l}26 \\
18 \\
16 \\
20 \\
17 \\
12 \\
15 \\
24 \\
25 \\
28 \\
22 \\
23 \\
19 \\
32 \\
29 \\
30 \\
27 \\
14 \\
31\end{array}$ \\
\hline
\end{tabular}

Rural Migrants Absorbed by Industry.-That the migration, during the 20 years 1910 to 1930, of a large number of Negroes from the rural districts of the South, and the increase of the rural Negro population in the States comprising the North and West as indicated in Table 3 has not contributed to an increase of Negro farmers in the 21 States forming the North, and only to a very small extent in the 11 States composing the West is shown in Table 20.

From 1910 to 1930 there was a decrease of 10,520 Negro farmers in the United States, as compared with a decrease of 68,041 white farmers. Dividing the country into sections, the North lost 948 and the South 9,900 Negro farmers while the West gained 328. Every important agricultural State in the North except Wisconsin and Missouri, and all in the South except North Carolina, Mississippi, Arkansas, Louisiana, Oklahoma, and Texas reported decreases. In the West slight increases were reported for California, Arizona, New Mexico, and Idaho.

The peak of the number of Negro farmers in the United States, and in the South was reached in 1920. The North had more in 1910 than in 1920 or 1930. Out in the West small increases were reported at each census, particularly in California, New Mexico, and Idaho. The South registered a decrease of 9,900 for the 20 years from 1910 to 1930 , also a loss of 44,659 in 1930 as compared with 1920 . Although considerable increases during the 20 years were reported for North Carolina and Mississippi, the greater trend was toward the States of Louisiana, Arkansas, Oklahoma, and Texas whose combined increase of 52,980 Negro farmers was somewhat less, however, than the loss $(55,208)$ sustained by the two States of Georgia and South Carolina.

That the requirement of industry for labor was the magnet that lured so many Negro farmers and rural-farm inhabitants to the urban centers is indicated by the occupational statistics which show that in the manufacturing and mechanical industries alone, there was an approximate increase of 368,750 , or 56.2 per cent in the number of Negro workers during the 20 years from 1910 to 1930. 
Table 20.-Number of Negro Farm Operators, 1930 and 1910, With Increase During the 20-Year Period, 1910 to 1930, by Sections, Divisions, ANd States

[A minus sign ( $($ ) denotes decrease]

\begin{tabular}{|c|c|c|c|c|c|c|c|}
\hline \multirow[b]{2}{*}{$\begin{array}{l}\text { SECTION, DIVISION, AND } \\
\text { STATE }\end{array}$} & \multicolumn{3}{|c|}{$\begin{array}{c}\text { NEGRO FARM OPERA- } \\
\text { TORS }\end{array}$} & \multirow[b]{2}{*}{$\begin{array}{l}\text { SECTION, DIVISION, AND } \\
\text { STATE }\end{array}$} & \multicolumn{3}{|c|}{$\begin{array}{c}\text { NEGRO FARM OPERA } \\
\text { TORS }\end{array}$} \\
\hline & 1930 & 1910 & $\begin{array}{l}\text { In- } \\
\text { crease, } \\
1910- \\
1930, \\
\text { (num- } \\
\text { ber) }\end{array}$ & & 1930 & 1910 & $\begin{array}{c}\text { In- } \\
\text { crease, } \\
1910- \\
1930, \\
\text { (num- } \\
\text { ber) }\end{array}$ \\
\hline United States & 882,850 & 893,370 & $-10,520$ & South Atlantic & 295,934 & 354,530 & $-58,596$ \\
\hline $\begin{array}{l}\text { The North- } \\
\text { The South. } \\
\text { The West. }\end{array}$ & $\begin{array}{r}11,104 \\
870,936 \\
810 \\
\end{array}$ & $\begin{array}{r}12,052 \\
880,836 \\
482 \\
\end{array}$ & $\begin{array}{r}-948 \\
-8,900 \\
328 \\
\end{array}$ & $\begin{array}{l}\text { Delaware } \\
\text { Maryland } \\
\text { District of Colun } \\
\text { Virginia }\end{array}$ & $\begin{array}{r}807 \\
5,264 \\
11 \\
39,598\end{array}$ & \begin{tabular}{|r|}
922 \\
6,370 \\
12 \\
48,039
\end{tabular} & $\begin{array}{r}-115 \\
-1,100 \\
-8,4 \\
-8,441\end{array}$ \\
\hline New England. & 148 & 310 & -162 & $\begin{array}{l}\text { West Virginia-- } \\
\text { North Carolina. }\end{array}$ & $\begin{array}{r}490 \\
74,636\end{array}$ & $\begin{array}{r}707 \\
64,456\end{array}$ & $\begin{array}{r}-217 \\
10,180\end{array}$ \\
\hline $\begin{array}{l}\text { Maine } \\
\text { New Hampshir } \\
\text { Vermont }\end{array}$ & $\begin{array}{r}15 \\
6 \\
22\end{array}$ & $\begin{array}{l}28 \\
14 \\
20\end{array}$ & $\begin{array}{r}-13 \\
-8 \\
2\end{array}$ & $\begin{array}{l}\text { South Carolina } \\
\text { Georgia } \\
\text { Florlda }\end{array}$ & $\begin{array}{l}77,331 \\
86,787 \\
11,010\end{array}$ & $\begin{array}{r}96,772 \\
122,554 \\
14,698\end{array}$ & $\begin{array}{r}-19,441 \\
-35,767 \\
-3,688\end{array}$ \\
\hline Massachusetts. & 63 & 103 & -40 & East South Central. & 320,600 & 324,884 & $-4,284$ \\
\hline $\begin{array}{l}\text { Rhode Island...... } \\
\text { Connecticut....... }\end{array}$ & $\begin{array}{r}9 \\
33 .\end{array}$ & $\begin{array}{r}40 \\
105\end{array}$ & $\begin{array}{l}-31 \\
-72\end{array}$ & $\begin{array}{l}\text { Kentucky } \\
\text { Tennessee....... }\end{array}$ & $\begin{array}{r}9,104 \\
35,123\end{array}$ & $\begin{array}{l}11,709 \\
38,300\end{array}$ & $\begin{array}{l}-2,605 \\
-3,177\end{array}$ \\
\hline Middle Atlantic.. & 873 & 1,310 & -437 & Mississippl & $\begin{array}{r}93,795 \\
182,578\end{array}$ & $\begin{array}{l}110,387 \\
164,488\end{array}$ & $\begin{array}{r}-16,592 \\
18,090\end{array}$ \\
\hline New York...... & 148 & 295 & -147 & West South Central & 254,402 & 201,422 & 52,980 \\
\hline $\begin{array}{l}\text { New Jersey } \\
\text { Pennsylvania... }\end{array}$ & $\begin{array}{l}372 \\
353\end{array}$ & $\begin{array}{l}472 \\
543\end{array}$ & $\begin{array}{l}-100 \\
-190\end{array}$ & $\begin{array}{l}\text { Arkansas. } \\
\text { Louisiana }\end{array}$ & \begin{tabular}{|l|}
79,556 \\
73,734
\end{tabular} & $\begin{array}{l}63,578 \\
54,819\end{array}$ & $\begin{array}{l}15,978 \\
18,915\end{array}$ \\
\hline East North Central_. & 3,065 & 4,843 & $-1,778$ & $\begin{array}{l}\text { Oklahoma } \\
\text { Texas. }\end{array}$ & $\begin{array}{l}15,172 \\
85,940\end{array}$ & $\begin{array}{l}13,209 \\
69,816\end{array}$ & $\begin{array}{r}1,963 \\
16,124\end{array}$ \\
\hline Ohio... & 1,229 & 1,948 & -719 & Mountain & 304 & 219 & 85 \\
\hline $\begin{array}{l}\text { Indian } \\
\text { Illinois }\end{array}$ & $\begin{array}{l}461 \\
893\end{array}$ & $\begin{array}{r}785 \\
1,422\end{array}$ & $\begin{array}{l}-324 \\
-529\end{array}$ & Montana & 21 & 29 & -8 \\
\hline & $\begin{array}{l}893 \\
427\end{array}$ & $\begin{array}{r}1,422 \\
640\end{array}$ & $\begin{array}{l}-029 \\
-213\end{array}$ & Idaho_-_._- & 16 & 13 & 3 \\
\hline Wisconsin & 55 & 48 & & $\begin{array}{l}\text { W yoming } . . . . . \\
\text { Colorado......... }\end{array}$ & $\begin{array}{l}12 \\
78\end{array}$ & $\begin{array}{l}19 \\
81\end{array}$ & $\begin{array}{l}-7 \\
-3\end{array}$ \\
\hline West North Central. & 7,018 & 5,589 & 1,429 & $\begin{array}{l}\text { New Mexico } \\
\text { Arizona }\end{array}$ & $\begin{array}{l}82 \\
87\end{array}$ & $\begin{array}{l}48 \\
12\end{array}$ & $\begin{array}{l}34 \\
75\end{array}$ \\
\hline Minnesota.. & $\begin{array}{r}27 \\
118\end{array}$ & $\begin{array}{r}29 \\
187\end{array}$ & $\begin{array}{l}-2 \\
-69\end{array}$ & $\begin{array}{l}\text { Utah } \\
\text { Nevada............ }\end{array}$ & $\begin{array}{l}5 \\
3\end{array}$ & $\begin{array}{r}11 \\
6\end{array}$ & $\begin{array}{l}-6 \\
-3\end{array}$ \\
\hline Missouri. & 5,844 & 3,656 & 2,188 & Pacific ......... & 506 & 263 & 243 \\
\hline $\begin{array}{l}\text { North Dakota..- } \\
\text { South Dakota... }\end{array}$ & $\begin{array}{l}10 \\
40\end{array}$ & $\begin{array}{l}22 \\
67\end{array}$ & $\begin{array}{l}-12 \\
-27\end{array}$ & Washington & 73 & 77 & -1 \\
\hline Nebraska & 38 & 96 & -58 & $\begin{array}{l}\text { Oregon } \\
\text { California }\end{array}$ & $\begin{array}{r}9 \\
424\end{array}$ & $\begin{array}{r}27 \\
159\end{array}$ & $\begin{array}{r}-18 \\
26.5\end{array}$ \\
\hline Kansas & 941 & 1,532 & -591 & & & & \\
\hline
\end{tabular}

Twenty years of acreage losses.-Twenty years ago at the census of 1910 , as shown by Table 21, and prior to the requirement by industry of an enlarged source of labor supply within the United States, Negro farmers operated $42,279,510$ acres, or approximately 66,062 square miles, an area greater than the combined land area $(65,756)$ of Massachusetts, New Jersey, Maryland, and Virginia. By 1930 this Negro-operated farm land had been reduced by 4,682,378 acres, or 7,316 square miles, an area almost as large as the State of New Jersey, a decrease of 847,328 acres having been reported for the 10-year period 1910 to 1920 , and one of $3,835,050$ acres between 1920 and 1930, the three States (Alabama, Georgia, and South Carolina) having contributed nearly 79 per cent of the total decrease. Only 13 States reported farm acreage increases, Vermont, Wisconsin, Minnesota, Missouri, North Carolina, Louisiana, Texas, Montana, Idaho, Wyoming, New Mexico, Arizona, and Washington. 
Table 21.-Land in Farms Operated by Negroes, 1930 and 1910, With Increase During the 20-Year Period, 1910 to 1930, by Sections, Divisions, and States

[A minus sign ( - ) denotes decrease]

\begin{tabular}{|c|c|c|c|c|}
\hline \multirow{3}{*}{ SECTION, DIVISION, AND STATE } & \multicolumn{4}{|c|}{ LAND IN FARMS (ACRES) } \\
\hline & \multirow{2}{*}{1930} & \multirow{2}{*}{1910} & \multicolumn{2}{|c|}{ Increase, $1910-1930$} \\
\hline & & & Number & Per cent \\
\hline United States. & $57,597,132$ & $42,279,510$ & $-4,682,378$ & -11.1 \\
\hline $\begin{array}{l}\text { The North } \\
\text { The South } \\
\text { The West. }\end{array}$ & $\begin{array}{r}720,872 \\
36,758,484 \\
117,776 \\
\end{array}$ & $\begin{array}{r}868,630 \\
41,284,471 \\
126,409\end{array}$ & $\begin{array}{r}-147,758 \\
-4,525,987 \\
-8,633\end{array}$ & $\begin{array}{r}-17.0 \\
-11.0 \\
-6.8\end{array}$ \\
\hline New England.. & 9,397 & 14,759 & $-5,362$ & -36.3 \\
\hline $\begin{array}{l}\text { Maine-1 } \\
\text { Vew Hampshire } \\
\text { Massachusetts... } \\
\text { Rhode Island } \\
\text { Connecticut }\end{array}$ & $\begin{array}{r}818 \\
814 \\
3,812 \\
2,063 \\
571 \\
1,319\end{array}$ & $\begin{array}{r}1,280 \\
923 \\
1,917 \\
3,535 \\
1,664 \\
5,440\end{array}$ & $\begin{array}{r}-462 \\
-109 \\
1,895 \\
-1,472 \\
-1,093 \\
-4,121\end{array}$ & $\begin{array}{r}-36.1 \\
-11.8 \\
98.9 \\
-41.6 \\
-65.7 \\
-75.8\end{array}$ \\
\hline Middle Atlantic....... & 55,808 & 74,849 & $-19,041$ & -25.4 \\
\hline $\begin{array}{l}\text { New York } \\
\text { New Jersey } \\
\text { Pennsylvania. }\end{array}$ & $\begin{array}{l}14,894 \\
19,298 \\
21,616\end{array}$ & $\begin{array}{l}22,552 \\
22,200 \\
30,097\end{array}$ & $\begin{array}{l}-7,658 \\
-2,902 \\
-8,481\end{array}$ & $\begin{array}{l}-34.0 \\
-13.1 \\
-28.2\end{array}$ \\
\hline East North Central & 214,596 & 287,513 & $-72,917$ & -25.4 \\
\hline $\begin{array}{l}\text { Ohio } \\
\text { Indiana } \\
\text { Michigan } \\
\text { Wisconsin }\end{array}$ & $\begin{array}{r}92,083 \\
28,454 \\
57,805 \\
30,959 \\
5,295\end{array}$ & $\begin{array}{r}106,742 \\
43,627 \\
87,784 \\
45,331 \\
4,029\end{array}$ & $\begin{array}{r}-14,659 \\
-15,173 \\
-29,979 \\
-14,372 \\
1,266\end{array}$ & $\begin{array}{r}-13.7 \\
-34.8 \\
-34.2 \\
-31.7 \\
31.4\end{array}$ \\
\hline West North Central & 441,071 & 491,509 & $-50,438$ & -10.3 \\
\hline $\begin{array}{l}\text { Minnesota } \\
\text { Iowa } \\
\text { Missourí } \\
\text { North Dakota. } \\
\text { South Dakota. } \\
\text { Nebraska } \\
\text { Kansas. }\end{array}$ & $\begin{array}{r}2,692 \\
10,002 \\
255,623 \\
2,565 \\
14,228 \\
9,216 \\
146,745\end{array}$ & $\begin{array}{r}2,362 \\
13,617 \\
229,255 \\
5,484 \\
20,753 \\
36,585 \\
183,453\end{array}$ & $\begin{array}{r}330 \\
-3,615 \\
26,368 \\
-2,919 \\
-6,525 \\
-27,369 \\
-36,708\end{array}$ & $\begin{array}{r}14.0 \\
-26.5 \\
11.5 \\
-53.2 \\
-31.4 \\
-74.8 \\
-20.0\end{array}$ \\
\hline South Atlantic & $14,550,451$ & $17,605,488$ & $-3,055,037$ & -17.4 \\
\hline $\begin{array}{l}\text { Delaware. } \\
\text { Daryland } \\
\text { Virgict of Columbia } \\
\text { West Virginia } \\
\text { North Carolina } \\
\text { South Carolina } \\
\text { Georgia.. } \\
\text { Florida }\end{array}$ & $\begin{array}{r}54,756 \\
345,224 \\
95 \\
2,039,656 \\
28,013 \\
3,296,445 \\
3,167,898 \\
5,104,452 \\
513,912\end{array}$ & $\begin{array}{r}56,973 \\
358,509 \\
95 \\
2,233,883 \\
34,520 \\
3,121,827 \\
3,939,592 \\
7,091,949 \\
768,140\end{array}$ & $\begin{array}{r}-2,217 \\
-13,285 \\
-194,227 \\
-6,507 \\
174,618 \\
-771,694 \\
-1,987,497 \\
-254,228\end{array}$ & $\begin{array}{r}-3.9 \\
-3.7 \\
-8.7 \\
-18.8 \\
5.6 \\
-19.6 \\
-28.0 \\
-33.1\end{array}$ \\
\hline East South Central & $11,918,057$ & $13,573,980$ & $-1,655,923$ & -12.2 \\
\hline $\begin{array}{l}\text { Kentucky } \\
\text { Tennessee. } \\
\text { Alabama } \\
\text { Mississippi. }\end{array}$ & $\begin{array}{r}341,833 \\
1,356,683 \\
4,157,051 \\
6,062,490\end{array}$ & $\begin{array}{r}439,657 \\
1,605,694 \\
5,083,552 \\
6,445,077\end{array}$ & $\begin{array}{l}-97,824 \\
-249,011 \\
-926,501 \\
-382,587\end{array}$ & $\begin{array}{r}-22.3 \\
-15.5 \\
-18.2 \\
-5.9\end{array}$ \\
\hline West South Central & $10,289,976$ & $10,105,003$ & 184,973 & 1.8 \\
\hline $\begin{array}{l}\text { Arkansas. } \\
\text { Louisiana. } \\
\text { Oklahoma } \\
\text { Texas. }\end{array}$ & $\begin{array}{l}2,485,626 \\
2,313,338 \\
1,061,341 \\
4,429,671\end{array}$ & $\begin{array}{l}2,652,684 \\
2,121,258 \\
1,066,863 \\
4,264,198\end{array}$ & $\begin{array}{r}-167,058 \\
192,080 \\
-5,522 \\
165,473\end{array}$ & $\begin{array}{r}-6.3 \\
9.1 \\
-0.5 \\
3.9\end{array}$ \\
\hline $\begin{array}{l} \\
\end{array}$ & 77,228 & 62,807 & 14,421 & 23.0 \\
\hline $\begin{array}{l}\text { Montana } \\
\text { Idaho } \\
\text { Wyoming } \\
\text { Nolorado } \\
\text { New Mexico } \\
\text { Arizona } \\
\text { Utah } \\
\text { Nevada. }\end{array}$ & $\begin{array}{r}9,804 \\
2,816 \\
10,925 \\
25,137 \\
19,883 \\
7,766 \\
37 \\
860\end{array}$ & $\begin{array}{r}7,918 \\
1,043 \\
6,202 \\
32,003 \\
11,633 \\
1,222 \\
506 \\
2,280\end{array}$ & $\begin{array}{r}1,886 \\
1,773 \\
4,723 \\
-6,866 \\
8,250 \\
6,544 \\
-469 \\
-1,420\end{array}$ & $\begin{array}{r}23.8 \\
170.0 \\
76.2 \\
-21.5 \\
70.9 \\
535.5 \\
-92.7 \\
-62.3\end{array}$ \\
\hline Pacific_ & 40,548 & 63,602 & $-23,054$ & -36.2 \\
\hline $\begin{array}{l}\text { Washington } \\
\text { Oregon } \\
\text { California }\end{array}$ & $\begin{array}{r}9,425 \\
826 \\
30,297\end{array}$ & $\begin{array}{r}7,651 \\
3,021 \\
52,930\end{array}$ & $\begin{array}{r}1,774 \\
-2,195 \\
-22,633\end{array}$ & $\begin{array}{r}23.2 \\
-72.7 \\
-42.8\end{array}$ \\
\hline
\end{tabular}


Value of land and buildings.-During the 20 years, 1910 to 1930 , there was an increase of $\$ 480,228,096$, or 52 per cent, as shown by Table 22 , in the value of land and buildings operated by Negro farmers. This increase reported for 1930 indicated that farm values were at higher levels than at the census of 1910, but below the inflated values of 1920 , a condition that is further emphasized by the fact that during the same 20-year period, as shown in Tables 20 and 21, there was a reduction in the number of Negro farmers and also in the acres of land in farms operated by them. The North reported a decrease of $\$ 3,588,166$, or 7.9 per cent; the South an increase of $\$ 481,599,257$, or 55.1 per cent, and the West an increase of $\$ 2,217,005$, or 57.2 per cent.

Seven States in the North, including Maine, Vermont, Massachusetts, New Jersey, Wisconsin, Minnesota, and Missouri reported increases during the 20years, 1910 to 1930 . In the South all except Georgia and the District of Columbia reported increases, and in the West the States of Colorado, Utah, Nevada, Washington, and Oregon reported lesser values, the total of which failed, however, to counterbalance the total increase of the seven other States composing the territory denominated as the West. In the North the greatest increase in amount, but not in the percentage increase, was made by Missouri. Of the States in the South, Mississippi followed by Texas reported the greatest increases in values but Louisiana and North Carolina showed the greatest percentage increases. In the West, California outstripped the other States in the amount of increased values for the 20 years covered by this table.

Table 22.-VAlue of Land and Buildings of Farms Operated by Negroes, 1930 and 1910, With Increase During the 20-Year Period, 1910 to 1930, by Sections, Divisions, and States

[A minus sign (-) denotes decrease]

\begin{tabular}{|c|c|c|c|c|}
\hline \multirow{3}{*}{ SECTION, DIVISION, AND STATE } & \multicolumn{4}{|c|}{ VALUE OF LAND AND BUILDINGS } \\
\hline & \multirow{2}{*}{1930} & \multirow{2}{*}{1910} & \multicolumn{2}{|c|}{ Increase, $1910-1930$} \\
\hline & & & Amount & Per cent \\
\hline United States........... & $81,402,945,799$ & $\$ 922,717,703$ & $8480,228,098$ & 52.0 \\
\hline $\begin{array}{l}\text { The North } \\
\text { The South } \\
\text { The West }\end{array}$ & $\begin{array}{r}41,668,222 \\
1,355,181,667 \\
6,095,910 \\
\end{array}$ & $\begin{array}{r}45,256,388 \\
873,582,410 \\
3,878,905 \\
\end{array}$ & $\begin{array}{r}-3,588,166 \\
481,599,257 \\
2,217,005 \\
\end{array}$ & $\begin{array}{r}-7.9 \\
55.1 \\
57.2 \\
\end{array}$ \\
\hline New England. & 909,395 & 802,360 & 107,035 & 13.3 \\
\hline $\begin{array}{l}\text { Maine } \\
\text { New Hampshire } \\
\text { Vermont. } \\
\text { Massachusetts. } \\
\text { Rhode Island } \\
\text { Connecticut... }\end{array}$ & $\begin{array}{r}41,400 \\
18,000 \\
118,700 \\
376,595 \\
40,000 \\
314,700\end{array}$ & $\begin{array}{r}36,850 \\
61,300 \\
42,350 \\
258,065 \\
62,600 \\
341,195\end{array}$ & $\begin{array}{r}4,550 \\
-43,300 \\
76,350 \\
118,530 \\
-22,600 \\
-26,495\end{array}$ & $\begin{array}{r}12.3 \\
-70.6 \\
180.3 \\
45.9 \\
-36.1 \\
-7.8\end{array}$ \\
\hline 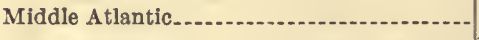 & $5,140,255$ & $5,299,347$ & $-159,092$ & -3.0 \\
\hline $\begin{array}{l}\text { New York } \\
\text { New Jersey }\end{array}$ & $\begin{array}{r}875,575 \\
2,070,400 \\
2,194,280\end{array}$ & $\begin{array}{l}1,234,530 \\
1,689,737 \\
2,375,030\end{array}$ & $\begin{array}{r}-358,955 \\
380,663 \\
-180,800\end{array}$ & $\begin{array}{r}-29.1 \\
22.5 \\
-7.6\end{array}$ \\
\hline East North Central & $13,304,751$ & $17,477,649$ & $-4,172,898$ & -23.9 \\
\hline $\begin{array}{l}\text { Ohio } \\
\text { Indiana } \\
\text { Illinois } \\
\text { Michlgan } \\
\text { Wisconsin. }\end{array}$ & $\begin{array}{r}5,434,735 \\
1,947,915 \\
3,704,618 \\
1,874,378 \\
343,105\end{array}$ & $\begin{array}{r}5,989,075 \\
3,317,747 \\
5,972,592 \\
2,024,685 \\
173,550\end{array}$ & $\begin{array}{r}-554,340 \\
-1,369,832 \\
-2,267,974 \\
-150,307 \\
169,555\end{array}$ & $\begin{array}{r}-9.3 \\
-41.3 \\
-38.0 \\
-7.4 \\
97.7\end{array}$ \\
\hline
\end{tabular}


Table 22.-Value of Land and Buildings of Farms Operated by Negroes, 1930 and 1910, With Increase During the 20-Year Period, 1910 to 1930, BY Sections, Divisions, and States-Continued

\begin{tabular}{|c|c|c|c|c|}
\hline \multirow{3}{*}{ SECTION, DIVISION, AND STATE } & \multicolumn{4}{|c|}{ VALUE OF LAND AND BUILDINGS } \\
\hline & \multirow{2}{*}{1930} & \multirow{2}{*}{1910} & \multicolumn{2}{|c|}{ Increase, 1910-1930 } \\
\hline & & & Amount & Per cent \\
\hline West North Central & $\$ 22,313,821$ & $\$ 21,677,032$ & $\$ 636,789$ & 2.9 \\
\hline $\begin{array}{l}\text { Minnesota } \\
\text { Iowa } \\
\text { Missouri } \\
\text { North Dakota. } \\
\text { South Dakota.... } \\
\text { Nebraska } \\
\text { Kansas. }\end{array}$ & $\begin{array}{r}187,325 \\
878,234 \\
14,498,297 \\
62,700 \\
285,425 \\
308,080 \\
6,093,760\end{array}$ & $\begin{array}{r}123,915 \\
1,054,495 \\
12,006,443 \\
154,100 \\
507,405 \\
513,360 \\
7,317,314\end{array}$ & $\begin{array}{r}63,410 \\
-176,261 \\
2,491,854 \\
-91,400 \\
-221,980 \\
-205,280 \\
-1,223,554\end{array}$ & $\begin{array}{r}51.2 \\
-16.7 \\
20.8 \\
-59.3 \\
-43.7 \\
-40.0 \\
-16.7\end{array}$ \\
\hline South Atlantic... & $484,443,943$ & $365,068,245$ & $119,375,698$ & 32.7 \\
\hline 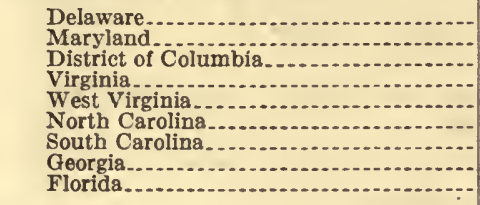 & $\begin{array}{r}2,628,590 \\
18,896,282 \\
82,000 \\
71,722,401 \\
1,480,628 \\
153,882,635 \\
105,693,220 \\
114,688,230 \\
15,369,957\end{array}$ & $\begin{array}{r}1,981,716 \\
10,267,284 \\
89,400 \\
45,143,291 \\
1,075,204 \\
66,793,591 \\
98,966,444 \\
128,877,032 \\
11,874,283\end{array}$ & $\begin{array}{r}646,874 \\
8,628,998 \\
-7,400 \\
26,579,110 \\
405,424 \\
87,089,044 \\
6,726,776 \\
-14,188,802 \\
3,495,674\end{array}$ & $\begin{array}{r}32.6 \\
84.0 \\
-8.3 \\
58.9 \\
37.7 \\
130.4 \\
6.8 \\
-11.0 \\
29.4\end{array}$ \\
\hline East South Central. & $426,528,844$ & $279,431,194$ & $147,097,650$ & 52.6 \\
\hline $\begin{array}{l}\text { Kentucky } \\
\text { Tennessee.......... } \\
\text { Alabama } \\
\text { Mississippi........... }\end{array}$ & $\begin{array}{r}16,157,593 \\
56,339,610 \\
104,726,209 \\
249,305,432\end{array}$ & $\begin{array}{r}15,017,228 \\
42,183,226 \\
73,834,072 \\
148,396,668\end{array}$ & $\begin{array}{r}1,140,365 \\
14,156,384 \\
30,892,137 \\
100,908,764\end{array}$ & $\begin{array}{r}7.6 \\
33.6 \\
41.8 \\
68.0\end{array}$ \\
\hline West South Centra]_ & $444,208,880$ & $229,082,971$ & $215,125,909$ & 93.9 \\
\hline $\begin{array}{l}\text { Arkansas. } \\
\text { Louisiana } \\
\text { Oklahoma } \\
\text { Texas }\end{array}$ & $\begin{array}{r}118,180,961 \\
108,668,818 \\
37,967,113 \\
179,391,988\end{array}$ & $\begin{array}{l}68,978,464 \\
44,891,918 \\
24,552,515 \\
90,660,074\end{array}$ & $\begin{array}{l}49,202,497 \\
63,776,900 \\
13,414,598 \\
88,731,914\end{array}$ & $\begin{array}{r}71.3 \\
142.1 \\
54.6 \\
97.9\end{array}$ \\
\hline Mountain.... & $2,037,510$ & $1,155,995$ & 881,515 & 76.3 \\
\hline $\begin{array}{l}\text { Montana } \\
\text { Idaho } \\
\text { Wyoming } \\
\text { Colorado } \\
\text { New Mexico } \\
\text { Arizona } \\
\text { Utah } \\
\text { Nevada }\end{array}$ & $\begin{array}{r}115,084 \\
107,200 \\
139,020 \\
445,540 \\
400,956 \\
761,510 \\
24,200 \\
44,000\end{array}$ & $\begin{array}{r}114,680 \\
54,250 \\
129,200 \\
477,520 \\
199,245 \\
30,100 \\
80,500 \\
70,500\end{array}$ & $\begin{array}{r}404 \\
52,950 \\
9,820 \\
-31,980 \\
201,711 \\
731,410 \\
-56,300 \\
-26,500\end{array}$ & $\begin{array}{r}0.4 \\
97.6 \\
7.6 \\
-6.7 \\
101.2 \\
2,429.9 \\
-69.9 \\
-37.6\end{array}$ \\
\hline Pacific................ & $4,058,400$ & $2,722,910$ & $1,335,490$ & 49.0 \\
\hline $\begin{array}{l}\text { Washington } \\
\text { Oregon } \\
\text { California }\end{array}$ & $\begin{array}{r}356,705 \\
32,420 \\
3,669,275\end{array}$ & $\begin{array}{r}470,625 \\
151,350 \\
2,100,935\end{array}$ & $\begin{array}{l}-113,920 \\
-118,930 \\
1,568,340\end{array}$ & $\begin{array}{r}-24.2 \\
-78.6 \\
74.6\end{array}$ \\
\hline
\end{tabular}

Tenure by racial class.-Data on the number of farmers by tenure and racial class, and the per cent distribution by tenure of each of these groups are presented in Table 23. Of the 882,850 Negro farmers, 181,016, or 20.5 per cent, were owners as compared with 77 per cent of the Indian, 16.3 per cent of the other colored, and 62.6 per cent of the white farmers. The 700,911 Negro tenant farmers constituted 79.4 per cent of all farmers of that racial class as against a 22.7 per cent tenancy for Indians, a 50.4 for the other colored, and one of 36.4 per cent for the white farm operators. Managers numbered 55,889 of whom 923 were Negroes, 68 Indians, 2,131 other colored, and 52,767 white.

In the South, 176,130 , or 20.2 per cent, of the Negroes, 5,850 , or 55 per cent, of the Indians, and 1,233,656, or 52.7 per cent, of the whites owned the farms they were operating, while 694,001 , or 79.7 per cent, of the Negroes, 4,766 , or 44.8 per

$$
130058-33-5
$$


cent, of the Indians, and $1,091,944$, or 46.6 per cent, of the white farmers were reported as tenants. "Of the 17,358 farm managers in the South, 805 were Negroes, 21 Indians, and 16,529 white. Excluding Negroes and Indians there were only 114 nonwhite farm operators in the South.

In the North, where Negraes form only 3.3 per cent of the total population, only 1.2 per cent of the rural population and operate less than one-half of 1 per cent of the farms, tenure conditions are somewhat different than in the South. Due to a higher percentage of ownership for Negro, Indian, and white farm operators, tenancy falls to lower levels. Negroes owned 4,424, or 39.8 per cent, were tenants on 6,588 , or 59.3 per cent, and managed slightly less than 1 per cent of the 11,104 farms operated by them in the North. Less than 100 nonwhite farmers, exclusive of Negroes and Indians, operated in the North.

Although few in number, Negro farmers in the West owned 57 per cent, operated as tenants 39.8 per cent, and were managers of 3.2 per cent of the 810 farms reported for them in that section of the country. The percentage ownership for Negro, Indian, and white farmers was greater in the West than in the South or North, and it is in this section that nearly 97 per cent (96.7) of the total number of colored farmers, other than Negroes and Indians, operate.

Table 23. - Number of Farm Operators, by Color and Tenure, by Sections, 1930

\begin{tabular}{|c|c|c|c|c|c|c|c|c|c|}
\hline \multirow{3}{*}{ TENURE } & \multicolumn{9}{|c|}{ FARM OPERATORS } \\
\hline & \multirow{2}{*}{ Total } & \multirow{2}{*}{ Negro } & \multirow{2}{*}{ Indian } & \multirow{2}{*}{$\begin{array}{l}\text { Other } 1 \\
\text { colored }\end{array}$} & \multirow{2}{*}{ White 2} & \multicolumn{4}{|c|}{ Per cent distribution } \\
\hline & & & & & & Negro & Indian & $\begin{array}{l}\text { Other } \\
\text { colored }\end{array}$ & White \\
\hline \multirow{4}{*}{ 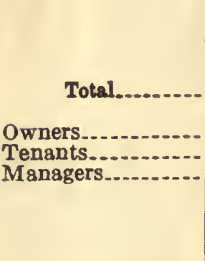 } & \multicolumn{9}{|c|}{ UNTTED STATES } \\
\hline & $6,288,648$ & 882,850 & 26,817 & 6,403 & $6,372,578$ & 100.0 & 100.0 & 100.0 & 100.0 \\
\hline & $\begin{array}{r}3,568,394 \\
2,664,365 \\
55,889\end{array}$ & $\begin{array}{r}181,016 \\
700,911 \\
923\end{array}$ & $\begin{array}{r}20,658 \\
6,091 \\
68\end{array}$ & $\begin{array}{l}1,046 \\
3,226 \\
2,131\end{array}$ & $\begin{array}{r}3,365,674 \\
1,954,137 \\
52,767\end{array}$ & $\begin{array}{r}20.5 \\
79.4 \\
0.1\end{array}$ & $\begin{array}{r}77.0 \\
22.7 \\
0.3\end{array}$ & $\begin{array}{l}16.3 \\
50.4 \\
33.3\end{array}$ & $\begin{array}{l}62.6 \\
36.4 \\
.1 .0\end{array}$ \\
\hline & \multicolumn{9}{|c|}{ THE SOUTH } \\
\hline \multirow{3}{*}{ 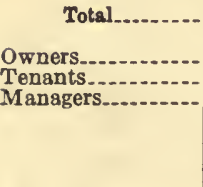 } & $3,228,816$ & 870,838 & 10,687 & 114 & $2,342,129$ & 100.0 & 100.0 & 100.0 & 100.0 \\
\hline & $\begin{array}{r}1,415,675 \\
1,790,783 \\
17,358\end{array}$ & $\begin{array}{r}176,130 \\
694,001 \\
805\end{array}$ & $\begin{array}{r}5,850 \\
4,766 \\
21\end{array}$ & $\begin{array}{r}39 \\
72 \\
3\end{array}$ & $\begin{array}{r}1,233,658 \\
1,091,944 \\
16,529\end{array}$ & $\begin{array}{r}20.2 \\
79.7 \\
0.1\end{array}$ & $\begin{array}{r}55.0 \\
44.8 \\
0.2\end{array}$ & $\begin{array}{r}34.2 \\
63.2 \\
2.6\end{array}$ & $\begin{array}{r}52.7 \\
46.6 \\
0.7\end{array}$ \\
\hline & \multicolumn{9}{|c|}{ THE NORTH } \\
\hline Total...... & $2,561,785$ & 11,104 & 4,758 & 99 & $2,545,829$ & 100.0 & 100.0 & 100.0 & 100.0 \\
\hline \multirow[t]{2}{*}{$\begin{array}{l}\text { Owners } \\
\text { Tenants... } \\
\text { Managers }\end{array}$} & $\begin{array}{r}1,768,206 \\
768,486 \\
25,093\end{array}$ & $\begin{array}{r}4,424 \\
B, 588 \\
92\end{array}$ & $\begin{array}{r}3,929 \\
807 \\
17\end{array}$ & $\begin{array}{r}35 \\
64 \\
-\end{array}$ & $\begin{array}{r}1,759,818 \\
761,027 \\
24,984\end{array}$ & $\begin{array}{r}39.8 \\
59.3 \\
0.8\end{array}$ & $\begin{array}{r}82.7 \\
17.0 \\
0.4\end{array}$ & $\begin{array}{r}35.4 \\
64.6 \\
\end{array}$ & $\begin{array}{r}69.1 \\
29.9 \\
1.0\end{array}$ \\
\hline & \multicolumn{9}{|c|}{ THE WEST } \\
\hline Total....... & 508,047 & 810 & 11,427 & 6, 180 & 484,620 & 100.0 & 100.0 & 100.0 & 100.0 \\
\hline $\begin{array}{l}\text { Owners_... } \\
\text { Tenants_... } \\
\text { Managers........ }\end{array}$ & $\begin{array}{r}384,513 \\
105,096 \\
13,438\end{array}$ & $\begin{array}{r}462 \\
322 \\
26\end{array}$ & $\begin{array}{r}10,879 \\
518 \\
30\end{array}$ & $\begin{array}{r}972 \\
3,090 \\
2,128\end{array}$ & $\begin{array}{r}372,200 \\
101,166 \\
11,254\end{array}$ & $\begin{array}{r}57.0 \\
39.8 \\
3.2\end{array}$ & $\begin{array}{r}95.2 \\
4.5 \\
0.3\end{array}$ & $\begin{array}{l}15.7 \\
49.9 \\
34.4\end{array}$ & $\begin{array}{r}76.8 \\
20.9 \\
2.3\end{array}$ \\
\hline
\end{tabular}

1 Includes 5,840 Japanese, 476 Chinese, 56 Filipinos, 30 Koreans, and 1 Hawaiian.

Includes Mexicans and Hindus. 


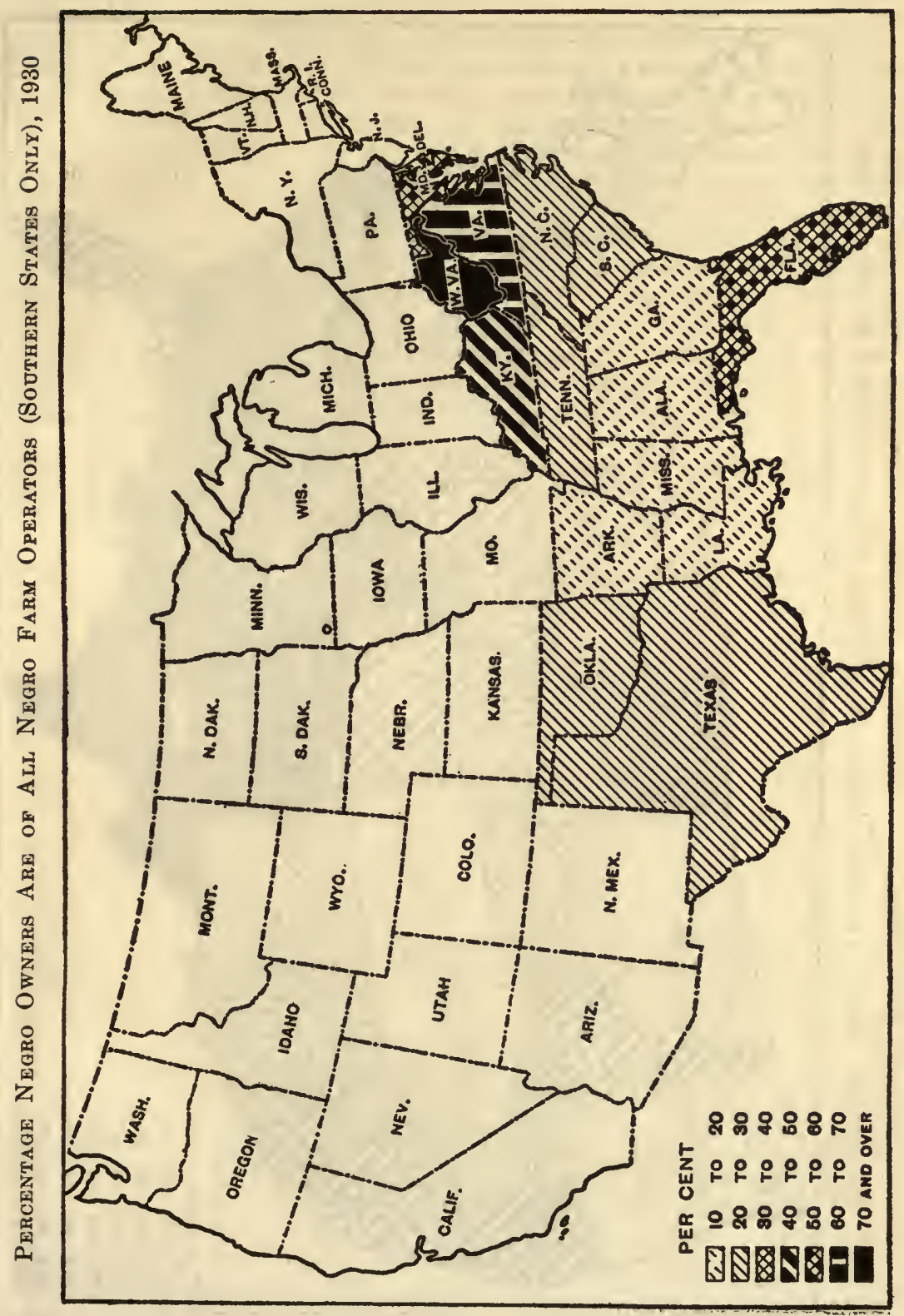




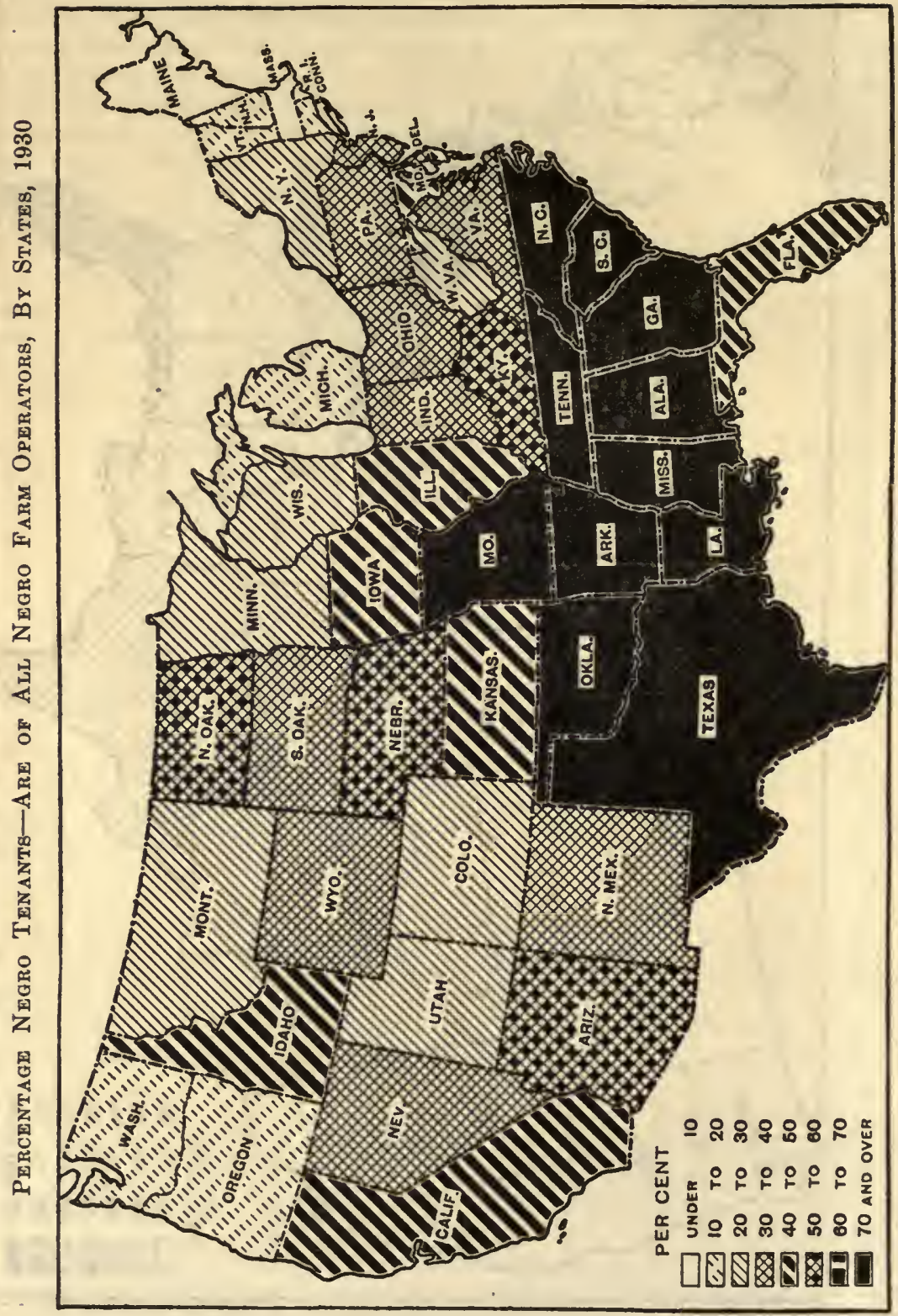


Changes in tenure.-In Table 24 statistics are given for the United States showing the changes by tenure of Negro and white farmers, and the changes in the South, the North, and the West for Negro farm operators as reported at the censuses of 1910,1920 , and 1930 .

Between 1910 and 1920 there was a net increase of 32,338 Negro farm operators. There was a loss of 360 owners but an increase of 32,106 tenants and 592 managers. During the same 10 years white farm operators increased by 57,835 , with a loss of 15,633 owners accompanied by an increase of 63,805 tenants and 9,663 managers. From 1920 to 1930 there was a decrease of 42,858 Negro farmers in the United States. The number of owners decreased 37,596; tenants 4,159 and managers 1,103. Eight States, in the order named, South Carolina, Virginia, Georgia, Arkansas, Texas, North Carolina, Tennessee, and Oklahoma having contributed 31,362 , or 83.4 per cent (see Table 35 ) to the largest decrease in Negro farm ownership recorded since the first classification of Negro farm operators by tenure was made, at the census of 1900 . The decrease in the number of Negro farm owners during the 10 years 1920 to 1930 amounted to 17.2 per cent as compared with a decrease of 8.8 per cent for white owners, but there was a large increase of white tenant farmers as compared with a loss of Negro tenant operators:

Table 24.-NUMber of Negro aNd White Farm Operators in The UNited States, by Tendre, and Number of Negro Farm Operators, by Tendre, BY Sections: 1930, 1920, AND 1910

[A minus sign (-) denotes decrease]

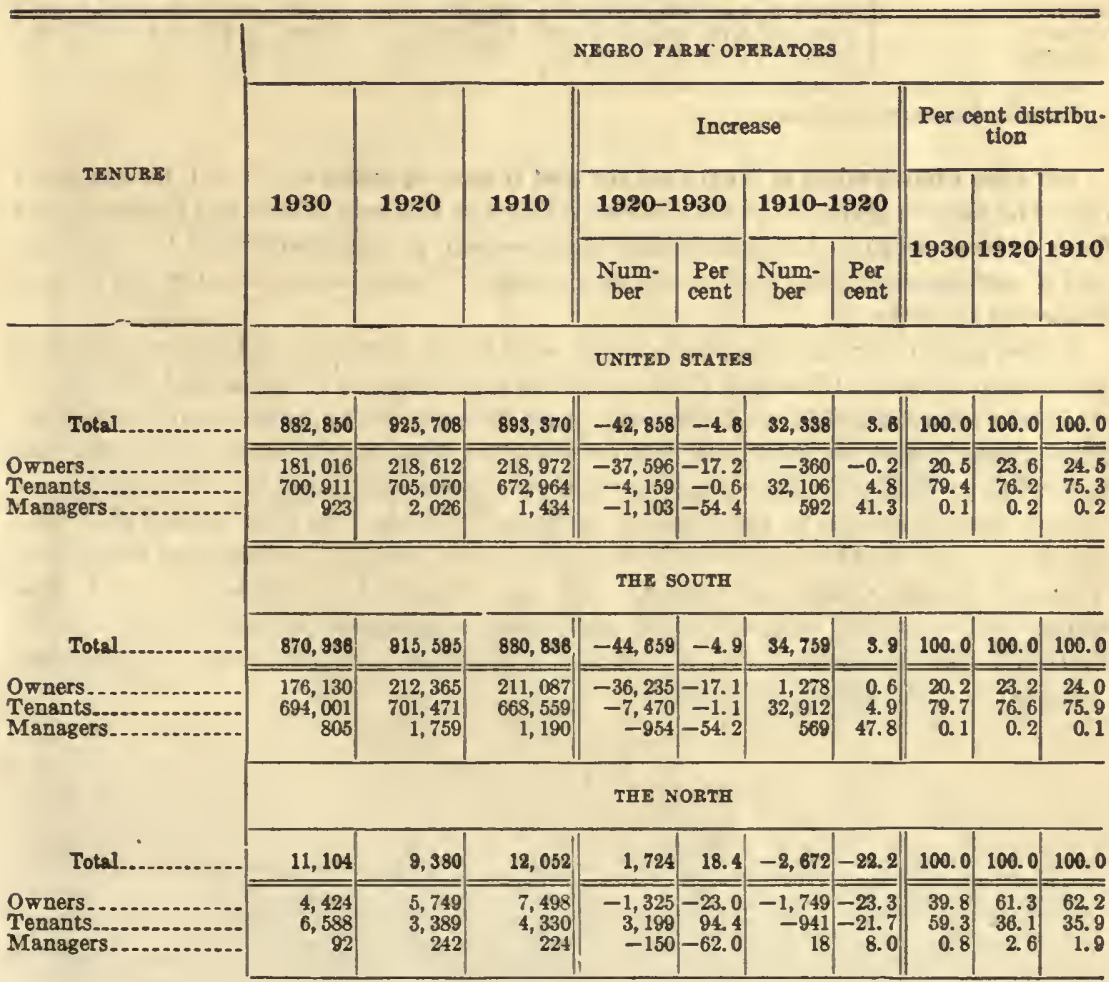


Table 24.-Number of Negro and White Farm Operators in the United States, by Tendre, and Number of Negro Farm Operators, by Tendre, By SeCtions: 1930,1920 , AND 1910-Continued

\begin{tabular}{|c|c|c|c|c|c|c|c|c|c|c|}
\hline \multirow{4}{*}{ TENURE } & \multicolumn{10}{|c|}{ NEGRO TARM OPERATORS-Continued } \\
\hline & \multirow{3}{*}{1930} & \multirow{3}{*}{1920} & \multirow{3}{*}{1910} & \multicolumn{4}{|c|}{ Increase } & \multicolumn{3}{|c|}{$\underset{\text { tion }}{\text { Per cent distribu- }}$} \\
\hline & & & & \multicolumn{2}{|c|}{$1920-1930$} & \multicolumn{2}{|c|}{$1910-1920$} & \multirow{2}{*}{1930} & \multirow{2}{*}{1920} & \multirow{2}{*}{1910} \\
\hline & & & & Num- & $\begin{array}{l}\text { Per } \\
\text { cent }\end{array}$ & Num- & $\begin{array}{l}\text { Per } \\
\text { cent }\end{array}$ & & & \\
\hline & \multicolumn{10}{|c|}{ THE WEST } \\
\hline Total... & 810 & 738 & 482 & 77 & 10.5 & 251 & 52.1 & 100.0 & 100.0 & 100.0 \\
\hline $\begin{array}{l}\text { Owners } \\
\text { Tenants. } \\
\text { Managers }\end{array}$ & $\begin{array}{r}462 \\
322 \\
26\end{array}$ & $\begin{array}{r}498 \\
210 \\
25\end{array}$ & $\begin{array}{r}387 \\
75 \\
20\end{array}$ & $\begin{array}{r}-36 \\
112 \\
1\end{array}$ & $\begin{array}{r}-7.2 \\
53.3 \\
4.0 \\
\end{array}$ & $\begin{array}{r}111 \\
135 \\
5\end{array}$ & $\begin{array}{r}28.7 \\
180.0 \\
25.0\end{array}$ & $\begin{array}{r}57.0 \\
39.8 \\
3.2\end{array}$ & $\begin{array}{r}67.9 \\
28.6 \\
3.4\end{array}$ & $\begin{array}{r}80.3 \\
15.6 \\
4.1\end{array}$ \\
\hline$\sqrt{1}$ & \multicolumn{10}{|c|}{ WHITE FARM OPERATORS IN THE UNITED STATES } \\
\hline Total 1 ... & $5,372,578$ & $5,498,454$ & $6,440,818$ & $-125,878$ & -2.3 & 57,895 & 1.1 & 100.0 & 100.0 & 100.0 \\
\hline $\begin{array}{l}\text { Owners } \\
\text { Tenants... } \\
\text { Managers... }\end{array}$ & $\begin{array}{r}3,365,674 \\
1,954,137 \\
62,767\end{array}$ & $\begin{array}{r}3,691,868 \\
1,740,363 \\
66,223\end{array}$ & $\begin{array}{r}3,707,501 \\
1,676,558 \\
56,560\end{array}$ & $\begin{array}{r}-326,194 \\
213,774 \\
-13,456\end{array}$ & $\begin{array}{r}-8.8 \\
12.3 \\
-20.3\end{array}$ & $\begin{array}{r}-15,633 \\
63,805 \\
9,663\end{array}$ & $\begin{array}{r}-0.4 \\
3.8 \\
17.1\end{array}$ & \begin{tabular}{r|}
62.6 \\
36.4 \\
1.0
\end{tabular} & \begin{tabular}{r|}
67.1 \\
31.7 \\
1.2
\end{tabular} & $\begin{array}{r}68.1 \\
30.8 \\
1.0\end{array}$ \\
\hline
\end{tabular}

1 Includes Mexicans and Hindus.

Per cent distribution of Negro owner and tenant operators. - It will be apparent from the figures given in Table 25 that there was a steady decrease at each census from 1910 to 1930 in the percentage of ownership of farms operated by Negroes, and a corresponding increase in the percentage of tenant operators for the United States as a whole.

In the group of Southern States there were slight increases in the percentage of ownership between 1920 and 1930 for Delaware, Georgia, Florida, and Kentucky, while Delaware, Florida, and Alabama were the only States in the South where the percentage Negro ownership in 1930 was higher than at the census of 1910 . As indicated in Table 35, Delaware was the only Southern State in which there was even a small increase in the number of Negro owners. In this same Table (35) it will be noted that the number of both owners and tenants decreased in Maryland, Virginia, South Carolina, Georgia, Florida, Kentucky, Tennessee, and Alabama and that the number of Negro tenants increased in only seven of the Southern States, namely-West Virginia, North Carolina, Mississippi, Arkansas, Louisiana, Oklahoma, and Texas. 
Table 25.-Per Cent Distribution of Owned and Tenant Farms Operated by Negroes, by Sections and States: 1930, 1920, and 1910

\begin{tabular}{|c|c|c|c|c|c|c|}
\hline \multirow{3}{*}{ SECTION AND STATE } & \multicolumn{6}{|c|}{ PER CENT OF TOTAL REPORTED AS- } \\
\hline & \multicolumn{3}{|c|}{ Owners } & \multicolumn{3}{|c|}{ Tenants } \\
\hline & 1930 & 1920 & 1910 & 1930 & 1920 & 1910 \\
\hline 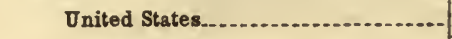 & 20.5 & 23.6 & 24.6 & 79.4 & 76.2 & 75.3 \\
\hline $\begin{array}{l}\text { The North } \\
\text { The South } \\
\text { The West }\end{array}$ & $\begin{array}{l}39.8 \\
20.2 \\
57.0\end{array}$ & $\begin{array}{l}61.3 \\
23.2 \\
67.9\end{array}$ & $\begin{array}{l}62.2 \\
24.0 \\
80.3\end{array}$ & $\begin{array}{l}59.3 \\
79.7 \\
39.8\end{array}$ & $\begin{array}{l}36.1 \\
76.6 \\
28.6\end{array}$ & $\begin{array}{l}35.9 \\
75.9 \\
15.6\end{array}$ \\
\hline $\begin{array}{l}\text { NEW ENGLAND: } \\
\text { Maine } \\
\text { New Hampsbire } \\
\text { Vermont } \\
\text { Massachusetts. } \\
\text { Rhode Island } \\
\text { Connecticut. } \\
\text { MIDDLE ATLANTIC: }\end{array}$ & $\begin{array}{l}93.3 \\
83.3 \\
77.3 \\
93.7 \\
88.9 \\
\mathbf{7 5 . 8}\end{array}$ & $\begin{array}{r}100.0 \\
85.7 \\
75.0 \\
86.1 \\
68.4 \\
67.7\end{array}$ & $\begin{array}{l}85.7 \\
78.6 \\
85.0 \\
86.4 \\
70.0 \\
67.6\end{array}$ & $\begin{array}{r}6.7 \\
16.7 \\
18.2 \\
4.8 \\
15.2\end{array}$ & $\begin{array}{r}7.1 \\
14.3 \\
6.8 \\
26.3 \\
24.6\end{array}$ & $\begin{array}{r}10.7 \\
14.3 \\
10.0 \\
9.7 \\
30.0 \\
21.0\end{array}$ \\
\hline $\begin{array}{l}\text { New York } \\
\text { New Jersey } \\
\text { Pennsylvanla.... } \\
\text { EAst NorTh CENTRA: }\end{array}$ & $\begin{array}{l}75.7 \\
62.4 \\
63.5\end{array}$ & $\begin{array}{l}62.0 \\
53.5 \\
57.9\end{array}$ & $\begin{array}{l}65.4 \\
55.5 \\
62.2\end{array}$ & $\begin{array}{l}22.3 \\
33.9 \\
32.6\end{array}$ & $\begin{array}{l}29.0 \\
42.9 \\
32.2\end{array}$ & $\begin{array}{l}30.5 \\
38.8 \\
32.0\end{array}$ \\
\hline 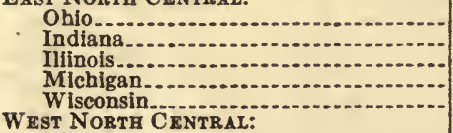 & $\begin{array}{l}63.5 \\
59.7 \\
51.4 \\
78.9 \\
74.5\end{array}$ & $\begin{array}{l}65.2 \\
53.5 \\
59.8 \\
73.4 \\
87.2\end{array}$ & $\begin{array}{l}67.3 \\
58.1 \\
55.3 \\
78.4 \\
81.3\end{array}$ & $\begin{array}{l}35.6 \\
39.9 \\
47.9 \\
19.9 \\
25.5\end{array}$ & $\begin{array}{l}32.6 \\
44.0 \\
39.2 \\
25.3 \\
12.8\end{array}$ & $\begin{array}{l}31.3 \\
40.0 \\
43.4 \\
20.2 \\
16.7\end{array}$ \\
\hline $\begin{array}{l}\text { Minnesota } \\
\text { Missourí } \\
\text { North Dakots } \\
\text { South Dakota. } \\
\text { Nebraska... } \\
\text { Kansas. }\end{array}$ & $\begin{array}{l}70.4 \\
56.8 \\
19.9 \\
50.0 \\
65.0 \\
12.1 \\
57.4\end{array}$ & $\begin{array}{l}72.7 \\
67.9 \\
58.2 \\
42.3 \\
70.2 \\
49.2 \\
62.5\end{array}$ & $\begin{array}{l}55.2 \\
65.2 \\
57.5 \\
81.8 \\
85.1 \\
78.1 \\
63.8\end{array}$ & $\begin{array}{l}29.6 \\
43.2 \\
79.8 \\
50.0 \\
32.5 \\
57.9 \\
41.6\end{array}$ & $\begin{array}{l}27.3 \\
31.2 \\
40.1 \\
50.0 \\
27.7 \\
44.4 \\
36.0\end{array}$ & $\begin{array}{l}41.4 \\
33.7 \\
41.3 \\
18.2 \\
14.9 \\
21.9 \\
34.9\end{array}$ \\
\hline $\begin{array}{l}\text { Melaware } \\
\text { Maryland } \\
\text { District of Columbia } \\
\text { Virginia } \\
\text { West Virginia } \\
\text { North Caroling } \\
\text { South Carolina } \\
\text { Georgia } \\
\text { Florida } \\
\text { EAsT Soutr CENTRAL: }\end{array}$ & $\begin{array}{l}46.2 \\
55.8 \\
72.7 \\
61.6 \\
75.9 \\
25.4 \\
20.7 \\
12.8 \\
50.5\end{array}$ & $\begin{array}{l}40.7 \\
57.2 \\
45.0 \\
64.8 \\
80.0 \\
29.0 \\
20.9 \\
12.3 \\
48.8\end{array}$ & $\begin{array}{l}44.0 \\
62.0 \\
66.7 \\
67.0 \\
78.8 \\
32.1 \\
21.0 \\
12.8 \\
49.6\end{array}$ & $\begin{array}{l}51.4 \\
41.9 \\
18.2 \\
38.2 \\
22.7 \\
74.5 \\
79.3 \\
87.2 \\
48.7\end{array}$ & $\begin{array}{l}57.8 \\
40.4 \\
50.0 \\
34.8 \\
18.5 \\
70.9 \\
79.0 \\
87.5 \\
50.4\end{array}$ & $\begin{array}{l}54.2 \\
36.6 \\
25.0 \\
32.7 \\
20.2 \\
67.8 \\
78.8 \\
87.1 \\
49.7\end{array}$ \\
\hline 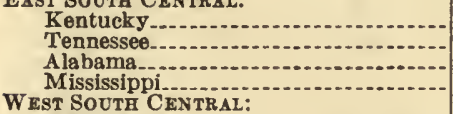 & $\begin{array}{l}45.9 \\
22.3 \\
17.0 \\
12.4\end{array}$ & $\begin{array}{l}42.1 \\
25.8 \\
18.1 \\
14.4\end{array}$ & $\begin{array}{l}50.5 \\
27.9 \\
15.4 \\
15.2\end{array}$ & $\begin{array}{l}54.0 \\
77.6 \\
83.0 \\
87.6\end{array}$ & $\begin{array}{l}57.6 \\
74.1 \\
81.8 \\
85.5\end{array}$ & $\begin{array}{l}49.1 \\
71.9 \\
84.5 \\
84.8\end{array}$ \\
\hline 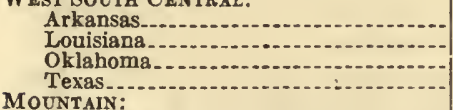 & $\begin{array}{l}14.4 \\
14.2 \\
22.8 \\
23.9\end{array}$ & $\begin{array}{l}21.3 \\
17.7 \\
37.0 \\
29.9\end{array}$ & $\begin{array}{l}23.1 \\
19.5 \\
36.5 \\
30.3\end{array}$ & $\begin{array}{l}85.6 \\
85.7 \\
77.1 \\
76.0\end{array}$ & $\begin{array}{l}78.6 \\
82.2 \\
62.4 \\
69.9\end{array}$ & $\begin{array}{l}76.9 \\
80.4 \\
63.4 \\
69.5\end{array}$ \\
\hline $\begin{array}{l}\text { MoUNTAIN: } \\
\text { Montana } \\
\text { Idaho }\end{array}$ & 71.4 & 83.9 & 75.9 & 28.6 & 12.9 & 17.2 \\
\hline Idaho Woming & $\begin{array}{l}43.8 \\
66.7\end{array}$ & $\begin{array}{r}69.6 \\
100.0\end{array}$ & $\begin{array}{r}100.0 \\
89.5\end{array}$ & $\begin{array}{l}43.8 \\
33.3\end{array}$ & & $5 . \overline{3}$ \\
\hline Colorado do & 69.2 & 77.7 & 71.6 & 29.5 & 18.9 & 27.2 \\
\hline $\begin{array}{l}\text { New Mexico } \\
\text { Arizona }\end{array}$ & $\begin{array}{l}64.6 \\
46.0\end{array}$ & $\begin{array}{l}75.0 \\
59.4\end{array}$ & $\begin{array}{l}85.4 \\
83.3\end{array}$ & $\begin{array}{l}35.4 \\
50.6\end{array}$ & $\begin{array}{l}25.0 \\
31.3\end{array}$ & $\begin{array}{r}6.3 \\
16.7\end{array}$ \\
\hline Utah. & 80.0 & 31.1 & 100.0 & 20.0 & 67.2 & $\begin{array}{r}10.8 \\
-. . .\end{array}$ \\
\hline $\begin{array}{l}\text { Nevada } \\
\text { Pacific: }\end{array}$ & 66.7 & 60.0 & 66.7 & 33.3 & 40.0 & 16.7 \\
\hline $\begin{array}{l}\text { Washington } \\
\text { Oregon } \\
\text { California }\end{array}$ & $\begin{array}{l}83.6 \\
88.9 \\
49.5\end{array}$ & $\begin{array}{l}82.3 \\
73.3 \\
63.1\end{array}$ & $\begin{array}{l}83.1 \\
81.5 \\
78.6\end{array}$ & $\begin{array}{l}13.7 \\
11.1 \\
46.2\end{array}$ & $\begin{array}{l}17.7 \\
13.3 \\
32.4\end{array}$ & $\begin{array}{l}14.3 \\
14.8 \\
16.4\end{array}$ \\
\hline
\end{tabular}

Loss of owned land.- In Table 26 the land (acres) in farms operated by Negro owners, tenants, and managers in 1930 and 1920 is apportioned by sections with the increase or decrease, and the per cent distribution by tenure of all land. The land operated by owners decreased from $13,948,512$ acres in 1920 to $11,198,893$ in 1930 which represents a loss during the 10 years of $2,749,619$ acres, or an area $(4,296$ square miles) more than twice the size of Delaware, and as shown by 
Table 36, Negro farm owners in all but eight States contributed to this economic loss. Possibly the most striking fact is the loss of 19.7 per cent in the acreage of owned farms, as compared with a decrease of only 3.4 per cent among tenant operators. The per cent distribution indicates that 29.8 per cent of the land in 1930 and 33.7 per cent in 1920 was operated by owners, although only 20.5 per cent of the farmers were owners in 1930, and but 23.6 per cent in 1920. (See Table 25.) Only in the West was 50 per cent or more of the acreage operated by owners.

Table 26. - Number of Acres in Farms Operated by Negroes, With PerCentages, By Tendre, By Sections: 1930 and 1920

[A minus sign ( $(-)$ denotes decrease]

\begin{tabular}{|c|c|c|c|c|c|c|}
\hline \multirow{3}{*}{ TENURE } & \multicolumn{6}{|c|}{ ACRES IN FARMS } \\
\hline & \multirow{2}{*}{1930} & \multirow{2}{*}{1920} & \multicolumn{2}{|c|}{ Increase, $1920-1930$} & \multicolumn{2}{|c|}{$\begin{array}{l}\text { Per cent distri- } \\
\text { bution }\end{array}$} \\
\hline & & & Number & Per cent & 1930 & 1920 \\
\hline 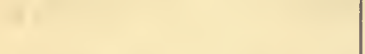 & \multicolumn{6}{|c|}{ UNITED STATES } \\
\hline Total............. & $37,597,132$ & $41,482,182$ & $-3,835,050$ & -9.3 & 100.0 & 100.0 \\
\hline \multirow[t]{2}{*}{$\begin{array}{l}\text { Owners..... } \\
\text { Tenants_. } \\
\text { Managers.... }\end{array}$} & $\begin{array}{r}11,198,893 \\
26,149,167 \\
249,072\end{array}$ & $\begin{array}{r}13,948,512 \\
27,077,582 \\
406,088\end{array}$ & $\begin{array}{r}-2,749,619 \\
-928,415 \\
-157,016\end{array}$ & $\begin{array}{r}-19.7 \\
-3.4 \\
-38.7\end{array}$ & $\begin{array}{r}29.8 \\
69.6 \\
0.7\end{array}$ & $\begin{array}{r}33.7 \\
65.4 \\
1.0\end{array}$ \\
\hline & \multicolumn{6}{|c|}{ THE SOUTH } \\
\hline Total & $38,758,484$ & $40,544,241$ & $-3,785,757$ & -9.3 & 100.0 & 100.0 \\
\hline \multirow[t]{2}{*}{$\begin{array}{l}\text { Owners } \\
\text { Tenants......... } \\
\text { Managers... }\end{array}$} & $\begin{array}{r}10,785,312 \\
25,743,234 \\
229,938\end{array}$ & $\begin{array}{r}13,434,106 \\
26,754,386 \\
355,749\end{array}$ & $\begin{array}{r}-2,648,794 \\
-1,011,152 \\
-125,811\end{array}$ & $\begin{array}{r}-19.7 \\
-3.8 \\
-35.4\end{array}$ & $\begin{array}{r}29.3 \\
70.0 \\
0.6\end{array}$ & $\begin{array}{r}33.1 \\
66.0 \\
0.9\end{array}$ \\
\hline & \multicolumn{6}{|c|}{ THE NORTH } \\
\hline Total... & 720,872 & 767,953 & $-47,081$ & -8.1 & 100.0 & 100.0 \\
\hline \multirow[t]{2}{*}{$\begin{array}{l}\text { Owners. } \\
\text { Tenants...... } \\
\text { Managers. }\end{array}$} & $\begin{array}{r}332,520 \\
373,214 \\
15,138\end{array}$ & $\begin{array}{r}435,075 \\
294,543 \\
38,335\end{array}$ & $\begin{array}{r}-102,555 \\
78,671 \\
-23,197\end{array}$ & $\begin{array}{r}-23.6 \\
26.7 \\
-60.5\end{array}$ & $\begin{array}{r}46.1 \\
51.8 \\
2.1\end{array}$ & $\begin{array}{r}56.7 \\
38.4 \\
5.0\end{array}$ \\
\hline & \multicolumn{6}{|c|}{ THE WEST } \\
\hline Total.. & 117,776 & 119,988 & $-2,212$ & -1.8 & 100.0 & 100.0 \\
\hline $\begin{array}{l}\text { Owners. } \\
\text { Tenants, } \\
\text { Managers }\end{array}$ & $\begin{array}{r}81,061 \\
32,719 \\
3,996\end{array}$ & $\begin{array}{l}79,331 \\
28,653 \\
12,004\end{array}$ & $\begin{array}{r}1,730 \\
4,066 \\
-8,008\end{array}$ & $\begin{array}{r}2.2 \\
14.2 \\
-66.7\end{array}$ & $\begin{array}{r}68.8 \\
27.8 \\
3.4\end{array}$ & $\begin{array}{l}66.1 \\
23.9 \\
10.0\end{array}$ \\
\hline
\end{tabular}

Average values.-The general decline in the values of Negro-operated farms from the high levels of 1920 is plainly reflected in the greatly reduced average values shown in Table 27. The average value per farm of land and buildings decreased $\$ 850$, or 34.9 per cent, and the average value of land and buildings per acre of Negro-operated farms dropped from $\$ 54.49$ in 1920 to $\$ 37.32$ in 1930 , a shrinkage of $\$ 17.17$ per acre during the 10 years. The downward trend resulted in a decrease for owners of $\$ 687$, or 27.1 per cent in the average value per farm of land and buildings, and a loss of $\$ 9.87$, or 24.8 per cent in the average value per acre of land and buildings. Both amounts and percentage decreases per farm-and acre were higher for tenants in the United States as a whole. 
In the South, Negro owners sustained a loss of $\$ 676$ in the average value per farm of land and buildings as compared with one of $\$ 956$ in the North and $\$ 1,253$ in the West. The average value per acre of land and buildings of Negro owners in the South decreased $\$ 9.75$; in the North, $\$ 12.28$; and in the West, $\$ 11.21$, while the per cent average value reductions for owners by sections were 25.1 for the South; 18.8 for the North; and 25.4 for the West.

Table 27.-Average Value of Land and Buildings of Farms Operated by Negroes, Per Farm and Per Acre, by Tenure, by Sections and Southern Drvisions: 1930 and 1920

[A minus sign (-) denotes decrease]

\begin{tabular}{|c|c|c|c|c|c|c|c|c|}
\hline \multirow{4}{*}{ SECTION, DIVISION, AND } & \multicolumn{8}{|c|}{ AVERAGE VALUE OF LAND AND BUILDINGS } \\
\hline & \multicolumn{4}{|c|}{ Per farm } & \multicolumn{4}{|c|}{ Per acre } \\
\hline & \multirow{2}{*}{1930} & \multirow{2}{*}{1920} & \multicolumn{2}{|c|}{ Increase, $1920-1930$} & \multirow{2}{*}{1930} & \multirow{2}{*}{1920} & \multicolumn{2}{|c|}{ Increase, $1920-1930$} \\
\hline & & & Amount & Per cent & & & Amount & Per cent \\
\hline United States........ & $\$ 1,589$ & $\$ 2,489$ & $-\$ 850$ & -34.9 & $\$ 37.32$ & $\$ 54.48$ & $-\$ 17.17$ & -31.5 \\
\hline $\begin{array}{l}\text { Owners.... } \\
\text { Tenants... } \\
\text { Managers }\end{array}$ & $\begin{array}{r}1,848 \\
1,503 \\
16,083 \\
\end{array}$ & $\begin{array}{r}2,535 \\
2,378 \\
13,411 \\
\end{array}$ & $\begin{array}{l}-687 \\
-875 \\
2,672 \\
\end{array}$ & $\begin{array}{r}-27.1 \\
-36.8 \\
19.9 \\
\end{array}$ & $\begin{array}{l}29.86 \\
40.29 \\
59.60 \\
\end{array}$ & $\begin{array}{l}39.73 \\
61.91 \\
66 \quad 91 \\
\end{array}$ & $\begin{array}{r}-9.87 \\
-21.62 \\
-7.31 \\
\end{array}$ & $\begin{array}{l}-24.8 \\
-34.9 \\
-10.9 \\
\end{array}$ \\
\hline $\begin{array}{l}\text { The South } \\
\text { Owners } \\
\text { Tenants............ } \\
\text { Managers. }\end{array}$ & $\begin{array}{r}1,556 \\
1,783 \\
1,482 \\
15,789 \\
\end{array}$ & $\begin{array}{r}2,393 \\
2,459 \\
2,349 \\
12,155 \\
\end{array}$ & $\begin{array}{l}-837 \\
-676 \\
-867 \\
3,634 \\
\end{array}$ & $\begin{array}{r}-35.0 \\
-27.5 \\
-36.9 \\
29.9 \\
\end{array}$ & $\begin{array}{l}36.87 \\
29.12 \\
39.95 \\
55.27\end{array}$ & $\begin{array}{l}54.04 \\
38.87 \\
61.58 \\
60.10 \\
\end{array}$ & $\begin{array}{r}-17.17 \\
-9.75 \\
-21.63 \\
-4.83 \\
\end{array}$ & $\begin{array}{l}-31.8 \\
-25.1 \\
-35.1 \\
-8.0 \\
\end{array}$ \\
\hline 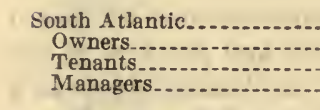 & $\begin{array}{r}1,637 \\
1,703 \\
1,585 \\
14,250\end{array}$ & $\begin{array}{r}2,568 \\
2,323 \\
2,626 \\
11,662\end{array}$ & $\begin{array}{r}-931 \\
-620 \\
-1,041 \\
2,588\end{array}$ & $\begin{array}{r}-36.3 \\
-26.7 \\
-39.6 \\
22.2\end{array}$ & $\begin{array}{l}\text { 33. } 29 \\
32.20 \\
33.43 \\
62.30\end{array}$ & $\begin{array}{l}54.08 \\
43.24 \\
58.57 \\
76.39\end{array}$ & $\begin{array}{l}-20.79 \\
-11.04 \\
-25.14 \\
-14.09\end{array}$ & $\begin{array}{l}-38.4 \\
-25.5 \\
-42.9 \\
-18.4\end{array}$ \\
\hline $\begin{array}{l}\text { East South Central } \\
\text { Owners } \\
\text { Tenants } \\
\text { Managers................ }\end{array}$ & $\begin{array}{r}1,330 \\
1,634 \\
1,263 \\
22,237\end{array}$ & $\begin{array}{r}2,104 \\
2,296 \\
2,046 \\
11,453\end{array}$ & $\begin{array}{r}-774 \\
-662 \\
-783 \\
10,784\end{array}$ & $\begin{array}{r}-36.8 \\
-28.8 \\
-38.3 \\
94.2\end{array}$ & $\begin{array}{l}35.79 \\
23.45 \\
40.83 \\
62.27\end{array}$ & $\begin{array}{l}53.35 \\
32.41 \\
63.52 \\
54.17\end{array}$ & $\begin{array}{r}-17.56 \\
-8.96 \\
-22.69 \\
8.10\end{array}$ & $\begin{array}{r}-32.9 \\
-27.6 \\
-35.7 \\
15.0\end{array}$ \\
\hline $\begin{array}{l}\text { West South Central. } \\
\text { Owners } \\
\text { Tenants........... } \\
\text { Managers... }\end{array}$ & $\begin{array}{r}1,746 \\
2,087 \\
1,659 \\
14,890\end{array}$ & $\begin{array}{r}2,490 \\
2,876 \\
2,339 \\
14,059\end{array}$ & $\begin{array}{r}-744 \\
-789 \\
-680 \\
831\end{array}$ & $\begin{array}{r}-29.9 \\
-27.4 \\
-29.1 \\
5.9\end{array}$ & $\begin{array}{l}43.17 \\
31.41 \\
48.22 \\
39.52\end{array}$ & $\begin{array}{l}54.77 \\
39.22 \\
65.14 \\
45.02\end{array}$ & $\begin{array}{r}-11.60 \\
-7.81 \\
-16.92 \\
-5.50\end{array}$ & $\begin{array}{l}-21.2 \\
-19.9 \\
-26.0 \\
-12.2\end{array}$ \\
\hline 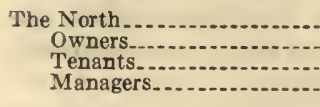 & $\begin{array}{r}3,753 \\
3,998 \\
3,389 \\
17,997\end{array}$ & $\begin{array}{r}6,379 \\
4,954 \\
7,748 \\
21,042\end{array}$ & $\begin{array}{r}-2,626 \\
-956 \\
-4,359 \\
-3,045\end{array}$ & $\begin{array}{l}-41.2 \\
-19.3 \\
-56.3 \\
-14.5\end{array}$ & $\begin{array}{r}57.80 \\
53.18 \\
59.82 \\
109.38\end{array}$ & $\begin{array}{r}77.91 \\
65.46 \\
89.15 \\
132.84\end{array}$ & $\begin{array}{l}-20.11 \\
-12.28 \\
-29.33 \\
-23.46\end{array}$ & $\begin{array}{l}-25.8 \\
-18.8 \\
-32.9 \\
-17.7\end{array}$ \\
\hline 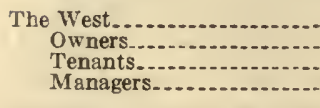 & $\begin{array}{r}7.526 \\
5,771 \\
9,164 \\
18,431\end{array}$ & $\begin{array}{r}9,287 \\
7,024 \\
12,428 \\
27,972\end{array}$ & $\begin{array}{l}-1,761 \\
-1,253 \\
-3,264 \\
-9,541\end{array}$ & $\begin{array}{l}-19.0 \\
-17.8 \\
-26.3 \\
-34.1\end{array}$ & $\begin{array}{r}51.76 \\
32.89 \\
90.18 \\
119.92\end{array}$ & $\begin{array}{l}56.73 \\
44.10 \\
91.08 \\
58.26\end{array}$ & $\begin{array}{r}-4.97 \\
-11.21 \\
-0.90 \\
61.66\end{array}$ & $\begin{array}{r}-8.8 \\
-25.4 \\
-1.0 \\
105.8\end{array}$ \\
\hline
\end{tabular}

Land values.-For the country as a whole, the value of land in farms operated by Negroes in 1930 was $\$ 1,062,536,439$, as shown in Table 28 . The per cent distribution of this aggregate value by sections indicates that 96.6 per cent was in the South; 2.9 per cent in the North, and one-half of 1 per cent in the West.

When distributed according to the tenure of operators, however, a slight difference appears for both owners and tenants, and also for managers. Owned farm land in the South had a reported value of $\$ 214,907,952$, or 94 per cent of the total value of all farm land operated by Negro owners. In the North their owned land had a value of $\$ 11,611,190$, or 5.1 per cent of the total, and in the West the value amounted to $\$ 2,190,558$, or 1 per cent of the total for the United States. 
Table 28.-Value of Land in Farms Operated by Negroes, by Tendre, By Sections and Drvisions, 1930

\begin{tabular}{|c|c|c|c|c|}
\hline.+ & \multicolumn{4}{|c|}{ VALUE OF LAND ALONE } \\
\hline 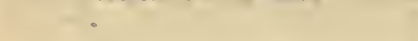 & Total & Owners & Tenants & Managers \\
\hline Onited States. & $81,082,536,439$ & $8228,709,700$ & $8823,005,516$ & $\$ 10,821,223$ \\
\hline The South... & $1,026,877,643$ & $214,907,952$ & $802,581,553$ & $9,388,138$ \\
\hline $\begin{array}{l}\text { South Atlantic } \\
\text { East South Central } \\
\text { West South Central. }\end{array}$ & $\begin{array}{l}342,118,722 \\
323,130,648 \\
361,628,273\end{array}$ & $\begin{array}{l}85,227,015 \\
57,360,605 \\
72,320,332\end{array}$ & $\begin{array}{l}252,300,365 \\
263,328,563 \\
286,952,625\end{array}$ & $\begin{array}{l}4,591,342 \\
2,441,430 \\
2,355,316\end{array}$ \\
\hline The North........ & $30,366,748$ & $11,611,190$ & $17,726,373$ & $1,029,185$ \\
\hline $\begin{array}{l}\text { New England } \\
\text { Middle Atlantic. } \\
\text { East North Central } \\
\text { West North Central }\end{array}$ & $\begin{array}{r}406,290 \\
2,687,260 \\
9,130,656 \\
18,142,542\end{array}$ & $\begin{array}{r}302,565 \\
1,095,865 \\
4,265,786 \\
5,946,974\end{array}$ & $\begin{array}{r}31,725 \\
1,282,195 \\
4,602,325 \\
11,810,128\end{array}$ & $\begin{array}{r}72,000 \\
309,200 \\
262,545 \\
385,440\end{array}$ \\
\hline The West... & $5,292,048$ & $2,190,558$ & $2,697,590$ & 403,900 \\
\hline $\begin{array}{l}\text { Mountain } \\
\text { Pacific }\end{array}$ & $\begin{array}{l}1,792,685 \\
3,499,363\end{array}$ & $\begin{array}{r}802,065 \\
1,388,493\end{array}$ & $\begin{array}{r}919,620 \\
1,777,970\end{array}$ & $\begin{array}{r}71,000 \\
332,900\end{array}$ \\
\hline 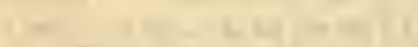 & \multicolumn{4}{|c|}{ PER CENT DISTRIBUTION } \\
\hline Onited States.... & 100.0 & 100.0 & 100.0 & 100.0 \\
\hline $\begin{array}{l}\text { The South } \\
\text { The North } \\
\text { The West }\end{array}$ & $\begin{array}{r}96.6 \\
2.9 \\
0.5\end{array}$ & $\begin{array}{r}94.0 \\
5.1 \\
1.0\end{array}$ & $\begin{array}{r}97.5 \\
2.2 \\
0.3\end{array}$ & $\begin{array}{r}86.8 \\
9.5 \\
3.7\end{array}$ \\
\hline
\end{tabular}

Owner and tenant comparisons.- The average size of farms operated by Negro owners and tenants in 1930 and the average value per farm and per acre of the land (alone) operated by them is shown in Table 29. For the United States as a whole; in each section and in all of the Southern States except Delaware, Maryland, Virginia, and West Virginia the average size of farms operated by Negro owners was larger than for tenants, but only in Delaware, Maryland, District of Columbia, and Florida was the average value of land per acre greater for owners than for tenants. Excepting the negligible District of Columbia, the State of - Maryland reported the highest average value per acre for owners, while Georgia reported the lowest. The highest average value per acre for Negro tenant operators was reported by Arkansas and the lowest by Georgia which, as previously stated, reported the lowest average value per acre for owners. 
Table 29.-Average Size and Average Valde of Farms and Farm Acreage Operated by Negro Owners and Tenants by Sections, Southery DryiSIONS AND STATES, 1930

\begin{tabular}{|c|c|c|c|c|c|c|}
\hline \multirow{4}{*}{ SECTION AND STATE } & \multicolumn{6}{|c|}{ FARUS OPERATED BY NEGROES } \\
\hline & \multicolumn{2}{|c|}{ A verage size (acres) } & \multicolumn{4}{|c|}{ A verage value (land alone) } \\
\hline & \multirow{2}{*}{ Owners } & \multirow{2}{*}{ Tenants } & \multicolumn{2}{|c|}{ Per farm } & \multicolumn{2}{|c|}{ Per acre } \\
\hline & & & Owners & Tenants & Owners & Tenants \\
\hline United States.... & 61.9 & 37.3 & 81,263 & 81,174 & 820.42 & $\$ 31.47$ \\
\hline The South............... & 61.2 & 37.1 & 1,220 & 1,156 & 19.93 & 31.18 \\
\hline $\begin{array}{l}\text { South Atlantic } \\
\text { East South Central } \\
\text { West South Central }\end{array}$ & $\begin{array}{l}52.9 \\
69.7 \\
66.4\end{array}$ & $\begin{array}{l}47.4 \\
30.9 \\
34.4\end{array}$ & $\begin{array}{l}1,070 \\
1,136 \\
1,573\end{array}$ & $\begin{array}{r}1,169 \\
975 \\
1,378\end{array}$ & $\begin{array}{l}20.22 \\
16.31 \\
23.68\end{array}$ & $\begin{array}{r}24.67 \\
31.53 \\
40.05\end{array}$ \\
\hline $\begin{array}{l}\text { The North } \\
\text { The West................... }\end{array}$ & $\begin{array}{r}75.2 \\
175.5 \\
\end{array}$ & $\begin{array}{r}56.7 \\
101.6 \\
\end{array}$ & $\begin{array}{l}2,625 \\
4,741 \\
\end{array}$ & $\begin{array}{l}2,691 \\
8,378 \\
\end{array}$ & $\begin{array}{l}34.92 \\
27.02 \\
\end{array}$ & $\begin{array}{l}47.50 \\
82.45 \\
\end{array}$ \\
\hline THE SOUTH & & & & & & \\
\hline $\begin{array}{l}\text { SouTH ATLANTIC: } \\
\text { Delaware } \\
\text { Maryland } \\
\text { District of Columbia. } \\
\text { Virginia_. } \\
\text { West Virginia... } \\
\text { North Carolina } \\
\text { South Carolins } \\
\text { Georgia } \\
\text { Florida } \\
\text { EAST SoutH CENTRAL: }\end{array}$ & $\begin{array}{r}36.9 \\
36.6 \\
3.5 \\
43.4 \\
49.7 \\
49.7 \\
49.3 \\
79.7 \\
50.6\end{array}$ & $\begin{array}{r}90.7 \\
97.8 \\
3.5 \\
55.3 \\
77.2 \\
42.2 \\
33.5 \\
55.5 \\
41.7\end{array}$ & $\begin{array}{r}1,031 \\
1,224 \\
3,466 \\
948 \\
1,380 \\
1,300 \\
945 \\
1,066 \\
1,077\end{array}$ & $\begin{array}{r}2,360 \\
3,225 \\
1,500 \\
1,273 \\
2,451 \\
1,575 \\
1,014 \\
931 \\
848\end{array}$ & $\begin{array}{r}27.91 \\
33.41 \\
990.18 \\
19.60 \\
27.79 \\
26.15 \\
19.19 \\
13.38 \\
21.29\end{array}$ & $\begin{array}{r}26.02 \\
32.97 \\
428.57 \\
22.99 \\
31.74 \\
37.34 \\
26.33 \\
16.77 \\
20.32\end{array}$ \\
\hline 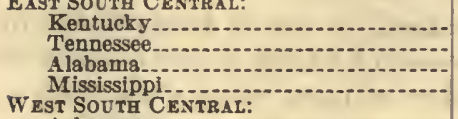 & $\begin{array}{l}43.9 \\
53.5 \\
74.7 \\
76.5\end{array}$ & $\begin{array}{l}31.8 \\
34.2 \\
37.9 \\
26.9\end{array}$ & $\begin{array}{l}1,136 \\
1,248 \\
1,092 \\
1,129\end{array}$ & $\begin{array}{r}1,286 \\
1,186 \\
764 \\
1,033\end{array}$ & $\begin{array}{l}25.90 \\
23.31 \\
14.62 \\
14.76\end{array}$ & $\begin{array}{l}40.48 \\
34.70 \\
20.14 \\
38.33\end{array}$ \\
\hline 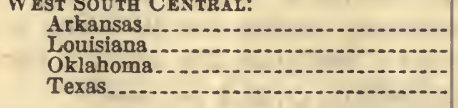 & $\begin{array}{l}61.5 \\
57.3 \\
82.2 \\
71.1\end{array}$ & $\begin{array}{l}26.1 \\
26.8 \\
65.9 \\
44.9\end{array}$ & $\begin{array}{l}1,417 \\
1,370 \\
2,275 \\
1,646\end{array}$ & $\begin{array}{l}1,143 \\
1,131 \\
2,068 \\
1,739\end{array}$ & $\begin{array}{l}23.03 \\
23.89 \\
27.68 \\
23.13\end{array}$ & $\begin{array}{l}43.87 \\
42.24 \\
31.38 \\
38.75\end{array}$ \\
\hline
\end{tabular}

Value of all buildings. - The buildings on farms operated by Negroes had a value of $\$ 340,409,360$, as reported in Table 30 . The South reported values to the amount of $\$ 328,304,024$, or 96.4 per cent of the total, the North reported $\$ 11,301,474$, or 3.3 per cent, and the West a value less than $\$ 1,000,000$, or $\$ 803,862$, which was less than one-half of 1 per cent of the total value for the United States.

As in the preceding table substantial differences appear in the per cent distribution of values by tenure of operators. In the South, farm buildings owned by Negroes were valued at $\$ 99,192,480$, or 93.8 per cent of the total, $\$ 105,741,696$, for the United States; in the North at \$6,073,789, or 5.7 per cent; and in the West at $\$ 475,427$, an amount equal to one-half of 1 per cent of the aggregate value. With 29,208 more owned farms in the South Atlantic division than in the East South Central (see Table 35 ) the value of owned farm buildings in the South Atlantic division exceeds by $\$ 25,404,681$ the value in the East South Central. The higher average value of land and buildings per owned farm and per acre in the South Atlantic division is shown in Table 27. 
Table 30.-Value of All Buildings on Farms Operated by Negroes, by Tenure, by Sections and Divisions, 1930

\begin{tabular}{|c|c|c|c|c|}
\hline-1 & \multicolumn{4}{|c|}{ VALUE OF ALL BUILDINGS } \\
\hline SECTION AND DIVISION & Total & Owners & Tenants & Managers \\
\hline Onited States... & $8940,409, \$ 60$ & $8105,741,696$ & $8250,644,120$ & $84,028,544$ \\
\hline The South..... & $328,304,024$ & $99,192,480$ & $225,789,875$ & $3,321,669$ \\
\hline $\begin{array}{l}\text { South Atlantic } \\
\text { East South Central } \\
\text { West South Central }\end{array}$ & $\begin{array}{r}142,325,221 \\
103,398,196 \\
82,580,607\end{array}$ & $\begin{array}{l}50,497,142 \\
25,092,461 \\
23,602,877\end{array}$ & $\begin{array}{l}89,622,060 \\
77,634,070 \\
58,533,745\end{array}$ & $\begin{array}{r}2,206,019 \\
671,665 \\
443,985\end{array}$ \\
\hline The North.............. & $11,301,474$ & $6,073,789$ & $4,601,110$ & 626,575 \\
\hline $\begin{array}{l}\text { New England } \\
\text { Middle Atlantic } \\
\text { East North Central } \\
\text { West North Centra] }\end{array}$ & $\begin{array}{r}503,105 \\
2,452,995 \\
4,174,095 \\
4,171,279\end{array}$ & $\begin{array}{r}348,760 \\
1,326,810 \\
2,530,750 \\
1,867,469\end{array}$ & $\begin{array}{r}35,345 \\
883,685 \\
1,490,320 \\
2,191,760\end{array}$ & $\begin{array}{l}119,000 \\
242,505 \\
153,020 \\
112,050\end{array}$ \\
\hline The West....... & 803,862 & 475,427 & 253,135 & 75,300 \\
\hline Mountain & $\begin{array}{l}244,825 \\
559,037\end{array}$ & $\begin{array}{l}141,620 \\
333,807\end{array}$ & $\begin{array}{r}93,205 \\
159,930\end{array}$ & $\begin{array}{l}10,000 \\
65,300\end{array}$ \\
\hline$x^{2}$ & & PER CENT DIS & IBUTION & \\
\hline Dnited States........ & 100.0 & 100.0 & 100.0 & 100.0 \\
\hline $\begin{array}{l}\text { The South } \\
\text { The North } \\
\text { The West. }\end{array}$ & $\begin{array}{r}96.4 \\
3.3 \\
0.2\end{array}$ & $\begin{array}{r}93.8 \\
5.7 \\
0.4\end{array}$ & $\begin{array}{r}97.9 \\
2.0 \\
0.1\end{array}$ & $\begin{array}{r}82.6 \\
15.6 \\
1.9\end{array}$ \\
\hline
\end{tabular}

Shrinkage of farm values, by tenure of operators.-A loss of $\$ 854,699,526$ in the value of land and buildings, due to a decrease of $42,85 \mathrm{~s}$ in the number of Negro farmers, and also to the widespread decline of farm values since 1920, is shown in Table 31. For owners there was a decrease, during the 10 years, of $\$ 219,706,607$, or 39.6 per cent. Tenants reported a $\$ 622,666,228$, or 37.1 per cent reduction, and managers a shrinkage of $\$ 12,326,691$, or 45.4 per cent.

The reports of Negro owners in the South showed a loss of $\$ 208,077,705$, or 39.8 per cent; of those in the North, $\$ 10,796,782$, or 37.9 per cent, and of those in the West, $\$ 832,120$, or 23.8 per cent. The great decrease, between 1920 and 1930 , in the value of farm land owned by Negroes results from two factors-a decrease in the acreage owned, as indicated in Table 26, and the decrease in the value of the acreage they still own. (See Table 27.) These figures show a loss of 2,749,619 acres formerly owned by Negro farm operators, and a decrease of $\$ 687$ per farm, or nearly $\$ 10$ per acre in the average value of owned farm land and buildings. The only sectional increase reported in the value of land and buildings of Negro farmers was for tenants in the West where there was an increase of \$340,911, or 13.1 per cent. 
Table 31.-Value of land and Buildings for farms Operated by Negroes, by Tendre, By Sections: 1930 aNd 1920

[A minus sign (-) denotes decrease]

\begin{tabular}{|c|c|c|c|c|c|c|}
\hline \multirow{3}{*}{ 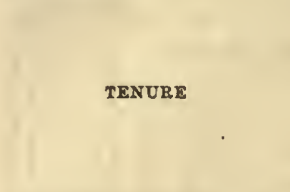 } & \multicolumn{6}{|c|}{ VALUE OF LAND AND BUILDINGS } \\
\hline & \multirow{2}{*}{1930} & \multirow{2}{*}{1920} & \multicolumn{2}{|c|}{ Increase, 1920-1930 } & \multicolumn{2}{|c|}{$\begin{array}{l}\text { Per cent dis- } \\
\text { tribution }\end{array}$} \\
\hline & & & Amount & Per cent & 1030 & 1920 \\
\hline 1 & \multicolumn{6}{|c|}{ UNITED STATES } \\
\hline Total. & $81,402,945,798$ & $\$ 2,257,645,325$ & $-8854,689,526$ & -97.8 & 100.0 & 100.0 \\
\hline \multirow[t]{2}{*}{$\begin{array}{l}\text { Owners. } \\
\text { Tenants... } \\
\text { Managers...... }\end{array}$} & $\begin{array}{r}334,451,396 \\
1,053,649,636 \\
14,844,767\end{array}$ & $\begin{array}{r}554,158,003 \\
1,676,315,864 \\
27,171,458\end{array}$ & $\begin{array}{r}-219,706,607 \\
-622,666,228 \\
-12,326,691\end{array}$ & $\begin{array}{l}-39.6 \\
-37.1 \\
-45.4\end{array}$ & $\begin{array}{r}23.8 \\
.75 .1 \\
1.1\end{array}$ & $\begin{array}{r}24.5 \\
74.3 \\
1.2\end{array}$ \\
\hline & \multicolumn{6}{|c|}{ THE SOUTH } \\
\hline Total. & $81,355,181,687$ & $82,181,005,642$ & $-8885,823,876$ & -98.1 & 100.0 & 100.0 \\
\hline \multirow[t]{2}{*}{$\begin{array}{l}\text { Owners } \\
\text { Tenants.............. } \\
\text { Managers... }\end{array}$} & $\begin{array}{r}314,100,432 \\
1,028,371,428 \\
12,709,807\end{array}$ & $\begin{array}{r}522,178,137 \\
1,647,447,607 \\
21,379,898\end{array}$ & $\begin{array}{r}-208,077,705 \\
-619,076,179 \\
-8,670,091\end{array}$ & $\begin{array}{l}-39.8 \\
-37.6 \\
-40.6\end{array}$ & $\begin{array}{r}23.2 \\
75.9 \\
0.9\end{array}$ & $\begin{array}{r}23.8 \\
75.2 \\
1.0\end{array}$ \\
\hline & \multicolumn{6}{|c|}{ THE NORTH } \\
\hline Total.. & $841,668,222$ & $859,832,464$ & $-818,164,242$ & -30.4 & 100.0 & 100.0 \\
\hline \multirow[t]{3}{*}{$\begin{array}{l}\text { Owners } \\
\text { Tenants... } \\
\text { Managers } . . .\end{array}$} & $\begin{array}{r}17,684,979 \\
22,327,483 \\
1,655,760\end{array}$ & $\begin{array}{r}28,481,761 \\
26,258,443 \\
5,092,260\end{array}$ & $\begin{array}{r}-10,796,782 \\
-3,930,960 \\
-3,436,500\end{array}$ & $\begin{array}{l}-37.9 \\
-15.0 \\
-67.5\end{array}$ & $\begin{array}{r}42.4 \\
53.6 \\
4.0\end{array}$ & $\begin{array}{r}47.6 \\
43.9 \\
8.5\end{array}$ \\
\hline & \multicolumn{4}{|c|}{ THE WEST } & & \\
\hline & $88,095,910$ & $86,807,218$ & $-8711,309$ & -10.4 & 100.0 & 100.0 \\
\hline $\begin{array}{l}\text { Owners.....-. } \\
\text { Tenants...-.. } \\
\text { Managers... }\end{array}$ & $\begin{array}{r}2,665,985 \\
2,950,725 \\
479,200\end{array}$ & $\begin{array}{r}3,498,105 \\
2,609,814 \\
699,300\end{array}$ & $\begin{array}{r}-832,120 \\
340,911 \\
-220,100\end{array}$ & $\begin{array}{r}-23.8 \\
13.1 \\
-31.5\end{array}$ & $\begin{array}{r}43.7 \\
48.4 \\
7.9\end{array}$ & $\begin{array}{l}51.4 \\
38.3 \\
10.3\end{array}$ \\
\hline
\end{tabular}

Mortgaged farms.- As indicated in Table 32, colored full owners throughout the South and in the seven selected Northern States, where 98.8 and 98.5 per cent, respectively, of all colored farmers are Negroes (see Table 9), quite generally reported their freedom from or their encumbrance with farm mortgages. In the South 60.4 per cent of the owners reported their farms free from mortgages; 29.9 per cent reported mortgages, and only 9.7 per cent failed to report. In the North, where values are generally higher than in the South (see Table 27), the selected States reported 49.1 per cent free; 45.5 per cent mortgaged, while no reports were received from 5.4 per cent of the owners.

A comparison of the States forming the South shows that West Virginia followed, in the order named, by Florida and Virginia, reported the highest percentages of wholly owned farms free from mortgage, and that exclusive of the almost negligible District of Columbia, the State of Mississippi reported the highest percentage of mortgaged farms, followed by Delaware and Arkansas. In the North, the State of Missouri closely followed by Ohio, reported the highest percentage of fully owned farms free from mortgage, while Pennsylvania followed by New Jersey reported the highest percentages of farms mortgaged. 
Table 32.-Farms Operated by Colored Full Owners, Classified According to Mortgage Status, by Southern Divisions and States, and Selected Northern States, 1930

[Flgures relate only to farms wholly owned by their operators]

\begin{tabular}{|c|c|c|c|c|c|c|c|}
\hline \multirow{3}{*}{ DIVISION AND STATE } & \multicolumn{7}{|c|}{ FARMS OPERATED BY COLORED FULL OWNERS } \\
\hline & \multirow[b]{2}{*}{ Total } & \multirow[b]{2}{*}{$\begin{array}{c}\text { Report- } \\
\text { ed free } \\
\text { from } \\
\text { mortgage }\end{array}$} & \multirow[b]{2}{*}{$\begin{array}{l}\text { Report- } \\
\text { ed mort- } \\
\text { gaged }\end{array}$} & \multirow[b]{2}{*}{$\begin{array}{l}\text { Un- } \\
\text { known } \\
\text { (no } \\
\text { report) }\end{array}$} & \multicolumn{3}{|c|}{ Per cent distribution } \\
\hline & & & & & $\begin{array}{l}\text { Report- } \\
\text { ed free } \\
\text { from } \\
\text { mortgage }\end{array}$ & $\begin{array}{l}\text { Report- } \\
\text { ed mort- } \\
\text { gaged }\end{array}$ & $\begin{array}{l}\text { Un- } \\
\text { known } \\
\text { (no } \\
\text { report) }\end{array}$ \\
\hline The South..... & 140,496 & 84,861 & 41,964 & 13,671 & 60.4 & 29.8 & 9.7 \\
\hline South Atlantic... & 60,714 & 39,887 & 15,860 & 4,967 & 65.7 & 26.1 & 8.2 \\
\hline $\begin{array}{l}\text { Delaware } \\
\text { Maryland } \\
\text { District of Columbia. } \\
\text { Virginia. } \\
\text { West Virginia. } \\
\text { North Carolina....... } \\
\text { South Carolina } \\
\text { Georgia........ } \\
\text { Florida }\end{array}$ & $\begin{array}{r}309 \\
2,362 \\
7 \\
19,200 \\
328 \\
13,198 \\
11,937 \\
9,014 \\
4,359\end{array}$ & $\begin{array}{r}162 \\
1,449 \\
2 \\
14,077 \\
258 \\
7,671 \\
7,745 \\
5,311 \\
3,212\end{array}$ & $\begin{array}{r}124 \\
814 \\
3 \\
4,184 \\
48 \\
4,258 \\
3,263 \\
2,541 \\
625\end{array}$ & $\begin{array}{r}23 \\
99 \\
2 \\
939 \\
22 \\
1,269 \\
929 \\
1,162 \\
522\end{array}$ & $\begin{array}{l}52.4 \\
61.3 \\
28.6 \\
73.3 \\
78.7 \\
58.1 \\
64.9 \\
58.9 \\
73.7\end{array}$ & $\begin{array}{l}40.1 \\
34.5 \\
42.9 \\
21.8 \\
14.6 \\
32.3 \\
27.3 \\
28.2 \\
14.3\end{array}$ & $\begin{array}{r}7.4 \\
4.2 \\
28.6 \\
4.9 \\
6.7 \\
9.6 \\
7.8 \\
12.9 \\
12.0\end{array}$ \\
\hline East South Central.. & 39,420 & 20,659 & 15,087 & 3,674 & 52.4 & 38.3 & 9.3 \\
\hline $\begin{array}{l}\text { Kentucky } \\
\text { Tennessee } \\
\text { Alabama } \\
\text { Mississippi............. }\end{array}$ & $\begin{array}{r}3,055 \\
5,687 \\
11,417 \\
19,261\end{array}$ & $\begin{array}{l}1,898 \\
3,456 \\
6,140 \\
9,165\end{array}$ & $\begin{array}{r}682 \\
1,639 \\
4,135 \\
8,631\end{array}$ & $\begin{array}{r}475 \\
592 \\
1,142 \\
1,465\end{array}$ & $\begin{array}{l}62.1 \\
60.8 \\
53.8 \\
47.6\end{array}$ & $\begin{array}{l}22.3 \\
28.8 \\
36.2 \\
44.8\end{array}$ & $\begin{array}{r}15.5 \\
10.4 \\
10.0 \\
7.6\end{array}$ \\
\hline West South Central _. & 40,362 & 24,315 & 11,017 & 5,030 & 60.2 & 27.3 & 12.5 \\
\hline $\begin{array}{l}\text { Arkansas } \\
\text { Lousiana..... } \\
\text { Okeahoma. } \\
\text { Texas... }\end{array}$ & $\begin{array}{r}9,058 \\
8,786 \\
6,550 \\
15,968\end{array}$ & $\begin{array}{r}4,521 \\
5,080 \\
3,682 \\
11,032\end{array}$ & $\begin{array}{l}3,496 \\
2,659 \\
1,604 \\
3,258\end{array}$ & $\begin{array}{l}1,041 \\
1,047 \\
1,264 \\
1,678\end{array}$ & $\begin{array}{l}49.9 \\
57.8 \\
56.2 \\
69.1\end{array}$ & $\begin{array}{l}38.6 \\
30.3 \\
24.5 \\
20.4\end{array}$ & $\begin{array}{l}11.5 \\
11.9 \\
19.3 \\
10.5\end{array}$ \\
\hline Selccted Northern States 1 & 2,790 & 1,369 & 1,270 & 151 & 49.1 & 45.5 & 5.4 \\
\hline $\begin{array}{l}\text { New Jersey } \\
\text { Pennsylvania } \\
\text { Ohlo } \\
\text { Indiana } \\
\text { Illinois } \\
\text { Míssouri } \\
\text { Kansas. }\end{array}$ & $\begin{array}{l}217 \\
221 \\
640 \\
207 \\
309 \\
815 \\
381\end{array}$ & $\begin{array}{r}103 \\
91 \\
324 \\
95 \\
150 \\
416 \\
190\end{array}$ & \begin{tabular}{r|r|}
107 \\
121 \\
265 \\
97 \\
140 \\
370 \\
170
\end{tabular} & $\begin{array}{r}7 \\
9 \\
51 \\
15 \\
19 \\
29 \\
21\end{array}$ & $\begin{array}{l}47.5 \\
41.2 \\
50.6 \\
45.9 \\
48.5 \\
51.0 \\
49.9\end{array}$ & $\begin{array}{l}49.3 \\
54.8 \\
41.4 \\
46.9 \\
45.3 \\
45.4 \\
44.6\end{array}$ & $\begin{array}{l}3.2 \\
4.1 \\
8.0 \\
7.2 \\
6.1 \\
3.6 \\
5.5\end{array}$ \\
\hline
\end{tabular}

1 States having 200 or more Negro farmers who constitute 90 per cent or more of the colored farm operators in the State.

Implements and machinery.-The value of farm implements and machinery is the combined value of automobiles, trucks, tractors, tools, wagons, harnesses, dairy equipment, cotton gins, threshing machines, combines, apparatus for making cider, grape juice, sirup, and for drying fruits, and all other machinery. The value of commercial mills and factories located on the farm was not included. The $\mathbf{1 9 3 0}$ average value per farm of implements and machinery for the United States was $\$ 525$; for the North $\$ 845$; the South $\$ 216$, and the West $\$ 874$.

Increased use by Negro farmers.-Table 33 shows that the value of implements and machinery on farms operated by Negroes in 1930 , amounted to $\$ 60,327,856$. This is an average of $\$ 68$ per farm as compared with $\$ 38$ in 1910 and $\$ 25$ in 1900 (no 1920 data available). Dividing the country into sections, the North reported an average value of $\$ 178$ in 1930 as compared with $\$ 110$ in 1910 and $\$ 66$ in 1900; the South gave an average value per farm of $\$ 67$ in 1930 as compared with $\$ 37$ in 1910 and $\$ 24$ in 1900 , and in the West the average value was $\$ 351$ for 1930 , $\$ 208$ in 1910 and $\$ 107$ at the census of 1900 . 
For Negro farm owners the average value per farm of implements and machinery was decidedly higher than the average of $\$ 57$ for farms operated by tenants. As indicated in Table 33, the average value for the United States was $\$ 109$, for the North $\$ 236$, for the South $\$ 106$, and for the West $\$ 310$. Nebraska with an average value of $\$ 1,324$ ranked in first place, followed in the order named, by Idaho, Montana, and Minnesota, with a verage values of $\$ 961, \$ 959$, and $\$ 920$, respectively. Seven other States, including Nevada, New York, North Dakota, South Dakota, Vermont, Wisconsin, and Wyoming reported average values per farm ranging from $\$ 500$ in Nevada to $\$ 882$ in South Dakota. The highest average value of farm implements and machinery per owned farm in the South was $\$ 270$ for Delaware, and the lowest was $\$ 71$ for West Virginia.

Table 33.-Valde of Implements and Machinery on Farms Operated by Negroes, by Tendre, by Sections, Divisions, and States, 1930

\begin{tabular}{|c|c|c|c|c|c|}
\hline \multirow[b]{2}{*}{ SECTION, DIVISION, AND STATE } & \multicolumn{5}{|c|}{ VALUE OF IMPLEMENTS AND MACHINERT } \\
\hline & Total & Owners & Tenants & Managers & $\begin{array}{l}\text { A ver- } \\
\text { age value } \\
\text { per } \\
\text { owned } \\
\text { farm }\end{array}$ \\
\hline United States................. & $\$ 80, \$ 27,856$ & $818,784,411$ & $\$ 39,820,395$ & 8628,050 & 8108 \\
\hline $\begin{array}{l}\text { The North } \\
\text { The South } \\
\text { The West }\end{array}$ & $\begin{array}{r}1,971,346 \\
58,072,123 \\
284,387 \\
\end{array}$ & $\begin{array}{r}1,042,391 \\
18,598,940 \\
143,080 \\
\end{array}$ & $\begin{array}{r}855,340 \\
38,945,123 \\
119,932 \\
\end{array}$ & $\begin{array}{r}73,615 \\
528,060 \\
21,375 \\
\end{array}$ & $\begin{array}{l}236 \\
106 \\
310 \\
\end{array}$ \\
\hline 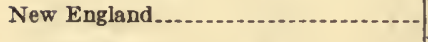 & 57,730 & 44,105 & 4,625 & 9,000 & 345 \\
\hline $\begin{array}{l}\text { Maine } \\
\text { New Hampshire } \\
\text { Massachusetts.... } \\
\text { Rhode Island } \\
\text { Connecticut..... }\end{array}$ & $\begin{array}{r}6,075 \\
2,050 \\
18,525 \\
19,320 \\
2,025 \\
9,735\end{array}$ & $\begin{array}{r}4,575 \\
1,800 \\
12,525 \\
16,645 \\
7,735\end{array}$ & $\begin{array}{r}1,500 \\
250 \\
1,000 \\
275 \\
1,600\end{array}$ & $\begin{array}{r}5,000 \\
2,400 \\
1,200 \\
400\end{array}$ & $\begin{array}{l}327 \\
360 \\
737 \\
223 \\
108 \\
309\end{array}$ \\
\hline Middle Atlantic.................. & 414,576 & 235,976 & 154,140 & 24,460 & 415 \\
\hline $\begin{array}{l}\text { New York... } \\
\text { New Jersey }\end{array}$ & $\begin{array}{r}95,725 \\
173,223 \\
145,628\end{array}$ & $\begin{array}{l}61,065 \\
88,123 \\
86,788\end{array}$ & $\begin{array}{l}30,260 \\
69,750 \\
54,130\end{array}$ & $\begin{array}{r}4,400 \\
15,350 \\
4,710\end{array}$ & $\begin{array}{l}545 \\
380 \\
387\end{array}$ \\
\hline East North Central & 584,661 & 348,235 & 211,791 & 24,635 & 184 \\
\hline $\begin{array}{l}\text { Ohio } \\
\text { Indians } \\
\text { Illinois } \\
\text { Michigan } \\
\text { Wisconsin..... }\end{array}$ & $\begin{array}{r}217,013 \\
77,162 \\
126,810 \\
137,755 \\
25,921\end{array}$ & $\begin{array}{r}118,645 \\
37,982 \\
63,677 \\
106,595 \\
21,336\end{array}$ & $\begin{array}{r}85,743 \\
38,330 \\
54,683 \\
28,450 \\
4,585\end{array}$ & $\begin{array}{r}12,625 \\
850 \\
8,450 \\
2,710 \\
\end{array}$ & $\begin{array}{l}152 \\
138 \\
139 \\
316 \\
520\end{array}$ \\
\hline West North Central .......................... & 914,379 & 414,075 & 484,784 & 15,520 & 226 \\
\hline $\begin{array}{l}\text { Minnesota. } \\
\text { Iowa } \\
\text { Missouri } \\
\text { North Dakota. } \\
\text { South Dakota... } \\
\text { Nebraska... } \\
\text { Kansas }\end{array}$ & $\begin{array}{r}18,965 \\
46,001 \\
493,459 \\
7,875 \\
32,570 \\
28,434 \\
287,075\end{array}$ & $\begin{array}{r}17,475 \\
20,271 \\
143,101 \\
3,175 \\
22,920 \\
21,178 \\
185,955\end{array}$ & $\begin{array}{r}1,490 \\
25,730 \\
339,083 \\
4,700 \\
8,650 \\
7,256 \\
97,875\end{array}$ & $\begin{array}{r}11,275 \\
1,000 \\
3,245\end{array}$ & $\begin{array}{r}920 \\
303 \\
123 \\
635 \\
882 \\
1,324 \\
344\end{array}$ \\
\hline South Atlantic & $19,328,688$ & $7,388,829$ & $11,648,568$ & 291,291 & 93 \\
\hline $\begin{array}{l}\text { Delaware } \\
\text { Maryland } \\
\text { District of Columbia } \\
\text { Virginia } \\
\text { West Virginia. } \\
\text { North Carolina. } \\
\text { South Carolina } \\
\text { Georgia } \\
\text { Florida }\end{array}$ & $\begin{array}{r}224,010 \\
945,402 \\
1,225 \\
3,865,540 \\
47,007 \\
5,155,245 \\
4,081739 \\
4,320,997 \\
687,523\end{array}$ & $\begin{array}{r}100,745 \\
423,994 \\
100 \\
2,586,923 \\
26,570 \\
1,697,834 \\
1,262,222 \\
880,607 \\
409,834\end{array}$ & $\begin{array}{r}107,075 \\
440,104 \\
125 \\
1,213,240 \\
15,287 \\
3,439,906 \\
2,791,449 \\
3,392,733 \\
248,649\end{array}$ & $\begin{array}{r}16,190 \\
81,304 \\
1,000 \\
65,377 \\
5,150 \\
17,505 \\
28,068 \\
47,657 \\
29,040\end{array}$ & $\begin{array}{r}270 \\
144 \\
13 \\
106 \\
71 \\
89 \\
79 \\
79 \\
74\end{array}$ \\
\hline
\end{tabular}


Table 33.-Value of Implements and Machinert on Farms Operated by Negroes, by Tenure, by Sections, Divisions, and States, 1930 -Con.

\begin{tabular}{|c|c|c|c|c|c|}
\hline \multirow[b]{2}{*}{ SECTION, DIVISION, AND STATE } & \multicolumn{5}{|c|}{ VALUE OF IMPLEMENTS AND MACENERY } \\
\hline & Total & Owners & Tenants & Managers & $\begin{array}{l}\text { Aver- } \\
\text { age value } \\
\text { per } \\
\text { owned } \\
\text { farm }\end{array}$ \\
\hline East South Centr & $\$ 19,776,031$ & $\$ 5,560,624$ & $\$ 14,087,943$ & $\$ 127,464$ & $\$ 110$ \\
\hline $\begin{array}{l}\text { Kentucky } \\
\text { Tennessee } \\
\text { Alabams } \\
\text { Mississippi. }\end{array}$ & $\begin{array}{r}605,430 \\
2,978,809 \\
5,091,581 \\
11,100,211\end{array}$ & $\begin{array}{r}315,392 \\
941,349 \\
1,549,249 \\
2,754,634\end{array}$ & $\begin{array}{r}281,988 \\
2,016,755 \\
3,516,133 \\
8,273,067\end{array}$ & $\begin{array}{r}8,050 \\
20,705 \\
28,199 \\
72,510\end{array}$ & $\begin{array}{r}76 \\
120 \\
97 \\
122\end{array}$ \\
\hline West South Central. & $18,867,404$ & $5,649,487$ & $13,208,612$ & 109,305 & 123 \\
\hline $\begin{array}{l}\text { Arkansas_-.... } \\
\text { Louisiana_... } \\
\text { Oklahoma_as } \\
\text { Texas_... }\end{array}$ & $\begin{array}{l}4,769,956 \\
4,870,550 \\
1,595,879 \\
7,731,019\end{array}$ & $\begin{array}{r}1,298,051 \\
1,198,264 \\
569,728 \\
2,583,444\end{array}$ & $\begin{array}{l}3,455,510 \\
3,648,111 \\
1,005,601 \\
5,099,390\end{array}$ & $\begin{array}{l}16,395 \\
24,175 \\
20,550 \\
48,185\end{array}$ & $\begin{array}{l}113 \\
114 \\
165 \\
126\end{array}$ \\
\hline Mountain..... & 112,654 & 63,502 & 42, 252 & 6,900 & 347 \\
\hline $\begin{array}{l}\text { Montans.... } \\
\text { Idaho } \\
\text { Wyoming } \\
\text { Colorado } \\
\text { New Mexico M } \\
\text { Arizona. } \\
\text { Utah } \\
\text { Nevada. }\end{array}$ & $\begin{array}{r}15,590 \\
14,125 \\
7,925 \\
23,097 \\
18,187 \\
32,175 \\
305 \\
1,250\end{array}$ & $\begin{array}{r}14,390 \\
6,725 \\
6,025 \\
12,835 \\
9,277 \\
12,945 \\
305 \\
1,000\end{array}$ & $\begin{array}{r}1,200 \\
2,400 \\
1,900 \\
10,262 \\
8,910 \\
17,330 \\
250\end{array}$ & $\begin{array}{r}5,000 \\
1,900 \\
\end{array}$ & $\begin{array}{r}959 \\
961 \\
753 \\
238 \\
175 \\
324 \\
76 \\
500\end{array}$ \\
\hline Pacific... & 171,733 & 79,578 & 77,680 & 14,475 & 285 \\
\hline 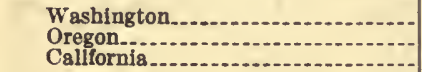 & $\begin{array}{r}22,740 \\
2,667 \\
146,326\end{array}$ & $\begin{array}{r}15,615 \\
2,617 \\
61,346\end{array}$ & $\begin{array}{r}5,125 \\
50 \\
72,505\end{array}$ & $\begin{array}{r}2,000 \\
12,475\end{array}$ & $\begin{array}{l}256 \\
327 \\
292\end{array}$ \\
\hline
\end{tabular}

Machinery distribution in Southern and selected Northern States.-The distribution of specified farm machinery on farms of colored operators (see introduction to Table 9) is presented in Table 34 for the South and seven Northern States. An apportionment by States is made of 190,226 automobiles, 11,739 motor trucks, 2,936 tractors, 422 electric motors for farm work, and 2,040 stationary gas engines. Colored farmers in Mississippi had 33,359 automobiles; in North Carolina they had 23,859; and in Texas, 22,339. Mississippi also led in the number $(1,591)$ of motor trucks while Virginia and Texas occupied second and third places. North Carolina reported the largest number of tractors, followed by Oklahoma and Virginia. Oklahoma, Virginia, and Texas, in the order named, reported more electric motors for farm work than any other States, and the colored farmers in Virginia occupied first rank in the number of stationary gas engines. In the North, Missouri ranked in first place in the number of automobiles on farms of colored operators; New Jersey in the number of motor trucks; Kansas in tractors; and New Jersey again, in electric motors for farm work and in stationary gas engines.

On the farms in the South there was an average of 4.7 colored farmers as compared with 2 white farmers per automobile. For motor trucks the averages were 79.7 colored and 10.4 white farmers per truck. In the seven selected Northern States the averages were somewhat lower, colored farmers averaging 2.8 , and white farmers 1.1 per automobile; while for motor trucks there were 15.1 colored, and 5.5 white farmers per truck. 
Table 34.-Farm Machinery Reported by Colored Farm Operators in The Sodthern Divisions and States, and in Selected Northern States 1930

\begin{tabular}{|c|c|c|c|c|c|c|}
\hline \multirow[b]{2}{*}{$\begin{array}{l}\text { SECTION, DIVISION, AND } \\
\text { STATE }\end{array}$} & \multicolumn{6}{|c|}{ NUMBER OF- } \\
\hline & $\underset{\text { biles }}{\text { Automo- }}$ & $\begin{array}{l}\text { Motor } \\
\text { trucks }\end{array}$ & Tractors & $\begin{array}{l}\text { Eloctric } \\
\text { motors for } \\
\text { farm work }\end{array}$ & $\begin{array}{l}\text { Stationary } \\
\text { gas engines }\end{array}$ & $\begin{array}{l}\text { Farmers } \\
\text { per auto- } \\
\text { mobile }\end{array}$ \\
\hline The South.. & 186,518 & 11,062 & 2,533 & 363 & 1,681 & 4.7 \\
\hline South Atlantic.. & 78,764 & 5,101 & 1,221 & 137 & 1,008 & 3.8 \\
\hline $\begin{array}{l}\text { Delaware } \\
\text { Maryland } \\
\text { District of Columbia }\end{array}$ & $\begin{array}{r}524 \\
2,629\end{array}$ & $\begin{array}{r}81 \\
413\end{array}$ & $\begin{array}{r}36 \\
157 \\
1\end{array}$ & $\begin{array}{r}1 \\
20\end{array}$ & $\begin{array}{r}35 \\
118\end{array}$ & $\begin{array}{l}1.5 \\
2.0\end{array}$ \\
\hline $\begin{array}{l}\text { Virginia } \\
\text { West Virginia. } \\
\text { North Carolina... } \\
\text { South Carolina } \\
\text { Georgia. } \\
\text { Florida }\end{array}$ & $\begin{array}{r}13,870 \\
149 \\
23,859 \\
18,901 \\
16,757 \\
2,075\end{array}$ & $\begin{array}{r}1,357 \\
29 \\
1,072 \\
641 \\
865 \\
643\end{array}$ & $\begin{array}{r}291 \\
6 \\
373 \\
100 \\
182 \\
75\end{array}$ & $\begin{array}{r}30 \\
2 \\
22 \\
28 \\
20 \\
14\end{array}$ & $\begin{array}{r}396 \\
9 \\
131 \\
93 \\
163 \\
63\end{array}$ & $\begin{array}{l}2.9 \\
3.3 \\
3.2 \\
4.1 \\
5.2 \\
5.3\end{array}$ \\
\hline East South Central.. & 56,039 & 2,673 & 514 & 55 & 213 & 5.7 \\
\hline $\begin{array}{l}\text { Kentucky } \\
\text { Tennessee........ } \\
\text { Alabams } \\
\text { Mississippi. }\end{array}$ & $\begin{array}{r}2,384 \\
7,762 \\
12,534 \\
33,359\end{array}$ & $\begin{array}{r}83 \\
269 \\
730 \\
1,591\end{array}$ & $\begin{array}{r}53 \\
94 \\
124 \\
243\end{array}$ & $\begin{array}{r}1 \\
13 \\
25 \\
16\end{array}$ & $\begin{array}{l}29 \\
41 \\
66 \\
77\end{array}$ & $\begin{array}{l}3.8 \\
4.5 \\
7.5 \\
5.5\end{array}$ \\
\hline West South Central.- & 51,715 & 3,288 & 798 & 171 & 460 & 5.1 \\
\hline $\begin{array}{l}\text { Arkansas } \\
\text { Louisiana } \\
\text { Oklahoma. } \\
\text { Texas........... }\end{array}$ & $\begin{array}{r}11,197 \\
10,933 \\
7,246 \\
22,339\end{array}$ & $\begin{array}{r}618 \\
684 \\
669 \\
1,317\end{array}$ & $\begin{array}{l}124 \\
137 \\
295 \\
242\end{array}$ & $\begin{array}{r}24 \\
15 \\
103 \\
29\end{array}$ & $\begin{array}{r}63 \\
89 \\
189 \\
119\end{array}$ & $\begin{array}{l}7.1 \\
6.7 \\
3.2 \\
3.9\end{array}$ \\
\hline Selected Northern States $1 . .$. & 3,708 & 677 & 403 & 59 & 359 & 2.8 \\
\hline $\begin{array}{l}\text { New Jersey } \\
\text { Pennsylvania. } \\
\text { Ohio } \\
\text { Indians } \\
\text { Illinois } \\
\text { Missouri } \\
\text { Kansas }\end{array}$ & $\begin{array}{r}249 \\
203 \\
663 \\
245 \\
253 \\
1,461 \\
634\end{array}$ & $\begin{array}{r}173 \\
68 \\
127 \\
50 \\
62 \\
81 \\
116\end{array}$ & $\begin{array}{r}41 \\
33 \\
96 \\
42 \\
31 \\
60 \\
100\end{array}$ & $\begin{array}{r}15 \\
6 \\
12 \\
4 \\
6 \\
3 \\
13\end{array}$ & $\begin{array}{l}67 \\
46 \\
66 \\
29 \\
29 \\
57 \\
65\end{array}$ & $\begin{array}{l}1.5 \\
1.8 \\
1.9 \\
1.9 \\
3.5 \\
4.0 \\
1.6\end{array}$ \\
\hline
\end{tabular}

1 States having 200 or more Negro farmers who constitute 90 per cent or more of the colored farm operators in the State. 
Table 35.-Number of Negro Farm Operators, by [A minus sign (-)

\begin{tabular}{|c|c|c|c|c|c|c|c|c|c|}
\hline & \multirow{3}{*}{$\begin{array}{l}\text { SECTION, DIVISION, AND } \\
\text { STATE }\end{array}$} & \multicolumn{8}{|c|}{ NUMBER OF NEGRO FARM OPERATORS } \\
\hline & & \multicolumn{2}{|c|}{ Total } & \multicolumn{2}{|c|}{ Owners } & \multicolumn{2}{|c|}{ Tenants } & \multicolumn{2}{|c|}{ Managers } \\
\hline & & 1930 & 1920 & 1930 & 1920 & 1930 & 1920 & 1930 & 1920 \\
\hline 1 & United States........ & 882,850 & 925,708 & 181,016 & 218,812 & 700,911 & 705,070 & 923 & 2,026 \\
\hline $\begin{array}{l}2 \\
3 \\
4\end{array}$ & $\begin{array}{l}\text { The North } \\
\text { The South....... } \\
\text { The West...... }\end{array}$ & $\begin{array}{r}11,104 \\
870,936 \\
810 \\
\end{array}$ & $\begin{array}{r}9,380 \\
915,595 \\
733 \\
\end{array}$ & $\begin{array}{r}4,424 \\
176,130 \\
462 \\
\end{array}$ & $\begin{array}{r}5,749 \\
212,365 \\
498 \\
\end{array}$ & $\begin{array}{r}6,588 \\
694,001 \\
322 \\
\end{array}$ & $\begin{array}{r}3,389 \\
701,471 \\
210 \\
\end{array}$ & $\begin{array}{r}92 \\
805 \\
26 \\
\end{array}$ & $\begin{array}{r}242 \\
1,759 \\
25 \\
\end{array}$ \\
\hline 5 & New England ............... & 148 & 242 & 128 & 192 & 14 & 33 & 6 & 17 \\
\hline $\begin{array}{r}6 \\
7 \\
8 \\
9 \\
10 \\
11\end{array}$ & $\begin{array}{l}\text { Maine } \\
\text { Vermont Hamphire } \\
\text { Massachusetts......... } \\
\text { Rhode Island........ } \\
\text { Connecticut. }\end{array}$ & $\begin{array}{r}15 \\
6 \\
22 \\
63 \\
9 \\
33\end{array}$ & $\begin{array}{r}13 \\
14 \\
28 \\
103 \\
19 \\
65\end{array}$ & $\begin{array}{r}14 \\
5 \\
17 \\
59 \\
8 \\
25\end{array}$ & $\begin{array}{l}13 \\
12 \\
21 \\
89 \\
13 \\
44\end{array}$ & $\begin{array}{r}1 \\
-\quad 4 \\
4 \\
5\end{array}$ & $\begin{array}{r}1 \\
4 \\
7 \\
5 \\
16\end{array}$ & $\begin{array}{r}1 \\
1 \\
1 \\
3\end{array}$ & $\begin{array}{l}1 \\
3 \\
7 \\
1 \\
5\end{array}$ \\
\hline 12 & Middje Atiantic & 873 & 1,227 & 568 & 697 & 274 & 444 & 31 & 88 \\
\hline $\begin{array}{l}13 \\
14 \\
15\end{array}$ & $\begin{array}{l}\text { New York. } \\
\text { New Jersey } \\
\text { Pennsylvania............. }\end{array}$ & $\begin{array}{l}148 \\
372 \\
353\end{array}$ & $\begin{array}{l}245 \\
531 \\
451\end{array}$ & $\begin{array}{l}112 \\
232 \\
224\end{array}$ & $\begin{array}{l}152 \\
284 \\
261\end{array}$ & $\begin{array}{r}33 \\
126 \\
115\end{array}$ & $\begin{array}{r}71 \\
228 \\
145\end{array}$ & $\begin{array}{r}3 \\
14 \\
14\end{array}$ & $\begin{array}{l}22 \\
10 \\
45\end{array}$ \\
\hline 16 & East North Central.......- & 3,065 & 3,674 & 1,892 & 2,335 & 1,149 & 1,273 & 24 & 66 \\
\hline $\begin{array}{l}17 \\
18 \\
19 \\
20 \\
21\end{array}$ & $\begin{array}{l}\text { Obio } \\
\text { Indianais } \\
\text { Michigan } \\
\text { Wisconsin. }\end{array}$ & $\begin{array}{r}1,229 \\
461 \\
893 \\
427 \\
55\end{array}$ & $\begin{array}{r}1,616 \\
570 \\
892 \\
549 \\
47\end{array}$ & $\begin{array}{r}780 \\
275 \\
459 \\
337 \\
41\end{array}$ & $\begin{array}{r}1,053 \\
305 \\
533 \\
403 \\
41\end{array}$ & $\begin{array}{r}438 \\
184 \\
428 \\
85 \\
14\end{array}$ & $\begin{array}{r}527 \\
251 \\
350 \\
139 \\
6\end{array}$ & $\begin{array}{r}11 \\
2 \\
6 \\
5 \\
\end{array}$ & $\begin{array}{r}36 \\
14 \\
9 \\
7 \\
\end{array}$ \\
\hline 22 & West North Central...... & 7,018 & 4,237 & 1,836 & 2,525 & 5,151 & 1,639 & 31 & 73 \\
\hline $\begin{array}{l}23 \\
24 \\
25 \\
26 \\
27 \\
28 \\
29\end{array}$ & $\begin{array}{l}\text { Minnesota. } \\
\text { Missouri } \\
\text { North Dakota. } \\
\text { South Dakota... } \\
\text { Nebraska.... } \\
\text { Kansas }\end{array}$ & $\begin{array}{r}27 \\
118 \\
5,844 \\
10 \\
40 \\
38 \\
941\end{array}$ & $\begin{array}{r}33 \\
109 \\
2,824 \\
26 \\
47 \\
63 \\
1,135\end{array}$ & $\begin{array}{r}19 \\
67 \\
1,163 \\
5 \\
26 \\
16 \\
540\end{array}$ & \begin{tabular}{|r|}
24 \\
74 \\
1,643 \\
11 \\
33 \\
31 \\
709
\end{tabular} & $\begin{array}{r}8 \\
51 \\
4,661 \\
5 \\
13 \\
22 \\
391\end{array}$ & $\begin{array}{r}34 \\
1,133 \\
13 \\
13 \\
28 \\
409\end{array}$ & (10 & $\begin{array}{r}1 \\
48 \\
2 \\
1 \\
4 \\
17\end{array}$ \\
\hline 30 & South Atlantic . . . & 295,934 & 382,278 & 79,683 & 102,056 & 215,774 & 279,266 & 477 & 956 \\
\hline $\begin{array}{l}31 \\
32 \\
33 \\
34 \\
35 \\
36 \\
37 \\
38 \\
39\end{array}$ & 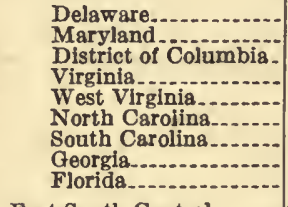 & $\begin{array}{r}807 \\
5,264 \\
11 \\
39,598 \\
490 \\
74,636 \\
77,331 \\
86,787 \\
11,010\end{array}$ & $\begin{array}{r}872 \\
6,208 \\
20 \\
47,690 \\
504 \\
74,849 \\
109,005 \\
130,176 \\
12,954\end{array}$ & $\begin{array}{r}373 \\
2,938 \\
8 \\
24,399 \\
372 \\
18,978 \\
15,975 \\
11,080 \\
5,560\end{array}$ & $\begin{array}{r}355 \\
3,548 \\
9 \\
30,908 \\
403 \\
21,714 \\
22,759 \\
16,040 \\
6,320\end{array}$ & $\begin{array}{r}415 \\
2,206 \\
2 \\
15,123 \\
111 \\
65,635 \\
61,285 \\
75,635 \\
5,362\end{array}$ & $\begin{array}{r}504 \\
2,509 \\
10 \\
16,585 \\
93 \\
53,040 \\
86,063 \\
113,929 \\
6,533\end{array}$ & $\begin{array}{r}19 \\
120 \\
1 \\
76 \\
7 \\
23 \\
71 \\
72 \\
88\end{array}$ & $\begin{array}{r}13 \\
151 \\
1 \\
197 \\
8 \\
95 \\
183 \\
207 \\
101\end{array}$ \\
\hline 40 & East South Central........ & 320,600 & 307,006 & 50,475 & 55,488 & 269,985 & 251,112 & 140 & 406 \\
\hline $\begin{array}{l}41 \\
42 \\
43 \\
44\end{array}$ & $\begin{array}{l}\text { Kentucky } \\
\text { Tennesseo } \\
\text { Alabama } \\
\text { Mississippi }\end{array}$ & $\begin{array}{r}9,104 \\
35,123 \\
93,795 \\
182,578\end{array}$ & $\begin{array}{r}12,624 \\
38,181 \\
95,200 \\
161,001\end{array}$ & $\begin{array}{r}4,175 \\
7,828 \\
15,920 \\
22,552\end{array}$ & $\begin{array}{r}5,318 \\
9,839 \\
17,201 \\
23,130\end{array}$ & $\begin{array}{r}4,914 \\
27,261 \\
77,853 \\
159,957\end{array}$ & $\begin{array}{r}7,271 \\
28,289 \\
77,873 \\
137,679\end{array}$ & $\begin{array}{l}15 \\
34 \\
22 \\
69\end{array}$ & $\begin{array}{r}35 \\
53 \\
126 \\
192\end{array}$ \\
\hline 45 & West South Central...... & 254,402 & 226,311 & 45,972 & 54,821 & 208,242 & 171,093 & 188 & 397 \\
\hline $\begin{array}{l}46 \\
47 \\
48 \\
49\end{array}$ & 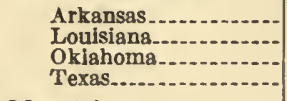 & $\begin{array}{l}79,550 \\
73,734 \\
15,172 \\
85,940\end{array}$ & $\begin{array}{l}72,275 \\
62,038 \\
13,403 \\
78,597\end{array}$ & $\begin{array}{r}11,452 \\
10,488 \\
3,454 \\
20,578\end{array}$ & $\begin{array}{r}15,369 \\
10,975 \\
4,958 \\
23,519\end{array}$ & $\begin{array}{l}68,081 \\
63,192 \\
11,694 \\
65,275\end{array}$ & $\begin{array}{r}56,811 \\
50,969 \\
8,368 \\
54,945\end{array}$ & $\begin{array}{l}23 \\
54 \\
24 \\
87\end{array}$ & $\begin{array}{r}95 \\
92 \\
77 \\
133\end{array}$ \\
\hline 50 & Mountain & 304 & 349 & 183 & 239 & 115 & 100 & 6 & 10 \\
\hline $\begin{array}{l}51 \\
52 \\
53 \\
54 \\
55 \\
56 \\
57 \\
58\end{array}$ & $\begin{array}{l}\text { Montana } \\
\text { W } \text { Womoming } \\
\text { Colorado } \\
\text { New Mexico... } \\
\text { Arizona } \\
\text { Utah } \\
\text { Nevada }\end{array}$ & $\begin{array}{r}21 \\
16 \\
12 \\
78 \\
82 \\
87 \\
5 \\
3\end{array}$ & $\begin{array}{r}31 \\
23 \\
17 \\
148 \\
32 \\
32 \\
61 \\
5\end{array}$ & $\begin{array}{r}15 \\
7 \\
8 \\
54 \\
53 \\
40 \\
4 \\
2\end{array}$ & $\begin{array}{r}26 \\
16 \\
17 \\
115 \\
24 \\
19 \\
19 \\
3\end{array}$ & $\begin{array}{r}6 \\
7 \\
4 \\
23 \\
29 \\
44 \\
1 \\
1\end{array}$ & $\begin{array}{r}4 \\
7 \\
28 \\
8 \\
10 \\
41 \\
2\end{array}$ & 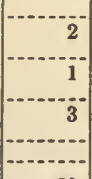 & $\mid \begin{array}{r}1 \\
-3 \\
1 \\
1\end{array}$ \\
\hline 59 & 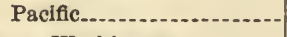 & 508 & 384 & 279 & 259 & 207 & 110 & 20 & 15 \\
\hline $\begin{array}{l}60 \\
61 \\
62\end{array}$ & $\begin{array}{l}\text { Washington } \\
\text { Oregon } \\
\text { California. }\end{array}$ & $\begin{array}{r}73 \\
9 \\
424 \\
\end{array}$ & $\begin{array}{r}79 \\
15 \\
290\end{array}$ & $\begin{array}{r}61 \\
8 \\
210\end{array}$ & $\begin{array}{r}65 \\
11 \\
183\end{array}$ & $\begin{array}{r}10 \\
1 \\
198\end{array}$ & $\begin{array}{r}14 \\
2 \\
94\end{array}$ & 2 & $\begin{array}{r}2 \\
13\end{array}$ \\
\hline
\end{tabular}

1 Less than one-tenth of 1 per cent decrease. 
Tenure, By Sections, Divisions, and States: 1930 and 1920 denotes decreasel

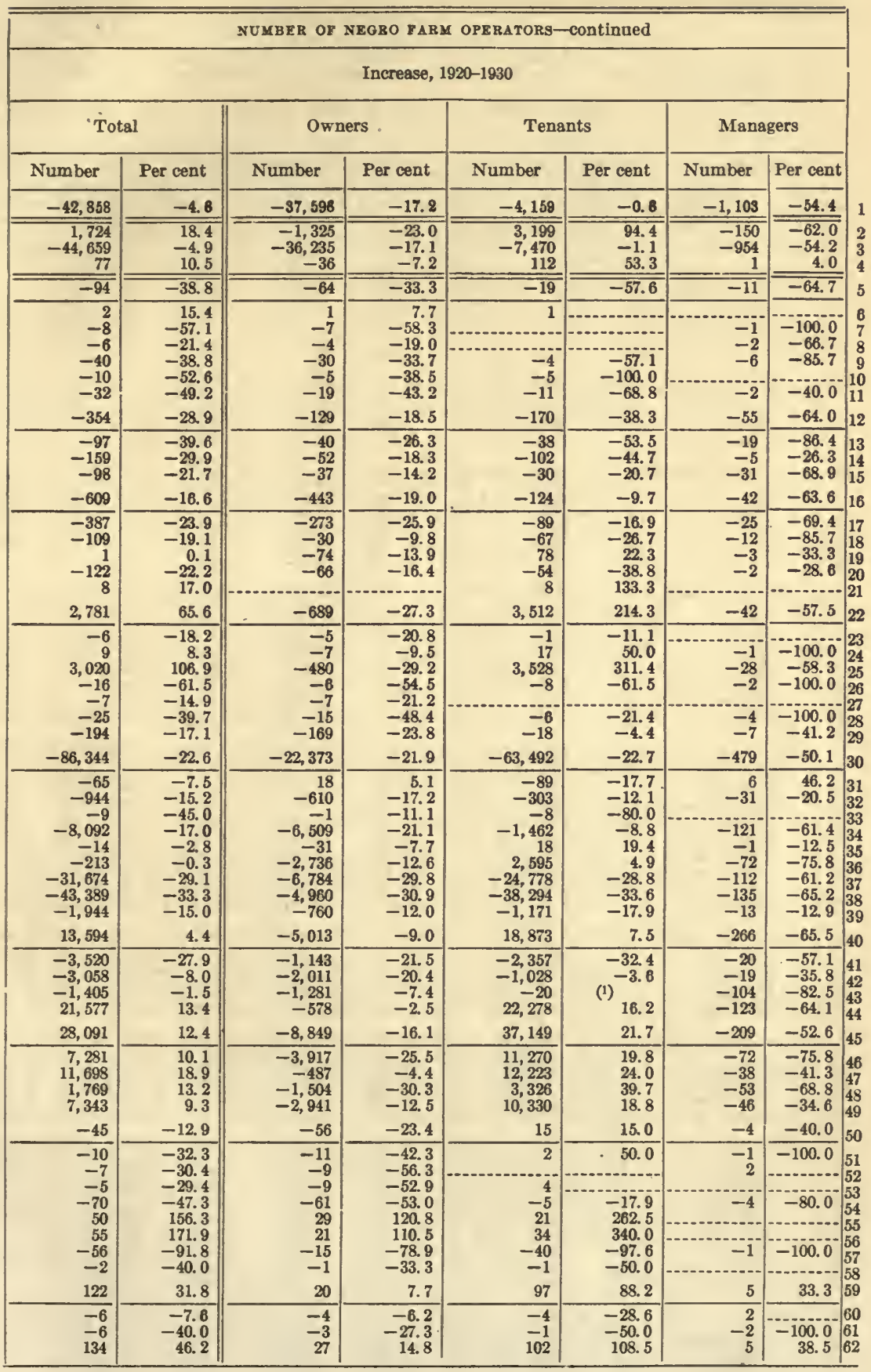


Table 36. - All Land in Farms Operated by Negroes, by

[A minus sign (-)

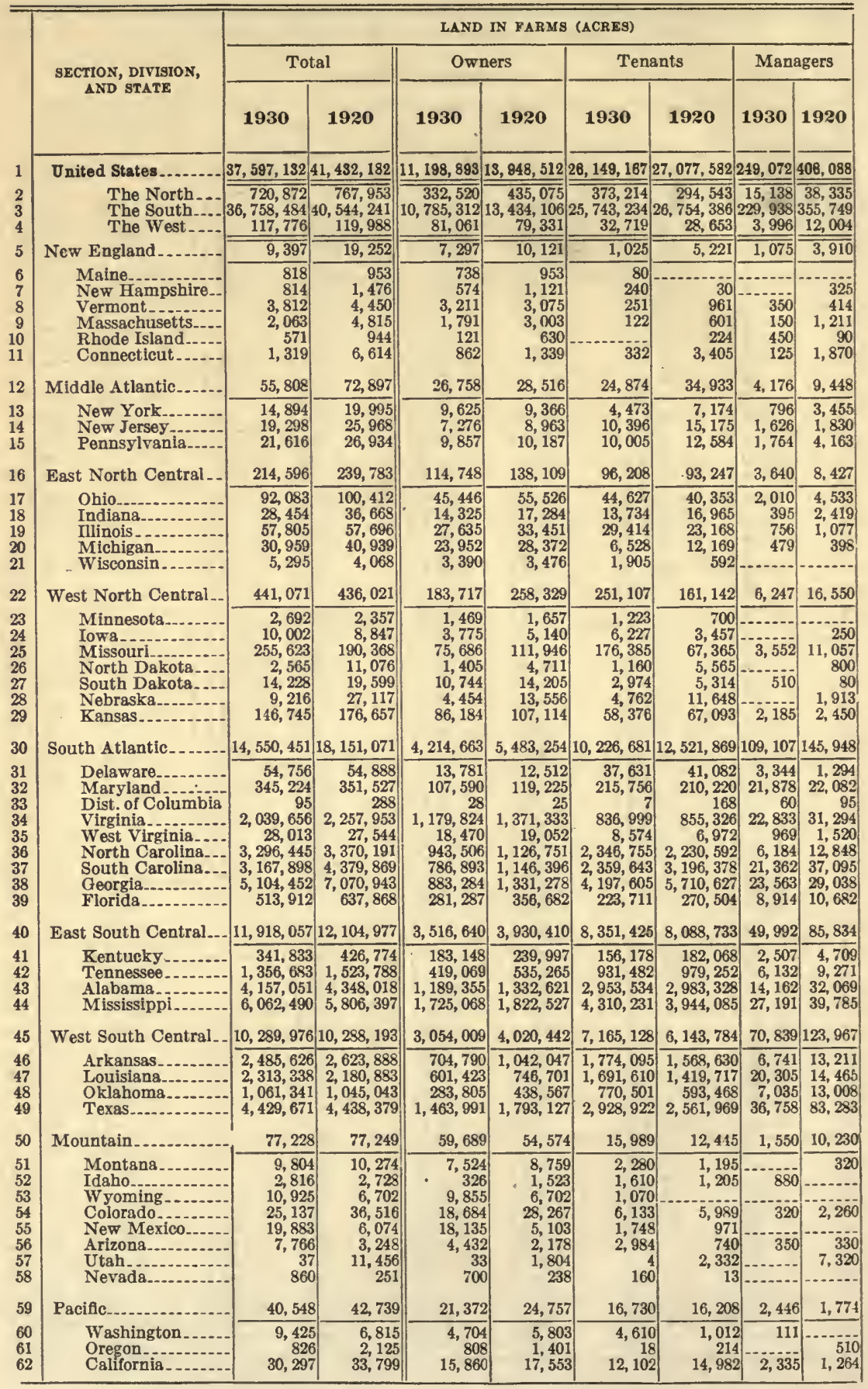

1 Less than one-tenth of 1 per cent.

2 Less than one-tenth of 1 per cent decrease. 
Tenore, by Sections, Divisions, and States: 1930 and 1920

denotes decrease]

\begin{tabular}{|c|c|c|c|c|c|c|c|c|}
\hline \multicolumn{8}{|c|}{ IAND IN FARMS (ACRES) } & \\
\hline \multicolumn{8}{|c|}{ Increase, 1920-1930 } & \\
\hline \multicolumn{2}{|c|}{ Total } & \multicolumn{2}{|c|}{ Owners } & \multicolumn{2}{|c|}{ Tenants } & \multicolumn{2}{|c|}{ Managers } & \\
\hline Acres & Per cent & Acres & Per cent & Acres & Per cent & Acres & Per cent & \\
\hline$-3,835,050$ & -9.3 & $-2,749,619$ & -19.7 & $-928,415$ & -8.4 & $-157,018$ & -88.7 & 1 \\
\hline $\begin{array}{r}-47,081 \\
-3,785,757 \\
-2,212 \\
\end{array}$ & $\begin{array}{l}-6.1 \\
-9.3 \\
-1.8 \\
\end{array}$ & $\begin{array}{r}-102,555 \\
-2,648,794 \\
1,730 \\
\end{array}$ & $\begin{array}{r}-23.6 \\
-19.7 \\
2.2 \\
\end{array}$ & $\begin{array}{r}78,671 \\
-1,011,152 \\
4,066 \\
\end{array}$ & $\begin{array}{r}26.7 \\
-3.8 \\
14.2 \\
\end{array}$ & $\begin{array}{r}-23,197 \\
-125,811 \\
-8,008 \\
\end{array}$ & $\begin{array}{l}-60.5 \\
-35.4 \\
-66.7 \\
\end{array}$ & $\begin{array}{l}2 \\
3 \\
4\end{array}$ \\
\hline$-9,855$ & -51.2 & $-2,824$ & -27.9 & $-4,196$ & -80.4 & $-2,835$ & -72.5 & 5 \\
\hline $\begin{array}{r}-135 \\
-662 \\
-638 \\
-2,752 \\
-373 \\
-5,295\end{array}$ & $\begin{array}{l}-14.2 \\
-44.9 \\
-14.3 \\
-57.2 \\
-39.5 \\
-80.1\end{array}$ & $\begin{array}{r}-215 \\
-547 \\
136 \\
-1,212 \\
-509 \\
-477\end{array}$ & $\begin{array}{l}-22.6 \\
-48.8 \\
4.4 \\
-40.4 \\
-80.8 \\
-35.6\end{array}$ & $\begin{array}{r}80 \\
210 \\
-710 \\
-479 \\
-224 \\
-3,073\end{array}$ & $\begin{array}{r}700.0 \\
-73.9 \\
-79.7 \\
-100.0 \\
-90.2\end{array}$ & $\begin{array}{r}-325 \\
-64 \\
-1,061 \\
360 \\
-1,745\end{array}$ & $\begin{array}{r}-100.0 \\
-15.5 \\
-87.6 \\
400.0 \\
-93.3\end{array}$ & $\begin{array}{r}6 \\
7 \\
8 \\
9 \\
10 \\
11\end{array}$ \\
\hline$-17,089$ & -23.4 & $-1,758$ & -6.2 & $-10,059$ & -28.8 & $-5,272$ & -55.8 & 12 \\
\hline $\begin{array}{l}-5,101 \\
-6,670 \\
-5,318\end{array}$ & $\begin{array}{l}-25.5 \\
-25.7 \\
-19.7\end{array}$ & $\begin{array}{r}259 \\
-1,687 \\
-330\end{array}$ & $\begin{array}{r}2.8 \\
-18.8 \\
-3.2\end{array}$ & $\begin{array}{l}-2,701 \\
-4,779 \\
-2,579\end{array}$ & $\begin{array}{l}-37.6 \\
-31.5 \\
-20.5\end{array}$ & $\begin{array}{r}-2,659 \\
-204 \\
-2,409\end{array}$ & $\begin{array}{l}-77.0 \\
-11.1 \\
-57.9\end{array}$ & $\begin{array}{l}13 \\
14 \\
15\end{array}$ \\
\hline$-25,187$ & -10.5 & $-23,361$ & -16.9 & 2.961 & 3.2 & $-4,787$ & -56.8 & 16 \\
\hline $\begin{array}{r}-8,329 \\
-8,214 \\
109 \\
-9,980 \\
1,227\end{array}$ & \begin{tabular}{r|}
-8.3 \\
-22.4 \\
0.2 \\
-24.4 \\
30.2
\end{tabular} & $\begin{array}{r}-10,080 \\
-2,959 \\
-5,816 \\
-4,420 \\
-86\end{array}$ & $\begin{array}{l}-18.2 \\
-17.1 \\
-17.4 \\
-15.6 \\
-2.5\end{array}$ & $\begin{array}{r}4,274 \\
-3,231 \\
6,246 \\
-5,641 \\
1,313\end{array}$ & $\begin{array}{r}10.6 \\
-19.0 \\
27.0 \\
-46.4 \\
221.8\end{array}$ & $\begin{array}{r}-2,523 \\
-2,024 \\
-321 \\
81\end{array}$ & $\begin{array}{r}-55.7 \\
-83.7 \\
-29.8 \\
20.4\end{array}$ & $\begin{array}{l}17 \\
18 \\
19 \\
20 \\
21\end{array}$ \\
\hline 5,050 & 1.2 & $-74,612$ & -28.9 & 89,965 & 55. 8 & $-10,303$ & -62.3 & 22 \\
\hline $\begin{array}{r}335 \\
1,155 \\
65,255 \\
-8,511 \\
-5,371 \\
-17,901 \\
-29,912\end{array}$ & \begin{tabular}{r|}
14.2 \\
13.1 \\
34.3 \\
-76.8 \\
-27.4 \\
-66.0 \\
-16.9
\end{tabular} & $\begin{array}{r}-188 \\
-1,365 \\
-36,260 \\
-3,306 \\
-3,461 \\
-9,102 \\
-20,930\end{array}$ & $\begin{array}{l}-11.3 \\
-26.6 \\
-32.4 \\
-70.2 \\
-24.4 \\
-67.1 \\
-19.5\end{array}$ & $\begin{array}{r}523 \\
2,770 \\
109,020 \\
-4,405 \\
-2,340 \\
-6,886 \\
-8,717\end{array}$ & $\begin{array}{r}74.7 \\
80.1 \\
161.8 \\
-79.2 \\
-44.0 \\
-59.1 \\
-13.0\end{array}$ & $\begin{array}{r}-250 \\
-7,505 \\
-800 \\
430 \\
-1,913 \\
-265\end{array}$ & $\begin{array}{r}-100.0 \\
-67.9 \\
-100.0 \\
537.5 \\
-100.0 \\
-10.8\end{array}$ & $\begin{array}{l}23 \\
24 \\
25 \\
26 \\
27 \\
28 \\
29\end{array}$ \\
\hline$-3,600,620$ & -19.8 & $-1,268,591$ & -23.1 & $-2,295,188$ & -18.3 & $-36,841$ & -25.2 & 30 \\
\hline $\begin{array}{r}-132 \\
-6,303 \\
-193 \\
-218,297 \\
469 \\
-73,746 \\
-1,211,971 \\
-1,966,491 \\
-123,956\end{array}$ & \begin{tabular}{r|}
-0.2 \\
-1.8 \\
-67.0 \\
-9.7 \\
1.7 \\
-2.2 \\
-27.7 \\
-27.8 \\
-19.4
\end{tabular} & $\begin{array}{r}1,269 \\
-11,635 \\
3 \\
-191,509 \\
-582 \\
-183,245 \\
-359,503 \\
-447,994 \\
-75,395\end{array}$ & $\begin{array}{r}10.1 \\
-9.8 \\
12.0 \\
-14.0 \\
-3.1 \\
-16.3 \\
-31.4 \\
33.7 \\
-21.1\end{array}$ & $\begin{array}{r}-3,451 \\
5,536 \\
-161 \\
-18,327 \\
1,602 \\
116,163 \\
-836,735 \\
-1,513,022 \\
-46,793\end{array}$ & $\begin{array}{r}-8.4 \\
2.6 \\
-95.8 \\
-2.1 \\
23.0 \\
5.2 \\
-26.2 \\
-26.5 \\
-17.3\end{array}$ & $\begin{array}{r}2,050 \\
-204 \\
-35 \\
-8,461 \\
-551 \\
-6,664 \\
-15,733 \\
-5,475 \\
-1,768\end{array}$ & $\begin{array}{r}158.4 \\
-0.9 \\
-36.8 \\
-27.0 \\
-36.3 \\
-51.9 \\
-42.4 \\
-18.9 \\
-16.6\end{array}$ & $\begin{array}{l}31 \\
32 \\
33 \\
34 \\
35 \\
36 \\
37 \\
38 \\
39\end{array}$ \\
\hline$-186,920$ & -1.5 & $-413,770$ & -10.5 & 262,692 & 3.2 & $-35,842$ & -41.8 & 40 \\
\hline $\begin{array}{r}-84,941 \\
-167,105 \\
-190,967 \\
256,093\end{array}$ & $\begin{array}{r}-19.9 \\
-11.0 \\
-4.4 \\
4.4\end{array}$ & $\begin{array}{r}-56,849 \\
-116,196 \\
-143,266 \\
-97,459\end{array}$ & $\begin{array}{r}-23.7 \\
-21.7 \\
-10.8 \\
-5.3\end{array}$ & $\begin{array}{l}-25.890 \\
-47,770 \\
-29,794 \\
366,146\end{array}$ & \begin{tabular}{r|}
-14.2 \\
-4.9 \\
-1.0 \\
9.3
\end{tabular} & $\begin{array}{r}-2,202 \\
-3,139 \\
-17,907 \\
-12,594\end{array}$ & $\begin{array}{l}-46.8 \\
-33.9 \\
-55.8 \\
-31.7\end{array}$ & $\begin{array}{l}41 \\
42 \\
43 \\
44\end{array}$ \\
\hline 1,783 & (1) & $-966,433$ & -24.0 & $1,021,344$ & 16.6. & $-53,128$ & -42.9 & 45 \\
\hline $\begin{array}{r}-138,262 \\
132,455 \\
16,298 \\
-8,708\end{array}$ & $\begin{array}{r}-5.3 \\
6.1 \\
1.6 \\
-0.2\end{array}$ & $\begin{array}{l}-337,257 \\
-145,278 \\
-154,762 \\
-329,136\end{array}$ & $\begin{array}{l}-32.4 \\
-19.5 \\
-35.3 \\
-18.4\end{array}$ & $\begin{array}{l}205,465 \\
271,893 \\
177,033 \\
366,953\end{array}$ & $\begin{array}{l}13.1 \\
19.2 \\
29.8 \\
14.3\end{array}$ & $\begin{array}{r}-6,470 \\
5,840 \\
-5,973 \\
-46,525\end{array}$ & $\begin{array}{r}-49.0 \\
40.4 \\
-45.9 \\
-55.9\end{array}$ & $\begin{array}{l}46 \\
47 \\
48 \\
49\end{array}$ \\
\hline-21 & (2) & 5,115 & 9.4 & 3,544 & 28. 5 & $-8,680$ & -84.8 & 50 \\
\hline $\begin{array}{r}-470 \\
88\end{array}$ & $\begin{array}{r}-4.6 \\
3.2\end{array}$ & $\begin{array}{l}-1,235 \\
-1,197\end{array}$ & $\begin{array}{l}-14.1 \\
-78.6\end{array}$ & 1,085 & $\begin{array}{l}90.8 \\
33.6\end{array}$ & $\begin{array}{r}-320 \\
880\end{array}$ & -100.0 & 51 \\
\hline $\begin{array}{r}4,223 \\
-11,379\end{array}$ & $\begin{array}{r}63.0 \\
-31.2\end{array}$ & $\begin{array}{r}3,153 \\
-9,583\end{array}$ & $\begin{array}{r}47.0 \\
-33.9\end{array}$ & $\begin{array}{r}1,070 \\
144 \\
\end{array}$ & 24 & $-1,940$ & -85.8 & $\begin{array}{l}53 \\
54 \\
55\end{array}$ \\
\hline $\begin{array}{r}13,809 \\
4,518\end{array}$ & $\begin{array}{l}227.3 \\
139.1\end{array}$ & $\begin{array}{r}13,032 \\
2,254\end{array}$ & $\begin{array}{l}255.4 \\
103.5\end{array}$ & $\begin{array}{r}777 \\
2,244\end{array}$ & $\begin{array}{r}80.0 \\
303.2\end{array}$ & & 6.1 & $\begin{array}{l}55 \\
56\end{array}$ \\
\hline $\begin{array}{r}-11,419 \\
609\end{array}$ & $\begin{array}{r}-99.7 \\
242.6\end{array}$ & $\begin{array}{r}-1,771 \\
462\end{array}$ & $\begin{array}{r}-98.2 \\
194.1\end{array}$ & $\begin{array}{r}-2,325 \\
147\end{array}$ & $\begin{array}{r}-99.8 \\
1,130.8\end{array}$ & $-7,320$ & -100.0 & $\begin{array}{l}57 \\
58\end{array}$ \\
\hline$-2,191$ & -5.1 & $-3,385$ & -13.7 & 522 & 3.2 & 672 & 37.9 & 59 \\
\hline $\begin{array}{r}2,610 \\
-1,299 \\
-3,502\end{array}$ & $\begin{array}{r}38.3 \\
-61.1 \\
-10.4\end{array}$ & $\begin{array}{r}-1,099 \\
-593 \\
-1,693\end{array}$ & $\begin{array}{r}-18.9 \\
-42.3 \\
-9.6\end{array}$ & $\begin{array}{r}3,598 \\
-196 \\
-2,880\end{array}$ & $\begin{array}{r}355.5 \\
-91.6 \\
-19.2\end{array}$ & $\begin{array}{r}111 \\
-510 \\
1,071\end{array}$ & $\begin{array}{r}-100.0 \\
84.7\end{array}$ & $\begin{array}{l}60 \\
61 \\
62\end{array}$ \\
\hline
\end{tabular}


Table 37.-Value of Land and Butldings of Farms Operated by

[A minus sign (-)

\begin{tabular}{|c|c|c|c|c|c|c|c|}
\hline & \multirow{3}{*}{$\begin{array}{c}\text { SECTION, DIVISION, } \\
\text { AND STATE }\end{array}$} & \multicolumn{6}{|c|}{ VALUE OF LAND AND BUTLDINGS } \\
\hline & & \multicolumn{2}{|c|}{ Total } & \multicolumn{2}{|c|}{ Owners } & \multicolumn{2}{|c|}{ Tenants } \\
\hline & & 1930 & 1920 & 1930 & 1920 & 1930 & 1920 \\
\hline 1 & Onited States_. & $\$ 1,402,945,799$ & $\$ 2,257,645,325$ & $\$ 384,451,996$ & $\$ 554,158,008$ & $\$ 1,058,649,638$ & $\$ 1,676,315,864$ \\
\hline $\begin{array}{l}2 \\
3 \\
4\end{array}$ & $\begin{array}{l}\text { The North-- } \\
\text { The South--- } \\
\text { The West..- }\end{array}$ & $\begin{array}{r}41,668,222 \\
1,355,181,667 \\
6,095.910 \\
\end{array}$ & $\begin{array}{r}59,832,464 \\
2,191,005,642 \\
6,807,219 \\
\end{array}$ & $\begin{array}{r}17,684,979 \\
314,100,432 \\
2,665,985 \\
\end{array}$ & $\begin{array}{r}28,481,761 \\
522,178,137 \\
3,498,105 \\
\end{array}$ & $\begin{array}{r}22,327,483 \\
1,028,371,428 \\
2,950,725 \\
\end{array}$ & $\begin{array}{r}26,258,443 \\
1,647,447,607 \\
2,609,814 \\
\end{array}$ \\
\hline 5 & New England... & 909,395 & $1,076,815$ & $65 \overline{1,325}$ & 617,165 & $=67,070$ & 234,750 \\
\hline $\begin{array}{r}6 \\
7 \\
8 \\
9 \\
10 \\
11\end{array}$ & $\begin{array}{l}\text { Maine } \\
\text { N. Hampshire. } \\
\text { Vermont..... } \\
\text { Massachusetts. } \\
\text { Rhode Island.- } \\
\text { Connecticut..-- }\end{array}$ & $\begin{array}{r}41,400 \\
18,000 \\
118,700 \\
376,595 \\
40,000 \\
314,700\end{array}$ & \begin{tabular}{r|}
54,400 \\
29,400 \\
116,725 \\
345,800 \\
31,500 \\
498,990
\end{tabular} & $\begin{array}{r}28,400 \\
18,000 \\
85,700 \\
342,525 \\
32,000 \\
146,710\end{array}$ & $\begin{array}{r}54,400 \\
18,200 \\
87,125 \\
243,350 \\
16,900 \\
197,190\end{array}$ & $\begin{array}{r}13,000 \\
2,000 \\
8,000 \\
11,070 \\
33,000\end{array}$ & $\begin{array}{r}1,200 \\
20,700 \\
20,450 \\
7,600 \\
184,800\end{array}$ \\
\hline 12 & Mid. Atlantic.... & $5,140,255$ & $6,937,600$ & $2,422,675$ & $2,294,225$ & $2,165,880$ & $2,854,710$ \\
\hline $\begin{array}{l}13 \\
14 \\
15\end{array}$ & $\begin{array}{l}\text { New York...- } \\
\text { New Jersey } \\
\text { Pennsylvania. }\end{array}$ & $\begin{array}{r}875,575 \\
2,070,400 \\
2,194,280\end{array}$ & $\begin{array}{l}1,558,950 \\
2,117,590 \\
3,261,060\end{array}$ & $\begin{array}{l}548,095 \\
998,500 \\
876,080\end{array}$ & $\begin{array}{l}619,600 \\
755,715 \\
918,910\end{array}$ & $\begin{array}{r}230,980 \\
755,400 \\
1,179,500\end{array}$ & $\begin{array}{r}483,710 \\
1,107,375 \\
1,263,625\end{array}$ \\
\hline 16 & E. N. Central... & $13,304,751$ & $22,308,742$ & $6,796,536$ & $10,433,924$ & $6,092,645$ & $10,528,018$ \\
\hline $\begin{array}{l}17 \\
18 \\
19 \\
20 \\
21\end{array}$ & $\begin{array}{l}\text { Ohio } \\
\text { Indiana } \\
\text { Illinois } \\
\text { Michigan } \\
\text { Wisconsin... }\end{array}$ & $\begin{array}{r}\mathbf{5}, \mathbf{4 3 4}, \mathbf{7 3 5} \\
\mathbf{1}, \mathbf{9 4 7 , 9 1 5} \\
\mathbf{3}, \mathbf{7 0 4 , 6 1 8} \\
\mathbf{1}, \mathbf{8 7 4}, \mathbf{3 7 8} \\
\mathbf{3 4 3}, \mathbf{1 0 5}\end{array}$ & $\begin{array}{r}9,126,482 \\
4,254,030 \\
6,082,675 \\
2,566,855 \\
278,700\end{array}$ & $\begin{array}{r}2,641,920 \\
949,485 \\
1,562,898 \\
1,401,728 \\
240,505\end{array}$ & $\begin{array}{r}4,173,124 \\
1,831,910 \\
2,541,000 \\
1,643,890 \\
244,000\end{array}$ & $\begin{array}{r}2,649,595 \\
975,555 \\
1,972,745 \\
392,150 \\
102,600\end{array}$ & $\begin{array}{r}4,215,998 \\
2,157,980 \\
3,297,075 \\
822,265 \\
34,700\end{array}$ \\
\hline 22 & W. N. Central_-_ & $22,313,821$ & $29,509,307$ & $7,814,443$ & $15,136,447$ & $14,001,888$ & $12,640,965$ \\
\hline $\begin{array}{l}23 \\
24 \\
25 \\
26 \\
27 \\
28 \\
29\end{array}$ & $\begin{array}{l}\text { Minnesota.-... } \\
\text { Iowa } \\
\text { Missouri } \\
\text { North Dakota. } \\
\text { South Dakota } \\
\text { Nebraska...... } \\
\text { Kansas....... }\end{array}$ & $\begin{array}{r}187,325 \\
878,234 \\
14,498,297 \\
62,700 \\
285,425 \\
308,080 \\
6,093,760\end{array}$ & \begin{tabular}{r|}
134,670 \\
$1,330,600$ \\
$16,524,007$ \\
285,740 \\
623,515 \\
$1,095,040$ \\
$9,515,735$
\end{tabular} & $\begin{array}{r}141,675 \\
350,814 \\
3,429,544 \\
40,700 \\
163,295 \\
149,530 \\
3,538,885\end{array}$ & $\begin{array}{r}75,320 \\
683,250 \\
8,449,937 \\
85,140 \\
357,315 \\
445,540 \\
5,039,945\end{array}$ & $\begin{array}{r}45,650 \\
527,420 \\
10,706,493 \\
22,000 \\
101,730 \\
158,550 \\
2,440,045\end{array}$ & $\begin{array}{r}59,350 \\
596,350 \\
6,797,975 \\
177,600 \\
242,200 \\
549,500 \\
4,217,990\end{array}$ \\
\hline 30 & S. Atlantic....... & $484,443,943$ & $981,677,765$ & $135,724,157$ & $237,088,264$ & $341,922,425$ & $733,440,819$ \\
\hline $\begin{array}{l}31 \\
32 \\
33 \\
34 \\
35 \\
36 \\
37 \\
38 \\
39\end{array}$ & $\begin{array}{l}\text { Delaware } \\
\text { Maryland...... } \\
\text { Dist. Columbia } \\
\text { Virginia.....- } \\
\text { West Virginla. } \\
\text { N. Carolina.-. } \\
\text { S. Carolina.... } \\
\text { Georgia } \\
\text { Florida. }\end{array}$ & $\begin{array}{r}2,628,590 \\
18,896,282 \\
82,000 \\
71,722,401 \\
1,480,628 \\
153,882,635 \\
105,693,220 \\
114,688,230 \\
15,369,957\end{array}$ & $\begin{array}{r}2,885,445 \\
21,651,121 \\
233,300 \\
100,839,641 \\
1,727,890 \\
223,666,166 \\
290,406,115 \\
322,706,709 \\
17,561,378\end{array}$ & \begin{tabular}{|r|}
804,240 \\
$6,695,319$ \\
43,100 \\
$41,743,427$ \\
832,553 \\
$36,881,352$ \\
$22,788,137$ \\
$17,528,122$ \\
$8,407,507$ \\
\end{tabular} & \begin{tabular}{|r|}
681,300 \\
$7,959,597$ \\
40,300 \\
$57,004,473$ \\
956,562 \\
$56,113,060$ \\
$59,839,583$ \\
$45,465,436$ \\
$9,027,953$
\end{tabular} & $\begin{array}{r}1,509,675 \\
10,442,663 \\
8,500 \\
28,629,746 \\
415,575 \\
116,568,229 \\
82,319,129 \\
96,253,338 \\
5,775,570\end{array}$ & $\begin{array}{r}2,060,495 \\
11,354,874 \\
87,300 \\
41,502,119 \\
547,628 \\
166,525,511 \\
228,355,704 \\
275,484,273 \\
7,522,915\end{array}$ \\
\hline 40 & E. S. Central.... & $426,528,844$ & $645,828,371$ & $82,453,066$ & $127,401,052$ & $340,962,633$ & $513,777,358$ \\
\hline $\begin{array}{l}41 \\
42 \\
43 \\
44\end{array}$ & $\begin{array}{l}\text { Kentucky....- } \\
\text { Tennessee.... } \\
\text { Alabama..... } \\
\text { Mississippi.... }\end{array}$ & $\begin{array}{r}16,157,593 \\
56,339,610 \\
104,726,209 \\
249,305,432\end{array}$ & \begin{tabular}{r|}
$36,067,878$ \\
$90,427,645$ \\
$116,894,012$ \\
$402,438,836$
\end{tabular} & $\begin{array}{r}7,348,683 \\
14,169 ; 523 \\
24,945,906 \\
35,988,954\end{array}$ & $\begin{array}{l}16,389,797 \\
25,276,745 \\
29,021,680 \\
56,712,830\end{array}$ & $\begin{array}{r}8,430,710 \\
41,395,987 \\
79,029,593 \\
212,106,343\end{array}$ & $\begin{array}{r}18,993,535 \\
64,349,200 \\
86,821,727 \\
343,612,896\end{array}$ \\
\hline 45 & W. S. Central... & $444,208,880$ & $563,499,506$ & $95,923,219$ & $157,688,821$ & $345,486,370$ & $400,229,430$ \\
\hline $\begin{array}{l}46 \\
47 \\
48 \\
49\end{array}$ & $\begin{array}{l}\text { Arkansas. } \\
\text { Louisiana........ } \\
\text { Oklahoma..... } \\
\text { Texas_-_. }\end{array}$ & $\begin{array}{r}118,180,961 \\
108,668,818 \\
37,967,113 \\
179,391,988\end{array}$ & \begin{tabular}{r|}
$182,378,759$ \\
$107,615,718$ \\
$48,640,707$ \\
$224,864,322$
\end{tabular} & $\begin{array}{r}21,790,174 \\
19,567,276 \\
9,954,907 \\
44,610,852\end{array}$ & \begin{tabular}{|l|}
$45,536,138$ \\
$25,438,223$ \\
$19,227,142$ \\
$67,487,318$
\end{tabular} & $\begin{array}{r}96,062,087 \\
88,375,116 \\
27,725,473 \\
133,323,694\end{array}$ & $\begin{array}{r}135,655,066 \\
81,324,185 \\
28,681,300 \\
154,568,879\end{array}$ \\
\hline 50 & Mountain......... & $2,037,510$ & $2,523,814$ & 943,685 & $1,273,200$ & $1,012,825$ & 916,214 \\
\hline $\begin{array}{l}51 \\
52 \\
53 \\
54 \\
55 \\
56 \\
57 \\
58\end{array}$ & $\begin{array}{l}\text { Montana..... } \\
\text { Idaho } \\
\text { Wyoming } \\
\text { Colorado... } \\
\text { New Mexico... } \\
\text { Arizona } \\
\text { Utah } \\
\text { Nevada. }\end{array}$ & $\begin{array}{r}115,084 \\
107,200 \\
139,020 \\
445,540 \\
400,956 \\
761,510 \\
24,200 \\
44,000\end{array}$ & $\begin{array}{r}240,310 \\
134,900 \\
131,410 \\
944,405 \\
124,894 \\
277,700 \\
651,045 \\
19,150\end{array}$ & $\begin{array}{r}84,084 \\
41,700 \\
119,660 \\
263,910 \\
182,881 \\
195,250 \\
20,200 \\
36,000\end{array}$ & $\begin{array}{r}197,350 \\
83,200 \\
131,410 \\
544,115 \\
88,380 \\
117,500 \\
94,245 \\
17,000\end{array}$ & $\begin{array}{r}31,000 \\
47,500 \\
19,360 \\
178,430 \\
218,075 \\
506,460 \\
4,000 \\
8,000\end{array}$ & $\begin{array}{r}223,090 \\
36,514 \\
86,200 \\
476,800 \\
2,150\end{array}$ \\
\hline 59 & Pacific_.......... & $4,058,400$ & $4,283,405$ & $1,722,300$ & $2,224,905$ & $1,937,900$ & $1,693,600$ \\
\hline $\begin{array}{l}60 \\
61 \\
62\end{array}$ & $\begin{array}{l}\text { Washington... } \\
\text { Oregon } \\
\text { California.-. }\end{array}$ & $\begin{array}{r}356,705 \\
32,420 \\
3,669,275\end{array}$ & $\begin{array}{r}538,480 \\
119,400 \\
3,625,525\end{array}$ & $\begin{array}{r}268,155 \\
26,420 \\
1,427,725\end{array}$ & $\begin{array}{r}378,960 \\
57,400 \\
1,788,545\end{array}$ & $\begin{array}{r}77,950 \\
6,000 \\
1,853,950\end{array}$ & $\begin{array}{r}159,520 \\
18,000 \\
1,516,080\end{array}$ \\
\hline
\end{tabular}


Negroes, by Tenure, by Sections, Divisions, and States: 1930 and 1920 denotes decrease]

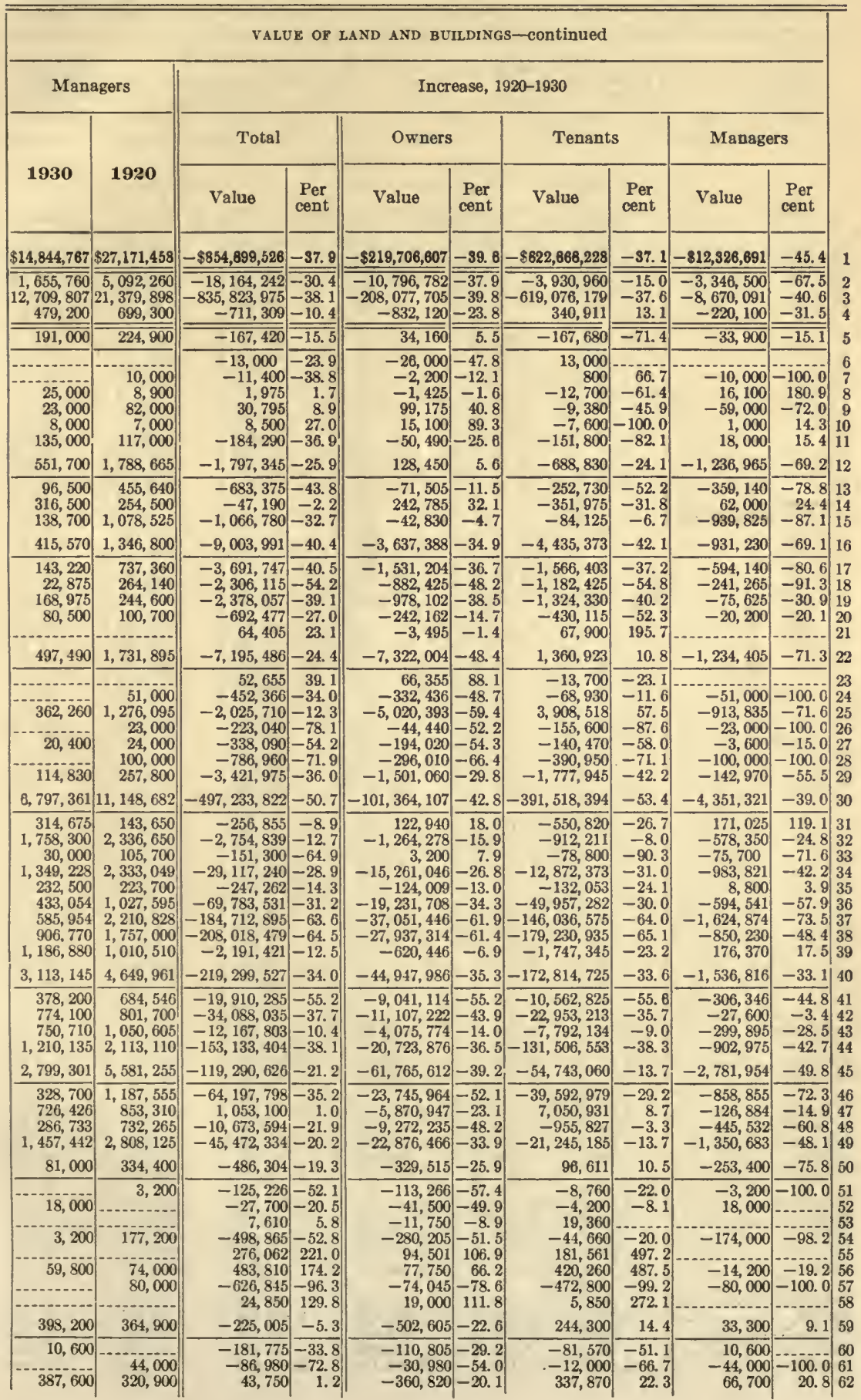


Table 38.-Farms Operated by Negroes-Number, Acreage, and Valde of Specified Classes of Farm Property, by States and Codnties, 1930

[Counties for whlch less than five Negro farm operators were reported are included with "Other counties"]

\begin{tabular}{|c|c|c|c|c|c|c|}
\hline \multirow{2}{*}{ STATE AND COUNTY } & \multirow{2}{*}{$\begin{array}{l}\text { Number } \\
\text { of farms }\end{array}$} & \multirow{2}{*}{$\begin{array}{l}\text { Land in } \\
\text { farms } \\
\text { (acres) }\end{array}$} & \multicolumn{3}{|c|}{ VALUE OF LAND AND BUIIDINGS } & \multirow{2}{*}{$\begin{array}{l}\text { Value of } \\
\text { imple- } \\
\text { ments and } \\
\text { machinery }\end{array}$} \\
\hline & & & Total & Land alone & Buildings & \\
\hline & \multicolumn{6}{|c|}{ ALABAMA } \\
\hline Tota & 93,795 & $4,157,051$ & $\$ 104,726,209$ & $\$ 77,521,909$ & $\$ 27,204,300$ & $\$ 5,091,581$ \\
\hline $\begin{array}{l}\text { Autauga } \\
\text { Baldwin. } \\
\text { Barbour } \\
\text { Bibb } \\
\text { Blount }\end{array}$ & $\begin{array}{r}1,924 \\
320 \\
2,262 \\
668 \\
86\end{array}$ & $\begin{array}{r}77,169 \\
9,661 \\
155,085 \\
24,606 \\
4,115\end{array}$ & $\begin{array}{r}1,763,200 \\
280,150 \\
2,398,743 \\
703,095 \\
105,860\end{array}$ & $\begin{array}{r}1,282,270 \\
192,630 \\
1,604,377 \\
525,140 \\
70,725\end{array}$ & $\begin{array}{r}480,930 \\
87,520 \\
794,366 \\
177,955 \\
35,135\end{array}$ & $\begin{array}{r}84,461 \\
15,483 \\
110,646 \\
31,720 \\
6,349\end{array}$ \\
\hline $\begin{array}{l}\text { Bullock } \\
\text { Butler } \\
\text { Calhoun } \\
\text { Chambers } \\
\text { Cherokee. }\end{array}$ & $\begin{array}{r}2,473 \\
1,695 \\
461 \\
2,431 \\
274\end{array}$ & $\begin{array}{r}131,304 \\
82,713 \\
21,864 \\
145,408 \\
15,179\end{array}$ & $\begin{array}{r}1,980,007 \\
1,822,222 \\
633,055 \\
2,810,492 \\
511,077\end{array}$ & $\begin{array}{r}1,285,947 \\
1,286,131 \\
459,969 \\
1,960,380 \\
421,679\end{array}$ & $\begin{array}{r}694,060 \\
536,091 \\
173,086 \\
850,112 \\
89,398\end{array}$ & $\begin{array}{r}134,411 \\
74,207 \\
28,512 \\
103,711 \\
31,766\end{array}$ \\
\hline $\begin{array}{l}\text { Chilton } \\
\text { Choctaw } \\
\text { Clarke- } \\
\text { Clay } \\
\text { Cleburne }\end{array}$ & $\begin{array}{r}575 \\
1,611 \\
1,772 \\
359 \\
67\end{array}$ & $\begin{array}{r}28,250 \\
79,538 \\
82,377 \\
19,391 \\
3,175\end{array}$ & $\begin{array}{r}629,481 \\
1,382,777 \\
1,452,771 \\
383,554 \\
67,192\end{array}$ & $\begin{array}{r}458,536 \\
883,986 \\
1,007,386 \\
238,084 \\
49,682\end{array}$ & $\begin{array}{r}170,945 \\
498,791 \\
445,385 \\
145,470 \\
17,510\end{array}$ & $\begin{array}{r}27,215 \\
55,903 \\
57,909 \\
15,720 \\
4,133\end{array}$ \\
\hline $\begin{array}{l}\text { Coffee } \\
\text { Colbert. } \\
\text { Conecuh. } \\
\text { Coosa } \\
\text { Covington... }\end{array}$ & $\begin{array}{r}732 \\
931 \\
1,476 \\
677 \\
520\end{array}$ & $\begin{array}{l}43,997 \\
37,433 \\
66,149 \\
59,560 \\
25,032\end{array}$ & $\begin{array}{r}1,256,612 \\
2,752,667 \\
1,659,735 \\
666,912 \\
797,315\end{array}$ & $\begin{array}{r}978,217 \\
2,447,924 \\
1,046,575 \\
417,085 \\
537,750\end{array}$ & $\begin{array}{l}278,395 \\
304,743 \\
613,160 \\
249,827 \\
259,565\end{array}$ & $\begin{array}{l}37,067 \\
85,114 \\
71,196 \\
32,344 \\
40,210\end{array}$ \\
\hline $\begin{array}{l}\text { Crenshaw } \\
\text { Cullman } \\
\text { Dale } \\
\text { Dallas } \\
\text { De Kalb }\end{array}$ & $\begin{array}{r}1,030 \\
76 \\
515 \\
6,405 \\
58\end{array}$ & $\begin{array}{r}54,909 \\
4,575 \\
31,546 \\
210,683 \\
2,748\end{array}$ & $\begin{array}{r}1,526,495 \\
137,575 \\
919,210 \\
5,048,579 \\
102,430\end{array}$ & $\begin{array}{r}1,134,275 \\
104,130 \\
756,360 \\
3,470,624 \\
78,430\end{array}$ & $\begin{array}{r}392,220 \\
33,445 \\
162,850 \\
1,577,955 \\
24,000\end{array}$ & $\begin{array}{r}48,040 \\
5,550 \\
23,921 \\
335,482 \\
4,811\end{array}$ \\
\hline $\begin{array}{l}\text { Elmore } \\
\text { Escambia } \\
\text { Etowah } \\
\text { Fayette. } \\
\text { Franklin. }\end{array}$ & $\begin{array}{r}1,837 \\
404 \\
152 \\
327 \\
113\end{array}$ & $\begin{array}{r}76,502 \\
15,919 \\
6,602 \\
22,205 \\
5,495\end{array}$ & $\begin{array}{r}2,635,426 \\
680,920 \\
248,432 \\
337,670 \\
190,320\end{array}$ & $\begin{array}{r}1,950,520 \\
472,515 \\
190,857 \\
249,615 \\
138,995\end{array}$ & $\begin{array}{r}684,906 \\
208,405 \\
57,575 \\
88,055 \\
51,325\end{array}$ & $\begin{array}{l}75,609 \\
25,260 \\
13,435 \\
20,493 \\
13,745\end{array}$ \\
\hline $\begin{array}{l}\text { Geneva } \\
\text { Greene } \\
\text { Hale... } \\
\text { Henry } \\
\text { Houston }\end{array}$ & $\begin{array}{r}302 \\
3,168 \\
3,873 \\
1,331 \\
971\end{array}$ & $\begin{array}{r}16,889 \\
121,010 \\
128,902 \\
84,132 \\
49,275\end{array}$ & $\begin{array}{r}687,926 \\
2,557,493 \\
4,363,062 \\
2,394,010 \\
2,177,345\end{array}$ & $\begin{array}{r}571,591 \\
1,912,930 \\
3,415,927 \\
1,903,030 \\
1,767,810\end{array}$ & $\begin{array}{l}116,335 \\
644,563 \\
947,135 \\
490,980 \\
409,535\end{array}$ & $\begin{array}{r}17,321 \\
126,117 \\
249,260 \\
83,329 \\
77,246\end{array}$ \\
\hline $\begin{array}{l}\text { Jackson } \\
\text { Jefferson } \\
\text { Lamar } \\
\text { Lauderdale... } \\
\text { Lawrence.... }\end{array}$ & $\begin{array}{r}281 \\
327 \\
410 \\
959 \\
1,393\end{array}$ & $\begin{array}{r}12,265 \\
8,823 \\
32,371 \\
39,046 \\
52,458\end{array}$ & $\begin{array}{r}530,730 \\
1,082,505 \\
427,502 \\
2,034,431 \\
2,463,289\end{array}$ & $\begin{array}{r}424,745 \\
911,090 \\
304,247 \\
1,650,804 \\
2,056,784\end{array}$ & $\begin{array}{l}105,985 \\
171,415 \\
123,255 \\
383,627 \\
406,505\end{array}$ & $\begin{array}{r}21,514 \\
16,699 \\
31,017 \\
113,898 \\
98,778\end{array}$ \\
\hline $\begin{array}{l}\text { Limestone } \\
\text { Lowndes. } \\
\text { Macon } \\
\text { Madison }\end{array}$ & $\begin{array}{l}1,992 \\
1,929 \\
3,527 \\
3,114 \\
2,772\end{array}$ & $\begin{array}{r}138,258 \\
65,315 \\
124,653 \\
145,173 \\
106,212\end{array}$ & $\begin{array}{l}2,377,692 \\
2,979,006 \\
2,923,121 \\
3,417,057 \\
4,345,764\end{array}$ & $\begin{array}{l}1,636,312 \\
2,459,830 \\
2,034,590 \\
2,385,340 \\
3,552,389\end{array}$ & $\begin{array}{r}741,380 \\
519,176 \\
888,531 \\
1,031,717 \\
793,375\end{array}$ & $\begin{array}{l}106,634 \\
153,918 \\
188,567 \\
203,260 \\
193,445\end{array}$ \\
\hline $\begin{array}{l}\text { Marengo } \\
\text { Marion } \\
\text { Marshail } \\
\text { Mobile. } \\
\text { Monroe.... }\end{array}$ & $\begin{array}{r}5,314 \\
70 \\
102 \\
149 \\
2,091\end{array}$ & $\begin{array}{r}158,890 \\
5,439 \\
3,764 \\
5,224 \\
93,129\end{array}$ & $\begin{array}{r}3,918,964 \\
65,735 \\
151,670 \\
268,247 \\
1,951,440\end{array}$ & $\begin{array}{r}2,791,210 \\
42,745 \\
131,262 \\
197,650 \\
1,285,809\end{array}$ & $\begin{array}{r}1,127,754 \\
22,990 \\
20,408 \\
70,597 \\
665,631\end{array}$ & $\begin{array}{r}272,583 \\
4,422 \\
6,108 \\
11,546 \\
118,304\end{array}$ \\
\hline $\begin{array}{l}\text { Montgomery-... } \\
\text { Morgan } \\
\text { Perry } \\
\text { Pickens } \\
\text { Pike........ }\end{array}$ & $\begin{array}{l}3,178 \\
659 \\
3,435 \\
2,119 \\
1,506\end{array}$ & $\begin{array}{r}120,675 \\
23,452 \\
128,949 \\
103,188 \\
90,462\end{array}$ & $\begin{array}{l}4,056,209 \\
1,225,220 \\
2,976,587 \\
2,096,577 \\
2,164,001\end{array}$ & $\begin{array}{l}3,096,339 \\
1,005,380 \\
2,349,690 \\
1,403,036 \\
1,668,776\end{array}$ & $\begin{array}{l}959,870 \\
219,840 \\
626,897 \\
693,541 \\
495,225\end{array}$ & $\begin{array}{r}157,403 \\
69,399 \\
152,797 \\
105,753 \\
63,859\end{array}$ \\
\hline $\begin{array}{l}\text { Randolph. } \\
\text { Russell } \\
\text { St. Clair... } \\
\text { Shelby } \\
\text { Sumter... }\end{array}$ & $\begin{array}{r}791 \\
2,243 \\
348 \\
392 \\
3,812\end{array}$ & $\begin{array}{r}45,800 \\
135,972 \\
23,201 \\
16,802 \\
150,050\end{array}$ & $\begin{array}{r}819,633 \\
2,037,429 \\
542,080 \\
456,065 \\
3,180,102\end{array}$ & $\begin{array}{r}554,803 \\
1,452,191 \\
418,525 \\
282,495 \\
2,307,911\end{array}$ & $\begin{array}{l}264,830 \\
585,238 \\
123,555 \\
173,570 \\
872,191\end{array}$ & $\begin{array}{r}37,498 \\
123,278 \\
27,136 \\
25,532 \\
203,069\end{array}$ \\
\hline
\end{tabular}


Table 38.-Farms Operated by Negroes-Number, Acreage, and Value of Specified Classes of Farm Property, by States and Counties, 1930Continued

\begin{tabular}{|c|c|c|c|c|c|c|}
\hline \multirow{2}{*}{ STATE AND COUNTY } & \multirow{2}{*}{$\begin{array}{l}\text { Number } \\
\text { of farms }\end{array}$} & \multirow{2}{*}{$\begin{array}{l}\text { Land in } \\
\text { farms } \\
\text { (acres) }\end{array}$} & \multicolumn{3}{|c|}{ VALUE OF LAND AND BUILDINGS } & \multirow{2}{*}{$\begin{array}{l}\text { Value of } \\
\text { imple- } \\
\text { ments and } \\
\text { machinery }\end{array}$} \\
\hline & & & Total & Land alone & Buildings & \\
\hline \multirow{3}{*}{$\begin{array}{l}\text { Talladega } \\
\text { Tallapoosa } \\
\text { Tuscaloosa } \\
\text { Walker... } \\
\text { Washington } \\
\text { Wilcox }\end{array}$} & \multicolumn{6}{|c|}{ ALABAMA -continued } \\
\hline & $\begin{array}{r}1,912 \\
1,161 \\
1,545 \\
92 \\
676 \\
3,620\end{array}$ & $\begin{array}{r}102,239 \\
74,812 \\
69,635 \\
2,557 \\
32,126 \\
102,713\end{array}$ & $\begin{array}{r}\$ 2,346,943 \\
1,432,890 \\
1,904,740 \\
63,020 \\
523,834 \\
1,899,916\end{array}$ & $\begin{array}{r}\$ 1,700,858 \\
987,647 \\
1,525,087 \\
42,305 \\
350,993 \\
1,238,984\end{array}$ & $\begin{array}{r}\$ 646,085 \\
445,243 \\
379,653 \\
20,715 \\
172,841 \\
660,932\end{array}$ & $\begin{array}{r}\$ 125,346 \\
62,264 \\
57,748 \\
2,956 \\
30,398 \\
138,756\end{array}$ \\
\hline & \multicolumn{6}{|c|}{$\triangle$ ARIZONA } \\
\hline Total. & 87 & 7,786 & $\$ 761,510$ & $\$ 698,930$ & $\$ 62,580$ & $\$ 32,175$ \\
\hline \multirow[t]{2}{*}{$\begin{array}{l}\text { Graham } \\
\text { Maricopa. } \\
\text { Yuma } \\
\text { Other counties..... }\end{array}$} & $\begin{array}{r}5 \\
51 \\
16 \\
15\end{array}$ & $\begin{array}{r}600 \\
2,709 \\
1,580 \\
2,877\end{array}$ & $\begin{array}{r}13,000 \\
552,010 \\
159,900 \\
36,600\end{array}$ & $\begin{array}{r}11,585 \\
515,475 \\
146,000 \\
25,890\end{array}$ & $\begin{array}{r}1,435 \\
36,535 \\
13,900 \\
10,710\end{array}$ & $\begin{array}{r}715 \\
19,025 \\
8,250 \\
4,185\end{array}$ \\
\hline & \multicolumn{6}{|c|}{ ARKANSAS } \\
\hline Total. & 79,556 & $2,485,626$ & $\$ 118,180,961$ & $\$ 94,312,157$ & $\$ 23,868,804$ & $\$ 4,769,958$ \\
\hline $\begin{array}{l}\text { Arkansas........ } \\
\text { Ashley } \\
\text { Bradley } \\
\text { Calhoun............... } \\
\text { Chicot.......... }\end{array}$ & $\begin{array}{r}605 \\
2,189 \\
606 \\
444 \\
3,036\end{array}$ & $\begin{array}{l}29,289 \\
60,827 \\
28,302 \\
27,030 \\
71,870\end{array}$ & $\begin{array}{r}611,710 \\
3,106,415 \\
610,324 \\
505,370 \\
4,419,538\end{array}$ & $\begin{array}{r}458,879 \\
2,500,212 \\
421,688 \\
401,532 \\
3,365,065\end{array}$ & $\begin{array}{r}152,831 \\
606,203 \\
188,636 \\
103,838 \\
1,084,473\end{array}$ & $\begin{array}{r}44,250 \\
161,457 \\
31,539 \\
22,906 \\
227,909\end{array}$ \\
\hline $\begin{array}{l}\text { Clark } \\
\text { Cleveland } \\
\text { Columbia- } \\
\text { Conway } \\
\text { Craighead }\end{array}$ & $\begin{array}{r}835 \\
656 \\
2,374 \\
964 \\
68\end{array}$ & $\begin{array}{r}39,865 \\
31,065 \\
118,641 \\
52,035 \\
2,242\end{array}$ & $\begin{array}{r}992,096 \\
524,600 \\
3,160,206 \\
1,401,760 \\
162,885\end{array}$ & $\begin{array}{r}811,319 \\
350,950 \\
2,420,997 \\
1,081,616 \\
140,202\end{array}$ & $\begin{array}{r}180,777 \\
173,650 \\
739,209 \\
320,144 \\
22,683\end{array}$ & $\begin{array}{r}41,561 \\
31,126 \\
132,908 \\
50,143 \\
5,650\end{array}$ \\
\hline $\begin{array}{l}\text { Crawford } \\
\text { Crittenden } \\
\text { Cross } \\
\text { Dallas } \\
\text { Desha }\end{array}$ & $\begin{array}{r}54 \\
7,003 \\
2,416 \\
452 \\
2,843\end{array}$ & $\begin{array}{r}2,966 \\
162,067 \\
62,344 \\
24,280 \\
67,542\end{array}$ & $\begin{array}{r}89,250 \\
12,038,354 \\
4,446,282 \\
452,725 \\
3,491,636\end{array}$ & $\begin{array}{r}68,145 \\
9,789,480 \\
3,683,670 \\
323,860 \\
2,669,410\end{array}$ & $\begin{array}{r}21,105 \\
2,248,874 \\
762,612 \\
128,865 \\
822,226\end{array}$ & $\begin{array}{r}3,025 \\
332,587 \\
182,639 \\
22,244 \\
255,786\end{array}$ \\
\hline $\begin{array}{l}\text { Drew } \\
\text { Faulkner } \\
\text { Franklin } \\
\text { Garland } \\
\text { Grant }\end{array}$ & $\begin{array}{r}1,876 \\
483 \\
33 \\
21 \\
115\end{array}$ & $\begin{array}{r}67,674 \\
25,633 \\
1,827 \\
1,067 \\
7,971\end{array}$ & $\begin{array}{r}2,282,423 \\
736,300 \\
62,850 \\
31,850 \\
115,250\end{array}$ & $\begin{array}{r}1,669,668 \\
578,365 \\
47,250 \\
24,505 \\
91,196\end{array}$ & $\begin{array}{r}612,755 \\
157,935 \\
15,600 \\
7,345 \\
24,054\end{array}$ & $\begin{array}{r}112,158 \\
30,154 \\
1,060 \\
617 \\
4,291\end{array}$ \\
\hline $\begin{array}{l}\text { Hempstead }-. . \\
\text { Hot Spring.-. } \\
\text { Howard.-....-. } \\
\text { Independence. } \\
\text { Izard........... }\end{array}$ & $\begin{array}{r}2,212 \\
62 \\
745 \\
52 \\
33\end{array}$ & $\begin{array}{r}93,393 \\
2,081 \\
22,879 \\
2,173 \\
1,951\end{array}$ & $\begin{array}{r}2,466,348 \\
100,100 \\
929,000 \\
84,757 \\
30,550\end{array}$ & $\begin{array}{r}1,981,608 \\
60,050 \\
739,120 \\
66,737 \\
19,600\end{array}$ & $\begin{array}{r}484,740 \\
40,050 \\
189,880 \\
18,020 \\
11,050\end{array}$ & $\begin{array}{r}89,082 \\
5,355 \\
33,511 \\
3,560 \\
4,045\end{array}$ \\
\hline $\begin{array}{l}\text { Jackson } \\
\text { Jefferson } \\
\text { Lahnson } \\
\text { Lawrence }\end{array}$ & $\begin{array}{r}694 \\
6,739 \\
19 \\
1,554 \\
19\end{array}$ & $\begin{array}{r}27,275 \\
160,156 \\
526 \\
52,062 \\
823\end{array}$ & $\begin{array}{r}1,621,960 \\
9,606,268 \\
12,978 \\
2,176,897 \\
31,450\end{array}$ & $\begin{array}{r}1,311,100 \\
7,843,807 \\
9,778 \\
1,785,892 \\
25,730\end{array}$ & $\begin{array}{r}310,860 \\
1,762,461 \\
3,200 \\
391,005 \\
5,720\end{array}$ & $\begin{array}{r}85,034 \\
352,167 \\
180 \\
81,927 \\
953\end{array}$ \\
\hline $\begin{array}{l}\text { Lee } \\
\text { LincoIn } \\
\text { Little River } \\
\text { Logan } \\
\text { Lonoke. }\end{array}$ & $\begin{array}{r}4,134 \\
3,598 \\
1,298 \\
65 \\
2,382\end{array}$ & $\begin{array}{r}121,122 \\
84,332 \\
43,067 \\
2,626 \\
59,678\end{array}$ & $\begin{array}{r}5,773,548 \\
4,372,286 \\
1,581,660 \\
171,700 \\
3,569,851\end{array}$ & $\begin{array}{r}4,277,534 \\
3,525,336 \\
1,336,843 \\
150,175 \\
2,987,894\end{array}$ & $\begin{array}{r}1,496,014 \\
846,950 \\
244,817 \\
21,525 \\
581,957\end{array}$ & $\begin{array}{r}285,517 \\
220,975 \\
57,163 \\
2,892 \\
118,507\end{array}$ \\
\hline $\begin{array}{l}\text { Miller } \\
\text { Mississippi } \\
\text { Monroe... } \\
\text { Montgomery } \\
\text { Nevada }\end{array}$ & $\begin{array}{r}1,407 \\
5,089 \\
2,272 \\
26 \\
1,117\end{array}$ & $\begin{array}{r}41,181 \\
111,614 \\
72,779 \\
1,780 \\
63,467\end{array}$ & $\begin{array}{r}2,338,470 \\
10,445,541 \\
3,611,123 \\
27,950 \\
1,180,920\end{array}$ & $\begin{array}{r}1,913,980 \\
8,889,504 \\
2,830,635 \\
18,750 \\
913,225\end{array}$ & $\begin{array}{r}424,490 \\
1,556,037 \\
780,488 \\
9,200 \\
267,695\end{array}$ & $\begin{array}{r}104,441 \\
194,913 \\
170,476 \\
875 \\
55,242\end{array}$ \\
\hline
\end{tabular}


Table 38.-Farms Operated by Negroes-Number, Acreage, and Value of Specified Classes of Farm Property, by States and Counties, 1930Continued

\begin{tabular}{|c|c|c|c|c|c|c|}
\hline \multirow{2}{*}{ STATE AND COUNTY } & \multirow{2}{*}{$\begin{array}{l}\text { Number } \\
\text { of farms }\end{array}$} & \multirow{2}{*}{$\begin{array}{l}\text { Land in } \\
\text { farms } \\
\text { (acres) }\end{array}$} & \multicolumn{3}{|c|}{ VALUE OF LAND AND BUILDINGS } & \multirow{2}{*}{$\begin{array}{l}\text { Value of } \\
\text { imple- } \\
\text { ments and } \\
\text { machinery }\end{array}$} \\
\hline & & & Total & Land alone & Buildings & \\
\hline & \multicolumn{6}{|c|}{ ARKANSAS-continued } \\
\hline $\begin{array}{l}\text { Ouachita } \\
\text { Perry } \\
\text { Philips } \\
\text { Pike_. } \\
\text { Poinsett.... }\end{array}$ & $\begin{array}{r}1,375 \\
85 \\
4,920 \\
115 \\
726\end{array}$ & $\begin{array}{r}86,670 \\
3,732 \\
128,693 \\
4,795 \\
17,705\end{array}$ & $\begin{array}{r}\$ 1,891,087 \\
120,600 \\
6,237,448 \\
144,630 \\
1,412,550\end{array}$ & $\begin{array}{r}\$ 1,399,825 \\
97,075 \\
5,035,244 \\
117,050 \\
1,233,574\end{array}$ & $\begin{array}{r}\$ 491,262 \\
23,525 \\
1,202,204 \\
27,580 \\
178,976\end{array}$ & $\begin{array}{r}\$ 94,966 \\
5,170 \\
267,828 \\
7,920 \\
54,137\end{array}$ \\
\hline $\begin{array}{l}\text { Pope } \\
\text { Prairie } \\
\text { Pulaski. } \\
\text { Randolph } \\
\text { St. Francis... }\end{array}$ & $\begin{array}{r}151 \\
511 \\
2,040 \\
35 \\
5,083\end{array}$ & $\begin{array}{r}6,482 \\
18,960 \\
54,109 \\
1,561 \\
142,473\end{array}$ & $\begin{array}{r}253,005 \\
645,195 \\
3,824,281 \\
80,880 \\
7,622,035\end{array}$ & $\begin{array}{r}199,015 \\
489,490 \\
3,183,821 \\
69,955 \\
5,740,512\end{array}$ & $\begin{array}{r}53,990 \\
155,705 \\
640,460 \\
10,925 \\
1,881,523\end{array}$ & $\begin{array}{r}7,847 \\
30,916 \\
146,377 \\
2,103 \\
250,699\end{array}$ \\
\hline $\begin{array}{l}\text { Saline } \\
\text { Sebastian } \\
\text { Sevier } \\
\text { Sharp } \\
\text { Union.... }\end{array}$ & $\begin{array}{r}32 \\
40 \\
247 \\
6 \\
1,493\end{array}$ & $\begin{array}{r}1,212 \\
1,437 \\
13,018 \\
457 \\
75,370\end{array}$ & $\begin{array}{r}46,140 \\
51,070 \\
312,615 \\
4,700 \\
2,027,262\end{array}$ & $\begin{array}{r}33,470 \\
41,870 \\
244,545 \\
3,800 \\
1,552,764\end{array}$ & $\begin{array}{r}12,670 \\
9,200 \\
68,070 \\
900 \\
474,498\end{array}$ & $\begin{array}{r}1,693 \\
1,255 \\
11,139 \\
250 \\
116,245\end{array}$ \\
\hline $\begin{array}{l}\text { Van Buren } \\
\text { Washington. } \\
\text { White } \\
\text { Woodruff } \\
\text { Yell } \\
\text { Other counties. }\end{array}$ & $\begin{array}{r}19 \\
16 \\
110 \\
1,831 \\
124 \\
7\end{array}$ & $\begin{array}{r}1,415 \\
562 \\
6,590 \\
64,657 \\
4,586 \\
1,010\end{array}$ & $\begin{array}{r}16,850 \\
15,710 \\
193,850 \\
3,657,912 \\
211,260 \\
6,700\end{array}$ & $\begin{array}{r}11,675 \\
12,950 \\
143,150 \\
2,944,285 \\
167,170 \\
5,710\end{array}$ & $\begin{array}{r}5,175 \\
2,760 \\
50,700 \\
713,627 \\
44,090 \\
990\end{array}$ & $\begin{array}{r}970 \\
1,282 \\
9,554 \\
193,031 \\
5,515 \\
234\end{array}$ \\
\hline Other counties..... & \multicolumn{6}{|c|}{ CALIFORNIA } \\
\hline Total & 424 & 30,297 & $83,689,275$ & $88,216,125$ & 8451,150 & $\$ 146, \$ 28$ \\
\hline $\begin{array}{l}\text { Fresno } \\
\text { Imperial } \\
\text { Kern } \\
\text { Kings } \\
\text { Los Angeles... }\end{array}$ & $\begin{array}{l}38 \\
80 \\
39 \\
11 \\
14\end{array}$ & $\begin{array}{r}1,234 \\
7,050 \\
2,029 \\
702 \\
407\end{array}$ & $\begin{array}{r}185,475 \\
729,760 \\
446,150 \\
91,500 \\
179,850\end{array}$ & $\begin{array}{r}153,975 \\
699,665 \\
417,150 \\
76,550 \\
166,500\end{array}$ & $\begin{array}{l}31,500 \\
30,095 \\
29,000 \\
14,950 \\
13,350\end{array}$ & $\begin{array}{r}7,510 \\
26,120 \\
16,155 \\
3,765 \\
3,625\end{array}$ \\
\hline $\begin{array}{l}\text { Madera } \\
\text { Merced. } \\
\text { Orange } \\
\text { Riverside } \\
\text { Sacramento... }\end{array}$ & $\begin{array}{l}17 \\
23 \\
15 \\
42 \\
11\end{array}$ & $\begin{array}{r}1,325 \\
1,118 \\
1,433 \\
1,899 \\
170\end{array}$ & $\begin{array}{r}150,400 \\
106,750 \\
120,100 \\
256,640 \\
51,200\end{array}$ & $\begin{array}{r}142,925 \\
85,790 \\
107,550 \\
233,495 \\
25,800\end{array}$ & $\begin{array}{r}7,475 \\
20,960 \\
12,550 \\
23,145 \\
25,400\end{array}$ & $\begin{array}{r}6,850 \\
6,230 \\
2,075 \\
19,850 \\
4,520\end{array}$ \\
\hline \multirow[t]{2}{*}{$\begin{array}{l}\text { San Bernardino } \\
\text { San Joaquin } \\
\text { Shasta. } \\
\text { Tulare } \\
\text { Yolo } \\
\text { Other counties. }\end{array}$} & $\begin{array}{r}22 \\
6 \\
9 \\
42 \\
4 \\
8 \\
47\end{array}$ & $\begin{array}{l}1,082 \\
2,848 \\
1,435 \\
2,890 \\
1,059 \\
3,616\end{array}$ & $\begin{array}{r}148,000 \\
197,300 \\
61,850 \\
421,300 \\
68,450 \\
454,550\end{array}$ & $\begin{array}{r}119,625 \\
188,400 \\
44,900 \\
366,200 \\
50,550 \\
339,050\end{array}$ & $\begin{array}{r}28,375 \\
8,900 \\
16,950 \\
55,100 \\
17,900 \\
115,500\end{array}$ & $\begin{array}{r}2,505 \\
4,200 \\
2,000 \\
13,335 \\
9,775 \\
17,811\end{array}$ \\
\hline & \multicolumn{6}{|c|}{ COLORADO } \\
\hline Total & 78 & 25,197 & $\$ 445,340$ & $\$ 371,890$ & 879,850 & 823,097 \\
\hline $\begin{array}{l}\text { Arapahoe } \\
\text { El Paso } \\
\text { Las Animas. } \\
\text { Otero } \\
\text { Washington }\end{array}$ & $\begin{array}{r}5 \\
5 \\
9 \\
13 \\
5\end{array}$ & $\begin{array}{l}2,646 \\
2,649 \\
2,125 \\
6,566 \\
1,200\end{array}$ & $\begin{array}{r}47,350 \\
36,880 \\
35,700 \\
99,380 \\
9,920\end{array}$ & $\begin{array}{r}42,850 \\
27,480 \\
26,550 \\
92,080 \\
8,520\end{array}$ & $\begin{array}{l}4,500 \\
9,400 \\
9,150 \\
7,300 \\
1,400\end{array}$ & $\begin{array}{r}2,300 \\
2,500 \\
1,160 \\
3,800 \\
567\end{array}$ \\
\hline \multirow[t]{2}{*}{$\begin{array}{l}\text { Weld } \\
\text { Otber counties }\end{array}$} & $\begin{array}{l}14 \\
27\end{array}$ & $\begin{array}{l}3,419 \\
6,532\end{array}$ & $\begin{array}{r}76,600 \\
139,710\end{array}$ & $\begin{array}{r}65,050 \\
109,360\end{array}$ & $\begin{array}{l}11,550 \\
30,350\end{array}$ & $\begin{array}{r}2,120 \\
10,650\end{array}$ \\
\hline & \multicolumn{6}{|c|}{ CONNECTICUT } \\
\hline Total $\ldots . . . . . . .$. & 39 & 1,919 & 8814,700 & $\$ 118,985$ & $\$ 188,995$ & 89,785 \\
\hline $\begin{array}{l}\text { Fairfield } \\
\text { Hartford } \\
\text { Other counties. }\end{array}$ & $\begin{array}{r}6 \\
9 \\
18\end{array}$ & $\begin{array}{l}187 \\
251 \\
881\end{array}$ & $\begin{array}{r}160,000 \\
65,300 \\
89,400\end{array}$ & $\begin{array}{l}50,000 \\
31,065 \\
35,300\end{array}$ & $\begin{array}{r}110,000 \\
34,235 \\
54,100\end{array}$ & $\begin{array}{l}2,300 \\
4,335 \\
3,100\end{array}$ \\
\hline
\end{tabular}


Table 38.-Farms Operated by Negroes-Number, Acreage, and Value of Specified Classes of Farm Property, by States and Counties, 1930 Continued

\begin{tabular}{|c|c|c|c|c|c|c|}
\hline \multirow{2}{*}{ STATE AND COUNTY } & \multirow{2}{*}{$\begin{array}{l}\text { Number } \\
\text { of farms }\end{array}$} & \multirow{2}{*}{$\begin{array}{l}\text { Land in } \\
\text { farms } \\
\text { (acres) }\end{array}$} & \multicolumn{3}{|c|}{ VALUE OF LAND AND BUILDINGS } & \multirow{2}{*}{$\begin{array}{l}\text { Value of } \\
\text { imple- } \\
\text { ments and } \\
\text { machinery }\end{array}$} \\
\hline & & & Total & Land alone & Buildings & \\
\hline \multirow{4}{*}{$\begin{array}{l}\text { Kent } \\
\text { New Castle. } \\
\text { Sussex }\end{array}$} & \multicolumn{6}{|c|}{ DELAWARE } \\
\hline & 807 & 54,758 & $82,628,590$ & $\$ 1,558,810$ & $81,074,780$ & 8224,010 \\
\hline & $\begin{array}{r}328 \\
75 \\
404\end{array}$ & $\begin{array}{r}23,294 \\
4,970 \\
26,492\end{array}$ & $\begin{array}{r}1,101,365 \\
404,925 \\
1,122,300\end{array}$ & $\begin{array}{l}702,955 \\
203,580 \\
647,275\end{array}$ & $\begin{array}{l}398,410 \\
201,345 \\
475,025\end{array}$ & $\begin{array}{r}87,040 \\
17,720 \\
119,250\end{array}$ \\
\hline & \multicolumn{6}{|c|}{ DISTRICT OY COLUMBIA } \\
\hline \multirow[t]{2}{*}{ Total. } & 11 & 95 & $\$ 82,000$ & 855,725 & $\$ 26,275$ & 81,225 \\
\hline & \multicolumn{6}{|c|}{ FLORIDA } \\
\hline Total & 11,010 & 518,912 & $815,369,957$ & $\$ 11,515,248$ & $88,854,714$ & 8687,528 \\
\hline $\begin{array}{l}\text { A lachua } \\
\text { Baker. } \\
\text { Bay } \\
\text { Bradford } \\
\text { Brevard }\end{array}$ & $\begin{array}{r}986 \\
36 \\
28 \\
161 \\
36\end{array}$ & $\begin{array}{r}45,665 \\
1,118 \\
676 \\
3,868 \\
703\end{array}$ & $\begin{array}{r}1,245,017 \\
34,950 \\
45,680 \\
199,650 \\
434,250\end{array}$ & $\begin{array}{r}812,092 \\
26,050 \\
29,655 \\
138,633 \\
405,080\end{array}$ & $\begin{array}{r}432,925 \\
8,900 \\
16,025 \\
61,017 \\
29,170\end{array}$ & $\begin{array}{r}57,686 \\
1,335 \\
2,330 \\
9,085 \\
4,215\end{array}$ \\
\hline $\begin{array}{l}\text { Broward } \\
\text { CaIhoun } \\
\text { Citrus. } \\
\text { Clay } \\
\text { Columbia. }\end{array}$ & $\begin{array}{r}403 \\
50 \\
18 \\
28 \\
427\end{array}$ & $\begin{array}{r}2,254 \\
2,351 \\
1,298 \\
1,137 \\
36,220\end{array}$ & $\begin{array}{r}234,130 \\
39,555 \\
22,850 \\
42,325 \\
523,265\end{array}$ & $\begin{array}{r}228,910 \\
28,425 \\
16,690 \\
31,010 \\
395,577\end{array}$ & $\begin{array}{r}5,220 \\
11,130 \\
6,160 \\
11,315 \\
127,688\end{array}$ & $\begin{array}{r}37,409 \\
1,383 \\
3,535 \\
2,315 \\
23,728\end{array}$ \\
\hline $\begin{array}{l}\text { Dade } \\
\text { Dixie-1e } \\
\text { Duval } \\
\text { Escambia } \\
\text { Gadsden } \\
\end{array}$ & $\begin{array}{r}69 \\
8 \\
128 \\
89 \\
639\end{array}$ & $\begin{array}{r}692 \\
196 \\
2,407 \\
2,576 \\
29,764\end{array}$ & $\begin{array}{r}115,525 \\
4,050 \\
236,840 \\
124,800 \\
738,090\end{array}$ & $\begin{array}{r}103,575 \\
2,250 \\
177,265 \\
87,745 \\
445,240\end{array}$ & $\begin{array}{r}11,950 \\
1,800 \\
59,575 \\
37,055 \\
292,850\end{array}$ & $\begin{array}{r}15,350 \\
205 \\
5,855 \\
5,293 \\
38,462\end{array}$ \\
\hline $\begin{array}{l}\text { Gilchrist } \\
\text { Gulf } \\
\text { Hamiliton. } \\
\text { Hendry } \\
\text { Hernando }\end{array}$ & $\begin{array}{r}7 \\
15 \\
220 \\
6 \\
88\end{array}$ & $\begin{array}{r}705 \\
579 \\
18,571 \\
99 \\
2,206\end{array}$ & $\begin{array}{r}12,740 \\
12,105 \\
255,816 \\
9,900 \\
239,075\end{array}$ & $\begin{array}{r}8,490 \\
8,525 \\
178,401 \\
9,850 \\
200,065\end{array}$ & $\begin{array}{r}4,250 \\
3,580 \\
77,415 \\
50 \\
39,010\end{array}$ & $\begin{array}{r}515 \\
800 \\
9,824 \\
300 \\
5,330\end{array}$ \\
\hline $\begin{array}{l}\text { Hillsborough } \\
\text { Holmes } \\
\text { Indian River. } \\
\text { Jackson } \\
\text { Jefferson }\end{array}$ & $\begin{array}{r}81 \\
21 \\
16 \\
1,566 \\
873\end{array}$ & $\begin{array}{r}1,771 \\
1,412 \\
245 \\
96,875 \\
38,778\end{array}$ & $\begin{array}{r}370,195 \\
27,220 \\
40,600 \\
1,781,425 \\
882,612\end{array}$ & $\begin{array}{r}313,320 \\
19,870 \\
37,100 \\
1,381,094 \\
614,549\end{array}$ & $\begin{array}{r}56,875 \\
7,350 \\
3,600 \\
400,331 \\
268,063\end{array}$ & $\begin{array}{r}8,310 \\
1,017 \\
350 \\
82,947 \\
40,751\end{array}$ \\
\hline $\begin{array}{l}\text { Lafayette. } \\
\text { Lake } \\
\text { Lee... } \\
\text { Leon } \\
\text { Levy. }\end{array}$ & $\begin{array}{r}7 \\
109 \\
9 \\
1,259 \\
188\end{array}$ & $\begin{array}{r}307 \\
2,449 \\
123 \\
52,349 \\
8,626\end{array}$ & $\begin{array}{r}6,600 \\
379,135 \\
16,300 \\
1,381,957 \\
153,976\end{array}$ & $\begin{array}{r}4,500 \\
313,920 \\
14,050 \\
1,067,206 \\
115,943\end{array}$ & $\begin{array}{r}2,100 \\
65,215 \\
2,250 \\
314,751 \\
38,033\end{array}$ & $\begin{array}{r}540 \\
6,780 \\
1,500 \\
56,729 \\
5,498\end{array}$ \\
\hline $\begin{array}{l}\text { Liberty } \\
\text { Madison } \\
\text { Manatee } \\
\text { Marion } \\
\text { Martin }\end{array}$ & $\begin{array}{r}72 \\
580 \\
24 \\
955 \\
23\end{array}$ & $\begin{array}{r}5,908 \\
35,611 \\
322 \\
35,238 \\
337\end{array}$ & $\begin{array}{r}77,925 \\
673,865 \\
149,200 \\
1,235,326 \\
47,340\end{array}$ & $\begin{array}{r}54,940 \\
448,805 \\
142,400 \\
868,729 \\
44,215\end{array}$ & $\begin{array}{r}22,985 \\
225,060 \\
6,800 \\
366,597 \\
3,125\end{array}$ & $\begin{array}{r}2,975 \\
34,840 \\
2,310 \\
75,384 \\
3,080\end{array}$ \\
\hline $\begin{array}{l}\text { Monroe } \\
\text { Nassau } \\
\text { Okaloosa. } \\
\text { Orange } \\
\text { Osceola }\end{array}$ & $\begin{array}{r}9 \\
43 \\
63 \\
56 \\
9\end{array}$ & $\begin{array}{r}907 \\
1,594 \\
3,412 \\
1,365 \\
92\end{array}$ & $\begin{array}{r}96,700 \\
46,900 \\
105,100 \\
479,895 \\
18,800\end{array}$ & $\begin{array}{r}86,800 \\
23,125 \\
82,595 \\
386,345 \\
14,550\end{array}$ & $\begin{array}{r}9,900 \\
23,775 \\
22,505 \\
93,550 \\
4,250\end{array}$ & $\begin{array}{r}100 \\
3,945 \\
3,030 \\
8,310 \\
900\end{array}$ \\
\hline $\begin{array}{l}\text { Palm Beach } \\
\text { Pasco } \\
\text { Polk } \\
\text { Putnam } \\
\text { St. Johns.... }\end{array}$ & $\begin{array}{r}177 \\
20 \\
42 \\
190 \\
33\end{array}$ & $\begin{array}{r}1,625 \\
361 \\
647 \\
5,903 \\
792\end{array}$ & $\begin{array}{r}181,050 \\
41,850 \\
128,680 \\
447,727 \\
114,920\end{array}$ & $\begin{array}{r}168,920 \\
36,565 \\
108,880 \\
294,840 \\
83,675\end{array}$ & $\begin{array}{r}12,130 \\
5,285 \\
19,800 \\
152,887 \\
31,245\end{array}$ & $\begin{array}{r}20,235 \\
1,165 \\
2,255 \\
18,478 \\
7,383\end{array}$ \\
\hline
\end{tabular}


Table 38.-Farms Operated by Negroes-Number, Acreage, and Value of Specified Classes of Farm Property, by States and Codnties, 1930Continued

\begin{tabular}{|c|c|c|c|c|c|c|}
\hline \multirow{2}{*}{ STATE AND COUNTY } & \multirow{2}{*}{$\begin{array}{l}\text { Number } \\
\text { of farms }\end{array}$} & \multirow{2}{*}{$\begin{array}{l}\text { Land in } \\
\text { farms } \\
\text { (acres) }\end{array}$} & \multicolumn{3}{|c|}{ VALUE OF LAND AND BUILDINGS } & \multirow{2}{*}{$\begin{array}{l}\text { Value of } \\
\text { imple- } \\
\text { ments and } \\
\text { machinery }\end{array}$} \\
\hline & & & Total & Land alone & Bulldings & \\
\hline & \multicolumn{6}{|c|}{ FLORIDA-continued } \\
\hline $\begin{array}{l}\text { Santa Rosa } \\
\text { Seminole } \\
\text { Sumter } \\
\text { Suwannee. } \\
\text { Taylor }\end{array}$ & $\begin{array}{r}28 \\
39 \\
121 \\
394 \\
14\end{array}$ & $\begin{array}{r}1,868 \\
617 \\
4,609 \\
31,322 \\
857\end{array}$ & $\begin{array}{r}\$ 73,300 \\
134,500 \\
163,195 \\
453,455 \\
32,800\end{array}$ & $\begin{array}{r}\$ 60,590 \\
103,700 \\
116,300 \\
331,510 \\
26,400\end{array}$ & $\begin{array}{r}\$ 12,710 \\
30,800 \\
46,895 \\
121,945 \\
6,400\end{array}$ & $\begin{array}{r}\$ 1,567 \\
4,935 \\
14,995 \\
14,967 \\
1,770\end{array}$ \\
\hline \multirow[t]{2}{*}{$\begin{array}{l}\text { Union } \\
\text { Volusia } \\
\text { Wakulla. } \\
\text { Walton } \\
\text { Washington } \\
\text { Other counties }\end{array}$} & $\begin{array}{r}78 \\
49 \\
126 \\
109 \\
160 \\
25\end{array}$ & $\begin{array}{l}4,297 \\
1,318 \\
5,624 \\
4,598 \\
8,087 \\
575\end{array}$ & $\begin{array}{r}98,700 \\
399,500 \\
115,296 \\
101,570 \\
183,480 \\
158,250\end{array}$ & $\begin{array}{r}63,490 \\
348,638 \\
76,611 \\
63,030 \\
121,460 \\
143,050\end{array}$ & $\begin{array}{l}35,210 \\
50,862 \\
38,685 \\
38,540 \\
62,020 \\
15,200\end{array}$ & $\begin{array}{l}2,409 \\
8,569 \\
3,716 \\
7,631 \\
9,442 \\
3,755\end{array}$ \\
\hline & - & . & \multicolumn{2}{|c|}{ GEORGIA } & & \\
\hline Tota. & 86,787 & $5,104,452$ & $\$ 114,688,230$ & $\$ 82,893,996$ & $\$ 31,794,234$ & $84,320,897$ \\
\hline $\begin{array}{l}\text { Appling } \\
\text { Atkinson } \\
\text { Bacon } \\
\text { Baker } \\
\text { Baldwin }\end{array}$ & $\begin{array}{r}191 \\
89 \\
60 \\
758 \\
589\end{array}$ & $\begin{array}{r}12,740 \\
6,493 \\
3,983 \\
49,230 \\
36,705\end{array}$ & $\begin{array}{r}256,125 \\
107,765 \\
84,077 \\
820,940 \\
546,172\end{array}$ & $\begin{array}{r}193,495 \\
77,865 \\
58,817 \\
630,655 \\
396,622\end{array}$ & $\begin{array}{r}62,630 \\
29,900 \\
25,260 \\
190,285 \\
149,550\end{array}$ & $\begin{array}{r}7,427 \\
3,440 \\
2,614 \\
47,651 \\
29,036\end{array}$ \\
\hline $\begin{array}{l}\text { Banks } \\
\text { Barrow } \\
\text { Bartow } \\
\text { Ben Hill } \\
\text { Berrien }\end{array}$ & $\begin{array}{l}148 \\
269 \\
375 \\
289 \\
114\end{array}$ & $\begin{array}{r}7,934 \\
11,731 \\
16,210 \\
24,761 \\
8,330\end{array}$ & $\begin{array}{l}184,925 \\
363,420 \\
659,292 \\
559,025 \\
167,530\end{array}$ & $\begin{array}{l}133,410 \\
256,545 \\
518,667 \\
402,640 \\
129,670\end{array}$ & $\begin{array}{r}51,515 \\
106,875 \\
140,625 \\
156,385 \\
\mathbf{3 7}, 860\end{array}$ & $\begin{array}{r}5,223 \\
15,410 \\
48,009 \\
25,195 \\
5,068\end{array}$ \\
\hline $\begin{array}{l}\text { Bibb } \\
\text { Bleckley- } \\
\text { Brantley } \\
\text { Brooks. } \\
\text { Bryan }\end{array}$ & $\begin{array}{r}370 \\
221 \\
34 \\
1,095 \\
152\end{array}$ & $\begin{array}{l}18,122 \\
12,466 \\
56,784 \\
12,649\end{array}$ & $\begin{array}{r}658,566 \\
283,035 \\
19,375 \\
1,385,609 \\
160,062\end{array}$ & $\begin{array}{r}465,857 \\
207,775 \\
11,685 \\
1,064,093 \\
113,837\end{array}$ & $\begin{array}{r}192,709 \\
75,260 \\
7,690 \\
321,516 \\
46,225\end{array}$ & $\begin{array}{r}19,134 \\
10,657 \\
676 \\
58,400 \\
6,393\end{array}$ \\
\hline $\begin{array}{l}\text { Bulloch. } \\
\text { Burke. } \\
\text { Butts } \\
\text { Calhoun } \\
\text { Camden }\end{array}$ & $\begin{array}{r}996 \\
3,036 \\
608 \\
1,227 \\
225\end{array}$ & $\begin{array}{r}57,449 \\
152,756 \\
33,331 \\
56,608 \\
10,532\end{array}$ & $\begin{array}{r}1,763,781 \\
3,542,106 \\
666,844 \\
1,676,852 \\
267,720\end{array}$ & $\begin{array}{r}1,309,826 \\
2,517,837 \\
452,010 \\
1,246,227 \\
195,565\end{array}$ & $\begin{array}{r}453,955 \\
1,024,269 \\
214,834 \\
430,625 \\
72,155\end{array}$ & $\begin{array}{r}52,228 \\
134,892 \\
27,386 \\
82,636 \\
8,874\end{array}$ \\
\hline $\begin{array}{l}\text { Campbell } \\
\text { Candler } \\
\text { Carroll } \\
\text { Catoosa } \\
\text { Charlton }\end{array}$ & $\begin{array}{r}362 \\
344 \\
1,080 \\
44 \\
19\end{array}$ & $\begin{array}{r}23,681 \\
20,720 \\
47,355 \\
3,481 \\
1,266\end{array}$ & $\begin{array}{r}557,035 \\
509,920 \\
1,618,292 \\
105,515 \\
18,500\end{array}$ & $\begin{array}{r}371,030 \\
385,950 \\
1,147,522 \\
83,465 \\
12,475\end{array}$ & $\begin{array}{r}186,005 \\
123,970 \\
470,770 \\
22,050 \\
6,025\end{array}$ & $\begin{array}{r}20,245 \\
9,840 \\
50,587 \\
2,762 \\
946\end{array}$ \\
\hline $\begin{array}{l}\text { Chatham } \\
\text { Chattahoochee } \\
\text { Chattooga. } \\
\text { Cherokee. }\end{array}$ & $\begin{array}{r}82 \\
172 \\
249 \\
72 \\
543\end{array}$ & $\begin{array}{r}6,027 \\
21,788 \\
18,616 \\
3,432 \\
21,701\end{array}$ & $\begin{array}{r}231,060 \\
154,836 \\
399,976 \\
96,695 \\
1,008,096\end{array}$ & $\begin{array}{r}196,270 \\
113,681 \\
306,010 \\
61,655 \\
714,691\end{array}$ & $\begin{array}{r}34,790 \\
41,155 \\
93,966 \\
35,040 \\
293,405\end{array}$ & $\begin{array}{r}4,263 \\
9,336 \\
24,466 \\
3,685 \\
32,953\end{array}$ \\
\hline $\begin{array}{l}\text { Clay } \\
\text { Clayton } \\
\text { Clinch } \\
\text { Cobb } \\
\text { Coffee. }\end{array}$ & $\begin{array}{r}645 \\
365 \\
45 \\
536 \\
306\end{array}$ & $\begin{array}{r}37,849 \\
16,355 \\
2,638 \\
22,533 \\
23,951\end{array}$ & $\begin{array}{r}837,305 \\
634,285 \\
46,100 \\
930,835 \\
445,785\end{array}$ & $\begin{array}{r}603,570 \\
467,670 \\
28,295 \\
693,200 \\
313,790\end{array}$ & $\begin{array}{l}233,735 \\
166,615 \\
17,805 \\
237,635 \\
131,995\end{array}$ & $\begin{array}{r}34,006 \\
15,234 \\
2,260 \\
26,993 \\
19,844\end{array}$ \\
\hline $\begin{array}{l}\text { Colquitt } \\
\text { Columbia } \\
\text { Cook } \\
\text { Coweta } \\
\text { Craw ford. }\end{array}$ & $\begin{array}{r}434 \\
801 \\
200 \\
1,134 \\
477\end{array}$ & $\begin{array}{l}24,012 \\
41,072 \\
13,593 \\
74,205 \\
44,250\end{array}$ & $\begin{array}{r}1,079,899 \\
751,727 \\
381,116 \\
1,457,382 \\
539,519\end{array}$ & $\begin{array}{r}872,064 \\
464,942 \\
289,696 \\
1,060,745 \\
364,904\end{array}$ & $\begin{array}{r}207,835 \\
286,785 \\
91,420 \\
396,637 \\
174,615\end{array}$ & $\begin{array}{l}23,977 \\
29,929 \\
13,104 \\
58,161 \\
20,258\end{array}$ \\
\hline $\begin{array}{l}\text { Crisp } \\
\text { Dade } \\
\text { Decatur } \\
\text { De Kalb. } \\
\text { Dodge }\end{array}$ & $\begin{array}{r}605 \\
10 \\
636 \\
511 \\
790\end{array}$ & $\begin{array}{r}38,020 \\
536 \\
41,469 \\
19,959 \\
50,074\end{array}$ & $\begin{array}{r}1,083,827 \\
13,680 \\
784,895 \\
1,144,910 \\
1,327,555\end{array}$ & $\begin{array}{r}853,252 \\
11,105 \\
584,525 \\
953,445 \\
957,445\end{array}$ & $\begin{array}{r}230,575 \\
2,575 \\
200,370 \\
191,465 \\
370,110\end{array}$ & $\begin{array}{r}32,634 \\
460 \\
31,939 \\
15,268 \\
54,177\end{array}$ \\
\hline
\end{tabular}


Table 38. - Farms Operated by Negroes-Number, Acreage, and Value of Specified Classes of Farm Property, by States and Counties, 1930Continued

\begin{tabular}{|c|c|c|c|c|c|c|}
\hline \multirow{2}{*}{ STATE AND COUNTY } & \multirow{2}{*}{$\begin{array}{l}\text { Number } \\
\text { of farms }\end{array}$} & \multirow{2}{*}{$\begin{array}{l}\text { Land in } \\
\text { farms } \\
\text { (acres) }\end{array}$} & \multicolumn{3}{|c|}{ VALUE OF LAND AND BUILDINGS } & \multirow{2}{*}{$\begin{array}{l}\text { Value of } \\
\text { imple- } \\
\text { ments and } \\
\text { machinery }\end{array}$} \\
\hline & & & Total & Land alone & Buildings & \\
\hline & \multicolumn{6}{|c|}{ GEORGIA-continued } \\
\hline $\begin{array}{l}\text { Dooly } \\
\text { Dougherty } \\
\text { Douglas. } \\
\text { Early } \\
\text { Echols.... }\end{array}$ & $\begin{array}{r}1,351 \\
459 \\
302 \\
1,624 \\
17\end{array}$ & $\begin{array}{r}72,572 \\
26,026 \\
18,795 \\
79,056 \\
1,196\end{array}$ & $\begin{array}{r}\$ 1,906,413 \\
698,185 \\
435,696 \\
2,141,161 \\
15,650\end{array}$ & $\begin{array}{r}\$ 1,478,783 \\
543,060 \\
288,576 \\
1,503,828 \\
10,825\end{array}$ & $\begin{array}{r}\$ 427,630 \\
155,125 \\
147,120 \\
637,333 \\
4,825\end{array}$ & $\begin{array}{r}\$ 75,564 \\
34,316 \\
17,289 \\
93,209 \\
935\end{array}$ \\
\hline $\begin{array}{l}\text { Effingham } \\
\text { Elbert } \\
\text { Emanuel. } \\
\text { Evans. } \\
\text { Fayette.... }\end{array}$ & $\begin{array}{r}257 \\
997 \\
1,064 \\
210 \\
502\end{array}$ & $\begin{array}{r}9,271 \\
52,999 \\
66,783 \\
13,699 \\
24,577\end{array}$ & $\begin{array}{r}205,986 \\
1,090,225 \\
1,815,766 \\
350,165 \\
544,285\end{array}$ & $\begin{array}{r}150,546 \\
741,908 \\
1,376,172 \\
244,365 \\
385,635\end{array}$ & $\begin{array}{r}55,440 \\
348,317 \\
439,594 \\
105,800 \\
158,650\end{array}$ & $\begin{array}{r}5,379 \\
56,188 \\
59,212 \\
9,438 \\
22,449\end{array}$ \\
\hline $\begin{array}{l}\text { Floyd } \\
\text { Franklin. } \\
\text { Fulton } \\
\text { Glascock } \\
\text { Glynn }\end{array}$ & $\begin{array}{r}506 \\
395 \\
185 \\
183 \\
65\end{array}$ & $\begin{array}{r}28,130 \\
13,794 \\
5,906 \\
11,922 \\
4,621\end{array}$ & $\begin{array}{l}690,081 \\
466,140 \\
802,125 \\
213,410 \\
106,880\end{array}$ & $\begin{array}{r}521,966 \\
332,675 \\
693,040 \\
148,260 \\
75,430\end{array}$ & $\begin{array}{r}168,115 \\
133,465 \\
109,085 \\
65,150 \\
31,450\end{array}$ & $\begin{array}{r}33,381 \\
9,994 \\
15,130 \\
10,032 \\
5,445\end{array}$ \\
\hline $\begin{array}{l}\text { Gordon } \\
\text { Grady } \\
\text { Greene } \\
\text { Gwinnett. } \\
\text { Habersham }\end{array}$ & $\begin{array}{r}99 \\
435 \\
942 \\
316 \\
31\end{array}$ & $\begin{array}{r}5,526 \\
28,265 \\
56,633 \\
16,956 \\
2,121\end{array}$ & $\begin{array}{r}199,040 \\
684,160 \\
780,613 \\
394,655 \\
58,300\end{array}$ & $\begin{array}{r}163,825 \\
513,625 \\
454,357 \\
286,655 \\
40,435\end{array}$ & $\begin{array}{r}35,215 \\
170,535 \\
326,256 \\
108,000 \\
17,865\end{array}$ & $\begin{array}{r}9,050 \\
21,359 \\
38,724 \\
13,515 \\
1,990\end{array}$ \\
\hline $\begin{array}{l}\text { Hall } \\
\text { Hancock } \\
\text { Haralson... } \\
\text { Harris. } \\
\text { Hart }\end{array}$ & $\begin{array}{r}216 \\
1,205 \\
165 \\
1,014 \\
612\end{array}$ & $\begin{array}{r}12,021 \\
58,474 \\
9,332 \\
93,074 \\
26,469\end{array}$ & $\begin{array}{r}259,400 \\
808,464 \\
178,300 \\
1,078,035 \\
817,722\end{array}$ & $\begin{array}{l}186,045 \\
550,617 \\
121,205 \\
695,595 \\
579,962\end{array}$ & $\begin{array}{r}73,355 \\
257,847 \\
57,095 \\
382,440 \\
237,760\end{array}$ & $\begin{array}{r}7,297 \\
35,294 \\
7,078 \\
36,727 \\
24,866\end{array}$ \\
\hline $\begin{array}{l}\text { Heard } \\
\text { Henry } \\
\text { Houston } \\
\text { Irwin } \\
\text { Jackson }\end{array}$ & $\begin{array}{r}411 \\
1,213 \\
772 \\
471 \\
596\end{array}$ & $\begin{array}{l}30,800 \\
58,713 \\
61,681 \\
32,846 \\
25,587\end{array}$ & $\begin{array}{r}444,064 \\
1,345,854 \\
1,176,557 \\
871,135 \\
759,552\end{array}$ & $\begin{array}{l}237,289 \\
926,179 \\
908,634 \\
699,045 \\
517,526\end{array}$ & $\begin{array}{l}206,775 \\
419,675 \\
267,923 \\
172,090 \\
242,026\end{array}$ & $\begin{array}{l}20,561 \\
46,945 \\
34,864 \\
32,935 \\
22,165\end{array}$ \\
\hline $\begin{array}{l}\text { Jasper. } \\
\text { Jeff Davis } \\
\text { Jefferson } \\
\text { Jenkins } \\
\text { Johnson }\end{array}$ & $\begin{array}{r}622 \\
125 \\
1,497 \\
958 \\
584\end{array}$ & $\begin{array}{r}54,179 \\
7,631 \\
93,831 \\
43,600 \\
29,524\end{array}$ & $\begin{array}{r}790,505 \\
158,718 \\
1,689,193 \\
1,100,080 \\
622,533\end{array}$ & $\begin{array}{r}489,360 \\
103,393 \\
1,205,557 \\
829,253 \\
447,378\end{array}$ & $\begin{array}{r}301,145 \\
55,325 \\
483,636 \\
270,827 \\
175,155\end{array}$ & $\begin{array}{r}40,034 \\
8,954 \\
70,315 \\
45,378 \\
18,075\end{array}$ \\
\hline $\begin{array}{l}\text { Jones... } \\
\text { Lamar. } \\
\text { Lanier } \\
\text { Laurens... } \\
\text { Lee...... }\end{array}$ & $\begin{array}{r}472 \\
455 \\
116 \\
1,558 \\
935\end{array}$ & $\begin{array}{r}45,417 \\
30,199 \\
9,910 \\
82,690 \\
57,702\end{array}$ & $\begin{array}{r}516,208 \\
773,980 \\
199,110 \\
1,824,855 \\
1,153,570\end{array}$ & $\begin{array}{r}362,468 \\
504,290 \\
130,790 \\
1,345,275 \\
848,668\end{array}$ & $\begin{array}{r}153,740 \\
269,690 \\
68,320 \\
479,580 \\
304,902\end{array}$ & $\begin{array}{l}11,775 \\
30,348 \\
12,430 \\
65,493 \\
64,352\end{array}$ \\
\hline $\begin{array}{l}\text { Liberty } \\
\text { Lincoln } \\
\text { Long } \\
\text { Lowndes } \\
\text { Lumpkin. }\end{array}$ & $\begin{array}{r}834 \\
777 \\
152 \\
739 \\
18\end{array}$ & $\begin{array}{r}33,196 \\
35,037 \\
9,186 \\
39,070 \\
1,154\end{array}$ & $\begin{array}{r}826,394 \\
652,229 \\
158,130 \\
1,268,469 \\
17,090\end{array}$ & $\begin{array}{r}461,963 \\
429,674 \\
94,955 \\
988,158 \\
14,090\end{array}$ & $\begin{array}{r}364,431 \\
222,555 \\
63,175 \\
280,311 \\
3,000\end{array}$ & $\begin{array}{r}43,166 \\
35,574 \\
9,419 \\
30,889 \\
400\end{array}$ \\
\hline $\begin{array}{l}\text { MeDuffie } \\
\text { McIntosh } \\
\text { Macon } \\
\text { Madison } \\
\text { Marion....... }\end{array}$ & $\begin{array}{r}626 \\
181 \\
1,245 \\
398 \\
533\end{array}$ & $\begin{array}{r}30,858 \\
5,600 \\
79,002 \\
19,035 \\
49,738\end{array}$ & $\begin{array}{r}470,397 \\
154,600 \\
2,054,503 \\
479,225 \\
573,220\end{array}$ & $\begin{array}{r}305,847 \\
89,690 \\
1,672,418 \\
346,235 \\
339,265\end{array}$ & $\begin{array}{r}164,550 \\
64,910 \\
382,085 \\
132,990 \\
233,955\end{array}$ & $\begin{array}{r}21,643 \\
7,453 \\
63,569 \\
14,052 \\
17,937\end{array}$ \\
\hline $\begin{array}{l}\text { Meriwether } \\
\text { Miller } \\
\text { Milton } \\
\text { Mitchell } \\
\text { Monroe }\end{array}$ & $\begin{array}{r}1,299 \\
434 \\
69 \\
1,352 \\
763\end{array}$ & $\begin{array}{r}101,264 \\
21,794 \\
2,509 \\
68,154 \\
62,282\end{array}$ & $\begin{array}{r}1,844,780 \\
543,140 \\
100,467 \\
2,124,455 \\
758,956\end{array}$ & $\begin{array}{r}1,193,600 \\
387,655 \\
76,137 \\
1,567,112 \\
514,638\end{array}$ & $\begin{array}{r}651,180 \\
155,485 \\
24,330 \\
557,343 \\
244,318\end{array}$ & $\begin{array}{r}69,938 \\
23,647 \\
2,140 \\
72,582 \\
29,938\end{array}$ \\
\hline $\begin{array}{l}\text { Montgomery } \\
\text { Morgan } \\
\text { Murray } \\
\text { Muscogee } \\
\text { Newton }\end{array}$ & $\begin{array}{r}531 \\
1,019 \\
47 \\
317 \\
835\end{array}$ & $\begin{array}{r}29,810 \\
51,353 \\
2,029 \\
22,004 \\
44,114\end{array}$ & $\begin{array}{r}889,285 \\
1,039,573 \\
74,314 \\
479,330 \\
1,011,166\end{array}$ & $\begin{array}{r}712,610 \\
627,983 \\
52,864 \\
360,880 \\
682,806\end{array}$ & $\begin{array}{r}176,675 \\
411,590 \\
21,450 \\
118,450 \\
328,360\end{array}$ & $\begin{array}{r}20,593 \\
53,425 \\
4,620 \\
18,430 \\
44,591\end{array}$ \\
\hline
\end{tabular}


Table 38. - Farms Operated by Negroes-Number, Acreage, and Value of Specified Classes of Farm Property, by States and Counties, 1930Continued

\begin{tabular}{|c|c|c|c|c|c|c|}
\hline \multirow{2}{*}{ STATE AND COUNTY } & \multirow{2}{*}{$\begin{array}{l}\text { Number } \\
\text { of farms }\end{array}$} & \multirow{2}{*}{$\begin{array}{l}\text { Land in } \\
\text { farms } \\
\text { (acres) }\end{array}$} & \multicolumn{3}{|c|}{ VALUE OF LAND AND BUILDINGS } & \multirow{2}{*}{$\begin{array}{l}\text { Value of } \\
\text { imple- } \\
\text { ments and } \\
\text { machinery }\end{array}$} \\
\hline & & & Total & Land alone & Buildings & \\
\hline & \multicolumn{6}{|c|}{ GEORGIA-continued } \\
\hline $\begin{array}{l}\text { Oconee } \\
\text { Oglethorpe } \\
\text { Paulding } \\
\text { Peach } \\
\text { Pickens.................. }\end{array}$ & $\begin{array}{r}363 \\
933 \\
186 \\
492 \\
8\end{array}$ & $\begin{array}{r}22,478 \\
62,025 \\
9,790 \\
19,027 \\
549\end{array}$ & $\begin{array}{r}\$ 452,473 \\
1,032,493 \\
186,815 \\
770,019 \\
20,250\end{array}$ & $\begin{array}{r}\$ 300,923 \\
678,417 \\
114,790 \\
623,099 \\
16,375\end{array}$ & $\begin{array}{r}\$ 151,550 \\
354,076 \\
72,025 \\
146,920 \\
3,875\end{array}$ & $\begin{array}{r}\$ 22,190 \\
46,283 \\
7,805 \\
20,292 \\
222\end{array}$ \\
\hline $\begin{array}{l}\text { Pierce } \\
\text { Pike } \\
\text { Polk. } \\
\text { Pulaski... } \\
\text { Putnam }\end{array}$ & $\begin{array}{l}191 \\
710 \\
374 \\
536 \\
632\end{array}$ & $\begin{array}{l}12,152 \\
38,767 \\
18,448 \\
31,725 \\
48,569\end{array}$ & $\begin{array}{r}330,630 \\
1,007,015 \\
499,884 \\
781,100 \\
717,121\end{array}$ & $\begin{array}{l}225,975 \\
669,794 \\
376,484 \\
593,060 \\
469,871\end{array}$ & $\begin{array}{l}104,655 \\
337,221 \\
123,400 \\
188,040 \\
247,250\end{array}$ & $\begin{array}{l}10,235 \\
35,908 \\
26,267 \\
33,181 \\
24,559\end{array}$ \\
\hline $\begin{array}{l}\text { Quitman } \\
\text { Rabun } \\
\text { Randolph } \\
\text { Richmond... } \\
\text { Rockdale.... }\end{array}$ & $\begin{array}{r}326 \\
11 \\
1,502 \\
377 \\
323\end{array}$ & $\begin{array}{r}26,123 \\
234 \\
91,991 \\
26,956 \\
18,896\end{array}$ & $\begin{array}{r}404,875 \\
20,800 \\
2,249,739 \\
580,415 \\
303,940\end{array}$ & $\begin{array}{r}277,780 \\
9,400 \\
1,743,362 \\
409,850 \\
200,898\end{array}$ & $\begin{array}{r}127,095 \\
11,400 \\
506,377 \\
170,565 \\
103,042\end{array}$ & $\begin{array}{r}21,557 \\
355 \\
89,695 \\
28,602 \\
13,035\end{array}$ \\
\hline $\begin{array}{l}\text { Schley } \\
\text { Sereven } \\
\text { Seminole } \\
\text { Spalding } \\
\text { Stephens......... }\end{array}$ & $\begin{array}{r}419 \\
1,561 \\
319 \\
517 \\
152\end{array}$ & $\begin{array}{r}31,594 \\
67,050 \\
18,823 \\
28,965 \\
7,040\end{array}$ & $\begin{array}{r}567,902 \\
1,509,535 \\
482,085 \\
737,514 \\
235,890\end{array}$ & $\begin{array}{r}429,057 \\
1,103,306 \\
345,925 \\
458,768 \\
179,330\end{array}$ & $\begin{array}{r}138,845 \\
406,229 \\
136,160 \\
278,746 \\
56,560\end{array}$ & $\begin{array}{r}21,933 \\
37,111 \\
20,881 \\
29,231 \\
5,529\end{array}$ \\
\hline $\begin{array}{l}\text { Stewart } \\
\text { Sumter } \\
\text { Talbot } \\
\text { Taliaferro } \\
\text { Tattnall }\end{array}$ & $\begin{array}{r}874 \\
1,419 \\
641 \\
626 \\
294\end{array}$ & $\begin{array}{l}96,080 \\
75,449 \\
54,626 \\
38,892 \\
17,446\end{array}$ & $\begin{array}{r}1,208,350 \\
2,137,388 \\
707,280 \\
477,980 \\
443,391\end{array}$ & $\begin{array}{r}897,865 \\
1,656,123 \\
437,305 \\
317,130 \\
324,781\end{array}$ & $\begin{array}{l}310,485 \\
481,265 \\
269,975 \\
160,850 \\
118,610\end{array}$ & $\begin{array}{l}58,864 \\
56,264 \\
30,900 \\
17,138 \\
12,967\end{array}$ \\
\hline $\begin{array}{l}\text { Taylor. } \\
\text { Telfair } \\
\text { Terrell... } \\
\text { Thomas } \\
\text { Tift_... }\end{array}$ & $\begin{array}{r}579 \\
405 \\
1,658 \\
960 \\
253\end{array}$ & $\begin{array}{l}36,090 \\
26,402 \\
79,502 \\
57,029 \\
12,976\end{array}$ & $\begin{array}{r}628,878 \\
565,281 \\
3,696,058 \\
1,365,472 \\
483,893\end{array}$ & $\begin{array}{r}457,708 \\
427,546 \\
2,907,542 \\
1,014,167 \\
382,648\end{array}$ & $\begin{array}{l}171,170 \\
137,735 \\
788,516 \\
351,305 \\
101,245\end{array}$ & $\begin{array}{r}17,307 \\
20,212 \\
117,906 \\
34,259 \\
10,925\end{array}$ \\
\hline $\begin{array}{l}\text { Toombs... } \\
\text { Treutlen. } \\
\text { Troup } \\
\text { Turner....... } \\
\text { Twiggs........ }\end{array}$ & $\begin{array}{r}434 \\
256 \\
1,067 \\
351 \\
485\end{array}$ & $\begin{array}{l}23,057 \\
16,820 \\
78,133 \\
21,719 \\
30,010\end{array}$ & $\begin{array}{r}767,877 \\
478,924 \\
1,449,970 \\
627,224 \\
437,359\end{array}$ & $\begin{array}{l}626,957 \\
344,724 \\
971,417 \\
507,769 \\
294,727\end{array}$ & $\begin{array}{l}140,920 \\
134,200 \\
478,553 \\
119,455 \\
142,632\end{array}$ & $\begin{array}{l}19,340 \\
18,123 \\
60,597 \\
25,169 \\
27,434\end{array}$ \\
\hline $\begin{array}{l}\text { Upson } \\
\text { Walker } \\
\text { Walton } \\
\text { Ware } \\
\text { Warren }\end{array}$ & $\begin{array}{r}457 \\
217 \\
907 \\
78 \\
977\end{array}$ & $\begin{array}{r}48,129 \\
8,625 \\
46,837 \\
4,037 \\
60,955\end{array}$ & $\begin{array}{r}707,275 \\
306,075 \\
1,141,465 \\
174,325 \\
1,015,372\end{array}$ & $\begin{array}{l}461,530 \\
230,105 \\
791,475 \\
111,375 \\
736,187\end{array}$ & $\begin{array}{r}245,745 \\
75,970 \\
349,990 \\
62,950 \\
279,185\end{array}$ & $\begin{array}{r}29,539 \\
11,265 \\
62,023 \\
7,785 \\
40,282\end{array}$ \\
\hline $\begin{array}{l}\text { Washington. } \\
\text { Wayne. } \\
\text { Webster. } \\
\text { Wheeler. } \\
\text { White }\end{array}$ & $\begin{array}{r}1,782 \\
76 \\
421 \\
323 \\
36\end{array}$ & $\begin{array}{r}88,655 \\
6,678 \\
27,845 \\
20,458 \\
1,979\end{array}$ & $\begin{array}{r}1,578,000 \\
106,815 \\
363,480 \\
464,375 \\
42,060\end{array}$ & $\begin{array}{r}1,039,308 \\
80,380 \\
223,932 \\
359,279 \\
34,435\end{array}$ & $\begin{array}{r}538,692 \\
26,435 \\
139,548 \\
105,096 \\
7,625\end{array}$ & $\begin{array}{r}54,595 \\
3,740 \\
27,783 \\
14,581 \\
302\end{array}$ \\
\hline $\begin{array}{l}\text { Whitfield. } \\
\text { Wilcox } \\
\text { Wilkes. } \\
\text { Wilkinson } \\
\text { Worth } \\
\text { Other counties.... }\end{array}$ & $\begin{array}{r}57 \\
690 \\
1,465 \\
478 \\
1,175 \\
10\end{array}$ & $\begin{array}{r}2,980 \\
47,088 \\
77,367 \\
39,142 \\
59,818 \\
398\end{array}$ & $\begin{array}{r}93,800 \\
1,018,675 \\
1,148,596 \\
414,895 \\
1,722,150 \\
6,592\end{array}$ & $\begin{array}{r}70,710 \\
780,710 \\
733,345 \\
317,625 \\
1,268,750 \\
4,407\end{array}$ & $\begin{array}{r}23,090 \\
237,965 \\
415,251 \\
97,270 \\
453,400 \\
2,185\end{array}$ & $\begin{array}{r}5,419 \\
32,899 \\
35,761 \\
13,278 \\
79,171 \\
130\end{array}$ \\
\hline 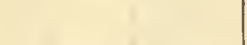 & \multicolumn{6}{|c|}{ IDAHO } \\
\hline Total. & 16 & 2,816 & 8107,200 & 879,550 & 827,650 & 814,125 \\
\hline
\end{tabular}


Table 38. - Farms Operated by Negroes-Number, Acreage, and Value of Specified Classes of Farm Property, by States and Counties, 1930Continued

\begin{tabular}{|c|c|c|c|c|c|c|}
\hline \multirow{2}{*}{ STATE AND COUNTY } & \multirow{2}{*}{$\begin{array}{l}\text { Number } \\
\text { of farms }\end{array}$} & \multirow{2}{*}{$\begin{array}{l}\text { Land in } \\
\text { farms } \\
\text { (acres) }\end{array}$} & \multicolumn{3}{|c|}{ VALUE OF LAND AND BUILDINGS } & \multirow{2}{*}{$\begin{array}{l}\text { Value of } \\
\text { imple- } \\
\text { ments and } \\
\text { machinery }\end{array}$} \\
\hline & & & Total & Land alone & Buildings & \\
\hline & \multicolumn{6}{|c|}{ II.LINOIS } \\
\hline Total & 898 & 57,805 & $83,704,618$ & \$2, 926, 618 & 8778,000 & 8128,810 \\
\hline $\begin{array}{l}\text { Alexander } \\
\text { Bond } \\
\text { Henderson } \\
\text { Jackson } \\
\text { Jefferson }\end{array}$ & $\begin{array}{r}138 \\
5 \\
5 \\
22 \\
7\end{array}$ & $\begin{array}{r}6,871 \\
566 \\
672 \\
1,658 \\
485\end{array}$ & $\begin{array}{r}377,192 \\
12,495 \\
44,200 \\
68,050 \\
12,150\end{array}$ & $\begin{array}{r}323,572 \\
9,095 \\
39,300 \\
49,900 \\
6,500\end{array}$ & $\begin{array}{r}53,620 \\
3,400 \\
4,900 \\
18,150 \\
5,650\end{array}$ & $\begin{array}{r}9,322 \\
525 \\
2,500 \\
2,610 \\
512\end{array}$ \\
\hline $\begin{array}{l}\text { Johnson } \\
\text { Kankakee } \\
\text { Lawrence-2. } \\
\text { Madison } \\
\text { Marion }\end{array}$ & $\begin{array}{r}8 \\
9 \\
14 \\
45 \\
5\end{array}$ & $\begin{array}{r}911 \\
1,911 \\
1,203 \\
2,394 \\
117\end{array}$ & $\begin{array}{r}13,000 \\
76,100 \\
52,700 \\
181,865 \\
8,900\end{array}$ & $\begin{array}{r}8,600 \\
59,900 \\
38,600 \\
91,350 \\
3,540\end{array}$ & $\begin{array}{r}4,400 \\
16,200 \\
14,100 \\
90,515 \\
5,360\end{array}$ & $\begin{array}{r}650 \\
1,525 \\
1,925 \\
8,520 \\
145\end{array}$ \\
\hline $\begin{array}{l}\text { Massac. } \\
\text { Perry } \\
\text { Pope } \\
\text { Pulaski } \\
\text { Randolph }\end{array}$ & $\begin{array}{r}79 \\
9 \\
23 \\
306 \\
28\end{array}$ & $\begin{array}{r}4,804 \\
962 \\
1,750 \\
14,277 \\
1,944\end{array}$ & $\begin{array}{r}183,960 \\
38,520 \\
40,435 \\
565,586 \\
76,920\end{array}$ & $\begin{array}{r}143,095 \\
24,720 \\
31,500 \\
429,761 \\
53,420\end{array}$ & $\begin{array}{r}40,865 \\
13,800 \\
8,935 \\
135,825 \\
23,500\end{array}$ & $\begin{array}{r}7,065 \\
1,602 \\
1,265 \\
25,890 \\
2,215\end{array}$ \\
\hline $\begin{array}{l}\text { St. Clair..... } \\
\text { Saline...... } \\
\text { Sangamon... } \\
\text { Vermilion... }\end{array}$ & $\begin{array}{l}23 \\
38 \\
16 \\
10\end{array}$ & $\begin{array}{r}942 \\
2,857 \\
403 \\
456\end{array}$ & $\begin{array}{r}208,600 \\
145,440 \\
76,675 \\
56,600\end{array}$ & $\begin{array}{r}196,225 \\
110,215 \\
49,375 \\
44,345\end{array}$ & $\begin{array}{l}12,375 \\
35,225 \\
27,300 \\
12,255\end{array}$ & $\begin{array}{l}2,232 \\
6,822 \\
1,220 \\
1,475\end{array}$ \\
\hline \multirow[t]{3}{*}{ 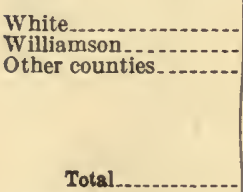 } & $\begin{array}{r}12 \\
8 \\
83\end{array}$ & $\begin{array}{r}1,294 \\
601 \\
10,727\end{array}$ & $\begin{array}{r}71,500 \\
13,000 \\
1,380,730\end{array}$ & $\begin{array}{r}61,900 \\
8,575 \\
1,143,130\end{array}$ & $\begin{array}{r}9,600 \\
4,425 \\
237,600\end{array}$ & $\begin{array}{r}2,445 \\
660 \\
45,685\end{array}$ \\
\hline & \multicolumn{6}{|c|}{ INDIANA } \\
\hline & 461 & 28,454 & $81,947,815$ & $81,358,595$ & 8588,320 & 877,162 \\
\hline $\begin{array}{l}\text { Bartholomew } \\
\text { Clark } \\
\text { Daviess } \\
\text { Dearborn } \\
\text { Delaware................ }\end{array}$ & $\begin{array}{r}5 \\
23 \\
11 \\
12 \\
5\end{array}$ & $\begin{array}{l}253 \\
767 \\
670 \\
470 \\
282\end{array}$ & $\begin{array}{l}15,910 \\
78,725 \\
60,450 \\
32,900 \\
38,200\end{array}$ & $\begin{array}{l}14,710 \\
50,900 \\
46,950 \\
22,750 \\
33,150\end{array}$ & $\begin{array}{r}1,200 \\
27,825 \\
13,500 \\
10,150 \\
5,050\end{array}$ & $\begin{array}{r}387 \\
2,815 \\
1,410 \\
1,215 \\
325\end{array}$ \\
\hline $\begin{array}{l}\text { Floyd } \\
\text { Gibson } \\
\text { Grant } \\
\text { Hamilon } \\
\text { Harrison }\end{array}$ & $\begin{array}{l}14 \\
63 \\
20 \\
18 \\
10\end{array}$ & $\begin{array}{r}678 \\
5,126 \\
1,141 \\
1,335 \\
852\end{array}$ & $\begin{array}{r}31,800 \\
249,940 \\
124,890 \\
112,750 \\
19,100\end{array}$ & $\begin{array}{r}15,450 \\
191,840 \\
66,690 \\
68,500 \\
13,550\end{array}$ & $\begin{array}{r}16,350 \\
58,100 \\
58,200 \\
44,250 \\
5,550\end{array}$ & $\begin{array}{r}768 \\
10,565 \\
2,770 \\
3,548 \\
1,057\end{array}$ \\
\hline $\begin{array}{l}\text { Henry } \\
\text { Jefferson } \\
\text { Jennings................... } \\
\text { Marion } \\
\text { Randolph. }\end{array}$ & $\begin{array}{l}10 \\
11 \\
11 \\
29 \\
17\end{array}$ & $\begin{array}{r}483 \\
378 \\
705 \\
1,020 \\
821\end{array}$ & $\begin{array}{r}42,200 \\
16,540 \\
27,200 \\
201,800 \\
46,195\end{array}$ & $\begin{array}{r}29,600 \\
9,040 \\
16,325 \\
166,345 \\
26,545\end{array}$ & $\begin{array}{r}12,600 \\
7,500 \\
10,875 \\
35,455 \\
19,650\end{array}$ & $\begin{array}{r}1,475 \\
390 \\
1,600 \\
6,570 \\
1,730\end{array}$ \\
\hline $\begin{array}{l}\text { Rush } \\
\text { Shelby } \\
\text { Spencer } \\
\text { Sullivan } \\
\text { Vanderburg }\end{array}$ & $\begin{array}{r}9 \\
7 \\
25 \\
10 \\
7\end{array}$ & $\begin{array}{r}663 \\
463 \\
1,120 \\
536 \\
377\end{array}$ & $\begin{array}{l}57,620 \\
43,050 \\
52,470 \\
21,635 \\
32,950\end{array}$ & $\begin{array}{l}47,220 \\
30,050 \\
40,295 \\
15,060 \\
30,250\end{array}$ & $\begin{array}{r}10,400 \\
13,000 \\
12,175 \\
6,575 \\
2,700\end{array}$ & $\begin{array}{r}2,460 \\
2,670 \\
1,550 \\
515 \\
500\end{array}$ \\
\hline \multirow[t]{2}{*}{$\begin{array}{l}\text { Vigo } \\
\text { Warrick } \\
\text { Wayne.... } \\
\text { Other counties...... }\end{array}$} & $\begin{array}{r}33 \\
6 \\
31 \\
74\end{array}$ & $\begin{array}{r}1,674 \\
315 \\
2,288 \\
6,037\end{array}$ & $\begin{array}{r}89,120 \\
15,600 \\
194,615 \\
\mathbf{3 4 2}, 255\end{array}$ & $\begin{array}{r}53,820 \\
7,900 \\
121,415 \\
240,240\end{array}$ & $\begin{array}{r}35,300 \\
7,700 \\
73,200 \\
102,015\end{array}$ & $\begin{array}{r}2,460 \\
1,175 \\
10,565 \\
18,642\end{array}$ \\
\hline & \multicolumn{6}{|c|}{ IOWA } \\
\hline Total.-- & 118 & 10,002 & 8878,234 & $\$ 860,745$ & 8217,488 & 846,001 \\
\hline $\begin{array}{l}\text { Fayette. } \\
\text { Lee } \\
\text { Monroe } \\
\text { Page } \\
\text { Polk } \\
\text { Other counties... }\end{array}$ & $\begin{array}{r}10 \\
24 \\
17 \\
6 \\
15 \\
46\end{array}$ & $\begin{array}{r}1,895 \\
1,926 \\
846 \\
379 \\
219 \\
4,737\end{array}$ & $\begin{array}{r}117,690 \\
86,845 \\
84,150 \\
50,500 \\
55,839 \\
483,210\end{array}$ & $\begin{array}{r}90,090 \\
63,920 \\
62,475 \\
43,600 \\
43,900 \\
356,760\end{array}$ & $\begin{array}{r}27,600 \\
22,925 \\
21,675 \\
6,900 \\
11,939 \\
126,450\end{array}$ & $\begin{array}{r}7,700 \\
4,207 \\
5,310 \\
1,725 \\
919 \\
26,140\end{array}$ \\
\hline
\end{tabular}


Table 38.-Farms Operated by Negroes-Number, Acreage, and Valde of Specified Classes of Farm Property, by States and Counties, 1930Continued

\begin{tabular}{|c|c|c|c|c|c|c|}
\hline \multirow{2}{*}{ STATE AND COU } & \multirow{2}{*}{$\begin{array}{l}\text { Number } \\
\text { of farms }\end{array}$} & \multirow{2}{*}{$\begin{array}{l}\text { Land in } \\
\text { farms } \\
\text { (acres) }\end{array}$} & \multicolumn{3}{|c|}{ VALUE OF LAND AND BUILDINGS } & \multirow{2}{*}{$\begin{array}{l}\text { Value of } \\
\text { imple- } \\
\text { ments and } \\
\text { machinery }\end{array}$} \\
\hline & & & Total & Land alone & Buildings & \\
\hline & \multicolumn{6}{|c|}{ KANSAS } \\
\hline Total & 941 & 146,745 & $\$ 6,093,760$ & $85,090,775$ & $\$ 1,002,885$ & $\$ 287,075$ \\
\hline $\begin{array}{l}\text { Anderson } \\
\text { Atchison } \\
\text { Barton } \\
\text { Bourbon } \\
\text { Chautauqua }\end{array}$ & $\begin{array}{r}5 \\
34 \\
13 \\
10 \\
10\end{array}$ & $\begin{array}{r}599 \\
3,800 \\
2,491 \\
877 \\
701\end{array}$ & $\begin{array}{r}34,100 \\
247,210 \\
147,600 \\
36,400 \\
28,550\end{array}$ & $\begin{array}{r}27,600 \\
199,085 \\
131,825 \\
29,400 \\
25,650\end{array}$ & $\begin{array}{r}6,500 \\
48,125 \\
15,775 \\
7,000 \\
2,900\end{array}$ & $\begin{array}{r}1,570 \\
7,240 \\
5,300 \\
560 \\
325\end{array}$ \\
\hline $\begin{array}{l}\text { Cherokee } \\
\text { Coffey } \\
\text { Cowley } \\
\text { Crawford } \\
\text { Doniphan }\end{array}$ & $\begin{array}{r}22 \\
5 \\
5 \\
9 \\
25\end{array}$ & $\begin{array}{r}2,074 \\
191 \\
364 \\
353 \\
2,347\end{array}$ & $\begin{array}{r}96,615 \\
10,040 \\
16,700 \\
11,650 \\
203,550\end{array}$ & $\begin{array}{r}74,890 \\
8,240 \\
13,750 \\
8,090 \\
170,050\end{array}$ & $\begin{array}{r}21,725 \\
1,800 \\
2,950 \\
3,560 \\
33,500\end{array}$ & $\begin{array}{r}5,755 \\
315 \\
1,225 \\
305 \\
5,240\end{array}$ \\
\hline $\begin{array}{l}\text { Douglas.... } \\
\text { Finney } \\
\text { Franklin } \\
\text { Geary } \\
\text { Gove.......... }\end{array}$ & $\begin{array}{r}60 \\
8 \\
11 \\
5 \\
8\end{array}$ & $\begin{array}{r}5,113 \\
2,288 \\
775 \\
427 \\
4,089\end{array}$ & $\begin{array}{r}440,810 \\
70,300 \\
59,610 \\
28,000 \\
125,070\end{array}$ & $\begin{array}{r}348,800 \\
56,900 \\
52,110 \\
22,850 \\
108,570\end{array}$ & $\begin{array}{r}92,010 \\
13,400 \\
7,500 \\
-\quad 5,150 \\
16,500\end{array}$ & $\begin{array}{r}17,500 \\
5,850 \\
770 \\
2,425 \\
7,775\end{array}$ \\
\hline $\begin{array}{l}\text { Graham } \\
\text { Hodgeman } \\
\text { Jackson } \\
\text { Jefferson } \\
\text { Johnson. }\end{array}$ & $\begin{array}{l}77 \\
11 \\
12 \\
25 \\
22\end{array}$ & $\begin{array}{r}18,198 \\
1,878 \\
1,514 \\
3,265 \\
1,403\end{array}$ & $\begin{array}{r}420,105 \\
53,425 \\
70,200 \\
174,435 \\
149,900\end{array}$ & $\begin{array}{r}366,230 \\
47,375 \\
58,225 \\
142,735 \\
129,805\end{array}$ & $\begin{array}{r}53,875 \\
6,050 \\
11,975 \\
31,700 \\
20,095\end{array}$ & $\begin{array}{r}29,015 \\
1,930 \\
2,650 \\
7,055 \\
1,990\end{array}$ \\
\hline $\begin{array}{l}\text { Labette } \\
\text { Leavenworth } \\
\text { Linn } \\
\text { Logan } \\
\text { Lyon }\end{array}$ & $\begin{array}{r}11 \\
37 \\
6 \\
31 \\
16\end{array}$ & $\begin{array}{r}700 \\
2,645 \\
325 \\
22,460 \\
1,117\end{array}$ & $\begin{array}{r}34,830 \\
152,345 \\
13,900 \\
236,430 \\
84,490\end{array}$ & $\begin{array}{r}26,840 \\
132,770 \\
11,400 \\
211,555 \\
62,140\end{array}$ & $\begin{array}{r}7,990 \\
19,575 \\
2,500 \\
24,875 \\
22,350\end{array}$ & $\begin{array}{r}1,430 \\
2,810 \\
60 \\
13,780 \\
5,555\end{array}$ \\
\hline $\begin{array}{l}\text { Marshall. } \\
\text { Meade } \\
\text { Miami... } \\
\text { Montgomery } \\
\text { Morris....... }\end{array}$ & $\begin{array}{r}9 \\
6 \\
7 \\
105 \\
14\end{array}$ & $\begin{array}{r}2,075 \\
4,060 \\
710 \\
6,661 \\
800\end{array}$ & $\begin{array}{r}114,430 \\
148,600 \\
41,800 \\
259,510 \\
31,850\end{array}$ & $\begin{array}{r}95,530 \\
136,400 \\
33,200 \\
198,020 \\
21,800\end{array}$ & $\begin{array}{r}18,900 \\
12,200 \\
8,600 \\
61,490 \\
10,050\end{array}$ & $\begin{array}{r}2,590 \\
19,850 \\
675 \\
10,200 \\
1,545\end{array}$ \\
\hline 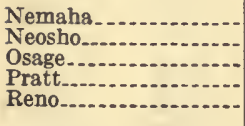 & $\begin{array}{r}7 \\
6 \\
11 \\
13 \\
8\end{array}$ & $\begin{array}{r}986 \\
1,232 \\
890 \\
3,270 \\
572\end{array}$ & $\begin{array}{r}77,850 \\
50.560 \\
36,550 \\
209,600 \\
27,600\end{array}$ & $\begin{array}{r}68,600 \\
41,260 \\
25,600 \\
191,650 \\
22,150\end{array}$ & $\begin{array}{r}9,250 \\
9,300 \\
10,950 \\
17,950 \\
5,450\end{array}$ & $\begin{array}{r}3,480 \\
3,400 \\
1,770 \\
16,950 \\
1,210\end{array}$ \\
\hline 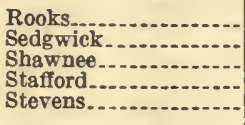 & $\begin{array}{r}5 \\
10 \\
40 \\
8 \\
20\end{array}$ & $\begin{array}{l}1,140 \\
1,073 \\
2,975 \\
1,730 \\
7,688\end{array}$ & $\begin{array}{r}27,900 \\
90,200 \\
361,430 \\
114,730 \\
143,760\end{array}$ & $\begin{array}{r}24,200 \\
85,230 \\
288,980 \\
100,200 \\
125,010\end{array}$ & $\begin{array}{r}3,700 \\
4,970 \\
72,450 \\
14,530 \\
18,750\end{array}$ & $\begin{array}{l}4,250 \\
2,225 \\
8,605 \\
8,565 \\
9,600\end{array}$ \\
\hline \multirow[t]{2}{*}{$\begin{array}{l}\text { Sumner } \\
\text { Trego } \\
\text { Wabaunsee. } \\
\text { Wyandotte } \\
\text { Other counties... }\end{array}$} & $\begin{array}{r}5 \\
5 \\
41 \\
73 \\
70\end{array}$ & $\begin{array}{r}1,088 \\
7,460 \\
5,347 \\
1,976 \\
15,018\end{array}$ & $\begin{array}{r}84,500 \\
51,650 \\
271,360 \\
458,100 \\
545,515\end{array}$ & $\begin{array}{r}77,600 \\
46,300 \\
206,410 \\
371,320 \\
464,430\end{array}$ & $\begin{array}{r}6,900 \\
5,350 \\
64,950 \\
86,780 \\
81,0 \$ 5\end{array}$ & $\begin{array}{r}3,500 \\
1,125 \\
12,750 \\
9,140 \\
37,215\end{array}$ \\
\hline & \multicolumn{6}{|c|}{ KENTUCKY } \\
\hline Total... & 9,104 & 341,838 & $\$ 16,157,593$ & $\$ 11,825,769$ & $84,881,824$ & 8605,430 \\
\hline $\begin{array}{l}\text { Adair } \\
\text { Allen } \\
\text { Anderson } \\
\text { Ballard } \\
\text { Barren }\end{array}$ & $\begin{array}{r}115 \\
53 \\
8 \\
131 \\
324\end{array}$ & $\begin{array}{r}5,282 \\
2,021 \\
123 \\
5,361 \\
10,897\end{array}$ & $\begin{array}{r}97,585 \\
42,945 \\
9,415 \\
158,600 \\
468,360\end{array}$ & $\begin{array}{r}68,164 \\
27,530 \\
6,645 \\
116,120 \\
326,140\end{array}$ & $\begin{array}{r}29,421 \\
15,415 \\
2,770 \\
42,480 \\
142,220\end{array}$ & $\begin{array}{r}3,656 \\
985 \\
714 \\
8,133 \\
15,612\end{array}$ \\
\hline $\begin{array}{l}\text { Bath } \\
\text { Bell } \\
\text { Boone- } \\
\text { Bourbon } \\
\text { Boyle }\end{array}$ & $\begin{array}{r}53 \\
5 \\
41 \\
171 \\
92\end{array}$ & $\begin{array}{l}1,125 \\
71 \\
3,901 \\
2,334 \\
1,623\end{array}$ & $\begin{array}{r}109,410 \\
7,600 \\
203,750 \\
365,795 \\
110,715\end{array}$ & $\begin{array}{r}66,110 \\
2,650 \\
138,225 \\
247,610 \\
77,490\end{array}$ & $\begin{array}{r}43,300 \\
4,950 \\
65,525 \\
118,185 \\
33,225\end{array}$ & $\begin{array}{r}3,490 \\
250 \\
6,540 \\
16,988 \\
3,290\end{array}$ \\
\hline
\end{tabular}


Table 38.-Farms Operated by Negroes-Number, Acreage, and Value of Specified Classes of Farm Property, by States and Counties, 1930Continued

\begin{tabular}{|c|c|c|c|c|c|c|}
\hline \multirow{2}{*}{ STATE AND COUNTY } & \multirow{2}{*}{$\begin{array}{l}\text { Number } \\
\text { of farms }\end{array}$} & \multirow{2}{*}{$\begin{array}{l}\text { Land in } \\
\text { farms } \\
\text { (acres) }\end{array}$} & \multicolumn{3}{|c|}{ VALUE OF LAND AND BIILDINGS } & \multirow{2}{*}{$\begin{array}{l}\text { Value of } \\
\text { imple- } \\
\text { ments and } \\
\text { machinery }\end{array}$} \\
\hline & & & Total & Land alone & Buildings & \\
\hline & \multicolumn{6}{|c|}{ KENTUCKY-continued } \\
\hline $\begin{array}{l}\text { Bracken } \\
\text { Breathitt-. } \\
\text { Breckinridge } \\
\text { Bullitt... } \\
\text { Butler }\end{array}$ & \begin{tabular}{r|}
7 \\
8 \\
47 \\
36 \\
28
\end{tabular} & $\begin{array}{r}197 \\
214 \\
3,751 \\
2,444 \\
1,559\end{array}$ & $\begin{array}{r}\$ 21,000 \\
9,000 \\
67,950 \\
91,538 \\
18,925\end{array}$ & $\begin{array}{r}\$ 10,700 \\
6,700 \\
34,175 \\
70,508 \\
12,470\end{array}$ & $\begin{array}{r}\$ 10,300 \\
2,300 \\
33,775 \\
21,030 \\
6,455\end{array}$ & $\begin{array}{r}\$ 735 \\
235 \\
1,743 \\
1,953 \\
896\end{array}$ \\
\hline $\begin{array}{l}\text { Caldwell } \\
\text { Calloway } \\
\text { Carlisle } \\
\text { Carroll } \\
\text { Casey }\end{array}$ & $\begin{array}{r}80 \\
39 \\
9 \\
18 \\
22\end{array}$ & $\begin{array}{r}4,363 \\
2,486 \\
421 \\
523 \\
659\end{array}$ & $\begin{array}{r}100,170 \\
55,635 \\
13,850 \\
38,850 \\
13,550\end{array}$ & $\begin{array}{r}72,895 \\
37,985 \\
9,185 \\
28,250 \\
10,000\end{array}$ & $\begin{array}{r}27,275 \\
17,650 \\
4,665 \\
10,600 \\
3,550\end{array}$ & $\begin{array}{r}2,990 \\
1,695 \\
308 \\
1,010 \\
1,025\end{array}$ \\
\hline $\begin{array}{l}\text { Christian } \\
\text { Clark } \\
\text { Clay } \\
\text { Clinton } \\
\text { Crittenden.... }\end{array}$ & $\begin{array}{r}677 \\
84 \\
39 \\
14 \\
14\end{array}$ & $\begin{array}{r}35,485 \\
1,916 \\
1,288 \\
601 \\
425\end{array}$ & $\begin{array}{r}1,127,555 \\
123,405 \\
31,950 \\
6,615 \\
9,400\end{array}$ & $\begin{array}{r}807,115 \\
77,510 \\
19,955 \\
5,815 \\
6,010\end{array}$ & $\begin{array}{r}320,440 \\
45,895 \\
11,995 \\
800 \\
3,390\end{array}$ & $\begin{array}{r}53,033 \\
4,835 \\
741 \\
260 \\
420\end{array}$ \\
\hline 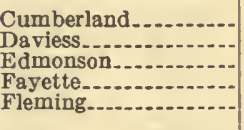 & $\begin{array}{r}98 \\
204 \\
30 \\
175 \\
41\end{array}$ & $\begin{array}{r}3,437 \\
6,484 \\
1,943 \\
4,950 \\
807\end{array}$ & $\begin{array}{r}120,500 \\
342,485 \\
38,450 \\
1,038,735 \\
70,590\end{array}$ & $\begin{array}{r}89,785 \\
240,820 \\
28,645 \\
744,105 \\
50,605\end{array}$ & $\begin{array}{r}30,715 \\
101,665 \\
9,805 \\
294,630 \\
19,985\end{array}$ & $\begin{array}{r}4,170 \\
9,827 \\
1,730 \\
32,170 \\
1,918\end{array}$ \\
\hline $\begin{array}{l}\text { Floyd } \\
\text { Franklin. } \\
\text { Fulton } \\
\text { Gallatin } \\
\text { Garrard }\end{array}$ & $\begin{array}{r}13 \\
20 \\
313 \\
18 \\
208\end{array}$ & $\begin{array}{r}564 \\
651 \\
10,722 \\
708 \\
4,526\end{array}$ & $\begin{array}{r}18,000 \\
43,115 \\
953,915 \\
27,140 \\
346,995\end{array}$ & $\begin{array}{r}12,425 \\
32,810 \\
797,095 \\
16,765 \\
228,110\end{array}$ & $\begin{array}{r}5,575 \\
10,305 \\
156,820 \\
10,375 \\
118,885\end{array}$ & $\begin{array}{r}90 \\
1,575 \\
29,455 \\
140 \\
15,113\end{array}$ \\
\hline $\begin{array}{l}\text { Grant_........ } \\
\text { Graves....... } \\
\text { Green } \\
\text { Greenup....... } \\
\text { Hancock..... }\end{array}$ & $\begin{array}{r}8 \\
143 \\
184 \\
5 \\
15\end{array}$ & $\begin{array}{r}52 \\
6,087 \\
6,473 \\
148 \\
344\end{array}$ & $\begin{array}{r}6,500 \\
219,475 \\
185,405 \\
9,400 \\
35,055\end{array}$ & $\begin{array}{r}5,360 \\
162,095 \\
137,660 \\
7,400 \\
26,355\end{array}$ & $\begin{array}{r}1,140 \\
57,380 \\
47,745 \\
2,000 \\
8,700\end{array}$ & $\begin{array}{r}50 \\
6,703 \\
9,205 \\
117 \\
3,035\end{array}$ \\
\hline $\begin{array}{l}\text { Hardin } \\
\text { Harlan } \\
\text { Harrison } \\
\text { Hart } \\
\text { Henderson..... }\end{array}$ & $\begin{array}{r}48 \\
7 \\
58 \\
190 \\
312\end{array}$ & $\begin{array}{r}2,373 \\
417 \\
2,250 \\
5,590 \\
13,052\end{array}$ & $\begin{array}{r}87,675 \\
10,400 \\
164,039 \\
221,605 \\
610,475\end{array}$ & $\begin{array}{r}56,445 \\
8,250 \\
112,389 \\
149,450 \\
446,000\end{array}$ & $\begin{array}{r}31,230 \\
2,150 \\
51,650 \\
72,155 \\
164,475\end{array}$ & $\begin{array}{r}3,365 \\
43 \\
8,103 \\
10,955 \\
21,095\end{array}$ \\
\hline $\begin{array}{l}\text { Henry } \\
\text { Hickman } \\
\text { Hopkins } \\
\text { Jefferson } \\
\text { Jessamine }\end{array}$ & $\begin{array}{r}79 \\
87 \\
70 \\
60 \\
124\end{array}$ & $\begin{array}{l}1,650 \\
4,139 \\
2,448 \\
1,720 \\
3,167\end{array}$ & $\begin{array}{l}175,790 \\
133,270 \\
115,645 \\
249,900 \\
365,640\end{array}$ & $\begin{array}{r}101,615 \\
101,395 \\
78,695 \\
167,700 \\
243,940\end{array}$ & $\begin{array}{r}74,175 \\
31,875 \\
36,950 \\
82,200 \\
121,700\end{array}$ & $\begin{array}{r}4,120 \\
4,700 \\
4,650 \\
5,841 \\
14,670\end{array}$ \\
\hline $\begin{array}{l}\text { Kenton } \\
\text { Knott } \\
\text { Knox } \\
\text { Larue } \\
\text { Laurel }\end{array}$ & $\begin{array}{l}13 \\
17 \\
27 \\
31 \\
16\end{array}$ & $\begin{array}{r}630 \\
580 \\
578 \\
1,323 \\
217\end{array}$ & $\begin{array}{l}37,200 \\
18,060 \\
36,300 \\
44,465 \\
21,975\end{array}$ & $\begin{array}{l}24,600 \\
12,810 \\
23,550 \\
23,565 \\
16,485\end{array}$ & $\begin{array}{r}12,600 \\
5,250 \\
12,750 \\
20,900 \\
5,490\end{array}$ & $\begin{array}{r}1,175 \\
106 \\
437 \\
2,090 \\
284\end{array}$ \\
\hline $\begin{array}{l}\text { Lee } \\
\text { Lewis } \\
\text { Lincoln } \\
\text { Livingston } \\
\text { Logan }\end{array}$ & $\begin{array}{r}12 \\
10 \\
148 \\
20 \\
373\end{array}$ & $\begin{array}{r}228 \\
927 \\
3,023 \\
1,360 \\
13,682\end{array}$ & $\begin{array}{r}7,070 \\
10,250 \\
148,005 \\
23,070 \\
573,808\end{array}$ & $\begin{array}{r}4,420 \\
5,500 \\
104,819 \\
17,320 \\
375,063\end{array}$ & $\begin{array}{r}2,650 \\
4,750 \\
43,186 \\
5,750 \\
198,745\end{array}$ & $\begin{array}{r}45 \\
705 \\
5,809 \\
1,776 \\
19,137\end{array}$ \\
\hline $\begin{array}{l}\text { Lyon } \\
\text { MeCracken } \\
\text { MeLean } \\
\text { Madison } \\
\text { Magoffin }\end{array}$ & $\begin{array}{r}93 \\
250 \\
24 \\
419 \\
5\end{array}$ & $\begin{array}{r}4,148 \\
5,133 \\
1,211 \\
12,020 \\
408\end{array}$ & $\begin{array}{r}70,827 \\
444,061 \\
43,810 \\
797,765 \\
10,200\end{array}$ & $\begin{array}{r}53,906 \\
281,875 \\
35,685 \\
577,550 \\
8,900\end{array}$ & $\begin{array}{r}16,921 \\
162,186 \\
8,125 \\
220,215 \\
1,300\end{array}$ & $\begin{array}{r}1,930 \\
25,550 \\
3,060 \\
26,502 \\
140\end{array}$ \\
\hline $\begin{array}{l}\text { Marion } \\
\text { Mason } \\
\text { Meade- } \\
\text { Mercer } \\
\text { Metcalfe... } \\
\text { Met }\end{array}$ & $\begin{array}{r}90 \\
85 \\
55 \\
53 \\
102\end{array}$ & $\begin{array}{l}3,927 \\
2,770 \\
6,213 \\
1,805 \\
3,637\end{array}$ & $\begin{array}{r}176,250 \\
245,360 \\
102,553 \\
127,400 \\
91,375\end{array}$ & $\begin{array}{r}120,810 \\
176,260 \\
69,643 \\
79,600 \\
60,550\end{array}$ & $\begin{array}{l}55,440 \\
69,100 \\
32,910 \\
47,800 \\
30,825\end{array}$ & $\begin{array}{r}3,188 \\
11,260 \\
5,660 \\
3,695 \\
4,588\end{array}$ \\
\hline $\begin{array}{l}\text { Monroe } \\
\text { Montgomery } \\
\text { Muhlenberg- } \\
\text { Nelson } \\
\text { Nicholas. }\end{array}$ & \begin{tabular}{r||}
53 \\
67 \\
53 \\
110 \\
45
\end{tabular} & $\begin{array}{l}1,955 \\
1,967 \\
3,247 \\
4,372 \\
693\end{array}$ & $\begin{array}{r}41,765 \\
186,795 \\
63,775 \\
254,205 \\
60,690\end{array}$ & $\begin{array}{r}28,215 \\
129,745 \\
41,560 \\
165,100 \\
36,390\end{array}$ & $\begin{array}{l}13,550 \\
57,050 \\
22,215 \\
89,105 \\
24,300\end{array}$ & $\begin{array}{l}1,200 \\
6,140 \\
3,112 \\
9,608 \\
5,025\end{array}$ \\
\hline
\end{tabular}


Table 38.-Farms Operated by Negroes-Number, Acreage, and Value of Specified Classes of Farm Property, by States and Counties, 1930Continued

\begin{tabular}{|c|c|c|c|c|c|c|}
\hline \multirow{2}{*}{ STATE AND COUNTX } & \multirow{2}{*}{$\begin{array}{l}\text { Number } \\
\text { of farms }\end{array}$} & \multirow{2}{*}{$\begin{array}{l}\text { Land in } \\
\text { farms } \\
\text { (acres) }\end{array}$} & \multicolumn{3}{|c|}{ VALUE OF LAND AND BUIYDINGS } & \multirow{2}{*}{$\begin{array}{l}\text { Value of } \\
\text { imple- } \\
\text { ments and } \\
\text { machinery }\end{array}$} \\
\hline & & & Total & Land alone & Buildings & \\
\hline & \multicolumn{6}{|c|}{ KENTUCKY-continued } \\
\hline $\begin{array}{l}\text { Ohio } \\
\text { Oldham } \\
\text { Owen } \\
\text { Owsley } \\
\text { Pendleton }\end{array}$ & $\begin{array}{r}35 \\
, \quad 15 \\
88 \\
6 \\
17\end{array}$ & $\begin{array}{r}2,263 \\
831 \\
3,055 \\
276 \\
669\end{array}$ & $\begin{array}{r}\$ 39,410 \\
52,200 \\
141,294 \\
4,650 \\
25,840\end{array}$ & $\begin{array}{r}\$ 26,560 \\
30,725 \\
97,474 \\
3,775 \\
20,755\end{array}$ & $\begin{array}{r}\$ 12,850 \\
21,475 \\
43,820 \\
875 \\
5,085\end{array}$ & $\begin{array}{r}\$ 1,315 \\
2,785 \\
4,226 \\
27 \\
625\end{array}$ \\
\hline $\begin{array}{l}\text { Perry } \\
\text { Pike } \\
\text { Powell } \\
\text { Pulaski. } \\
\text { Robertson }\end{array}$ & $\begin{array}{r}44 \\
6 \\
27 \\
38 \\
5\end{array}$ & $\begin{array}{r}1,790 \\
1,157 \\
1,354 \\
1,093 \\
322\end{array}$ & $\begin{array}{l}55,365 \\
21,600 \\
39,350 \\
42,075 \\
18,300\end{array}$ & $\begin{array}{l}21,415 \\
16,725 \\
23,675 \\
24,925 \\
15,000\end{array}$ & $\begin{array}{r}33,950 \\
4,875 \\
15,675 \\
17,150 \\
3,300\end{array}$ & $\begin{array}{r}1,420 \\
95 \\
1,350 \\
1,465 \\
525\end{array}$ \\
\hline 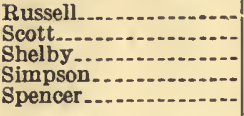 & $\begin{array}{r}23 \\
119 \\
120 \\
173 \\
35\end{array}$ & $\begin{array}{l}1,856 \\
2,276 \\
2,917 \\
8,325 \\
1,312\end{array}$ & $\begin{array}{r}24,375 \\
282,060 \\
255,016 \\
294,625 \\
84,955\end{array}$ & $\begin{array}{r}19,330 \\
187,515 \\
158,536 \\
209,505 \\
57,880\end{array}$ & $\begin{array}{r}5,045 \\
94,545 \\
96,480 \\
85,120 \\
27,075\end{array}$ & $\begin{array}{r}450 \\
12,615 \\
9,321 \\
13,025 \\
3,844\end{array}$ \\
\hline $\begin{array}{l}\text { Taylor } \\
\text { Todd } \\
\text { Trigg } \\
\text { Trimble.... }\end{array}$ & $\begin{array}{r}122 \\
369 \\
270 \\
6\end{array}$ & $\begin{array}{r}4,444 \\
15,099 \\
16,472 \\
522\end{array}$ & $\begin{array}{r}153,035 \\
480,380 \\
349,272 \\
22,300\end{array}$ & $\begin{array}{r}113,390 \\
368,550 \\
214,182 \\
16,800\end{array}$ & $\begin{array}{r}39,645 \\
111,830 \\
135,090 \\
5,500\end{array}$ & $\begin{array}{r}6,585 \\
23,155 \\
19,496 \\
990\end{array}$ \\
\hline $\begin{array}{l}\text { Union } \\
\text { Warren.......... } \\
\text { Washington. } \\
\text { Wayne...... }\end{array}$ & $\begin{array}{r}42 \\
308 \\
155 \\
54\end{array}$ & $\begin{array}{r}1,271 \\
10,238 \\
4,850 \\
1,953\end{array}$ & $\begin{array}{r}52,425 \\
474,370 \\
261,655 \\
50,300\end{array}$ & $\begin{array}{r}36,980 \\
356,820 \\
189,130 \\
35,185\end{array}$ & $\begin{array}{r}15,445 \\
117,550 \\
72,525 \\
15,115\end{array}$ & $\begin{array}{r}2,320 \\
14,867 \\
5,695 \\
1,336\end{array}$ \\
\hline \multirow[t]{2}{*}{$\begin{array}{l}\text { Webster } \\
\text { Whitley } \\
\text { Woodford... } \\
\text { Other counties....... }\end{array}$} & $\begin{array}{r}87 \\
10 \\
111 \\
23\end{array}$ & $\begin{array}{l}4,226 \\
281 \\
2,067 \\
1,083\end{array}$ & $\begin{array}{r}135,830 \\
8,175 \\
232,135 \\
25,800\end{array}$ & $\begin{array}{r}90,330 \\
5,575 \\
158,900 \\
20,340\end{array}$ & $\begin{array}{r}45,500 \\
2,600 \\
73,235 \\
5,460\end{array}$ & $\begin{array}{r}4,947 \\
110 \\
5,237 \\
1,005\end{array}$ \\
\hline & \multicolumn{6}{|c|}{ LOUISLANA（PARISH） } \\
\hline Total... & 73,734 & $2,313,338$ & $\$ 108,688,818$ & $\$ 88,432,377$ & $\$ 22,236,441$ & $\$ 4,870,550$ \\
\hline $\begin{array}{l}\text { Acadia } \\
\text { Allen } \\
\text { Ascension } \\
\text { Assumption } \\
\text { A voyelles. }\end{array}$ & $\begin{array}{r}494 \\
116 \\
306 \\
20 \\
1,840\end{array}$ & $\begin{array}{r}14,778 \\
3,801 \\
6,840 \\
416 \\
35,691\end{array}$ & $\begin{array}{r}852,951 \\
130,120 \\
348,307 \\
30,055 \\
2,555,854\end{array}$ & $\begin{array}{r}688,661 \\
90,395 \\
233,822 \\
17,890 \\
2,052,032\end{array}$ & $\begin{array}{r}164,290 \\
39,725 \\
114,485 \\
12,165 \\
503,822\end{array}$ & $\begin{array}{r}51,342 \\
7,038 \\
12,969 \\
729 \\
74,923\end{array}$ \\
\hline $\begin{array}{l}\text { Beauregard. } \\
\text { Bienville } \\
\text { Bossier } \\
\text { Caddo } \\
\text { Calcasieu. }\end{array}$ & $\begin{array}{r}111 \\
1,858 \\
3,874 \\
6,154 \\
300\end{array}$ & $\begin{array}{r}3,870 \\
86,692 \\
111,838 \\
177,438 \\
14,796\end{array}$ & $\begin{array}{r}165,704 \\
2,279,860 \\
6,492,333 \\
12,104,127 \\
667,345\end{array}$ & $\begin{array}{r}125,579 \\
1,625,550 \\
5,628,283 \\
10,519,859 \\
519,425\end{array}$ & $\begin{array}{r}40,125 \\
654,310 \\
864,050 \\
1,584,268 \\
147,920\end{array}$ & $\begin{array}{r}7,650 \\
135,049 \\
202,927 \\
438,906 \\
39,361\end{array}$ \\
\hline $\begin{array}{l}\text { Caldwell } \\
\text { Cameron } \\
\text { Cataboula } \\
\text { Claiborne } \\
\text { Concordis }\end{array}$ & $\begin{array}{r}319 \\
85 \\
914 \\
3,233 \\
1,543\end{array}$ & $\begin{array}{r}9,471 \\
3,220 \\
22,359 \\
185,500 \\
26,992\end{array}$ & $\begin{array}{r}483,448 \\
160,950 \\
1,517,720 \\
3,793,476 \\
1,574,111\end{array}$ & $\begin{array}{r}388,448 \\
106,380 \\
1,242,715 \\
2,882,712 \\
1,215,211\end{array}$ & $\begin{array}{r}95,000 \\
54,570 \\
275,005 \\
910,764 \\
358,900\end{array}$ & $\begin{array}{r}19,130 \\
3,958 \\
58,890 \\
172,903 \\
53,944\end{array}$ \\
\hline $\begin{array}{l}\text { De Soto } \\
\text { East Baton Rouge... } \\
\text { East Carroll } \\
\text { East Feliciana } \\
\text { Evangeline......... }\end{array}$ & $\begin{array}{r}3,752 \\
1,367 \\
2,881 \\
1,933 \\
886\end{array}$ & $\begin{array}{r}141,115 \\
34,622 \\
53,369 \\
67,666 \\
27,755\end{array}$ & $\begin{array}{l}2,981,837 \\
2,054,075 \\
3,957,712 \\
1,322,635 \\
1,304,560\end{array}$ & $\begin{array}{r}2,227,624 \\
1,592,630 \\
3,119,372 \\
926,843 \\
866,790\end{array}$ & $\begin{array}{l}754,213 \\
461,445 \\
838,340 \\
395,792 \\
437,770\end{array}$ & $\begin{array}{r}171,264 \\
73,616 \\
229,597 \\
103,762 \\
81,011\end{array}$ \\
\hline $\begin{array}{l}\text { Franklin } \\
\text { Grant } \\
\text { Iberia } \\
\text { Iberville. }\end{array}$ & $\begin{array}{r}2,521 \\
574 \\
333 \\
250 \\
511\end{array}$ & $\begin{array}{r}59,374 \\
12,331 \\
17,393 \\
7,566 \\
28,817\end{array}$ & $\begin{array}{r}3,946,870 \\
654,783 \\
1,110,131 \\
362,788 \\
473,061\end{array}$ & $\begin{array}{r}3,304,010 \\
535,088 \\
909,706 \\
264,158 \\
331,243\end{array}$ & $\begin{array}{r}642,860 \\
119,695 \\
200,425 \\
98,630 \\
141,818\end{array}$ & $\begin{array}{r}180,211 \\
25,400 \\
33,013 \\
16,217 \\
26,087\end{array}$ \\
\hline $\begin{array}{l}\text { Jefferson } \\
\text { Jefferson Davis. } \\
\text { Lafayette. } \\
\text { Lafourche. } \\
\text { La Salle }\end{array}$ & $\begin{array}{r}15 \\
317 \\
1,026 \\
17 \\
61\end{array}$ & $\begin{array}{r}199 \\
11,873 \\
40,468 \\
779 \\
2,094\end{array}$ & $\begin{array}{r}29,080 \\
505,365 \\
3,410,150 \\
44,025 \\
67,900\end{array}$ & $\begin{array}{r}23,205 \\
377,280 \\
3,017,647 \\
32,720 \\
31,200\end{array}$ & $\begin{array}{r}5,875 \\
128,085 \\
392,503 \\
11,305 \\
36,700\end{array}$ & $\begin{array}{r}1,880 \\
33,051 \\
87,256 \\
1,971 \\
2,736\end{array}$ \\
\hline
\end{tabular}


Table 38. - Farms Operated by Negroes-Number, Acreage, and Value of Specified Classes of Farm Property, by States and Counties, $1930-$ Continued

\begin{tabular}{|c|c|c|c|c|c|c|}
\hline \multirow{2}{*}{ STATE AND COUNTY } & \multirow{2}{*}{$\begin{array}{l}\text { Number } \\
\text { of farms }\end{array}$} & \multirow{2}{*}{$\begin{array}{l}\text { Land in } \\
\text { farms } \\
\text { (acres) }\end{array}$} & \multicolumn{3}{|c|}{ VALUE OF LAND AND BUILDINGS } & \multirow{2}{*}{$\begin{array}{l}\text { Value of } \\
\text { imple- } \\
\text { ments and } \\
\text { machinery }\end{array}$} \\
\hline & & & Total & Land alone & Buildings & \\
\hline & \multicolumn{6}{|c|}{ LOUISIANA (PARISH)—continued } \\
\hline $\begin{array}{l}\text { Lincoln } \\
\text { Livingston. } \\
\text { Madison } \\
\text { Morehouse-. } \\
\text { Natchitoches... }\end{array}$ & $\begin{array}{r}1,541 \\
297 \\
1,795 \\
2,815 \\
3,362\end{array}$ & $\begin{array}{r}83,557 \\
4,202 \\
35,245 \\
75,662 \\
92,553\end{array}$ & $\begin{array}{r}\$ 2,405,633 \\
241,015 \\
2,321,293 \\
4,235,395 \\
4,993,742\end{array}$ & $\begin{array}{r}\$ 1,833,210 \\
180,265 \\
1,637,043 \\
3,319,801 \\
4,088,022\end{array}$ & $\begin{array}{r}\$ 572,423 \\
60,750 \\
684,250 \\
915,594 \\
905,720\end{array}$ & $\begin{array}{r}\$ 97,149 \\
14,590 \\
180,281 \\
216,708 \\
208,409\end{array}$ \\
\hline $\begin{array}{l}\text { Orleans } \\
\text { Ouachita. } \\
\text { Plaquemines } \\
\text { Pointe Coupee. } \\
\text { Rapldes.......... }\end{array}$ & $\begin{array}{r}12 \\
1,384 \\
127 \\
1,679 \\
1,802\end{array}$ & $\begin{array}{r}67 \\
43,134 \\
4,424 \\
43,371 \\
40,511\end{array}$ & $\begin{array}{r}18,820 \\
2,371,191 \\
314,725 \\
2,236,209 \\
3,423,726\end{array}$ & $\begin{array}{r}11,820 \\
1,955,558 \\
241,780 \\
1,640,952 \\
2,860,046\end{array}$ & $\begin{array}{r}7,000 \\
415,633 \\
72,945 \\
595,257 \\
563,680\end{array}$ & $\begin{array}{r}800 \\
98,408 \\
13,606 \\
117,630 \\
114,561\end{array}$ \\
\hline $\begin{array}{l}\text { Red River } \\
\text { Rlchland } \\
\text { Sabine } \\
\text { St. Bernard. } \\
\text { St. Charles... }\end{array}$ & $\begin{array}{r}1,750 \\
2,934 \\
507 \\
24 \\
48\end{array}$ & $\begin{array}{r}45,192 \\
73,235 \\
21,550 \\
415 \\
2,048\end{array}$ & $\begin{array}{r}2,343,831 \\
4,392,893 \\
362,080 \\
30,900 \\
110,340\end{array}$ & $\begin{array}{r}1,896,055 \\
3,678,598 \\
263,602 \\
21,500 \\
93,905\end{array}$ & $\begin{array}{r}447,776 \\
714,295 \\
98,478 \\
9,400 \\
16,435\end{array}$ & $\begin{array}{r}92,768 \\
270,455 \\
22,693 \\
3,207 \\
9,245\end{array}$ \\
\hline $\begin{array}{l}\text { St. Helena } \\
\text { St. James } \\
\text { St. John the Baptist.- } \\
\text { St. Landry } \\
\text { St. Martin }\end{array}$ & $\begin{array}{r}840 \\
94 \\
41 \\
3,736 \\
751\end{array}$ & $\begin{array}{r}29,849 \\
5,627 \\
2,432 \\
118,446 \\
31,688\end{array}$ & $\begin{array}{r}685,220 \\
243,825 \\
138,825 \\
7,429,622 \\
2,309,777\end{array}$ & $\begin{array}{r}381,370 \\
192,745 \\
95,375 \\
5,905,922 \\
1,922,690\end{array}$ & $\begin{array}{r}303,850 \\
51,080 \\
43,450 \\
1,523,700 \\
387,087\end{array}$ & $\begin{array}{r}56,140 \\
5,497 \\
7,730 \\
277,264 \\
75,884\end{array}$ \\
\hline $\begin{array}{l}\text { St. Mary } \\
\text { St. Tammany } \\
\text { Tangipaboa } \\
\text { Tensas................... } \\
\text { Terrebonne........ }\end{array}$ & $\begin{array}{r}170 \\
233 \\
1,167 \\
2,492 \\
101\end{array}$ & $\begin{array}{r}5,916 \\
16,529 \\
22,023 \\
44,984 \\
3,971\end{array}$ & $\begin{array}{r}286,267 \\
656,465 \\
1,355,371 \\
2,638,666 \\
164,169\end{array}$ & $\begin{array}{r}214,530 \\
425,940 \\
865,306 \\
2,031,424 \\
117,609\end{array}$ & $\begin{array}{r}71,737 \\
230,525 \\
490,065 \\
607,242 \\
46,560\end{array}$ & $\begin{array}{r}14,374 \\
28,952 \\
63,163 \\
97,088 \\
9,297\end{array}$ \\
\hline $\begin{array}{l}\text { Union } \\
\text { Vermilion } \\
\text { Vernon } \\
\text { Washington } \\
\text { Webster }\end{array}$ & $\begin{array}{r}1,082 \\
275 \\
93 \\
743 \\
1,904\end{array}$ & $\begin{array}{r}57,360 \\
14,223 \\
2,960 \\
31,350 \\
83,264\end{array}$ & $\begin{array}{r}1,146,396 \\
736,510 \\
66,215 \\
835,352 \\
2,429,646\end{array}$ & $\begin{array}{r}864,775 \\
643,845 \\
38,090 \\
539,819 \\
1,811,882\end{array}$ & $\begin{array}{r}281,621 \\
92,665 \\
28,125 \\
295,533 \\
617,764\end{array}$ & $\begin{array}{r}58,219 \\
38,280 \\
4,119 \\
59,795 \\
124,827\end{array}$ \\
\hline \multirow[t]{2}{*}{$\begin{array}{l}\text { West Baton Rouge } \\
\text { West Carroll } \\
\text { West Feliciana.... } \\
\text { Winn }\end{array}$} & $\begin{array}{r}227 \\
596 \\
1,173 \\
328\end{array}$ & $\begin{array}{r}5,843 \\
13,807 \\
33,605 \\
15,172\end{array}$ & $\begin{array}{l}317,274 \\
950,780 \\
798,597 \\
296,715\end{array}$ & $\begin{array}{l}228,199 \\
796,752 \\
540,109 \\
197,360\end{array}$ & $\begin{array}{r}89,075 \\
154,028 \\
258,488 \\
99,355\end{array}$ & $\begin{array}{l}17,444 \\
44,140 \\
57,809 \\
23,221\end{array}$ \\
\hline & \multicolumn{6}{|c|}{ MAINE } \\
\hline Total & 15 & 818 & $\$ 41,400$ & $\$ 15,700$ & $\$ 25,700$ & $\$ 6,075$ \\
\hline \multirow[t]{2}{*}{$\begin{array}{l}\text { Penobscot } \\
\text { Other counties........... }\end{array}$} & $\begin{array}{l}6 \\
9\end{array}$ & $\begin{array}{l}402 \\
416\end{array}$ & $\begin{array}{l}14,700 \\
26,700\end{array}$ & $\begin{array}{r}4,000 \\
11,700\end{array}$ & $\begin{array}{l}10,700 \\
15,000\end{array}$ & $\begin{array}{l}2,900 \\
3,175\end{array}$ \\
\hline & \multicolumn{6}{|c|}{ MARYLAND } \\
\hline Total & 5,264 & 345,224 & $\$ 18,898,282$ & $\$ 11,746,788$ & $\$ 7,149,498$ & $\$ 945,402$ \\
\hline $\begin{array}{l}\text { Anne Arundel } \\
\text { Baltimore. } \\
\text { Calvert } \\
\text { Caroline. } \\
\text { Carroll }\end{array}$ & $\begin{array}{r}343 \\
63 \\
437 \\
317 \\
26\end{array}$ & $\begin{array}{r}20,992 \\
1,956 \\
34,352 \\
18,042 \\
1,847\end{array}$ & $\begin{array}{r}1,502,030 \\
292,789 \\
1,237,554 \\
817,700 \\
109,910\end{array}$ & $\begin{array}{r}966,474 \\
154,889 \\
726,449 \\
471,435 \\
70,585\end{array}$ & $\begin{array}{r}535,556 \\
137,900 \\
511,105 \\
346,265 \\
39,325\end{array}$ & $\begin{array}{r}62,631 \\
13,968 \\
58,512 \\
65,844 \\
5,625\end{array}$ \\
\hline $\begin{array}{l}\text { Cecil } \\
\text { Charles } \\
\text { Dorchester } \\
\text { Frederick. } \\
\text { Harford }\end{array}$ & $\begin{array}{r}34 \\
555 \\
327 \\
76 \\
98\end{array}$ & $\begin{array}{r}3,115 \\
50,137 \\
27,337 \\
4,235 \\
4,188\end{array}$ & $\begin{array}{r}184,765 \\
1,556,785 \\
1,331,175 \\
246,525 \\
429,000\end{array}$ & $\begin{array}{r}97,380 \\
916,245 \\
989,335 \\
110,695 \\
175,800\end{array}$ & $\begin{array}{r}87,385 \\
640,540 \\
341,840 \\
135,830 \\
253,200\end{array}$ & $\begin{array}{r}8,150 \\
85,074 \\
88,015 \\
19,362 \\
20,759\end{array}$ \\
\hline $\begin{array}{l}\text { Howard. } \\
\text { Kent } \\
\text { Montgomery } \\
\text { Prince Georges... }\end{array}$ & $\begin{array}{r}68 \\
141 \\
195 \\
581\end{array}$ & $\begin{array}{r}3,381 \\
7,330 \\
9,627 \\
46,478\end{array}$ & $\begin{array}{r}296,450 \\
399,220 \\
1,616,505 \\
2,873,359\end{array}$ & $\begin{array}{r}108,225 \\
250,745 \\
1,248,930 \\
1,799,889\end{array}$ & $\begin{array}{r}188,225 \\
148,475 \\
367,575 \\
1,073,470\end{array}$ & $\begin{array}{l}11,275 \\
18,519 \\
40,293 \\
99,411\end{array}$ \\
\hline
\end{tabular}


Table 38.-Farms Operated bx Negroes-Number, Acreage, and Value of Specified Classes of Farm Property, by States and Codnties, $1930-$ Continued

\begin{tabular}{|c|c|c|c|c|c|c|}
\hline \multirow{2}{*}{ STATE AND COUNTY } & \multirow{2}{*}{$\begin{array}{l}\text { Number } \\
\text { of farms }\end{array}$} & \multirow{2}{*}{$\begin{array}{l}\text { Land in } \\
\text { farms } \\
\text { (acres) }\end{array}$} & \multicolumn{3}{|c|}{ VALUE OF LAND AND BUILDINGS } & \multirow{2}{*}{$\begin{array}{l}\text { Value of } \\
\text { imple- } \\
\text { ments and } \\
\text { machinery }\end{array}$} \\
\hline & & & Total & Land alone & Buildings & \\
\hline & \multicolumn{6}{|c|}{ MARYLAND-continued } \\
\hline $\begin{array}{l}\text { Queen Annes. } \\
\text { St. Marys. } \\
\text { Somerset. } \\
\text { Talbot. }\end{array}$ & $\begin{array}{l}313 \\
305 \\
458 \\
196\end{array}$ & $\begin{array}{l}19,491 \\
22,245 \\
12,973 \\
13,096\end{array}$ & $\begin{array}{r}\$ 946,780 \\
993,899 \\
889,390 \\
1,146,045\end{array}$ & $\begin{array}{r}\$ 529,235 \\
575,914 \\
458,510 \\
752,995\end{array}$ & $\begin{array}{r}\$ 417,545 \\
417,985 \\
430,880 \\
393,050\end{array}$ & $\begin{array}{r}\$ 63,809 \\
46,192 \\
67,063 \\
64,450\end{array}$ \\
\hline $\begin{array}{l}\text { Washington } \\
\text { Wicomico } \\
\text { Worcester } \\
\text { Other counties. }\end{array}$ & $\begin{array}{r}20 \\
268 \\
441 \\
2\end{array}$ & $\begin{array}{r}1,277 \\
11,503 \\
30,822 \\
800\end{array}$ & $\begin{array}{r}85,600 \\
770,666 \\
1,161,935 \\
8,200\end{array}$ & $\begin{array}{r}43,525 \\
508,891 \\
784,040 \\
6,600\end{array}$ & $\begin{array}{r}42,075 \\
261,775 \\
377,895 \\
1,600\end{array}$ & $\begin{array}{r}2,495 \\
42,997 \\
60,708 \\
250\end{array}$ \\
\hline$=$ & \multicolumn{6}{|c|}{ MASSACHUSETTS } \\
\hline Total & 63 & 2,063 & $\$ 376,595$ & $\$ 201,400$ & $\$ 175,195$ & $\$ 19,320$ \\
\hline $\begin{array}{l}\text { Barnstable. } \\
\text { Bristol } \\
\text { Hampden } \\
\text { Middlesex } \\
\text { Plymouth } \\
\text { Other counties... }\end{array}$ & $\begin{array}{r}17 \\
15 \\
5 \\
5 \\
7 \\
14\end{array}$ & $\begin{array}{l}183 \\
366 \\
262 \\
167 \\
392 \\
693\end{array}$ & $\begin{array}{r}72,370 \\
53,700 \\
15,625 \\
43,800 \\
126,900 \\
64,200\end{array}$ & $\begin{array}{r}26,950 \\
25,700 \\
8,875 \\
15,800 \\
105,700 \\
18,375\end{array}$ & $\begin{array}{r}45,420 \\
28,000 \\
6,750 \\
28,000 \\
21,200 \\
45,825\end{array}$ & $\begin{array}{r}530 \\
2,440 \\
400 \\
1,050 \\
8,625 \\
6,275\end{array}$ \\
\hline Other counties............ & \multicolumn{6}{|c|}{ MICHIGAN } \\
\hline Total & 427 & 30,959 & $\$ 1,874,378$ & $\$ 1,045,563$ & $\$ 828,815$ & $\$ 137,755$ \\
\hline $\begin{array}{l}\text { Allegan } \\
\text { Berrien } \\
\text { Calhoun } \\
\text { Cass. } \\
\text { Eaton } \\
\text { Genesee. } \\
\text { Gratiot } \\
\text { Isabella } \\
\text { Kalamazoo } \\
\text { Kent.... }\end{array}$ & $\begin{array}{r}16 \\
27 \\
7 \\
105 \\
5 \\
\\
5 \\
8 \\
15 \\
9 \\
8\end{array}$ & $\begin{array}{r}941 \\
716 \\
392 \\
9,321 \\
231 \\
\\
181 \\
795 \\
1,654 \\
328 \\
507\end{array}$ & $\begin{array}{r}48,000 \\
106,800 \\
28,000 \\
471,800 \\
13,700 \\
15,900 \\
55,800 \\
47,500 \\
33,600 \\
40,300\end{array}$ & $\begin{array}{r}22,200 \\
50,375 \\
12,170 \\
265,700 \\
5,950 \\
7,600 \\
36,400 \\
27,800 \\
9,400 \\
20,100\end{array}$ & $\begin{array}{r}25,800 \\
56,425 \\
15,830 \\
206,100 \\
7,750 \\
8,300 \\
19,400 \\
19,700 \\
24,200 \\
20,200\end{array}$ & $\begin{array}{r}6,490 \\
7,075 \\
830 \\
35,330 \\
1,225 \\
1,200 \\
2,850 \\
4,427 \\
2,945 \\
1,500\end{array}$ \\
\hline $\begin{array}{l}\text { Lake } \\
\text { Manistee. } \\
\text { Mecosta. } \\
\text { Midland. } \\
\text { Monroe. }\end{array}$ & $\begin{array}{r}13 \\
5 \\
32 \\
11 \\
8\end{array}$ & $\begin{array}{r}925 \\
274 \\
2,628 \\
833 \\
510\end{array}$ & $\begin{array}{r}24,348 \\
8,100 \\
104,500 \\
21,850 \\
49,800\end{array}$ & $\begin{array}{r}16,148 \\
4,500 \\
65,670 \\
13,150 \\
27,900\end{array}$ & $\begin{array}{r}8,200 \\
3,600 \\
38,830 \\
8,700 \\
20,900\end{array}$ & $\begin{array}{r}2,930 \\
450 \\
7,355 \\
1,450 \\
3,050\end{array}$ \\
\hline $\begin{array}{l}\text { Montcalm } \\
\text { St. Clair } \\
\text { Van Buren } \\
\text { Washtenaw } \\
\text { Wayne } \\
\text { Other counties. }\end{array}$ & $\begin{array}{r}8 \\
5 \\
55 \\
22 \\
5 \\
58\end{array}$ & $\begin{array}{r}666 \\
430 \\
3,270 \\
1,405 \\
269 \\
4,683\end{array}$ & $\begin{array}{r}28,300 \\
27,850 \\
295,530 \\
203,000 \\
45,000 \\
205,700\end{array}$ & $\begin{array}{r}14,900 \\
16,250 \\
164,530 \\
120,300 \\
28,800 \\
115,720\end{array}$ & $\begin{array}{r}13,400 \\
11,600 \\
131,000 \\
82,700 \\
16,200 \\
89,980\end{array}$ & $\begin{array}{r}2,050 \\
960 \\
22,483 \\
8,320 \\
3,350 \\
21,485\end{array}$ \\
\hline Other counties....... & \multicolumn{6}{|c|}{ MINNESOTA } \\
\hline Total ............. & 27 & 2,692 & $\$ 187,325$ & $\$ 107,625$ & $\$ 79,700$ & $\$ 18,965$ \\
\hline \multirow[t]{2}{*}{$\begin{array}{l}\text { Hennepin } \\
\text { Other counties..... }\end{array}$} & $\begin{array}{r}5 \\
22\end{array}$ & $\begin{array}{r}65 \\
2,627\end{array}$ & $\begin{array}{r}45,100 \\
142,225\end{array}$ & $\begin{array}{l}26,600 \\
81,025\end{array}$ & $\begin{array}{l}18,500 \\
61,200\end{array}$ & $\begin{array}{r}8,590 \\
10,375\end{array}$ \\
\hline & \multicolumn{6}{|c|}{ MISSISSIPPI } \\
\hline Total & 182,578 & $6,062,490$ & $\$ 249,305,432$ & $\$ 191,685,807$ & $857,619,625$ & $811,100,211$ \\
\hline $\begin{array}{l}\text { Adams } \\
\text { Alcorn } \\
\text { Amite } \\
\text { Attala } \\
\text { Benton }\end{array}$ & $\begin{array}{r}1,476 \\
427 \\
1,888 \\
1,952 \\
1,053\end{array}$ & $\begin{array}{l}41,702 \\
16,306 \\
92,491 \\
93,640 \\
65,252\end{array}$ & $\begin{array}{r}1,509,799 \\
518,565 \\
1,471,677 \\
1,672,852 \\
900,965\end{array}$ & $\begin{array}{r}982,440 \\
376,680 \\
930,677 \\
1,196,902 \\
634,550\end{array}$ & $\begin{array}{l}527,359 \\
141,885 \\
541,000 \\
475,950 \\
266,415\end{array}$ & $\begin{array}{r}70,281 \\
26,064 \\
120,375 \\
124,915 \\
75,563\end{array}$ \\
\hline
\end{tabular}


Table 38.-Farms Operated by Negroes-Number, Acreage, and Valde of Specified Classes of Farm Property, by States and Counties, $1930-$ Continued

\begin{tabular}{|c|c|c|c|c|c|c|}
\hline \multirow{2}{*}{ STATE AND COUNTY } & \multirow{2}{*}{$\begin{array}{l}\text { Number } \\
\text { of farms }\end{array}$} & \multirow{2}{*}{$\begin{array}{l}\text { Land in } \\
\text { farms } \\
\text { (acres) }\end{array}$} & \multicolumn{3}{|c|}{ VALUE OF LAND AND BUILDINGS } & \multirow{2}{*}{$\begin{array}{l}\text { Value of } \\
\text { imple- } \\
\text { ments and } \\
\text { machinery }\end{array}$} \\
\hline & & & Total & Land alone & Buildings & \\
\hline & \multicolumn{6}{|c|}{ MISSISSIPPI-continued } \\
\hline $\begin{array}{l}\text { Bolivar } \\
\text { Calhoun } \\
\text { Carroll } \\
\text { Chickasaw } \\
\text { Choctaw }\end{array}$ & $\begin{array}{r}13,236 \\
651 \\
2,652 \\
1,751 \\
567\end{array}$ & $\begin{array}{r}262,850 \\
24,253 \\
109,287 \\
82,282 \\
35,344\end{array}$ & $\begin{array}{r}\$ 25,134,819 \\
598,764 \\
1,998,118 \\
1,754,970 \\
359,707\end{array}$ & $\begin{array}{r}\$ 20,479,564 \\
424,512 \\
1,468,900 \\
1,265,742 \\
239,539\end{array}$ & $\begin{array}{r}\$ 4,655,255 \\
174,252 \\
529,218 \\
489,228 \\
120,168\end{array}$ & $\begin{array}{r}\$ 500,237 \\
71,117 \\
170,740 \\
159,447 \\
30,857\end{array}$ \\
\hline $\begin{array}{l}\text { Claiborne } \\
\text { Clarke } \\
\text { Clay } \\
\text { Coahoma }\end{array}$ & $\begin{array}{l}1,643 \\
898 \\
2,006 \\
8,440 \\
2,521\end{array}$ & $\begin{array}{r}78,563 \\
42,395 \\
72,179 \\
170,885 \\
88,654\end{array}$ & $\begin{array}{r}1,478,178 \\
649,979 \\
1,846,210 \\
18,029,568 \\
1,914,999\end{array}$ & $\begin{array}{r}948,648 \\
425,014 \\
1,340,043 \\
14,716,657 \\
1,204,005\end{array}$ & $\begin{array}{r}529,530 \\
224,965 \\
506,167 \\
3,312,911 \\
710,994\end{array}$ & $\begin{array}{r}171,142 \\
39,302 \\
110,886 \\
209,844 \\
127,919\end{array}$ \\
\hline $\begin{array}{l}\text { Covington... } \\
\text { De Soto...... } \\
\text { Forrest....... } \\
\text { Franklin..... } \\
\text { George....... }\end{array}$ & $\begin{array}{r}781 \\
4,312 \\
224 \\
646 \\
89\end{array}$ & $\begin{array}{r}37,967 \\
155,850 \\
10,420 \\
27,598 \\
4,546\end{array}$ & $\begin{array}{r}873,167 \\
6,080,320 \\
308,641 \\
466,578 \\
86,275\end{array}$ & $\begin{array}{r}634,642 \\
4,655,908 \\
209,370 \\
292,273 \\
55,585\end{array}$ & $\begin{array}{r}238,525 \\
1,424,412 \\
99,271 \\
174,305 \\
30,690\end{array}$ & $\begin{array}{r}43,880 \\
357,900 \\
11,780 \\
28,990 \\
5,372\end{array}$ \\
\hline 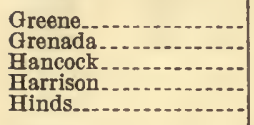 & $\begin{array}{r}134 \\
1,585 \\
49 \\
52 \\
5,362\end{array}$ & $\begin{array}{r}6,781 \\
80,694 \\
3,602 \\
1,630 \\
181,797\end{array}$ & $\begin{array}{r}112,618 \\
1,309,845 \\
102,125 \\
94,225 \\
6,783,114\end{array}$ & $\begin{array}{r}58,248 \\
917,424 \\
73,000 \\
68,080 \\
4,914,146\end{array}$ & $\begin{array}{r}54,370 \\
392,421 \\
29,125 \\
26,145 \\
1,868,968\end{array}$ & $\begin{array}{r}4,721 \\
86,273 \\
4,330 \\
6,822 \\
318,137\end{array}$ \\
\hline $\begin{array}{l}\text { Holmes. } \\
\text { Humphreys... } \\
\text { Issaquena } \\
\text { Itawamba...... } \\
\text { Jackson }\end{array}$ & $\begin{array}{r}5,660 \\
4,364 \\
1,215 \\
158 \\
38\end{array}$ & $\begin{array}{r}197,793 \\
91,813 \\
27,259 \\
8,908 \\
2,210\end{array}$ & $\begin{array}{r}6,717,183 \\
7,993,998 \\
1,585,829 \\
161,770 \\
54,200\end{array}$ & $\begin{array}{r}4,973,813 \\
6,525,609 \\
1,086,784 \\
128,865 \\
31,090\end{array}$ & $\begin{array}{r}1,743,370 \\
1,468,389 \\
499,045 \\
32,905 \\
23,110\end{array}$ & $\begin{array}{r}384,632 \\
334,936 \\
104,273 \\
10,036 \\
3,752\end{array}$ \\
\hline 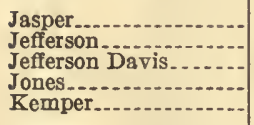 & $\begin{array}{l}1,418 \\
2,068 \\
1,706 \\
577 \\
2,281\end{array}$ & $\begin{array}{r}79,825 \\
86,359 \\
81,925 \\
26,468 \\
115,666\end{array}$ & $\begin{array}{r}1,065,723 \\
1,581,853 \\
1,997,567 \\
689,820 \\
1,786,594\end{array}$ & $\begin{array}{r}749,400 \\
1,037,450 \\
1,473,612 \\
462,725 \\
1,216,964\end{array}$ & $\begin{array}{l}316,323 \\
544,403 \\
523,955 \\
227,095 \\
569,630\end{array}$ & $\begin{array}{r}56,026 \\
176,843 \\
94,213 \\
37,153 \\
102,817\end{array}$ \\
\hline $\begin{array}{l}\text { Lafayette...... } \\
\text { Lamar. } \\
\text { Lauderdale...... } \\
\text { Lawrence...... } \\
\text { Leake.......... }\end{array}$ & $\begin{array}{r}1,510 \\
95 \\
1,492 \\
911 \\
1,422\end{array}$ & $\begin{array}{r}88,576 \\
4,019 \\
81,179 \\
42,774 \\
65,232\end{array}$ & $\begin{array}{r}1,301,023 \\
99,655 \\
1,694,398 \\
791,008 \\
1,335,622\end{array}$ & $\begin{array}{r}924,018 \\
66,085 \\
1,160,786 \\
557,122 \\
962,797\end{array}$ & $\begin{array}{r}377,005 \\
33,570 \\
533,612 \\
233,886 \\
372,825\end{array}$ & $\begin{array}{r}120,462 \\
5,660 \\
78,507 \\
51,881 \\
105,314\end{array}$ \\
\hline $\begin{array}{l}\text { Lee } \\
\text { Leflore } \\
\text { Lincoln } \\
\text { Lowndes....... } \\
\text { Madison......... }\end{array}$ & $\begin{array}{l}2,011 \\
8,778 \\
1,093 \\
2,510 \\
5,572\end{array}$ & $\begin{array}{r}54,864 \\
197,740 \\
50,178 \\
90,764 \\
196,853\end{array}$ & $\begin{array}{r}2,821,340 \\
18,398,663 \\
741,180 \\
2,683,049 \\
6,782,988\end{array}$ & $\begin{array}{r}2,253,026 \\
14,990,257 \\
483,327 \\
1,955,859 \\
4,914,995\end{array}$ & $\begin{array}{r}568,314 \\
3,408,406 \\
257,853 \\
727,190 \\
1,867,993\end{array}$ & $\begin{array}{r}159,535 \\
656,127 \\
31,551 \\
208,744 \\
474,335\end{array}$ \\
\hline $\begin{array}{l}\text { Marion } \\
\text { Marshall... } \\
\text { Monroe } \\
\text { Montgomery } \\
\text { Neshoba.... }\end{array}$ & $\begin{array}{r}985 \\
3,704 \\
2,842 \\
1,073 \\
952\end{array}$ & $\begin{array}{r}38,197 \\
233,802 \\
109,563 \\
53,073 \\
32,979\end{array}$ & $\begin{array}{r}864,285 \\
3,714,479 \\
3,804,340 \\
1,190,338 \\
847,574\end{array}$ & $\begin{array}{r}631,021 \\
2,654,016 \\
2,970,974 \\
884,972 \\
617,894\end{array}$ & $\begin{array}{r}233,264 \\
1,060,463 \\
833,366 \\
305,366 \\
229,680\end{array}$ & $\begin{array}{r}35,623 \\
236,367 \\
242,089 \\
97,576 \\
74,169\end{array}$ \\
\hline $\begin{array}{l}\text { Newton } \\
\text { Noxubee } \\
\text { Oktibbeha. } \\
\text { Panola } \\
\text { Pearl River. }\end{array}$ & $\begin{array}{r}1,323 \\
3,973 \\
1,879 \\
4,007 \\
120\end{array}$ & $\begin{array}{r}63,487 \\
122,611 \\
87,479 \\
144,301 \\
4,731\end{array}$ & $\begin{array}{r}1,427,310 \\
3,386,762 \\
1,797,460 \\
3,597,786 \\
159,475\end{array}$ & $\begin{array}{r}1,066,896 \\
2,375,432 \\
1,161,855 \\
2,579,658 \\
90,405\end{array}$ & $\begin{array}{r}360,414 \\
1,011,330 \\
635,605 \\
1,018,128 \\
69,070\end{array}$ & $\begin{array}{r}105,230 \\
268,141 \\
147,825 \\
280,551 \\
7,555\end{array}$ \\
\hline $\begin{array}{l}\text { Perry } \\
\text { Pike } \\
\text { Pontotoc. } \\
\text { Prentiss } \\
\text { Quitman. }\end{array}$ & $\begin{array}{r}270 \\
1,803 \\
818 \\
421 \\
4,382\end{array}$ & $\begin{array}{l}17,330 \\
85,322 \\
33,388 \\
14,023 \\
98,616\end{array}$ & $\begin{array}{r}311,627 \\
1,763,714 \\
879,642 \\
565,163 \\
7,502,706\end{array}$ & $\begin{array}{r}208,423 \\
1,190,418 \\
667,662 \\
458,238 \\
6,141,118\end{array}$ & $\begin{array}{r}103,204 \\
573,296 \\
211,980 \\
106,925 \\
1,361,588\end{array}$ & $\begin{array}{r}16,631 \\
93,254 \\
55,982 \\
32,656 \\
162,039\end{array}$ \\
\hline 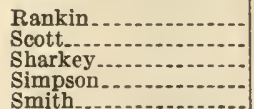 & $\begin{array}{r}1,893 \\
1,158 \\
2,657 \\
1,123 \\
475\end{array}$ & $\begin{array}{l}82,359 \\
49,093 \\
52,557 \\
49,947 \\
20,441\end{array}$ & $\begin{array}{r}1,571,282 \\
941,650 \\
4,692,869 \\
1,079,857 \\
444,865\end{array}$ & $\begin{array}{r}1,166,854 \\
640,587 \\
3,717,754 \\
752,538 \\
322,020\end{array}$ & $\begin{array}{l}404,428 \\
301,063 \\
975,115 \\
327,319 \\
122,845\end{array}$ & $\begin{array}{r}95,355 \\
55,933 \\
138,827 \\
61,821 \\
21,230\end{array}$ \\
\hline
\end{tabular}


Table 38. -Farms Operated by Negroes-Number, Acreage, and Value of Specified Classes of Farm Property, by States and Counties, 1930Continued

\begin{tabular}{|c|c|c|c|c|c|c|}
\hline \multirow{2}{*}{ STATE AND COUNTY } & \multirow{2}{*}{$\begin{array}{l}\text { Number } \\
\text { of farms }\end{array}$} & \multirow{2}{*}{$\begin{array}{l}\text { Land in } \\
\text { farms } \\
\text { (acres) }\end{array}$} & \multicolumn{3}{|c|}{ VALUE OF LAND AND BUILDINGS } & \multirow{2}{*}{$\begin{array}{l}\text { Value of } \\
\text { imple- } \\
\text { ments and } \\
\text { machinery }\end{array}$} \\
\hline & & & Total & Land alone & Buildings & \\
\hline & \multicolumn{6}{|c|}{ MISSISSIPPI-continued } \\
\hline $\begin{array}{l}\text { Stone } \\
\text { Sunflower } \\
\text { Tallahatchie } \\
\text { Tate } \\
\text { Tippah. }\end{array}$ & $\begin{array}{r}127 \\
11,644 \\
5,523 \\
2,687 \\
526\end{array}$ & $\begin{array}{r}5,421 \\
243,010 \\
129,626 \\
98,427 \\
24,150\end{array}$ & $\begin{array}{r}\$ 122,375 \\
24,226,094 \\
9,888,853 \\
2,293,151 \\
498,110\end{array}$ & $\begin{array}{r}\$ 83,622 \\
20,251,897 \\
7,900,567 \\
1,600,246 \\
357,105\end{array}$ & $\begin{array}{r}\$ 38,753 \\
3,974,197 \\
1,988,286 \\
682,905 \\
141,005\end{array}$ & $\begin{array}{r}\$ 6,399 \\
925,693 \\
170,624 \\
158,521 \\
32,317\end{array}$ \\
\hline $\begin{array}{l}\text { Tishomingo } \\
\text { Tunica } \\
\text { Unlon } \\
\text { Walthall }\end{array}$ & $\begin{array}{r}128 \\
4,942 \\
677 \\
1,188\end{array}$ & $\begin{array}{r}6,954 \\
106,259 \\
26,405 \\
48,959\end{array}$ & $\begin{array}{r}122,175 \\
9,213,651 \\
949,015 \\
1,157,160\end{array}$ & $\begin{array}{r}93,885 \\
7,267,067 \\
714,512 \\
860,242\end{array}$ & $\begin{array}{r}28,290 \\
1,946,584 \\
234,503 \\
296,918\end{array}$ & $\begin{array}{r}6,880 \\
116,605 \\
53,030 \\
70,415\end{array}$ \\
\hline $\begin{array}{l}\text { Warren } \\
\text { Washington. } \\
\text { Wayne... } \\
\text { Webster........... }\end{array}$ & $\begin{array}{r}1,642 \\
7,652 \\
593 \\
412\end{array}$ & $\begin{array}{r}52,881 \\
148,225 \\
30,236 \\
21,728\end{array}$ & $\begin{array}{r}1,544,430 \\
12,929,156 \\
551,728 \\
322,810\end{array}$ & $\begin{array}{r}1,085,787 \\
10,133,603 \\
367,893 \\
230,355\end{array}$ & $\begin{array}{r}458,643 \\
2,795,553 \\
183,835 \\
92,455\end{array}$ & $\begin{array}{r}121,322 \\
498,799 \\
32,556 \\
26,289\end{array}$ \\
\hline \multirow[t]{3}{*}{$\begin{array}{l}\text { Wilkinson } \\
\text { Winston } \\
\text { Yalobusha } \\
\text { Yazoo }\end{array}$} & $\begin{array}{l}1,578 \\
1,319 \\
1,420 \\
5,388\end{array}$ & $\begin{array}{r}55,328 \\
66,263 \\
77,762 \\
150,184\end{array}$ & $\begin{array}{r}883,448 \\
1,009,151 \\
1,169,570 \\
5,541,830\end{array}$ & $\begin{array}{r}551,544 \\
641,703 \\
838,315 \\
3,941,596\end{array}$ & $\begin{array}{r}331,904 \\
367,448 \\
331,255 \\
1,600,234\end{array}$ & $\begin{array}{r}75,798 \\
86,429 \\
92,054 \\
323,929\end{array}$ \\
\hline & \multicolumn{6}{|c|}{ MISSOURI } \\
\hline & 5,844 & 255,623 & $814,498,297$ & $811,768,662$ & $82,728,435$ & 8498,459 \\
\hline $\begin{array}{l}\text { Audrain } \\
\text { Benton....... } \\
\text { Boone } \\
\text { Butler........ } \\
\text { Callawsy... }\end{array}$ & $\begin{array}{r}25 \\
14 \\
71 \\
97 \\
182\end{array}$ & $\begin{array}{r}2,101 \\
836 \\
5,717 \\
5,094 \\
13,510\end{array}$ & $\begin{array}{r}81,340 \\
29,900 \\
288,700 \\
140,500 \\
326,981\end{array}$ & $\begin{array}{r}51,090 \\
24,000 \\
214,815 \\
105,010 \\
215,981\end{array}$ & $\begin{array}{r}30,250 \\
5,900 \\
73,885 \\
35,490 \\
111,000\end{array}$ & $\begin{array}{r}4,345 \\
1,530 \\
7,475 \\
7,626 \\
15,598\end{array}$ \\
\hline $\begin{array}{l}\text { Cape Girardeau } \\
\text { Carroll } \\
\text { Cass } \\
\text { Chariton } \\
\text { Clay }\end{array}$ & $\begin{array}{r}40 \\
18 \\
5 \\
74 \\
6\end{array}$ & $\begin{array}{r}2,945 \\
2,304 \\
73 \\
5,986 \\
174\end{array}$ & $\begin{array}{r}100,810 \\
153,850 \\
12,200 \\
282,605 \\
25,100\end{array}$ & $\begin{array}{r}69,890 \\
141,900 \\
7,950 \\
215,280 \\
13,700\end{array}$ & $\begin{array}{r}30,920 \\
11,950 \\
4,250 \\
67,325 \\
11,400\end{array}$ & $\begin{array}{r}4,245 \\
6,205 \\
257 \\
21,645 \\
60\end{array}$ \\
\hline $\begin{array}{l}\text { Clinton } \\
\text { Cole } \\
\text { Cooper } \\
\text { Dade } \\
\text { De Kaib. } \\
\end{array}$ & $\begin{array}{r}18 \\
11 \\
105 \\
9 \\
5\end{array}$ & $\begin{array}{r}886 \\
1,035 \\
7,302 \\
362 \\
295\end{array}$ & $\begin{array}{r}49,980 \\
75,940 \\
379,900 \\
14,850 \\
15,325\end{array}$ & $\begin{array}{r}38,780 \\
64,070 \\
291,940 \\
10,200 \\
10,025\end{array}$ & $\begin{array}{r}11,200 \\
11,870 \\
87,960 \\
4,650 \\
5,300\end{array}$ & $\begin{array}{r}1,870 \\
1,032 \\
11,529 \\
690 \\
740\end{array}$ \\
\hline $\begin{array}{l}\text { Dunklin } \\
\text { Franklin } \\
\text { Gasconade } \\
\text { Greene. } \\
\text { Henry }\end{array}$ & $\begin{array}{r}46 \\
42 \\
6 \\
46 \\
15\end{array}$ & $\begin{array}{l}1,336 \\
3,180 \\
1,002 \\
1,905 \\
1,520\end{array}$ & $\begin{array}{r}69,880 \\
129,930 \\
20,500 \\
219,100 \\
59,230\end{array}$ & $\begin{array}{r}53,745 \\
99,035 \\
10,893 \\
154,275 \\
49,905\end{array}$ & $\begin{array}{r}16,135 \\
30,895 \\
9,607 \\
64,825 \\
9,325\end{array}$ & $\begin{array}{l}2,500 \\
3,795 \\
1,830 \\
6,312 \\
2,185\end{array}$ \\
\hline $\begin{array}{l}\text { Howard } \\
\text { Howell } \\
\text { Iron } \\
\text { Jackson } \\
\text { Jefferson }\end{array}$ & $\begin{array}{r}71 \\
5 \\
5 \\
15 \\
7\end{array}$ & $\begin{array}{r}7,199 \\
440 \\
233 \\
761 \\
660\end{array}$ & $\begin{array}{r}317,130 \\
8,700 \\
10,450 \\
184,800 \\
32,000\end{array}$ & $\begin{array}{r}228,210 \\
6,350 \\
5,550 \\
152,760 \\
22,950\end{array}$ & $\begin{array}{r}88,920 \\
2,350 \\
4,900 \\
32,040 \\
9,050\end{array}$ & $\begin{array}{r}9,475 \\
315 \\
855 \\
8,945 \\
990\end{array}$ \\
\hline $\begin{array}{l}\text { Johnson } \\
\text { Laclede. } \\
\text { Lafayette. } \\
\text { Lawrence. } \\
\text { Lewis...... }\end{array}$ & $\begin{array}{r}46 \\
7 \\
38 \\
7 \\
14\end{array}$ & $\begin{array}{r}3,237 \\
927 \\
2,580 \\
749 \\
2,585\end{array}$ & $\begin{array}{r}140,860 \\
19,400 \\
196,865 \\
32,190 \\
119,440\end{array}$ & $\begin{array}{r}114,945 \\
13,900 \\
166,005 \\
26,190 \\
90,899\end{array}$ & $\begin{array}{r}25,915 \\
5,500 \\
30,860 \\
6,000 \\
28,541\end{array}$ & $\begin{array}{r}4,735 \\
580 \\
4,170 \\
1,850 \\
6,172\end{array}$ \\
\hline $\begin{array}{l}\text { Lincoln } \\
\text { Linn } \\
\text { Livingston } \\
\text { Macon } \\
\text { Marion. }\end{array}$ & $\begin{array}{r}57 \\
5 \\
8 \\
15 \\
30\end{array}$ & $\begin{array}{r}4,179 \\
356 \\
449 \\
855 \\
2,449\end{array}$ & $\begin{array}{r}155,495 \\
20,860 \\
30,970 \\
32,255 \\
117,534\end{array}$ & $\begin{array}{r}119,800 \\
17,060 \\
17,670 \\
22,362 \\
94,184\end{array}$ & $\begin{array}{r}35,695 \\
3,800 \\
13,300 \\
9,893 \\
23,350\end{array}$ & $\begin{array}{r}6,502 \\
550 \\
465 \\
870 \\
3,780\end{array}$ \\
\hline $\begin{array}{l}\text { Miller } \\
\text { Mississippi. } \\
\text { Moniteau } \\
\text { Monroe.... } \\
\text { Montgomery } \\
\end{array}$ & $\begin{array}{r}10 \\
651 \\
6 \\
27 \\
33\end{array}$ & $\begin{array}{r}670 \\
19,286 \\
1,175 \\
2,614 \\
3,282\end{array}$ & $\begin{array}{r}14,640 \\
1,499,865 \\
35,000 \\
98,850 \\
93,900\end{array}$ & $\begin{array}{r}10,840 \\
1,296,525 \\
26,750 \\
64,100 \\
65,610\end{array}$ & $\begin{array}{r}3,800 \\
203,340 \\
8,250 \\
34,750 \\
28,290\end{array}$ & $\begin{array}{r}277 \\
50,877 \\
3,000 \\
3,630 \\
4,945\end{array}$ \\
\hline
\end{tabular}


Table 38. -Farms Operated by Negroes-Number, Acreage, and Value of Specified Classes of Farm Property, by States and Counties, 1930Continued

\begin{tabular}{|c|c|c|c|c|c|c|}
\hline \multirow{2}{*}{ STATE AND COUNTY } & \multirow{2}{*}{$\begin{array}{l}\text { Number } \\
\text { of farms }\end{array}$} & \multirow{2}{*}{$\begin{array}{l}\text { Land in } \\
\text { farms } \\
\text { (acres) }\end{array}$} & \multicolumn{3}{|c|}{ VALUE OF LAND AND BUTLDINGS } & \multirow{2}{*}{$\begin{array}{l}\text { Value of } \\
\text { imple- } \\
\text { ments and } \\
\text { machinery }\end{array}$} \\
\hline & & & Total & Land alone & Buildings & \\
\hline - & \multicolumn{6}{|c|}{ MrssoURJ-continued } \\
\hline $\begin{array}{l}\text { Morgan } \\
\text { New Madridis } \\
\text { Newton } \\
\text { Pemiscot.2 } \\
\text { Perry }\end{array}$ & $\begin{array}{r}13 \\
998 \\
17 \\
1,891 \\
7\end{array}$ & $\begin{array}{r}1,057 \\
30,283 \\
1,034 \\
43,026 \\
356\end{array}$ & $\begin{array}{r}\$ 38,740 \\
1,727,722 \\
47,820 \\
3,357,153 \\
10,945\end{array}$ & $\begin{array}{r}\$ 29,330 \\
1,483,022 \\
39,370 \\
2,828,611 \\
7,145\end{array}$ & $\begin{array}{r}\$ 9,410 \\
244,700 \\
8,450 \\
528,542 \\
3,800\end{array}$ & $\begin{array}{r}\$ 1,765 \\
60,165 \\
1,890 \\
97,490 \\
300\end{array}$ \\
\hline $\begin{array}{l}\text { Pettis } \\
\text { Pike } \\
\text { Platte-. } \\
\text { Ralls } \\
\text { Randolph } \\
\end{array}$ & $\begin{array}{r}61 \\
151 \\
6 \\
29 \\
54\end{array}$ & $\begin{array}{r}3,128 \\
11,217 \\
725 \\
2,644 \\
3,297\end{array}$ & $\begin{array}{r}218,365 \\
387,169 \\
48,150 \\
116,390 \\
145,930\end{array}$ & $\begin{array}{r}157,215 \\
271,637 \\
40,850 \\
93,265 \\
102,105\end{array}$ & $\begin{array}{r}61,150 \\
115,532 \\
7,300 \\
23,125 \\
43,825\end{array}$ & $\begin{array}{r}6,430 \\
15,097 \\
4,310 \\
4,035 \\
3,840\end{array}$ \\
\hline $\begin{array}{l}\text { Ray } \\
\text { St. Charles.... } \\
\text { St. Clair } \\
\text { St. Louis... } \\
\text { Ste. Genevieve...... }\end{array}$ & $\begin{array}{r}11 \\
44 \\
6 \\
21 \\
9\end{array}$ & $\begin{array}{r}1,068 \\
2,244 \\
328 \\
766 \\
785\end{array}$ & $\begin{array}{r}60,200 \\
117,040 \\
7,300 \\
337,900 \\
26,400\end{array}$ & $\begin{array}{r}51,140 \\
87,055 \\
4,850 \\
297,050 \\
15,025\end{array}$ & $\begin{array}{r}9,060 \\
29,985 \\
2,450 \\
40,850 \\
11,375\end{array}$ & $\begin{array}{l}1,320 \\
3,598 \\
355 \\
3,626 \\
1,755\end{array}$ \\
\hline $\begin{array}{l}\text { Saline } \\
\text { Scott } \\
\text { Shelby } \\
\text { Stoddard }\end{array}$ & $\begin{array}{r}96 \\
150 \\
21 \\
268\end{array}$ & $\begin{array}{r}8,836 \\
6,738 \\
1,665 \\
14,819\end{array}$ & $\begin{array}{r}675,990 \\
348,990 \\
55,635 \\
860,133\end{array}$ & $\begin{array}{r}581,550 \\
286,245 \\
40,635 \\
739,688\end{array}$ & $\begin{array}{r}94,440 \\
62,745 \\
15.000 \\
120,445\end{array}$ & $\begin{array}{r}26,414 \\
10,747 \\
1,900 \\
21,216\end{array}$ \\
\hline $\begin{array}{l}\text { Warren } \\
\text { Washington } \\
\text { Wright } \\
\text { Other counties.............. }\end{array}$ & $\begin{array}{r}15 \\
7 \\
37 \\
40\end{array}$ & $\begin{array}{l}1,428 \\
425 \\
3,874 \\
3,633\end{array}$ & $\begin{array}{r}26,940 \\
7,850 \\
77,350 \\
160,360\end{array}$ & $\begin{array}{r}15,565 \\
4,925 \\
61,225 \\
127,215\end{array}$ & $\begin{array}{r}11,375 \\
2,925 \\
16,125 \\
33,145\end{array}$ & $\begin{array}{r}1,525 \\
300 \\
4,745 \\
6,184\end{array}$ \\
\hline - & \multicolumn{6}{|c|}{ MONTANA } \\
\hline \multirow[t]{2}{*}{ Total } & 21 & 9,804 & 8115,084 & $\$ 88,689$ & $\$ 18,885$ & $\$ 15,590$ \\
\hline & \multicolumn{6}{|c|}{ NEBRASKA } \\
\hline Total_.. & 38 & 9,216 & $\$ 308,080$ & $\$ 241,190$ & $\$ 88,890$ & $\$ 28,434$ \\
\hline \multirow[t]{2}{*}{$\begin{array}{l}\text { Box Butte.... } \\
\text { Cherry } \\
\text { Otber counties......... }\end{array}$} & $\begin{array}{r}7 \\
5 \\
26\end{array}$ & $\begin{array}{l}3,241 \\
2,022 \\
3,953\end{array}$ & $\begin{array}{r}139,500 \\
17,670 \\
150,910\end{array}$ & $\begin{array}{r}110,150 \\
13,420 \\
117,620\end{array}$ & $\begin{array}{r}29,350 \\
4,250 \\
33,290\end{array}$ & $\begin{array}{r}17,575 \\
2,200 \\
8,659\end{array}$ \\
\hline & \multicolumn{6}{|c|}{ NEVADA } \\
\hline \multirow{4}{*}{ Total $\ldots . . . . . . . .}$. & s & 860 & $\$ 44,000$ & $\$ \$ 6,500$ & $\$ 7,500$ & $\$ 1,250$ \\
\hline & \multicolumn{6}{|c|}{ NEW HAMPSHIRE } \\
\hline & 6 & 814 & $\$ 18,000$ & $\$ 5,950$ & 812,050 & $\$ 2,050$ \\
\hline & \multicolumn{6}{|c|}{ NEW JERSEY } \\
\hline Total... & 372 & 19,288 & $82,070,400$ & $\$ 1,142,690$ & $\$ 927,710$ & $\$ 179,223$ \\
\hline $\begin{array}{l}\text { Atlantic } \\
\text { Burlington. } \\
\text { Camden } \\
\text { Cape May. } \\
\text { Cumberland...... }\end{array}$ & $\begin{array}{r}42 \\
26 \\
10 \\
6 \\
102\end{array}$ & $\begin{array}{r}497 \\
1,021 \\
252 \\
437 \\
7,167\end{array}$ & $\begin{array}{r}168,800 \\
153,900 \\
101,800 \\
39,200 \\
442,400\end{array}$ & $\begin{array}{r}85,750 \\
81,800 \\
67,400 \\
25,800 \\
232,900\end{array}$ & $\begin{array}{r}83,050 \\
72,100 \\
34,400 \\
13,400 \\
209,500\end{array}$ & $\begin{array}{r}8,640 \\
15,300 \\
3,675 \\
1,450 \\
46,555\end{array}$ \\
\hline $\begin{array}{l}\text { Gloucester } \\
\text { Mercer } \\
\text { Monmouth } \\
\text { Salem } \\
\text { Somerset... } \\
\text { Other counties. }\end{array}$ & $\begin{array}{r}52 \\
11 \\
24 \\
74 \\
6 \\
19\end{array}$ & $\begin{array}{r}2,521 \\
926 \\
509 \\
4,794 \\
410 \\
764\end{array}$ & $\begin{array}{l}279,500 \\
137,200 \\
114,400 \\
268,100 \\
193,000 \\
172,100\end{array}$ & $\begin{array}{r}160,750 \\
99,700 \\
62,390 \\
129,300 \\
113,500 \\
83,400\end{array}$ & $\begin{array}{r}118,750 \\
37,500 \\
52,010 \\
138,800 \\
79,500 \\
88,700\end{array}$ & $\begin{array}{r}32,835 \\
6,200 \\
12,700 \\
31,995 \\
5,500 \\
8,373\end{array}$ \\
\hline
\end{tabular}


Table 38. -Farms Operated by Negroes-Number, Acreage, and Value: of Specified Classes of Farm Property, by States and Counties, $1930-$ Continued

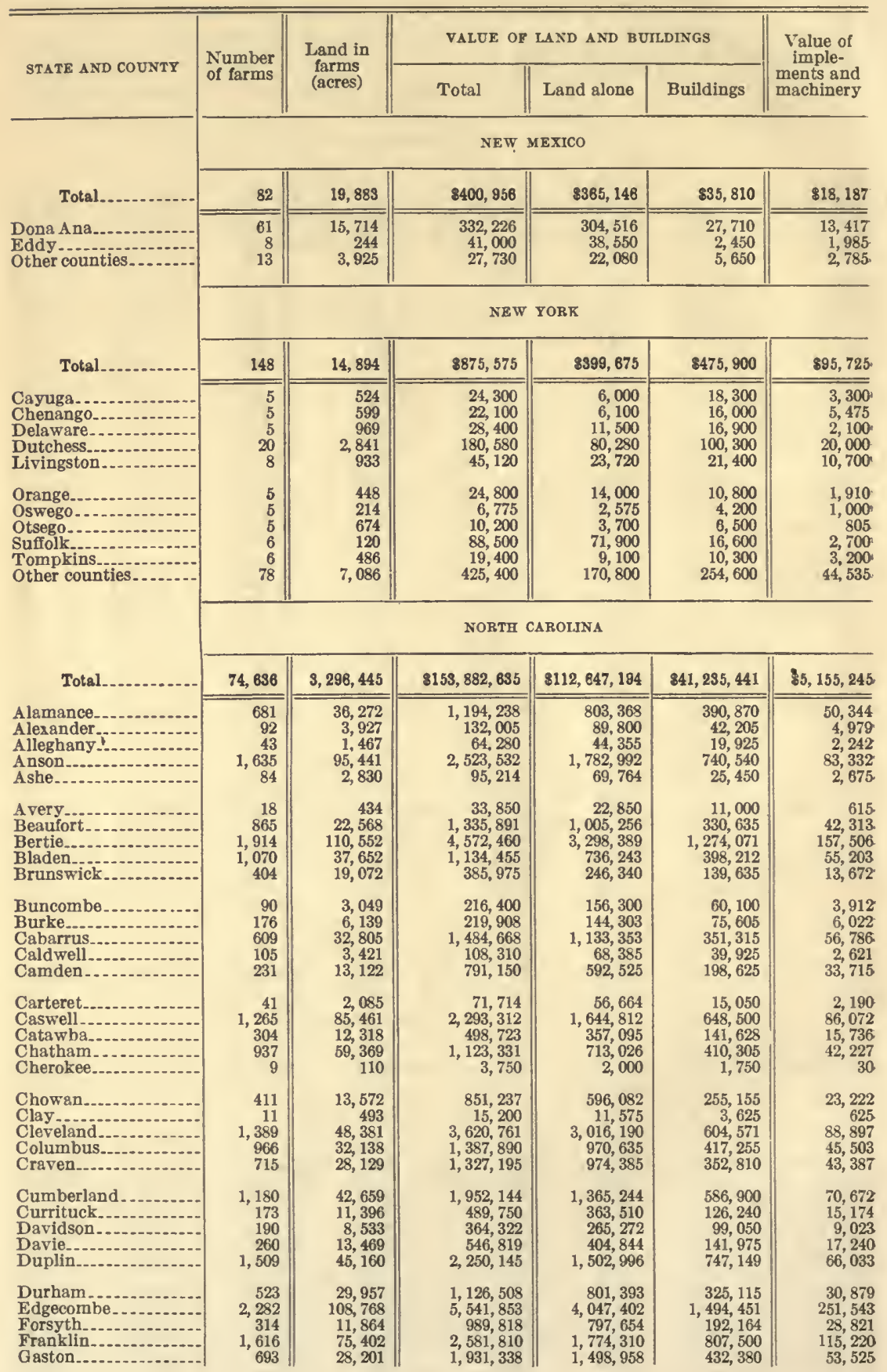


Table 38. -Farms Operated by Negroes-Number, Acreage, and Value of Specified Classes of Farm Property, by States and Counties, 1930Continued

\begin{tabular}{|c|c|c|c|c|c|c|}
\hline \multirow{2}{*}{ STATE AND COUNTY } & \multirow{2}{*}{$\begin{array}{l}\text { Number } \\
\text { of farms }\end{array}$} & \multirow{2}{*}{$\begin{array}{l}\text { Land in } \\
\text { farms } \\
\text { (acres) }\end{array}$} & \multicolumn{3}{|c|}{ VALUE OF LAND AND BUILDINGS } & \multirow{2}{*}{$\begin{array}{l}\text { Value of } \\
\text { imple- } \\
\text { ments and } \\
\text { machinery }\end{array}$} \\
\hline & & & Total & Land alone & Buildings & \\
\hline & \multicolumn{6}{|c|}{ NORTH CAROLINA-continued } \\
\hline $\begin{array}{l}\text { Gates } \\
\text { Granville } \\
\text { Greene } \\
\text { Guilford. } \\
\text { Halifax }\end{array}$ & $\begin{array}{r}538 \\
1,575 \\
1,473 \\
554 \\
3,305\end{array}$ & $\begin{array}{r}27,215 \\
91,393 \\
42,193 \\
24,984 \\
181,827\end{array}$ & $\begin{array}{r}\$ 950,737 \\
2,663,593 \\
3,544,346 \\
1,408,282 \\
7,006,530\end{array}$ & $\begin{array}{r}\$ 663,027 \\
1,775,848 \\
2,657,088 \\
1,013,792 \\
5,117,396\end{array}$ & $\begin{array}{r}\$ 287,710 \\
887,745 \\
887,258 \\
394,490 \\
1,889,134\end{array}$ & $\begin{array}{r}\$ 29,751 \\
108,824 \\
90,239 \\
35,765 \\
362,935\end{array}$ \\
\hline $\begin{array}{l}\text { Harnett. } \\
\text { Haywood. } \\
\text { Henderson } \\
\text { Hertford. } \\
\text { Hoke }\end{array}$ & $\begin{array}{r}910 \\
9 \\
59 \\
1,205 \\
1,145\end{array}$ & $\begin{array}{r}32,730 \\
344 \\
2,020 \\
75,393 \\
46,087\end{array}$ & $\begin{array}{r}1,848,032 \\
20,700 \\
116,661 \\
3,192,490 \\
3,078,680\end{array}$ & $\begin{array}{r}1,337,312 \\
14,218 \\
87,711 \\
2,436,220 \\
2,432,255\end{array}$ & $\begin{array}{r}510,720 \\
6,482 \\
28,950 \\
756,270 \\
646,425\end{array}$ & $\begin{array}{r}65,930 \\
1,450 \\
4,114 \\
93,706 \\
77,547\end{array}$ \\
\hline $\begin{array}{l}\text { Hyde } \\
\text { Iredell_l } \\
\text { Jackson } \\
\text { Johnston. } \\
\text { Jones. }\end{array}$ & $\begin{array}{r}336 \\
762 \\
52 \\
1,252 \\
610\end{array}$ & $\begin{array}{r}10,989 \\
34,203 \\
1,530 \\
51,101 \\
29,296\end{array}$ & $\begin{array}{r}574,953 \\
1,417,050 \\
66,460 \\
2,938,317 \\
1,076,105\end{array}$ & $\begin{array}{r}484,319 \\
1,086,322 \\
44,905 \\
2,162,488 \\
763,620\end{array}$ & $\begin{array}{r}90,639 \\
330,728 \\
21,555 \\
775,829 \\
312,485\end{array}$ & $\begin{array}{r}20,580 \\
40,679 \\
1,307 \\
101,285 \\
46,311\end{array}$ \\
\hline $\begin{array}{l}\text { Leenoir } \\
\text { Lincoln } \\
\text { M cDowell } \\
\text { Macon }\end{array}$ & $\begin{array}{r}450 \\
1,559 \\
399 \\
63 \\
43\end{array}$ & $\begin{array}{r}18,458 \\
56,158 \\
14,322 \\
3,344 \\
1,334\end{array}$ & $\begin{array}{r}702,935 \\
4,117,110 \\
698,088 \\
84,270 \\
41,550\end{array}$ & $\begin{array}{r}488,225 \\
3,083,195 \\
550,768 \\
57,385 \\
30,050\end{array}$ & $\begin{array}{r}214,710 \\
1,033,915 \\
147,320 \\
26,885 \\
11,500\end{array}$ & $\begin{array}{r}28,011 \\
124,166 \\
17,537 \\
2,960 \\
1,046\end{array}$ \\
\hline $\begin{array}{l}\text { Madison } \\
\text { Martin } \\
\text { Mecklenburg } \\
\text { Mitchell_... } \\
\text { Montgomery }\end{array}$ & $\begin{array}{r}22 \\
1,043 \\
1,360 \\
6 \\
324\end{array}$ & $\begin{array}{r}239 \\
46,057 \\
61,657 \\
185 \\
15,247\end{array}$ & $\begin{array}{r}16,500 \\
2,289,920 \\
4,482,941 \\
4,250 \\
386,366\end{array}$ & $\begin{array}{r}11,225 \\
1,697,265 \\
3,825,819 \\
3,130 \\
272,039\end{array}$ & $\begin{array}{r}5,275 \\
592,655 \\
657,122 \\
1,120 \\
114,327\end{array}$ & $\begin{array}{r}235 \\
65,675 \\
67,785 \\
84 \\
12,450\end{array}$ \\
\hline $\begin{array}{l}\text { Moore } \\
\text { Nash } \\
\text { New Hanover... } \\
\text { Northampton } \\
\text { Onslow ... }\end{array}$ & $\begin{array}{r}433 \\
2,575 \\
48 \\
2,442 \\
518\end{array}$ & $\begin{array}{r}21,566 \\
96,797 \\
1,933 \\
110,452 \\
20,976\end{array}$ & $\begin{array}{r}729,804 \\
5,746,500 \\
138,825 \\
5,642,535 \\
813,631\end{array}$ & $\begin{array}{r}477,689 \\
4,153,515 \\
109,040 \\
4,369,398 \\
589,651\end{array}$ & $\begin{array}{r}252,115 \\
1,592,985 \\
29,785 \\
1,273,137 \\
223,980\end{array}$ & $\begin{array}{r}24,636 \\
199,274 \\
5,650 \\
222,250 \\
24,464\end{array}$ \\
\hline $\begin{array}{l}\text { Orange } \\
\text { Pamlico } \\
\text { Pasquotank } \\
\text { Pender............... } \\
\text { Perquimans..... }\end{array}$ & $\begin{array}{l}491 \\
203 \\
427 \\
845 \\
438\end{array}$ & $\begin{array}{r}33,790 \\
6,534 \\
16,732 \\
24,086 \\
22,601\end{array}$ & $\begin{array}{r}782,220 \\
285,989 \\
1,125,800 \\
-\quad 865,579 \\
1,078,805\end{array}$ & $\begin{array}{l}498,899 \\
225,453 \\
909,860 \\
494,105 \\
788,160\end{array}$ & $\begin{array}{r}283,321 \\
60,535 \\
215,940 \\
371,474 \\
290,645\end{array}$ & $\begin{array}{r}38,367 \\
5,842 \\
29,526 \\
41,872 \\
32,011\end{array}$ \\
\hline $\begin{array}{l}\text { Person } \\
\text { Pitt } \\
\text { Polk } \\
\text { Randolph } \\
\text { Richmond }\end{array}$ & $\begin{array}{r}1,173 \\
2,985 \\
137 \\
324 \\
821\end{array}$ & $\begin{array}{r}60,688 \\
92,120 \\
8,615 \\
17,695 \\
50,076\end{array}$ & $\begin{array}{r}1,751,626 \\
7,383,278 \\
318,096 \\
446,675 \\
1,593,843\end{array}$ & $\begin{array}{r}1,174,554 \\
5,181,388 \\
251,191 \\
269,040 \\
1,130,243\end{array}$ & $\begin{array}{r}577,072 \\
2,201,890 \\
66,905 \\
177,635 \\
463,600\end{array}$ & $\begin{array}{r}59,317 \\
290,221 \\
5,823 \\
23,121 \\
44,621\end{array}$ \\
\hline $\begin{array}{l}\text { Robeson } \\
\text { Rockingham } \\
\text { Rowan } \\
\text { Rutherford.... } \\
\text { Sampson }\end{array}$ & $\begin{array}{r}2,685 \\
834 \\
614 \\
492 \\
1,719\end{array}$ & $\begin{array}{l}92,954 \\
44,251 \\
27,819 \\
25,418 \\
70,233\end{array}$ & $\begin{array}{l}5,576,296 \\
1,462,317 \\
1,455,850 \\
1,049,377 \\
2,832,626\end{array}$ & $\begin{array}{r}4,211,756 \\
1,069,587 \\
1,069,030 \\
759,309 \\
2,010,579\end{array}$ & $\begin{array}{r}1,364,540 \\
392,730 \\
336,820 \\
290,068 \\
822,047\end{array}$ & $\begin{array}{r}145,954 \\
43,520 \\
48,578 \\
36,893 \\
81,947\end{array}$ \\
\hline $\begin{array}{l}\text { Scotland } \\
\text { Stanly } \\
\text { Stokes } \\
\text { Surry }\end{array}$ & $\begin{array}{r}1,211 \\
158 \\
295 \\
206 \\
5\end{array}$ & $\begin{array}{r}54,185 \\
8,359 \\
14,684 \\
8,247 \\
664\end{array}$ & $\begin{array}{r}3,410,910 \\
245,400 \\
498,312 \\
401,288 \\
11,900\end{array}$ & $\begin{array}{r}2,753,235 \\
182,575 \\
345,657 \\
286,023 \\
8,650\end{array}$ & $\begin{array}{r}657,675 \\
62,825 \\
152,655 \\
115,265 \\
3,250\end{array}$ & $\begin{array}{r}64,109 \\
5,623 \\
16,102 \\
10,463 \\
300\end{array}$ \\
\hline $\begin{array}{l}\text { Tyrrell } \\
\text { Union } \\
\text { Vance } \\
\text { Wake } \\
\text { Warren }\end{array}$ & $\begin{array}{r}97 \\
1,178 \\
1,153 \\
2,244 \\
1,896\end{array}$ & $\begin{array}{r}4,335 \\
49,888 \\
56,559 \\
98,638 \\
90,973\end{array}$ & $\begin{array}{r}160,951 \\
1,865,417 \\
2,102,099 \\
4,517,850 \\
2,560,040\end{array}$ & $\begin{array}{r}122,841 \\
1,319,489 \\
1,428,819 \\
2,987,160 \\
1,695,003\end{array}$ & $\begin{array}{r}38,110 \\
545,928 \\
673,280 \\
1,530,690 \\
865,037\end{array}$ & $\begin{array}{r}4,894 \\
45,987 \\
95,549 \\
137,650 \\
147,697\end{array}$ \\
\hline $\begin{array}{l}\text { Washington } \\
\text { Watauga........... } \\
\text { Wayne } \\
\text { Wilkes.......... }\end{array}$ & $\begin{array}{r}296 \\
12 \\
1,722 \\
241\end{array}$ & $\begin{array}{r}11,484 \\
620 \\
66,248 \\
9,712\end{array}$ & $\begin{array}{r}489,325 \\
17,075 \\
5,268,914 \\
353,706\end{array}$ & $\begin{array}{r}348,955 \\
13,450 \\
4,025,414 \\
241,751\end{array}$ & $\begin{array}{r}140,370 \\
3,625 \\
1,243,500 \\
111,955\end{array}$ & $\begin{array}{r}12,565 \\
195 \\
128,492 \\
11,592\end{array}$ \\
\hline $\begin{array}{l}\text { Wilson...... } \\
\text { Yadkin } \\
\text { Yancey } \\
\text { Other counties.... }\end{array}$ & $\begin{array}{r}1,725 \\
114 \\
16 \\
4\end{array}$ & $\begin{array}{r}58,194 \\
3,345 \\
328 \\
124\end{array}$ & $\begin{array}{r}4,726,950 \\
167,675 \\
13,125 \\
5,200\end{array}$ & $\begin{array}{r}3,556,243 \\
124,715 \\
8,800 \\
2,075\end{array}$ & $\begin{array}{r}1,170,707 \\
42,960 \\
4,325 \\
3,125\end{array}$ & $\begin{array}{r}139,670 \\
7,713 \\
349 \\
80\end{array}$ \\
\hline
\end{tabular}


Table 38.-Farms Operated by Negroes-Number, Acreage, and Value of Specified Classes of Farm Property, by States and Codnties, 1930Continued

\begin{tabular}{|c|c|c|c|c|c|c|}
\hline \multirow{2}{*}{ STATE AND COUNTY } & \multirow{2}{*}{$\begin{array}{l}\text { Number } \\
\text { of farms }\end{array}$} & \multirow{2}{*}{$\begin{array}{l}\text { Land in } \\
\text { farms } \\
\text { (acres) }\end{array}$} & \multicolumn{3}{|c|}{ VALUE OF LAND AND BUILDINGS } & \multirow{2}{*}{$\begin{array}{l}\text { Value of } \\
\text { imple- } \\
\text { ments and } \\
\text { machinery. }\end{array}$} \\
\hline & & & Total & Land aione & Builidings & \\
\hline \multirow{3}{*}{ Total } & \multicolumn{6}{|c|}{ NORTH DAKOTA } \\
\hline & 10 & 2,565 & 862,700 & $\$ 47,300$ & 815,400 & 87,873 \\
\hline & \multicolumn{6}{|c|}{ онІо } \\
\hline Total. & 1,229 & 92,083 & $85,434,735$ & $\$ 3,671,445$ & $81,863,290$ & 8217,018 \\
\hline $\begin{array}{l}\text { Adams... } \\
\text { Allen } \\
\text { Ashtabula } \\
\text { A thens } \\
\text { Belmont..... }\end{array}$ & $\begin{array}{r}6 \\
5 \\
7 \\
25 \\
27\end{array}$ & $\begin{array}{r}552 \\
257 \\
155 \\
1,860 \\
1,360\end{array}$ & $\begin{array}{l}18,700 \\
27,900 \\
26,100 \\
57,100 \\
75,700\end{array}$ & $\begin{array}{r}12,700 \\
19,600 \\
9,900 \\
28,430 \\
43,100\end{array}$ & $\begin{array}{r}6,000 \\
8,300 \\
16,200 \\
28,670 \\
32,600\end{array}$ & $\begin{array}{r}935 \\
470 \\
1,225 \\
2,333 \\
2,963\end{array}$ \\
\hline $\begin{array}{l}\text { Brown } \\
\text { Butier } \\
\text { Champaign } \\
\text { Clark } \\
\text { Clermont.... }\end{array}$ & $\begin{array}{l}68 \\
10 \\
40 \\
35 \\
45\end{array}$ & $\begin{array}{l}3,206 \\
1,584 \\
4,714 \\
2,486 \\
2,427\end{array}$ & $\begin{array}{l}162,030 \\
195,600 \\
296,860 \\
198,670 \\
177,580\end{array}$ & $\begin{array}{r}96,220 \\
123,250 \\
195,460 \\
131,745 \\
102,830\end{array}$ & $\begin{array}{r}65,810 \\
72,350 \\
101,400 \\
66,925 \\
74,750\end{array}$ & $\begin{array}{r}4,780 \\
5,270 \\
11,670 \\
4,205 \\
3,600\end{array}$ \\
\hline $\begin{array}{l}\text { Clinton } \\
\text { Columbiana } \\
\text { Darke } \\
\text { Delaware } \\
\text { Fayette...... }\end{array}$ & $\begin{array}{r}18 \\
10 \\
34 \\
12 \\
7\end{array}$ & $\begin{array}{l}1,418 \\
697 \\
2,347 \\
1,124 \\
1,053\end{array}$ & $\begin{array}{r}81,080 \\
36,610 \\
138,860 \\
82,650 \\
63,150\end{array}$ & $\begin{array}{l}45,680 \\
16,960 \\
82,560 \\
50,850 \\
48,400\end{array}$ & $\begin{array}{l}35,400 \\
19,650 \\
56,300 \\
31,800 \\
14,750\end{array}$ & $\begin{array}{r}3,665 \\
805 \\
7,945 \\
1,260 \\
1,840\end{array}$ \\
\hline $\begin{array}{l}\text { Franklin } \\
\text { Fulton } \\
\text { Gallia } \\
\text { Greene } \\
\text { Guernsey.... } \\
\end{array}$ & $\begin{array}{r}27 \\
5 \\
84 \\
58 \\
6\end{array}$ & $\begin{array}{r}1,090 \\
101 \\
4,427 \\
3,495 \\
466\end{array}$ & $\begin{array}{r}285,340 \\
22,300 \\
103,220 \\
357,235 \\
20,000\end{array}$ & $\begin{array}{r}214,860 \\
8,500 \\
62,095 \\
210,015 \\
15,450\end{array}$ & $\begin{array}{r}70,480 \\
13,800 \\
41,125 \\
147,220 \\
4,550\end{array}$ & $\begin{array}{r}6,540 \\
900 \\
6,620 \\
23,305 \\
775\end{array}$ \\
\hline $\begin{array}{l}\text { Hamilton } \\
\text { Hardin } \\
\text { Harrison } \\
\text { Highiand } \\
\text { Hocking }\end{array}$ & $\begin{array}{r}8 \\
11 \\
18 \\
17 \\
5\end{array}$ & $\begin{array}{r}319 \\
941 \\
1,384 \\
1,188 \\
747\end{array}$ & $\begin{array}{l}53,190 \\
56,100 \\
37,195 \\
61,400 \\
27,150\end{array}$ & $\begin{array}{l}41,890 \\
35,525 \\
19,495 \\
39,875 \\
23,300\end{array}$ & $\begin{array}{r}11,300 \\
20,575 \\
17,700 \\
21,525 \\
3,850\end{array}$ & $\begin{array}{l}1,642 \\
1,760 \\
1,560 \\
3,160 \\
1,270\end{array}$ \\
\hline $\begin{array}{l}\text { Jackson } \\
\text { Jefferson } \\
\text { Lawrence } \\
\text { Logan } \\
\text { Loraln } . . . \\
\end{array}$ & $\begin{array}{r}36 \\
19 \\
33 \\
21 \\
9\end{array}$ & $\begin{array}{l}2,745 \\
1,580 \\
1,228 \\
1,304 \\
203\end{array}$ & $\begin{array}{l}86,775 \\
67,800 \\
85,800 \\
81,950 \\
33,050\end{array}$ & $\begin{array}{l}53,525 \\
44,075 \\
55,200 \\
43,625 \\
14,850\end{array}$ & $\begin{array}{l}33,250 \\
23,725 \\
30,600 \\
38,325 \\
18,200\end{array}$ & $\begin{array}{l}5,210 \\
1,890 \\
2,370 \\
2,380 \\
950\end{array}$ \\
\hline $\begin{array}{l}\text { Madison } \\
\text { Mahoning } \\
\text { Meigs_... } \\
\text { Mercer } \\
\text { Mlami }\end{array}$ & $\begin{array}{r}30 \\
5 \\
29 \\
5 \\
9\end{array}$ & $\begin{array}{r}4,569 \\
359 \\
749 \\
312 \\
395\end{array}$ & $\begin{array}{r}248,300 \\
34,850 \\
38,090 \\
21,100 \\
32,560\end{array}$ & $\begin{array}{r}199,560 \\
17,700 \\
21,930 \\
16,400 \\
18,910\end{array}$ & $\begin{array}{r}48,740 \\
17,150 \\
16,160 \\
4,700 \\
13,650\end{array}$ & $\begin{array}{l}7,785 \\
2,740 \\
1,540 \\
1,100 \\
2,385\end{array}$ \\
\hline $\begin{array}{l}\text { Monroe } \\
\text { Montgomery } \\
\text { Morgan } \\
\text { Muskingum } \\
\text { Paulding.......... }\end{array}$ & $\begin{array}{r}5 \\
8 \\
32 \\
14 \\
26\end{array}$ & $\begin{array}{r}187 \\
339 \\
1,989 \\
889 \\
3,270\end{array}$ & $\begin{array}{r}6,120 \\
45,000 \\
50,975 \\
63,700 \\
225,450\end{array}$ & $\begin{array}{r}4,970 \\
24,300 \\
30,845 \\
52,500 \\
159,050\end{array}$ & $\begin{array}{r}1,150 \\
20,700 \\
20,130 \\
11,200 \\
66,400\end{array}$ & $\begin{array}{r}0 \\
1,290 \\
1,735 \\
775 \\
12,300\end{array}$ \\
\hline $\begin{array}{l}\text { Pickaway } \\
\text { Pike } \\
\text { Preble } \\
\text { Ross }\end{array}$ & $\begin{array}{r}16 \\
49 \\
8 \\
60\end{array}$ & $\begin{array}{r}3,065 \\
5,021 \\
736 \\
5,767\end{array}$ & $\begin{array}{r}192,360 \\
144,400 \\
41,410 \\
320,530\end{array}$ & $\begin{array}{r}156,660 \\
116,735 \\
26,210 \\
255,655\end{array}$ & $\begin{array}{l}35,700 \\
27,665 \\
15,200 \\
64,875\end{array}$ & $\begin{array}{r}8,330 \\
7,060 \\
1,945 \\
14,220\end{array}$ \\
\hline $\begin{array}{l}\text { Shelby } \\
\text { Stark } \\
\text { Union } \\
\text { Van Wert }\end{array}$ & $\begin{array}{l}6 \\
7 \\
6 \\
5\end{array}$ & $\begin{array}{l}412 \\
256 \\
420 \\
325\end{array}$ & $\begin{array}{l}19,100 \\
34,500 \\
29,180 \\
25,400\end{array}$ & $\begin{array}{l}13,900 \\
22,200 \\
12,980 \\
15,100\end{array}$ & $\begin{array}{r}5,200 \\
12,300 \\
16,200 \\
10,300\end{array}$ & $\begin{array}{r}650 \\
1,900 \\
1,450 \\
550\end{array}$ \\
\hline $\begin{array}{l}\text { Vinton } \\
\text { Warren } \\
\text { Washingtoon } \\
\text { Other counties....... }\end{array}$ & $\begin{array}{r}8 \\
28 \\
100 \\
67\end{array}$ & $\begin{array}{r}375 \\
2,137 \\
9,396 \\
4,657\end{array}$ & $\begin{array}{r}7,200 \\
151,480 \\
246,515 \\
439,420\end{array}$ & $\begin{array}{r}4,700 \\
100,380 \\
154,675 \\
256,120\end{array}$ & $\begin{array}{r}2,500 \\
51,100 \\
91,840 \\
183,300\end{array}$ & $\begin{array}{r}175 \\
6,335 \\
13,705 \\
15,665\end{array}$ \\
\hline
\end{tabular}


Table 38. - Farms Operated by Negroes-Number, Acreage, and Valde of Specified Classes of Farm Property, by States and Counties, 1930Continued

\begin{tabular}{|c|c|c|c|c|c|c|}
\hline \multirow{2}{*}{ STATE $\triangle N D$ COUNTY } & \multirow{2}{*}{$\begin{array}{l}\text { Number } \\
\text { of farms }\end{array}$} & \multirow{2}{*}{$\begin{array}{l}\text { Land in } \\
\text { farms } \\
\text { (acres) }\end{array}$} & \multicolumn{3}{|c|}{ VALUE OF LAND AND BUILDINGS } & \multirow{2}{*}{$\begin{array}{l}\text { Value of } \\
\text { imple- } \\
\text { ments and } \\
\text { machinery }\end{array}$} \\
\hline & & & Total & Land alone & Buildings & \\
\hline & \multicolumn{5}{|c|}{ ОКLАНОMА } & $\cdot$ \\
\hline Total & 15,172 & $1,061,341$ & $887,867,118$ & $882,278,827$ & $85,687,186$ & $81,595,879$ \\
\hline $\begin{array}{l}\text { Atoka } \\
\text { Beckham } \\
\text { Blaine } \\
\text { Bryan } \\
\text { Caddo }\end{array}$ & $\begin{array}{r}117 \\
47 \\
232 \\
182 \\
158\end{array}$ & $\begin{array}{r}7,685 \\
4,164 \\
23,036 \\
12,171 \\
11,767\end{array}$ & $\begin{array}{l}163,530 \\
180,305 \\
842,380 \\
315,695 \\
476,692\end{array}$ & $\begin{array}{l}125,320 \\
166,285 \\
738,215 \\
269,430 \\
429,942\end{array}$ & $\begin{array}{r}38,210 \\
14,020 \\
104,165 \\
46,265 \\
46,750\end{array}$ & $\begin{array}{r}8,833 \\
10,635 \\
60,700 \\
14,211 \\
17,154\end{array}$ \\
\hline $\begin{array}{l}\text { Canadian } \\
\text { Carter } \\
\text { Cherokee } \\
\text { Choctaw } \\
\text { Cleveland }\end{array}$ & $\begin{array}{r}71 \\
230 \\
89 \\
800 \\
25\end{array}$ & $\begin{array}{r}4,565 \\
16,547 \\
5,744 \\
41,266 \\
4,997\end{array}$ & $\begin{array}{r}242,500 \\
399,163 \\
122,335 \\
1,106,544 \\
65,710\end{array}$ & $\begin{array}{r}217,925 \\
319,360 \\
96,395 \\
929,048 \\
58,910\end{array}$ & $\begin{array}{r}24,575 \\
79,803 \\
25,940 \\
177,496 \\
6,800\end{array}$ & $\begin{array}{r}8,555 \\
23,565 \\
3,967 \\
53,384 \\
2,490\end{array}$ \\
\hline $\begin{array}{l}\text { Coal } \\
\text { Comanche... } \\
\text { Cotton } \\
\text { Craig }\end{array}$ & $\begin{array}{r}64 \\
43 \\
44 \\
60 \\
773\end{array}$ & $\begin{array}{r}7,085 \\
4,227 \\
3,309 \\
6,273 \\
63,971\end{array}$ & $\begin{array}{r}121,305 \\
105,312 \\
108,390 \\
133,430 \\
1,849,270\end{array}$ & $\begin{array}{r}93,755 \\
90,890 \\
95,625 \\
111,715 \\
1,578,335\end{array}$ & $\begin{array}{r}27,550 \\
14,422 \\
12,765 \\
21,715 \\
270,935\end{array}$ & $\begin{array}{r}7,590 \\
6,015 \\
6,995 \\
3,948 \\
82,306\end{array}$ \\
\hline $\begin{array}{l}\text { Custer } \\
\text { Dewey...... } \\
\text { Garfield..... } \\
\text { Garvin } \\
\text { Grady....... }\end{array}$ & $\begin{array}{r}31 \\
5 \\
20 \\
157 \\
77\end{array}$ & $\begin{array}{r}2,480 \\
685 \\
2,375 \\
12,252 \\
4,598\end{array}$ & $\begin{array}{r}104,575 \\
16,300 \\
108,750 \\
326,570 \\
264,325\end{array}$ & $\begin{array}{r}93,685 \\
14,100 \\
95,625 \\
276,310 \\
242,565\end{array}$ & $\begin{array}{r}10,890 \\
2,200 \\
13,125 \\
50,260 \\
21,760\end{array}$ & $\begin{array}{r}7,550 \\
500 \\
5,685 \\
11,913 \\
14,425\end{array}$ \\
\hline $\begin{array}{l}\text { Greer........ } \\
\text { Harmon..... } \\
\text { Haskell..... } \\
\text { Hughes...... } \\
\text { Jackson..... }\end{array}$ & $\begin{array}{r}65 \\
17 \\
29 \\
196 \\
30\end{array}$ & $\begin{array}{r}4,194 \\
731 \\
1,812 \\
15,861 \\
2,033\end{array}$ & $\begin{array}{r}212,980 \\
33,740 \\
36,050 \\
620,785 \\
126,050\end{array}$ & $\begin{array}{r}191,739 \\
30,050 \\
28,000 \\
540,580 \\
117,650\end{array}$ & $\begin{array}{r}21,241 \\
3,690 \\
8,050 \\
80,205 \\
8,400\end{array}$ & $\begin{array}{r}11,120 \\
1,235 \\
1,380 \\
24,257 \\
6,555\end{array}$ \\
\hline $\begin{array}{l}\text { Jefferson } \\
\text { Johnston..... } \\
\text { Klngfisher... } \\
\text { Klowa..... } \\
\text { Latimer..... }\end{array}$ & $\begin{array}{r}7 \\
53 \\
293 \\
113 \\
30\end{array}$ & $\begin{array}{r}660 \\
3,493 \\
31,183 \\
9,031 \\
913\end{array}$ & $\begin{array}{r}22,400 \\
62,625 \\
1,128,700 \\
516,600 \\
19,650\end{array}$ & $\begin{array}{r}20,300 \\
50,275 \\
981,855 \\
484,400 \\
13,615\end{array}$ & $\begin{array}{r}2,100 \\
12,350 \\
166,845 \\
32,200 \\
6,035\end{array}$ & $\begin{array}{r}425 \\
3,045 \\
59,635 \\
30,015 \\
2,155\end{array}$ \\
\hline $\begin{array}{l}\text { Le Flore.... } \\
\text { Lincoln..... } \\
\text { Logan } \\
\text { Love } \\
\text { McClain........ }\end{array}$ & $\begin{array}{r}158 \\
442 \\
809 \\
91 \\
80\end{array}$ & $\begin{array}{r}7,686 \\
42,386 \\
86,141 \\
5,678 \\
4,158\end{array}$ & $\begin{array}{r}286,522 \\
1,399,940 \\
3,365,642 \\
117,890 \\
186,492\end{array}$ & $\begin{array}{r}228,575 \\
1,193,710 \\
2,838,017 \\
96,580 \\
151,232\end{array}$ & $\begin{array}{r}57,947 \\
206,230 \\
527,625 \\
21,310 \\
35,260\end{array}$ & $\begin{array}{r}8,315 \\
51,440 \\
110,454 \\
6,512 \\
11,049\end{array}$ \\
\hline $\begin{array}{l}\text { MeCurtain } \\
\text { MeIntosh } \\
\text { Major } \\
\text { Marshall } \\
\text { Mayes.... }\end{array}$ & $\begin{array}{r}1,290 \\
674 \\
8 \\
7 \\
106\end{array}$ & $\begin{array}{r}48,004 \\
46,407 \\
2,354 \\
285 \\
6,057\end{array}$ & $\begin{array}{r}2,091,559 \\
1,150,868 \\
.75,000 \\
5,609 \\
261,250\end{array}$ & $\begin{array}{r}1,745,875 \\
927,873 \\
66,700 \\
4,409 \\
216,175\end{array}$ & $\begin{array}{r}345,684 \\
222,995 \\
8,300 \\
1,200 \\
45,075\end{array}$ & $\begin{array}{r}90,771 \\
47,728 \\
6,780 \\
220 \\
7,887\end{array}$ \\
\hline $\begin{array}{l}\text { Murray } \\
\text { Muskogee. } \\
\text { Noble } \\
\text { Nowata } \\
\text { Okfuskee-. }\end{array}$ & $\begin{array}{r}17 \\
1,349 \\
76 \\
199 \\
1,172\end{array}$ & $\begin{array}{r}1,341 \\
86,220 \\
7,708 \\
14,564 \\
83,327\end{array}$ & $\begin{array}{r}28,190 \\
3,579,411 \\
309,295 \\
364,990 \\
3,281,373\end{array}$ & $\begin{array}{r}25,440 \\
2,937,386 \\
272,195 \\
309,400 \\
2,729,653\end{array}$ & $\begin{array}{r}2,750 \\
642,025 \\
37,100 \\
55,590 \\
551,720\end{array}$ & $\begin{array}{r}1,305 \\
154,617 \\
11,238 \\
15,994 \\
146,296\end{array}$ \\
\hline $\begin{array}{l}\text { Oklahoma } \\
\text { Okmulgee } \\
\text { Osage } \\
\text { Pawnee. } \\
\text { Payne.... }\end{array}$ & $\begin{array}{r}381 \\
1,347 \\
24 \\
95 \\
185\end{array}$ & $\begin{array}{r}39,708 \\
88,788 \\
2,007 \\
6,582 \\
15,098\end{array}$ & $\begin{array}{r}1,566,690 \\
2,805,310 \\
69,835 \\
199,135 \\
612,030\end{array}$ & $\begin{array}{r}1,341,095 \\
2,474,017 \\
51,385 \\
174,285 \\
547,126\end{array}$ & $\begin{array}{r}225,595 \\
331,293 \\
18,450 \\
24,850 \\
64,904\end{array}$ & $\begin{array}{r}54,512 \\
103,139 \\
3,100 \\
7,995 \\
15,075\end{array}$ \\
\hline $\begin{array}{l}\text { Pittsburg } \\
\text { Pontotoc } \\
\text { Pottawatomie } \\
\text { Pushmataha } \\
\text { Roger Mills........ }\end{array}$ & $\begin{array}{r}154 \\
72 \\
94 \\
38 \\
8\end{array}$ & $\begin{array}{l}8,339 \\
4,010 \\
8,130 \\
2,308 \\
1,505\end{array}$ & $\begin{array}{r}230,454 \\
108,810 \\
231,060 \\
31,530 \\
33,450\end{array}$ & $\begin{array}{r}171,127 \\
89,965 \\
184,210 \\
21,760 \\
31,275\end{array}$ & $\begin{array}{r}59,327 \\
18,845 \\
46,850 \\
9,770 \\
2,175\end{array}$ & $\begin{array}{r}7,258 \\
4,615 \\
10,373 \\
2,023 \\
1,976\end{array}$ \\
\hline $\begin{array}{l}\text { Rogers } \\
\text { Seminole.. } \\
\text { Sequoyah } \\
\text { Stephens. } \\
\text { Tillman }\end{array}$ & $\begin{array}{r}49 \\
450 \\
253 \\
9 \\
129\end{array}$ & $\begin{array}{r}3,266 \\
32,154 \\
10,385 \\
1,170 \\
7,133\end{array}$ & $\begin{array}{r}133,185 \\
1,363,723 \\
454,441 \\
28,900 \\
421,125\end{array}$ & $\begin{array}{r}112,795 \\
1,157,633 \\
378,496 \\
25,890 \\
382,650\end{array}$ & $\begin{array}{r}20,390 \\
206,090 \\
75,945 \\
3,010 \\
38,475\end{array}$ & $\begin{array}{r}4,763 \\
67,483 \\
11,491 \\
1,550 \\
26,650\end{array}$ \\
\hline
\end{tabular}


Table 38. - Farms Operated by Negroes-Number, Acreage, and Value of Specified Classes of Farm Property, by States and Counties, 1930Continued

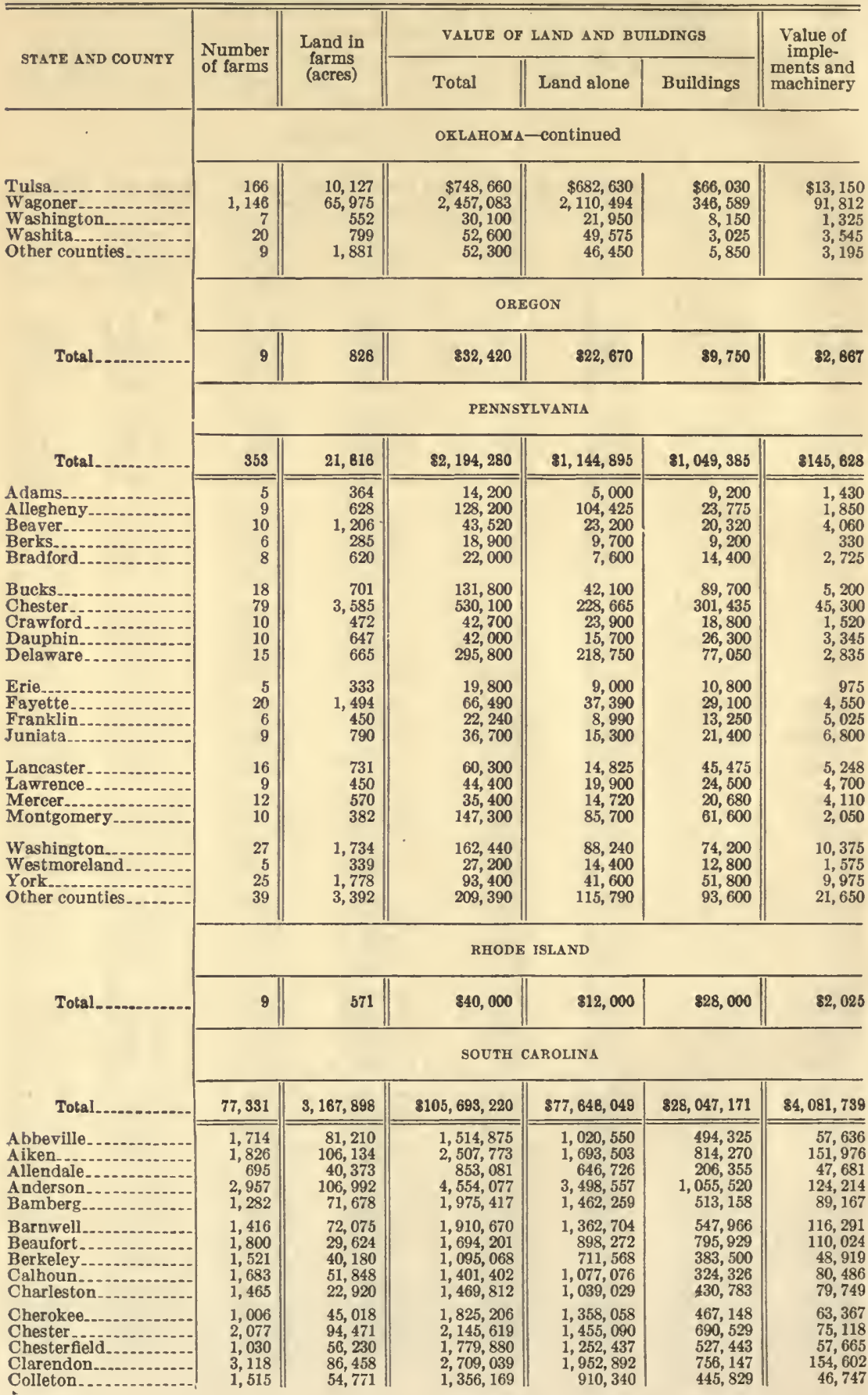


Table 38.-Farms Operated by Negroes-Number, Acreage, and Valde of Specified Classes of Farm Property, by States and Counties, 1930Continued

\begin{tabular}{|c|c|c|c|c|c|c|}
\hline \multirow{2}{*}{ STATE AND COUNTY } & \multirow{2}{*}{$\begin{array}{l}\text { Number } \\
\text { of farms }\end{array}$} & \multirow{2}{*}{$\begin{array}{l}\text { Land in } \\
\text { farms } \\
\text { (acres) }\end{array}$} & \multicolumn{3}{|c|}{ VALUE OF LAND AND BUILDINGS } & \multirow{2}{*}{$\begin{array}{l}\text { Value of } \\
\text { imple- } \\
\text { ments and } \\
\text { machinery }\end{array}$} \\
\hline & & & Total & Land alone & Buildings & \\
\hline & \multicolumn{6}{|c|}{ SOUTH CAROLINA-continued } \\
\hline $\begin{array}{l}\text { Darlington } \\
\text { Dillon- } \\
\text { Dorchester } \\
\text { Edgefield } \\
\text { Fairfield. }\end{array}$ & $\begin{array}{l}1,748 \\
1,466 \\
1,028 \\
1,749 \\
1,724\end{array}$ & $\begin{array}{l}76,424 \\
55,407 \\
40,082 \\
87,900 \\
92,075\end{array}$ & $\begin{array}{r}\$ 3,297,461 \\
3,539,624 \\
904,645 \\
2,358,808 \\
1,755,720\end{array}$ & $\begin{array}{r}\$ 2,483,816 \\
2,737,649 \\
580,330 \\
1,687,055 \\
1,093,850\end{array}$ & $\begin{array}{l}\$ 813,645 \\
801,975 \\
324,315 \\
671,753 \\
661,870\end{array}$ & $\begin{array}{r}\$ 72,899 \\
66,509 \\
30,146 \\
115,077 \\
74,085\end{array}$ \\
\hline $\begin{array}{l}\text { Florence } \\
\text { Georgetown } \\
\text { Greenville } \\
\text { Greenwood........... } \\
\text { Hampton }\end{array}$ & $\begin{array}{r}2,207 \\
535 \\
1,988 \\
1,917 \\
708\end{array}$ & $\begin{array}{r}84,325 \\
19,577 \\
71,907 \\
106,386 \\
26,980\end{array}$ & $\begin{array}{r}2,939,970 \\
388,755 \\
4,842,477 \\
2,587,380 \\
575,908\end{array}$ & $\begin{array}{r}2,065,663 \\
204,484 \\
3,785,828 \\
1,778,996 \\
390,438\end{array}$ & $\begin{array}{r}874,307 \\
184,271 \\
1,056,649 \\
808,384 \\
185,470\end{array}$ & $\begin{array}{r}109,167 \\
11,044 \\
149,854 \\
111,270 \\
39,604\end{array}$ \\
\hline $\begin{array}{l}\text { Horry } \\
\text { Jasper } \\
\text { Kershaw } \\
\text { Lancaster } \\
\text { Laurens... }\end{array}$ & $\begin{array}{r}947 \\
650 \\
1,575 \\
1,253 \\
2,282\end{array}$ & $\begin{array}{r}25,376 \\
22,773 \\
77,828 \\
65,283 \\
121,317\end{array}$ & $\begin{array}{r}1,177,547 \\
535,403 \\
1,780,105 \\
1,473,526 \\
3,033,503\end{array}$ & $\begin{array}{r}853,157 \\
344,683 \\
1,238,440 \\
1,034,256 \\
2,234,458\end{array}$ & $\begin{array}{l}324,390 \\
190,720 \\
541,665 \\
439,270 \\
799,045\end{array}$ & $\begin{array}{r}34,587 \\
48,614 \\
88,296 \\
50,414 \\
147,362\end{array}$ \\
\hline $\begin{array}{l}\text { Lee } \\
\text { Mexington } \\
\text { McCormick } \\
\text { Marion } \\
\text { Marlboro }\end{array}$ & $\begin{array}{l}1,654 \\
754 \\
1,274 \\
1,252 \\
2,147\end{array}$ & $\begin{array}{l}72,758 \\
37,583 \\
86,448 \\
40,521 \\
90,774\end{array}$ & $\begin{array}{l}2,870,004 \\
1,264,439 \\
1,441,344 \\
2,384,782 \\
5,976,932\end{array}$ & $\begin{array}{r}2,264,383 \\
932,191 \\
983,783 \\
1,882,625 \\
4,996,868\end{array}$ & $\begin{array}{l}605,621 \\
332,248 \\
457,561 \\
502,157 \\
980,064\end{array}$ & $\begin{array}{r}103,312 \\
45,777 \\
66,442 \\
79,122 \\
100,838\end{array}$ \\
\hline $\begin{array}{l}\text { Newberry } \\
\text { Oconee } \\
\text { Orangeburg-.... } \\
\text { Pickens_..... } \\
\text { Richland...- }\end{array}$ & $\begin{array}{r}1,784 \\
702 \\
4,693 \\
448 \\
1,561\end{array}$ & $\begin{array}{r}91,920 \\
28,724 \\
158,298 \\
17,478 \\
52,632\end{array}$ & $\begin{array}{l}2,125,877 \\
1,201,511 \\
5,042,511 \\
793,660 \\
1,770,505\end{array}$ & $\begin{array}{r}1,519,197 \\
862,966 \\
3,834,766 \\
607,825 \\
1,286,187\end{array}$ & $\begin{array}{r}606,680 \\
338,545 \\
1,207,745 \\
185,835 \\
484,318\end{array}$ & $\begin{array}{r}86,124 \\
47,569 \\
235,162 \\
21,753 \\
71,430\end{array}$ \\
\hline 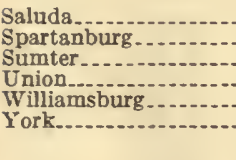 & $\begin{array}{l}1,332 \\
2,623 \\
2,865 \\
1,441 \\
3,043 \\
2,876\end{array}$ & $\begin{array}{r}67,239 \\
101,861 \\
95,762 \\
79,787 \\
88,473 \\
124,015\end{array}$ & $\begin{array}{l}2,069,540 \\
6,154,434 \\
3,878,995 \\
2,027,325 \\
2,261,713 \\
4,446,527\end{array}$ & $\begin{array}{l}1,537,440 \\
4,804,808 \\
2,927,486 \\
1,469,859 \\
1,517,619 \\
3,365,882\end{array}$ & $\begin{array}{r}532,100 \\
1,349,626 \\
951,509 \\
557,466 \\
744,094 \\
1,080,645\end{array}$ & $\begin{array}{r}82,737 \\
231,007 \\
150,941 \\
90,681 \\
91,775 \\
124,499\end{array}$ \\
\hline & \multicolumn{6}{|c|}{ SOUTH DAKOTA } \\
\hline Total... & 40 & 14,228 & 8285,425 & 8225,045 & 860,380 & 832,570 \\
\hline \multirow[t]{2}{*}{$\begin{array}{l}\text { Sully } \\
\text { Other counties........ }\end{array}$} & $\begin{array}{l}10 \\
30\end{array}$ & $\begin{array}{l}4,709 \\
9,519\end{array}$ & $\begin{array}{r}72,420 \\
213,005\end{array}$ & $\begin{array}{r}62,690 \\
162,355\end{array}$ & $\begin{array}{r}9,730 \\
50,650\end{array}$ & $\begin{array}{l}10,050 \\
22,520\end{array}$ \\
\hline & \multicolumn{6}{|c|}{ TENNESSEE } \\
\hline Total. & 35,123 & $1,356,683$ & $856,339,610$ & $842,597,163$ & $813,742,447$ & $82,978,809$ \\
\hline $\begin{array}{l}\text { Anderson. } \\
\text { Bedford } \\
\text { Benton } \\
\text { Bledsoe. } \\
\text { Blount }\end{array}$ & $\begin{array}{r}21 \\
294 \\
21 \\
15 \\
48\end{array}$ & $\begin{array}{r}1,034 \\
15,202 \\
1,277 \\
866 \\
2,406\end{array}$ & $\begin{array}{r}24,675 \\
533,555 \\
17,750 \\
16,000 \\
136,450\end{array}$ & $\begin{array}{r}13,315 \\
385,660 \\
12,475 \\
10,550 \\
89,375\end{array}$ & $\begin{array}{r}11,360 \\
147,895 \\
5,275 \\
5,450 \\
47,075\end{array}$ & $\begin{array}{r}2,487 \\
31,424 \\
1,605 \\
875 \\
12,845\end{array}$ \\
\hline $\begin{array}{l}\text { Bradley } \\
\text { Campbell } \\
\text { Cannon } \\
\text { Carroll } \\
\text { Carter }\end{array}$ & $\begin{array}{r}52 \\
6 \\
33 \\
670 \\
22\end{array}$ & $\begin{array}{r}2,931 \\
271 \\
1,141 \\
31,613 \\
575\end{array}$ & $\begin{array}{r}90,875 \\
8,900 \\
39,030 \\
792,225 \\
\mathbf{4 5}, 630\end{array}$ & $\begin{array}{r}67,075 \\
5,900 \\
29,205 \\
594,961 \\
27,055\end{array}$ & $\begin{array}{r}23,800 \\
3,000 \\
9,825 \\
197,264 \\
18,575\end{array}$ & $\begin{array}{r}6,430 \\
455 \\
2,997 \\
60,495 \\
1,726\end{array}$ \\
\hline $\begin{array}{l}\text { Cheatham } \\
\text { Chester } \\
\text { Claiborne } \\
\text { Clay }\end{array}$ & $\begin{array}{r}90 \\
311 \\
41 \\
13 \\
52\end{array}$ & $\begin{array}{r}3,935 \\
13,721 \\
1,834 \\
829 \\
1,764\end{array}$ & $\begin{array}{r}136,195 \\
416,628 \\
59,775 \\
11,750 \\
73,160\end{array}$ & $\begin{array}{r}100,370 \\
322,343 \\
42,090 \\
8,550 \\
53,085\end{array}$ & $\begin{array}{r}35,825 \\
94,285 \\
17,685 \\
3,200 \\
20,075\end{array}$ & $\begin{array}{r}7,991 \\
31,055 \\
1,738 \\
345 \\
2,339\end{array}$ \\
\hline $\begin{array}{l}\text { Coffee } \\
\text { Crockett } \\
\text { Davidson } \\
\text { Decatur } \\
\text { De Kalb }\end{array}$ & $\begin{array}{r}51 \\
565 \\
264 \\
96 \\
42\end{array}$ & $\begin{array}{r}1,933 \\
18,110 \\
8,983 \\
4,225 \\
1,075\end{array}$ & $\begin{array}{r}35,530 \\
909,587 \\
1,060,146 \\
82,075 \\
48,455\end{array}$ & $\begin{array}{r}23,850 \\
699,312 \\
753,561 \\
61,650 \\
42,330\end{array}$ & $\begin{array}{r}11,680 \\
210,275 \\
306,585 \\
20,425 \\
6,125\end{array}$ & $\begin{array}{r}2,293 \\
44,380 \\
37,689 \\
4,506 \\
1,232\end{array}$ \\
\hline
\end{tabular}


Table 38.-Farms Operated by Negroes-Number, Acreage, and Value of Specified Classes of Farm Property, by States and Counties, 1930Continued

\begin{tabular}{|c|c|c|c|c|c|c|}
\hline \multirow{2}{*}{ STATE AND COUNTY } & \multirow{2}{*}{$\begin{array}{l}\text { Number } \\
\text { of farms }\end{array}$} & \multirow{2}{*}{$\begin{array}{l}\text { Land in } \\
\text { farms } \\
\text { (acres) }\end{array}$} & \multicolumn{3}{|c|}{ VALUE OF LAND AND BUILDINGS } & \multirow{2}{*}{$\begin{array}{l}\text { Value of } \\
\text { imple- } \\
\text { ments and } \\
\text { machinery }\end{array}$} \\
\hline & & & Total & Land alone & Buildings & \\
\hline & \multicolumn{6}{|c|}{ TENNESSEE-continued } \\
\hline $\begin{array}{l}\text { Dickson } \\
\text { Dyer } \\
\text { Fayette } \\
\text { Franklin } \\
\text { Glbson....... }\end{array}$ & $\begin{array}{r}202 \\
314 \\
4,432 \\
160 \\
1,088\end{array}$ & $\begin{array}{r}7,703 \\
9,410 \\
209,739 \\
5,901 \\
34,828\end{array}$ & $\begin{array}{r}\$ 141,260 \\
583,600 \\
5,325,794 \\
238,390 \\
1,899,111\end{array}$ & $\begin{array}{r}\$ 92,985 \\
479,370 \\
4,016,274 \\
161,925 \\
1,438,676\end{array}$ & $\begin{array}{r}\$ 48,275 \\
104,230 \\
1,309,520 \\
76,465 \\
460,435\end{array}$ & $\begin{array}{r}\$ 7,733 \\
34,960 \\
401,615 \\
13,035 \\
120,042\end{array}$ \\
\hline $\begin{array}{l}\text { Giles } \\
\text { Grainger } \\
\text { Greene } \\
\text { Hamblen } \\
\text { Hamilton }\end{array}$ & $\begin{array}{r}1,061 \\
30 \\
65 \\
75 \\
138\end{array}$ & $\begin{array}{r}43,690 \\
1,114 \\
1,599 \\
2,384 \\
5,837\end{array}$ & $\begin{array}{r}1,514,233 \\
25,730 \\
110,126 \\
150,220 \\
381,580\end{array}$ & $\begin{array}{r}1,095,248 \\
18,445 \\
81,076 \\
90,595 \\
282,280\end{array}$ & $\begin{array}{r}418,985 \\
7,285 \\
29,050 \\
59,625 \\
99,300\end{array}$ & $\begin{array}{r}77,184 \\
1,050 \\
7,105 \\
9,320 \\
11,819\end{array}$ \\
\hline $\begin{array}{l}\text { Hancock. } \\
\text { Hardeman } \\
\text { Hardin } \\
\text { Hawkins } \\
\text { Haywood }\end{array}$ & $\begin{array}{r}27 \\
1,446 \\
185 \\
85 \\
3,512\end{array}$ & $\begin{array}{r}843 \\
86,636 \\
7,757 \\
2,732 \\
127,037\end{array}$ & $\begin{array}{r}22,260 \\
1,502,521 \\
179,040 \\
106,325 \\
4,938,844\end{array}$ & $\begin{array}{r}16,810 \\
1,059,275 \\
134,390 \\
72,815 \\
3,456,154\end{array}$ & $\begin{array}{r}5,450 \\
443,246 \\
44,650 \\
33,510 \\
1,482,690\end{array}$ & $\begin{array}{r}1,010 \\
112,815 \\
12,325 \\
5,989 \\
337,514\end{array}$ \\
\hline $\begin{array}{l}\text { Henderson } \\
\text { Henry } \\
\text { Hickman } \\
\text { Houston } \\
\text { Humphreys. }\end{array}$ & $\begin{array}{r}232 \\
418 \\
57 \\
46 \\
27\end{array}$ & $\begin{array}{r}14,543 \\
24,052 \\
3,228 \\
2,081 \\
1,622\end{array}$ & $\begin{array}{r}242,310 \\
548,693 \\
72,855 \\
32,805 \\
51,290\end{array}$ & $\begin{array}{r}162,035 \\
387,853 \\
59,675 \\
21,955 \\
44,800\end{array}$ & $\begin{array}{r}80,275 \\
160,840 \\
13,180 \\
10,850 \\
6,490\end{array}$ & $\begin{array}{r}19,562 \\
29,522 \\
4,458 \\
914 \\
2,195\end{array}$ \\
\hline $\begin{array}{l}\text { Jackson } \\
\text { Jefferson } \\
\text { Johnson } \\
\text { Knox } \\
\text { Lake }\end{array}$ & $\begin{array}{r}9 \\
70 \\
20 \\
105 \\
276\end{array}$ & $\begin{array}{r}323 \\
2,946 \\
408 \\
3,882 \\
8,500\end{array}$ & $\begin{array}{r}13,600 \\
180,575 \\
39,925 \\
334,440 \\
737,815\end{array}$ & $\begin{array}{r}10,500 \\
128,325 \\
14,475 \\
216,190 \\
646,473\end{array}$ & $\begin{array}{r}3,100 \\
52,250 \\
25,450 \\
118,250 \\
91,342\end{array}$ & $\begin{array}{r}335 \\
7,475 \\
450 \\
8,933 \\
23,438\end{array}$ \\
\hline $\begin{array}{l}\text { Lauderdale. } \\
\text { Lawrence. } \\
\text { Lewis } \\
\text { Lincoln } \\
\text { Loudon }\end{array}$ & $\begin{array}{r}1,618 \\
53 \\
9 \\
476 \\
54\end{array}$ & $\begin{array}{r}47,316 \\
2,375 \\
471 \\
19,943 \\
2,595\end{array}$ & $\begin{array}{r}2,568,265 \\
48,900 \\
6,700 \\
821,505 \\
75,070\end{array}$ & $\begin{array}{r}2,025,452 \\
32,065 \\
5,370 \\
590,685 \\
55,445\end{array}$ & $\begin{array}{r}542,813 \\
16,835 \\
1,330 \\
230,820 \\
19,625\end{array}$ & $\begin{array}{r}115,527 \\
2,542 \\
490 \\
41,113 \\
2,470\end{array}$ \\
\hline $\begin{array}{l}\text { McMinn } \\
\text { McNairy } \\
\text { Macon } \\
\text { Madison } \\
\text { Marion }\end{array}$ & $\begin{array}{r}109 \\
184 \\
53 \\
1,997 \\
35\end{array}$ & $\begin{array}{r}4,602 \\
11,244 \\
1,867 \\
84,264 \\
1,342\end{array}$ & $\begin{array}{r}158,380 \\
214,885 \\
40,900 \\
3,464,388 \\
43,410\end{array}$ & $\begin{array}{r}97,085 \\
164,150 \\
26,955 \\
2,757,063 \\
30,075\end{array}$ & $\begin{array}{r}61,295 \\
60,735 \\
13,945 \\
707,325 \\
13,335\end{array}$ & $\begin{array}{r}10,234 \\
12,905 \\
2,542 \\
153,909 \\
2,550\end{array}$ \\
\hline $\begin{array}{l}\text { Marshali. } \\
\text { Maury } \\
\text { Meigs } \\
\text { Monroe... } \\
\text { Montgomery. }\end{array}$ & $\begin{array}{r}199 \\
602 \\
47 \\
67 \\
1,022\end{array}$ & $\begin{array}{r}9,750 \\
23,337 \\
4,573 \\
2,165 \\
39,844\end{array}$ & $\begin{array}{r}332,689 \\
937,170 \\
79,385 \\
87,505 \\
1,303,945\end{array}$ & $\begin{array}{r}232,859 \\
665,380 \\
66,545 \\
58,445 \\
814,030\end{array}$ & $\begin{array}{r}99,830 \\
271,790 \\
12,840 \\
29,060 \\
489,915\end{array}$ & $\begin{array}{r}16,929 \\
47,742 \\
4,538 \\
7,488 \\
50,364\end{array}$ \\
\hline $\begin{array}{l}\text { Moore } \\
\text { Obion } \\
\text { Overton } \\
\text { Perry... } \\
\text { Polk }\end{array}$ & $\begin{array}{r}60 \\
118 \\
15 \\
25 \\
16\end{array}$ & $\begin{array}{r}2,272 \\
5,542 \\
448 \\
1,374 \\
940\end{array}$ & $\begin{array}{r}71,880 \\
370,330 \\
9,875 \\
38,150 \\
28,800\end{array}$ & $\begin{array}{r}55,195 \\
283,805 \\
7,105 \\
27,800 \\
20,725\end{array}$ & $\begin{array}{r}16,685 \\
86,525 \\
2,770 \\
10,350 \\
8,075\end{array}$ & $\begin{array}{r}4,365 \\
15,690 \\
395 \\
3,193 \\
755\end{array}$ \\
\hline $\begin{array}{l}\text { Putnam } \\
\text { Rhes } \\
\text { Roane } \\
\text { Robertson } \\
\text { Rutherford }\end{array}$ & $\begin{array}{r}59 \\
27 \\
25 \\
789 \\
979\end{array}$ & $\begin{array}{r}1,908 \\
1,034 \\
1,259 \\
23,839 \\
34,376\end{array}$ & $\begin{array}{r}87,575 \\
40,645 \\
21,225 \\
1,209,596 \\
1,356,430\end{array}$ & $\begin{array}{r}61,970 \\
32,995 \\
11,625 \\
869,966 \\
1,048,977\end{array}$ & $\begin{array}{r}25,605 \\
7,650 \\
9,600 \\
339,630 \\
307,453\end{array}$ & $\begin{array}{r}3,741 \\
1,800 \\
1,113 \\
57,180 \\
76,335\end{array}$ \\
\hline $\begin{array}{l}\text { Sevier. } \\
\text { Shelby } \\
\text { Smith } \\
\text { Stewart } \\
\text { Sullivan }\end{array}$ & $\begin{array}{r}15 \\
5,548 \\
79 \\
65 \\
9\end{array}$ & $\begin{array}{r}688 \\
157,088 \\
2,708 \\
3,001 \\
131\end{array}$ & $\begin{array}{r}49,750 \\
12,657,124 \\
97,350 \\
64,696 \\
15,500\end{array}$ & $\begin{array}{r}37,795 \\
10,305,371 \\
69,035 \\
45,491 \\
9,740\end{array}$ & $\begin{array}{r}11,955 \\
2,351,753 \\
28,315 \\
19,205 \\
5,760\end{array}$ & $\begin{array}{r}2,805 \\
485,572 \\
3,365 \\
2,320 \\
1,300\end{array}$ \\
\hline $\begin{array}{l}\text { Sumner } \\
\text { Tipton } \\
\text { Trousdalo } \\
\text { Van Buren } \\
\text { Warren } \\
\text { Washington }\end{array}$ & $\begin{array}{r}397 \\
2,144 \\
138 \\
7 \\
100 \\
22\end{array}$ & $\begin{array}{r}13,084 \\
70,017 \\
4,539 \\
627 \\
5,464 \\
610\end{array}$ & $\begin{array}{r}644,215 \\
3,265,051 \\
201,850 \\
14,000 \\
122,695 \\
44,485\end{array}$ & $\begin{array}{r}437,730 \\
2,521,680 \\
140,985 \\
9,300 \\
85,190 \\
31,795\end{array}$ & $\begin{array}{r}206,485 \\
743,371 \\
60,865 \\
4,700 \\
37,505 \\
12,690\end{array}$ & $\begin{array}{r}28,537 \\
213,973 \\
9,030 \\
580 \\
6,211 \\
2,385\end{array}$ \\
\hline
\end{tabular}


Table 38. - Farms Operated by Negroes-Number, Acreage, and Value of Specified Classes of Farm Property, by States and Counties, 1930 Continued

\begin{tabular}{|c|c|c|c|c|c|c|}
\hline \multirow{2}{*}{ STATE AND COUNTY } & \multirow{2}{*}{$\begin{array}{l}\text { Number } \\
\text { of farms }\end{array}$} & \multirow{2}{*}{$\begin{array}{l}\text { Land in } \\
\text { farms } \\
\text { (acres) }\end{array}$} & \multicolumn{3}{|c|}{ VALUE OF ILAND AND BOILDINGS } & \multirow{2}{*}{$\begin{array}{l}\text { Value of } \\
\text { lmple- } \\
\text { ments and } \\
\text { machinery }\end{array}$} \\
\hline & & & Total & Land alone & Buildings & \\
\hline \multirow{3}{*}{$\begin{array}{l}\text { Wayne } \\
\text { Weakley } \\
\text { White } \\
\text { Williamson } \\
\text { Wilson } \\
\text { Other counties....... }\end{array}$} & \multicolumn{5}{|c|}{ TENNESSEE-continued } & \\
\hline & $\begin{array}{r}21 \\
203 \\
50 \\
394 \\
498 \\
8\end{array}$ & $\begin{array}{r}795 \\
7,184 \\
2,729 \\
19,491 \\
16,977 \\
350\end{array}$ & $\begin{array}{r}\$ 14,475 \\
277,800 \\
91,995 \\
775,715 \\
665,973 \\
7,600\end{array}$ & $\begin{array}{r}\$ 11,000 \\
192,815 \\
62,345 \\
582,935 \\
476,178 \\
4,700\end{array}$ & $\begin{array}{r}\$ 3,475 \\
84,985 \\
29,650 \\
192,780 \\
189,795 \\
2,900\end{array}$ & $\begin{array}{r}\$ 1,055 \\
11,896 \\
4,901 \\
34,049 \\
28,785 \\
430\end{array}$ \\
\hline & \multicolumn{6}{|c|}{ TEXAS } \\
\hline Total $\ldots \ldots$ & 85,840 & $4,429,671$ & $8179,391,988$ & $8148,803,812$ & $\$ 30,788,176$ & $87,731,019$ \\
\hline $\begin{array}{l}\text { Anderson } \\
\text { Angelina } \\
\text { Atascosa } \\
\text { Austin } \\
\text { Bastrop......... }\end{array}$ & $\begin{array}{r}1,765 \\
160 \\
20 \\
847 \\
1,139\end{array}$ & $\begin{array}{r}97,801 \\
6,476 \\
9,619 \\
36,815 \\
76,477\end{array}$ & $\begin{array}{r}2,227,388 \\
225,650 \\
169,310 \\
2,067,995 \\
2,725,734\end{array}$ & $\begin{array}{r}1,605,275 \\
167,495 \\
160,190 \\
1,673,035 \\
2,312,818\end{array}$ & $\begin{array}{r}622,113 \\
58,155 \\
9,120 \\
394,960 \\
412,916\end{array}$ & $\begin{array}{r}149,119 \\
11,595 \\
2,645 \\
96,052 \\
112,575\end{array}$ \\
\hline $\begin{array}{l}\text { Bee } \\
\text { Bell } \\
\text { Bexar, } \\
\text { Blanco } \\
\text { Bosque }\end{array}$ & $\begin{array}{r}26 \\
403 \\
94 \\
26 \\
47\end{array}$ & $\begin{array}{r}2,456 \\
18,284 \\
5,942 \\
6,004 \\
4,566\end{array}$ & $\begin{array}{r}120,165 \\
1,695,115 \\
496,920 \\
64,850 \\
177,925\end{array}$ & $\begin{array}{r}106,140 \\
1,484,710 \\
424,461 \\
52,499 \\
151,560\end{array}$ & $\begin{array}{r}14,025 \\
210,405 \\
72,459 \\
12,351 \\
26,365\end{array}$ & $\begin{array}{r}3,154 \\
55,521 \\
9,865 \\
1,569 \\
8,685\end{array}$ \\
\hline $\begin{array}{l}\text { Bowie } \\
\text { Brazoria } \\
\text { Brazos...... } \\
\text { Briscoe } \\
\text { Burleson }\end{array}$ & $\begin{array}{r}1,962 \\
981 \\
1,237 \\
5 \\
1,313\end{array}$ & $\begin{array}{r}72,671 \\
38,800 \\
65,486 \\
251 \\
69,684\end{array}$ & $\begin{array}{r}3,267,850 \\
2,006,959 \\
2,428,173 \\
18,225 \\
3,432,422\end{array}$ & $\begin{array}{r}2,616,636 \\
1,611,693 \\
1,962,651 \\
16,575 \\
2,992,889\end{array}$ & $\begin{array}{r}651,214 \\
395,266 \\
465,522 \\
1,650 \\
439,533\end{array}$ & $\begin{array}{r}137,271 \\
103,890 \\
145,072 \\
1,250 \\
123,794\end{array}$ \\
\hline $\begin{array}{l}\text { Burnet } \\
\text { Caldwell } \\
\text { Calhoun } \\
\text { Cameron. } \\
\text { Camp.... }\end{array}$ & $\begin{array}{r}7 \\
546 \\
24 \\
14 \\
618\end{array}$ & $\begin{array}{r}593 \\
34,796 \\
1,755 \\
530 \\
29,800\end{array}$ & $\begin{array}{r}23,250 \\
1,767,000 \\
112,770 \\
131,525 \\
670,155\end{array}$ & $\begin{array}{r}17,050 \\
1,524,175 \\
102,770 \\
122,640 \\
474,173\end{array}$ & $\begin{array}{r}6,200 \\
242,825 \\
10,000 \\
8,885 \\
195,982\end{array}$ & $\begin{array}{r}1,880 \\
81,218 \\
6,200 \\
5,515 \\
35,108\end{array}$ \\
\hline $\begin{array}{l}\text { Cass. } \\
\text { Chambers } \\
\text { Cherokee. } \\
\text { Childress }\end{array}$ & $\begin{array}{r}2,073 \\
155 \\
1,862 \\
17 \\
21\end{array}$ & $\begin{array}{r}109,161 \\
28,878 \\
90,658 \\
1,676 \\
771\end{array}$ & $\begin{array}{r}2,219,951 \\
519,109 \\
2,690,724 \\
121,560 \\
68,260\end{array}$ & $\begin{array}{r}1,597,274 \\
456,884 \\
2,044,268 \\
99,960 \\
60,560\end{array}$ & $\begin{array}{r}622,677 \\
62,225 \\
646,456 \\
21,600 \\
7,700\end{array}$ & $\begin{array}{r}132,666 \\
19,030 \\
181,160 \\
3,455 \\
5,950\end{array}$ \\
\hline $\begin{array}{l}\text { Coleman } \\
\text { Collin } \\
\text { Collingsworth } \\
\text { Colorado } \\
\text { Comal. }\end{array}$ & $\begin{array}{r}16 \\
310 \\
59 \\
776 \\
9\end{array}$ & $\begin{array}{r}842 \\
12,755 \\
3,592 \\
37,918 \\
1,111\end{array}$ & $\begin{array}{r}68,180 \\
1,126,610 \\
208,700 \\
1,644,627 \\
43,500\end{array}$ & $\begin{array}{r}65,355 \\
1,016,775 \\
198,255 \\
1,367,697 \\
38,150\end{array}$ & $\begin{array}{r}2,825 \\
109,835 \\
10,445 \\
276,930 \\
5,350\end{array}$ & $\begin{array}{r}2,355 \\
28,945 \\
5,460 \\
91,556 \\
2,150\end{array}$ \\
\hline $\begin{array}{l}\text { Concho. } \\
\text { Cooke } \\
\text { Coryell } \\
\text { Cottle } \\
\text { Crosby }\end{array}$ & $\begin{array}{l}15 \\
65 \\
15 \\
12 \\
31\end{array}$ & $\begin{array}{l}1,024 \\
3,322 \\
1,382 \\
1,113 \\
2,253\end{array}$ & $\begin{array}{r}61,040 \\
156,472 \\
89,455 \\
54,360 \\
118,625\end{array}$ & $\begin{array}{r}55,490 \\
132,038 \\
82,555 \\
46,260 \\
111,050\end{array}$ & $\begin{array}{r}5,550 \\
24,434 \\
6,900 \\
8,100 \\
7,575\end{array}$ & $\begin{array}{l}3,225 \\
5,931 \\
2,700 \\
3,500 \\
2,225\end{array}$ \\
\hline $\begin{array}{l}\text { Dallas. } \\
\text { Dawson } \\
\text { Delta. } \\
\text { Denton } \\
\text { De Witt }\end{array}$ & $\begin{array}{r}657 \\
30 \\
159 \\
186 \\
397\end{array}$ & $\begin{array}{r}27,118 \\
1,557 \\
4,674 \\
12,597 \\
35,888\end{array}$ & $\begin{array}{r}3,504,665 \\
82,600 \\
359,710 \\
583,635 \\
1,647,105\end{array}$ & $\begin{array}{r}3,179,350 \\
73,470 \\
316,435 \\
503,685 \\
1,355,138\end{array}$ & $\begin{array}{r}325,315 \\
9,130 \\
43,275 \\
79,950 \\
291,967\end{array}$ & $\begin{array}{r}61,832 \\
2,065 \\
12,785 \\
15,019 \\
77,701\end{array}$ \\
\hline $\begin{array}{l}\text { Dickens } \\
\text { Donley } \\
\text { Ellis } \\
\text { El Paso } \\
\text { Erath }\end{array}$ & $\begin{array}{r}27 \\
7 \\
1,174 \\
9 \\
12\end{array}$ & $\begin{array}{r}2,814 \\
98 \\
46,853 \\
268 \\
892\end{array}$ & $\begin{array}{r}112,270 \\
6,450 \\
4,560,068 \\
69,650 \\
28,750\end{array}$ & $\begin{array}{r}106,370 \\
6,100 \\
4,106,718 \\
56,350 \\
20,425\end{array}$ & $\begin{array}{r}5,900 \\
350 \\
453,350 \\
13,300 \\
8,325\end{array}$ & $\begin{array}{r}2,550 \\
500 \\
108,550 \\
4,825 \\
3,365\end{array}$ \\
\hline $\begin{array}{l}\text { Falls } \\
\text { Fannin } \\
\text { Fayette } \\
\text { Fisher } \\
\text { Floyd }\end{array}$ & $\begin{array}{r}1,885 \\
441 \\
1,045 \\
48 \\
8\end{array}$ & $\begin{array}{r}82,273 \\
23,101 \\
59,300 \\
4,350 \\
385\end{array}$ & $\begin{array}{r}5,390,450 \\
1,013,626 \\
2,612,361 \\
226,915 \\
15,400\end{array}$ & $\begin{array}{r}4,727,325 \\
844,026 \\
2,178,206 \\
207,090 \\
13,800\end{array}$ & $\begin{array}{r}663,125 \\
169,600 \\
434,155 \\
19,825 \\
1,600\end{array}$ & $\begin{array}{r}175,270 \\
39,400 \\
108,887 \\
9,075 \\
1,550\end{array}$ \\
\hline
\end{tabular}


Table 38.-Farms Operated by Negroes-Number, Acreage, and Value of Specified Classes of Farm Property, by States and Counties, 1930Continued

\begin{tabular}{|c|c|c|c|c|c|c|}
\hline \multirow{2}{*}{ STATE AND COUNTY } & \multirow{2}{*}{$\begin{array}{l}\text { Number } \\
\text { of farms }\end{array}$} & \multirow{2}{*}{$\begin{array}{l}\text { Land in } \\
\text { farms } \\
\text { (acres) }\end{array}$} & \multicolumn{3}{|c|}{ VALUE OF LAND AND BUILDINGS } & \multirow{2}{*}{$\begin{array}{l}\text { Value of } \\
\text { imple- } \\
\text { ments and } \\
\text { machinery }\end{array}$} \\
\hline & & & Total & Land alone & Buildings & \\
\hline & \multicolumn{6}{|c|}{ TEXAS-continued } \\
\hline $\begin{array}{l}\text { Fort Bend } \\
\text { Franklin } \\
\text { Freestone } \\
\text { Frio } \\
\text { Galveston }\end{array}$ & $\begin{array}{r}1,824 \\
84 \\
1,689 \\
10 \\
60\end{array}$ & $\begin{array}{r}86,629 \\
4,109 \\
109,501 \\
2,430 \\
1,199\end{array}$ & $\begin{array}{r}\$ 6,059,733 \\
113,550 \\
2,853,628 \\
59,935 \\
159,100\end{array}$ & $\begin{array}{r}\$ 5,225,705 \\
93,505 \\
2,256,448 \\
49,435 \\
114,025\end{array}$ & $\begin{array}{r}\$ 834,028 \\
20,045 \\
597,180 \\
10,500 \\
45,075\end{array}$ & $\begin{array}{r}\$ 239,252 \\
4,466 \\
120,310 \\
2,250 \\
7,452\end{array}$ \\
\hline $\begin{array}{l}\text { Garza } \\
\text { Gillespie. } \\
\text { Goliad } \\
\text { Gonzales. } \\
\text { Grayson }\end{array}$ & $\begin{array}{r}6 \\
8 \\
103 \\
1,065 \\
251\end{array}$ & $\begin{array}{r}123 \\
463 \\
6,367 \\
68,523 \\
11,797\end{array}$ & $\begin{array}{r}3,880 \\
23,000 \\
233,865 \\
2,460,289 \\
624,300\end{array}$ & $\begin{array}{r}3,580 \\
19,450 \\
171,780 \\
2,105,136 \\
518,215\end{array}$ & $\begin{array}{r}300 \\
3,550 \\
62,085 \\
355,153 \\
106,085\end{array}$ & $\begin{array}{r}125 \\
1,540 \\
18,578 \\
94,828 \\
16,903\end{array}$ \\
\hline $\begin{array}{l}\text { Gregg } \\
\text { Grimes } \\
\text { Guadalupe. } \\
\text { Hall } \\
\text { Hardeman }\end{array}$ & $\begin{array}{r}1,220 \\
1,471 \\
609 \\
86 \\
35\end{array}$ & $\begin{array}{r}62,996 \\
73,659 \\
53,036 \\
2,562 \\
2,787\end{array}$ & $\begin{array}{r}1,800,293 \\
2,461,360 \\
2,546,540 \\
183,110 \\
150,175\end{array}$ & $\begin{array}{r}1,388,198 \\
1,876,458 \\
2,252,106 \\
164,850 \\
135,975\end{array}$ & $\begin{array}{r}412,095 \\
584,902 \\
294,434 \\
18,260 \\
14,200\end{array}$ & $\begin{array}{r}97,136 \\
124,938 \\
73,118 \\
7,908 \\
5,655\end{array}$ \\
\hline $\begin{array}{l}\text { Hardin } \\
\text { Harris } \\
\text { Harrison..... } \\
\text { Haskell } \\
\text { Hays }\end{array}$ & $\begin{array}{r}36 \\
651 \\
4,990 \\
23 \\
69\end{array}$ & $\begin{array}{r}762 \\
32,323 \\
220,764 \\
2,981 \\
3,874\end{array}$ & $\begin{array}{r}49,630 \\
5,405,136 \\
5,873,158 \\
130,280 \\
263,895\end{array}$ & $\begin{array}{r}35,990 \\
4,945,226 \\
4,183,117 \\
118,380 \\
213,470\end{array}$ & $\begin{array}{r}13,640 \\
459,910 \\
1,690,041 \\
11,900 \\
50,425\end{array}$ & $\begin{array}{r}2,011 \\
80,873 \\
305,470 \\
6,125 \\
11,203\end{array}$ \\
\hline $\begin{array}{l}\text { Henderson. } \\
\text { Hidalgo... } \\
\text { Hill } \\
\text { Hockley } \\
\text { Hood }\end{array}$ & $\begin{array}{r}850 \\
7 \\
575 \\
6 \\
8\end{array}$ & $\begin{array}{r}47,083 \\
520 \\
23,075 \\
272 \\
405\end{array}$ & $\begin{array}{r}1,311,540 \\
109,300 \\
1,687,175 \\
13,350 \\
14,100\end{array}$ & $\begin{array}{r}1,023,430 \\
107,025 \\
1,484,065 \\
11,950 \\
11,950\end{array}$ & $\begin{array}{r}288,110 \\
2,275 \\
203,110 \\
1,400 \\
2,150\end{array}$ & $\begin{array}{r}58,220 \\
1,500 \\
58,184 \\
250 \\
260\end{array}$ \\
\hline $\begin{array}{l}\text { Hopkins. } \\
\text { Houston. } \\
\text { Hunt } \\
\text { Jackson. } \\
\text { Jasper. }\end{array}$ & $\begin{array}{r}323 \\
2,627 \\
426 \\
277 \\
397\end{array}$ & $\begin{array}{r}19,171 \\
114,704 \\
17,578 \\
22,455 \\
15,424\end{array}$ & $\begin{array}{r}544,871 \\
2,924,311 \\
1,050,005 \\
740,375 \\
400,620\end{array}$ & $\begin{array}{r}413,381 \\
2,301,281 \\
907,031 \\
596,647 \\
281,050\end{array}$ & $\begin{array}{l}131,490 \\
623,030 \\
142,974 \\
143,728 \\
119,570\end{array}$ & $\begin{array}{r}22,715 \\
220,059 \\
37,140 \\
39,507 \\
23,159\end{array}$ \\
\hline $\begin{array}{l}\text { Jefferson } \\
\text { Jim Wells } \\
\text { Johnson } \\
\text { Jones. } \\
\text { Karnes }\end{array}$ & $\begin{array}{r}103 \\
9 \\
87 \\
20 \\
95\end{array}$ & $\begin{array}{r}6,718 \\
3,936 \\
4,741 \\
1,894 \\
10,532\end{array}$ & $\begin{array}{l}534,670 \\
140,645 \\
347,485 \\
124,050 \\
446,795\end{array}$ & $\begin{array}{l}455,950 \\
131,945 \\
308,885 \\
116,660 \\
393,680\end{array}$ & $\begin{array}{r}78,720 \\
8,700 \\
38,600 \\
7,390 \\
53,115\end{array}$ & $\begin{array}{r}15,500 \\
1,555 \\
9,920 \\
3,165 \\
21,035\end{array}$ \\
\hline $\begin{array}{l}\text { Kaufman. } \\
\text { Kent..... } \\
\text { Kleberg.... } \\
\text { Knox } \\
\text { Lamar....... }\end{array}$ & $\begin{array}{r}1,403 \\
6 \\
5 \\
11 \\
1,098\end{array}$ & $\begin{array}{r}71,028 \\
585 \\
307 \\
463 \\
49,982\end{array}$ & $\begin{array}{r}3,927,205 \\
20,150 \\
18,265 \\
27,060 \\
2,653,045\end{array}$ & $\begin{array}{r}3,373,865 \\
19,150 \\
16,090 \\
25,410 \\
2,249,201\end{array}$ & $\begin{array}{r}553,340 \\
1,000 \\
2,175 \\
1,650 \\
403,844\end{array}$ & $\begin{array}{r}97,413 \\
675 \\
835 \\
1,350 \\
80,484\end{array}$ \\
\hline $\begin{array}{l}\text { Lamb_... } \\
\text { Lampasas } \\
\text { Lavaca... } \\
\text { Lee... }\end{array}$ & $\begin{array}{r}32 \\
6 \\
439 \\
660 \\
2,028\end{array}$ & $\begin{array}{r}1,539 \\
737 \\
30,742 \\
62,129 \\
103,154\end{array}$ & $\begin{array}{r}85,030 \\
25,600 \\
1,186,427 \\
1,356,455 \\
2,215,561\end{array}$ & $\begin{array}{r}79,655 \\
20,500 \\
972,767 \\
1,141,713 \\
1,641,438\end{array}$ & $\begin{array}{r}5,375 \\
5,100 \\
213,660 \\
214,742 \\
574,123\end{array}$ & $\begin{array}{r}4,625 \\
1,150 \\
34,017 \\
56,158 \\
151,366\end{array}$ \\
\hline $\begin{array}{l}\text { Liberty } \\
\text { Limestone.... } \\
\text { Lubbock } \\
\text { Lynn } \\
\text { McCulloch }\end{array}$ & $\begin{array}{r}506 \\
1,740 \\
35 \\
26 \\
14\end{array}$ & $\begin{array}{r}19,443 \\
80,899 \\
2,565 \\
1,606 \\
1,445\end{array}$ & $\begin{array}{r}745,325 \\
4,813,143 \\
277,390 \\
71,540 \\
62,100\end{array}$ & $\begin{array}{r}570,573 \\
4,142,066 \\
253,395 \\
66,115 \\
56,750\end{array}$ & $\begin{array}{r}174,752 \\
671,077 \\
23,995 \\
5,425 \\
5,350\end{array}$ & $\begin{array}{r}57,352 \\
185,707 \\
6,630 \\
2,670 \\
3,020\end{array}$ \\
\hline $\begin{array}{l}\text { McLennan } \\
\text { Madison } \\
\text { Marion } \\
\text { Matagorda. } \\
\text { Medina }\end{array}$ & $\begin{array}{r}1,422 \\
747 \\
1,085 \\
604 \\
22\end{array}$ & $\begin{array}{r}66,882 \\
46,458 \\
60,221 \\
25,827 \\
1,878\end{array}$ & $\begin{array}{r}5,361,406 \\
968,062 \\
1,115,469 \\
980,874 \\
63,950\end{array}$ & $\begin{array}{r}4,787,551 \\
785,215 \\
741,984 \\
780,235 \\
53,350\end{array}$ & $\begin{array}{r}573,855 \\
182,847 \\
373,485 \\
200,639 \\
10,600\end{array}$ & $\begin{array}{r}175,648 \\
52,144 \\
73,313 \\
69,612 \\
2,080\end{array}$ \\
\hline $\begin{array}{l}\text { Milam } \\
\text { Mitcheil } \\
\text { Montgomery. } \\
\text { Morris } \\
\text { Motley }\end{array}$ & $\begin{array}{r}1,307 \\
52 \\
684 \\
633 \\
18\end{array}$ & $\begin{array}{r}71,863 \\
6,738 \\
31,164 \\
34,305 \\
1,048\end{array}$ & $\begin{array}{r}3,669,120 \\
263,230 \\
684,008 \\
721,957 \\
52,660\end{array}$ & $\begin{array}{r}3,131,378 \\
236,080 \\
481,025 \\
551,614 \\
49,060\end{array}$ & $\begin{array}{r}537,742 \\
27,150 \\
202,983 \\
170,343 \\
3,600\end{array}$ & $\begin{array}{r}130,933 \\
7,695 \\
49,142 \\
32,352 \\
1,940\end{array}$ \\
\hline
\end{tabular}


Table 38.-Farms Operated by Negroes-Number, Acreage, and Value of Specified Classes of Farm Property, by States and Counties, 1930 Continued

\begin{tabular}{|c|c|c|c|c|c|c|}
\hline \multirow{2}{*}{ STATE AND COUNTY } & \multirow{2}{*}{$\begin{array}{l}\text { Number } \\
\text { of farms }\end{array}$} & \multirow{2}{*}{$\begin{array}{l}\text { Land in } \\
\text { farms } \\
\text { (acres) }\end{array}$} & \multicolumn{3}{|c|}{ VALUE OF IAND AND BUILDINGS } & \multirow{2}{*}{$\begin{array}{l}\text { Value of } \\
\text { imple- } \\
\text { ments and } \\
\text { machinery }\end{array}$} \\
\hline & & & Total & Land alone & Buildings & \\
\hline & \multicolumn{6}{|c|}{ TEXAS-continued } \\
\hline $\begin{array}{l}\text { Nacogdoches } \\
\text { Navarro } \\
\text { Newton } \\
\text { Nolan } \\
\text { Nueces... }\end{array}$ & $\begin{array}{r}994 \\
1,661 \\
467 \\
8 \\
16\end{array}$ & $\begin{array}{r}50,474 \\
85,144 \\
19,164 \\
939 \\
1,445\end{array}$ & $\begin{array}{r}\$ 1,339,008 \\
5,725,335 \\
434,408 \\
38,910 \\
130,675\end{array}$ & $\begin{array}{r}\$ 1,017,078 \\
5,063,602 \\
307,427 \\
33,360 \\
119,750\end{array}$ & $\begin{array}{r}\$ 321,930 \\
661,733 \\
126,981 \\
5,550 \\
10,925\end{array}$ & $\begin{array}{r}\$ 87,421 \\
212,339 \\
25,914 \\
1,400 \\
8,300\end{array}$ \\
\hline $\begin{array}{l}\text { Orange } \\
\text { Panola } \\
\text { Parker } \\
\text { Polk } \\
\text { Rains }\end{array}$ & $\begin{array}{r}8 \\
2,117 \\
10 \\
782 \\
153\end{array}$ & $\begin{array}{r}325 \\
98,215 \\
1,031 \\
29,983 \\
6,382\end{array}$ & $\begin{array}{r}14,900 \\
2,469,300 \\
35,775 \\
1,067,818 \\
175,320\end{array}$ & $\begin{array}{r}12,050 \\
1,883,011 \\
28,075 \\
826,374 \\
126,770\end{array}$ & $\begin{array}{r}2,850 \\
586,289 \\
7,700 \\
241,474 \\
48,550\end{array}$ & $\begin{array}{r}878 \\
192,277 \\
1,520 \\
57,985 \\
15,705\end{array}$ \\
\hline $\begin{array}{l}\text { Red River.... } \\
\text { Refugio } \\
\text { Robertson..... } \\
\text { Rockwall.... } \\
\text { Runnels..... }\end{array}$ & $\begin{array}{r}1,297 \\
35 \\
1,869 \\
250 \\
21\end{array}$ & $\begin{array}{r}58,040 \\
1,900 \\
95,266 \\
7,356 \\
2,956\end{array}$ & $\begin{array}{r}2,077,627 \\
79,474 \\
4,365,407 \\
612,351 \\
178,950\end{array}$ & $\begin{array}{r}1,698,103 \\
66,349 \\
3,670,594 \\
549,786 \\
164,250\end{array}$ & $\begin{array}{r}379,524 \\
13,125 \\
694,813 \\
62,565 \\
14,700\end{array}$ & $\begin{array}{r}71,081 \\
3,827 \\
137,804 \\
24,590 \\
2,160\end{array}$ \\
\hline $\begin{array}{l}\text { Rusk } \\
\text { Sabine } \\
\text { San Augustine } \\
\text { San Jacinto } \\
\text { San Patricio. }\end{array}$ & $\begin{array}{r}2,784 \\
288 \\
508 \\
962 \\
18\end{array}$ & $\begin{array}{r}157,454 \\
13,150 \\
27,400 \\
35,984 \\
720\end{array}$ & $\begin{array}{r}3,856,117 \\
380,980 \\
695,036 \\
946,680 \\
66,975\end{array}$ & $\begin{array}{r}2,942,914 \\
276,320 \\
554,896 \\
726,046 \\
59,600\end{array}$ & $\begin{array}{r}913,203 \\
104,660 \\
140,140 \\
220,634 \\
7,375\end{array}$ & $\begin{array}{r}292,783 \\
25,695 \\
30,920 \\
51,421 \\
3,310\end{array}$ \\
\hline $\begin{array}{l}\text { Shelby } \\
\text { Smith............... } \\
\text { Stonewall.... } \\
\text { Tarrant...... } \\
\text { Taylor...... }\end{array}$ & $\begin{array}{r}1,196 \\
3,120 \\
18 \\
106 \\
15\end{array}$ & $\begin{array}{r}47,644 \\
166,337 \\
1,786 \\
5,191 \\
1,335\end{array}$ & $\begin{array}{r}1,329,163 \\
4,834,466 \\
76,550 \\
411,095 \\
66,400\end{array}$ & $\begin{array}{r}988,866 \\
3,757,056 \\
68,025 \\
366,690 \\
60,550\end{array}$ & $\begin{array}{r}340,297 \\
1,077,410 \\
8,525 \\
44,405 \\
5,850\end{array}$ & $\begin{array}{r}61,895 \\
250,007 \\
1,785 \\
8,075 \\
2,175\end{array}$ \\
\hline $\begin{array}{l}\text { Terry } \\
\text { Titus } \\
\text { Tom Green... } \\
\text { Travis....... } \\
\text { Trinity }\end{array}$ & $\begin{array}{r}10 \\
315 \\
8 \\
820 \\
308\end{array}$ & $\begin{array}{r}381 \\
15,701 \\
525 \\
46,814 \\
11,763\end{array}$ & $\begin{array}{r}12,990 \\
435,313 \\
33,375 \\
3,098,557 \\
312,790\end{array}$ & $\begin{array}{r}12,490 \\
337,028 \\
30,925 \\
2,740,304 \\
242,900\end{array}$ & $\begin{array}{r}500 \\
98,285 \\
2,450 \\
358,253 \\
69,890\end{array}$ & $\begin{array}{r}19,241 \\
625 \\
120,924 \\
17,542\end{array}$ \\
\hline $\begin{array}{l}\text { Tyler......... } \\
\text { Upshur } \\
\text { Van Zandt..... } \\
\text { Victoria....... } \\
\text { Walker....... }\end{array}$ & $\begin{array}{r}129 \\
1,326 \\
377 \\
259 \\
1,266\end{array}$ & $\begin{array}{r}6,570 \\
63,804 \\
22,666 \\
24,168 \\
59,569\end{array}$ & $\begin{array}{r}155,475 \\
1,383,963 \\
791,425 \\
1,088,408 \\
1,399,985\end{array}$ & $\begin{array}{l}103,390 \\
991,673 \\
637,400 \\
957,720 \\
973,168\end{array}$ & $\begin{array}{r}52,085 \\
392,290 \\
154,025 \\
130,688 \\
426,817\end{array}$ & $\begin{array}{r}9,058 \\
72,420 \\
37,447 \\
40,128 \\
90,910\end{array}$ \\
\hline $\begin{array}{l}\text { Waller } \\
\text { Ward } \\
\text { Washington } \\
\text { Wharton }\end{array}$ & $\begin{array}{r}735 \\
5 \\
1,573 \\
1,394\end{array}$ & $\begin{array}{r}35,376 \\
76 \\
81,313 \\
58,506\end{array}$ & $\begin{array}{r}1,301,487 \\
10,100 \\
3,492,667 \\
3,627,718\end{array}$ & $\begin{array}{r}1,057,907 \\
7,475 \\
2,964,309 \\
3,095,321\end{array}$ & $\begin{array}{r}243,580 \\
2,625 \\
528,358 \\
532,397\end{array}$ & $\begin{array}{r}45,779 \\
250 \\
136,941 \\
178,155\end{array}$ \\
\hline $\begin{array}{l}\text { Wheeler } \\
\text { Wichita... } \\
\text { Wilbarger } \\
\text { Williamson }\end{array}$ & $\begin{array}{r}12 \\
16 \\
113 \\
450\end{array}$ & $\begin{array}{r}695 \\
966 \\
5,332 \\
27,344\end{array}$ & $\begin{array}{r}28,175 \\
87,275 \\
403,950 \\
2,187,971\end{array}$ & $\begin{array}{r}25,825 \\
78,275 \\
375,620 \\
1,977,012\end{array}$ & $\begin{array}{r}2,350 \\
9,000 \\
28,330 \\
210,959\end{array}$ & $\begin{array}{r}1,070 \\
1,655 \\
17,485 \\
71,960\end{array}$ \\
\hline $\begin{array}{l}\text { Wilson } \\
\text { Wise } \\
\text { Wood } \\
\text { Other counties. }\end{array}$ & $\begin{array}{r}76 \\
10 \\
533 \\
64\end{array}$ & $\begin{array}{r}6,518 \\
606 \\
32,170 \\
27,356\end{array}$ & $\begin{array}{r}221,900 \\
33,540 \\
933,427 \\
499,357\end{array}$ & $\begin{array}{r}189,510 \\
28,490 \\
699,918 \\
420,957\end{array}$ & $\begin{array}{r}32,390 \\
5,050 \\
233,509 \\
78,400\end{array}$ & $\begin{array}{r}8,220 \\
1,098 \\
42,734 \\
29,824\end{array}$ \\
\hline \multirow{3}{*}{ Total } & \multicolumn{6}{|c|}{ UTAF } \\
\hline & 5 & 37 & $\$ 24,200$ & $\$ 20,100$ & $\$ 4,100$ & $\$ 305$ \\
\hline & \multicolumn{6}{|c|}{ VERMONT } \\
\hline Total ............... & 22 & 3,812 & $\$ 118,700$ & $\$ 54,875$ & $\$ 68,825$ & $\$ 18,525$ \\
\hline
\end{tabular}


Table 38.-Farms Operated by Negroes-Number, Acreage, and Value of Specified Classes of Farm Property, by States and Codnties, 1930Continued

\begin{tabular}{|c|c|c|c|c|c|c|}
\hline \multirow{2}{*}{ STATE AND COUNTY } & \multirow{2}{*}{$\begin{array}{l}\text { Number } \\
\text { of farms }\end{array}$} & \multirow{2}{*}{$\begin{array}{c}\text { Land in } \\
\text { farms } \\
\text { (acres) }\end{array}$} & \multicolumn{3}{|c|}{ VALUEE OF LAND $\triangle$ ND BCILDINGS } & \multirow{2}{*}{$\begin{array}{l}\text { Value of } \\
\text { imple- } \\
\text { ments and } \\
\text { machinery }\end{array}$} \\
\hline & & & Total & Land alone & Buildings & \\
\hline & \multicolumn{6}{|c|}{ VIRGINIA } \\
\hline Total. & 39,698 & $2,039,656$ & $871,722,401$ & $\$ 48,154,526$ & $828,567,875$ & $\$ 3,885,540$ \\
\hline $\begin{array}{l}\text { Accomac } \\
\text { Albemarle } \\
\text { Alleghany } \\
\text { Amelia } \\
\text { Amberst }\end{array}$ & $\begin{array}{r}962 \\
465 \\
5 \\
726 \\
620\end{array}$ & $\begin{array}{l}43,581 \\
16,576 \\
172 \\
37,713 \\
28,261\end{array}$ & $\begin{array}{r}5,214,000 \\
1,030,177 \\
28,300 \\
1,228,209 \\
877,505\end{array}$ & $\begin{array}{r}3,735,410 \\
502,792 \\
18,200 \\
683,159 \\
509,502\end{array}$ & $\begin{array}{r}1,478,590 \\
527,385 \\
10,100 \\
545,050 \\
368,003\end{array}$ & $\begin{array}{r}288,696 \\
40,328 \\
1,002 \\
73,132 \\
32,721\end{array}$ \\
\hline $\begin{array}{l}\text { Appomattox } \\
\text { Augusta } \\
\text { Bath } \\
\text { Bedford } \\
\text { Bland }\end{array}$ & $\begin{array}{r}320 \\
99 \\
25 \\
709 \\
11\end{array}$ & $\begin{array}{r}18,291 \\
4,788 \\
1,222 \\
36,538 \\
1,094\end{array}$ & $\begin{array}{r}388,100 \\
352,975 \\
48,300 \\
1,198,164 \\
16,700\end{array}$ & $\begin{array}{r}210,985 \\
203,025 \\
31,625 \\
769,271 \\
11,600\end{array}$ & $\begin{array}{r}177,115 \\
149,950 \\
16,675 \\
428,893 \\
5,100\end{array}$ & $\begin{array}{r}20,539 \\
14,950 \\
5,145 \\
45,247 \\
885\end{array}$ \\
\hline $\begin{array}{l}\text { Botetourt } \\
\text { Brunswick } \\
\text { Buckingham } \\
\text { Campbell } \\
\text { Caroline }\end{array}$ & $\begin{array}{r}90 \\
1,329 \\
664 \\
713 \\
964\end{array}$ & $\begin{array}{r}3,291 \\
83,911 \\
39,370 \\
36,377 \\
53,606\end{array}$ & $\begin{array}{r}140,290 \\
1,835,393 \\
851,939 \\
1,018,050 \\
1,619,985\end{array}$ & $\begin{array}{r}78,940 \\
987,809 \\
493,239 \\
548,765 \\
910,560\end{array}$ & $\begin{array}{r}61,350 \\
847,584 \\
358,700 \\
469,285 \\
709,425\end{array}$ & $\begin{array}{r}3,173 \\
102,498 \\
46,500 \\
47,610 \\
88,060\end{array}$ \\
\hline $\begin{array}{l}\text { Carroll } \\
\text { Charles City } \\
\text { Charlotte } \\
\text { Chesterfield. } \\
\text { Clarke }\end{array}$ & $\begin{array}{r}15 \\
372 \\
841 \\
235 \\
26\end{array}$ & $\begin{array}{r}720 \\
13,287 \\
46,177 \\
9,753 \\
3,018\end{array}$ & $\begin{array}{r}39,100 \\
515,270 \\
1,277,668 \\
597,175 \\
226,960\end{array}$ & $\begin{array}{r}29,575 \\
330,580 \\
681,313 \\
307,850 \\
160,760\end{array}$ & $\begin{array}{r}9,525 \\
184,690 \\
596,355 \\
289,325 \\
66,200\end{array}$ & $\begin{array}{r}2,120 \\
43,225 \\
63,033 \\
35,104 \\
9,300\end{array}$ \\
\hline $\begin{array}{l}\text { Culpeper } \\
\text { Cumberland } \\
\text { Dinwlddie } \\
\text { Elizabeth City. } \\
\text { Essex }\end{array}$ & $\begin{array}{r}286 \\
553 \\
933 \\
56 \\
633\end{array}$ & $\begin{array}{r}17,462 \\
33,140 \\
63,054 \\
1,236 \\
30,574\end{array}$ & $\begin{array}{r}714,290 \\
708,040 \\
1,381,040 \\
154,765 \\
1,062,090\end{array}$ & $\begin{array}{r}396,245 \\
377,278 \\
837,256 \\
95,553 \\
561,373\end{array}$ & $\begin{array}{r}318,045 \\
330,762 \\
543,784 \\
59,212 \\
500,717\end{array}$ & $\begin{array}{r}53,765 \\
43,672 \\
84,859 \\
9,209 \\
96,089\end{array}$ \\
\hline $\begin{array}{l}\text { Fairfax } \\
\text { Fauquier } \\
\text { Floyd } \\
\text { Fluvanna } \\
\text { Franklin }\end{array}$ & $\begin{array}{r}85 \\
310 \\
74 \\
353 \\
538\end{array}$ & $\begin{array}{r}2,363 \\
19,886 \\
3,835 \\
14,089 \\
38,190\end{array}$ & $\begin{array}{l}361,880 \\
980,616 \\
132,546 \\
482,651 \\
830,760\end{array}$ & $\begin{array}{r}214,055 \\
554,091 \\
97,821 \\
237,981 \\
523,343\end{array}$ & $\begin{array}{r}147,825 \\
426,525 \\
34,725 \\
244,670 \\
307,417\end{array}$ & $\begin{array}{r}13,350 \\
35,337 \\
5,908 \\
35,049 \\
28,261\end{array}$ \\
\hline $\begin{array}{l}\text { Frederick } \\
\text { Giles. } \\
\text { Gloucester } \\
\text { Goochland } \\
\text { Grayson }\end{array}$ & $\begin{array}{r}21 \\
28 \\
514 \\
493 \\
78\end{array}$ & $\begin{array}{r}1,972 \\
784 \\
12,918 \\
22,365 \\
2,092\end{array}$ & $\begin{array}{r}191,900 \\
37,130 \\
801,730 \\
549,220 \\
191,390\end{array}$ & $\begin{array}{r}142,800 \\
24,745 \\
397,480 \\
290,745 \\
135,455\end{array}$ & $\begin{array}{r}49,100 \\
12,385 \\
404,250 \\
258,475 \\
55,935\end{array}$ & $\begin{array}{r}3,995 \\
2,212 \\
64,285 \\
23,700 \\
4,982\end{array}$ \\
\hline $\begin{array}{l}\text { Greene } \\
\text { Greensville. } \\
\text { Halifax } \\
\text { Hanover } \\
\text { Henrico....... }\end{array}$ & $\begin{array}{r}107 \\
788 \\
2,380 \\
559 \\
168\end{array}$ & $\begin{array}{r}3,098 \\
50,505 \\
127,457 \\
28,681 \\
4,878\end{array}$ & $\begin{array}{r}173,100 \\
1,292,010 \\
3,446,898 \\
1,027,030 \\
414,195\end{array}$ & $\begin{array}{r}98,045 \\
782,260 \\
2,153,268 \\
530,495 \\
276,635\end{array}$ & $\begin{array}{r}75,055 \\
509,750 \\
1,293,630 \\
496,535 \\
137,560\end{array}$ & $\begin{array}{r}8,712 \\
87,447 \\
134,371 \\
89,333 \\
21,122\end{array}$ \\
\hline $\begin{array}{l}\text { Henry } \\
\text { Highland } \\
\text { Isle of Wight } \\
\text { James City } \\
\text { King and Queen }\end{array}$ & $\begin{array}{l}469 \\
11 \\
469 \\
182 \\
606\end{array}$ & $\begin{array}{r}28,309 \\
1,715 \\
27,857 \\
5,762 \\
30,059\end{array}$ & $\begin{array}{r}696,685 \\
25,800 \\
900,083 \\
336,500 \\
794,779\end{array}$ & $\begin{array}{r}354,535 \\
18,225 \\
643,188 \\
171,711 \\
395,780\end{array}$ & $\begin{array}{r}342,150 \\
7,575 \\
256,895 \\
164,789 \\
398,999\end{array}$ & $\begin{array}{r}36,125 \\
4,911 \\
21,761 \\
17,941 \\
66,103\end{array}$ \\
\hline $\begin{array}{l}\text { King George } \\
\text { King William } \\
\text { Lancaster } \\
\text { Lee } \\
\text { Loudoun }\end{array}$ & $\begin{array}{r}260 \\
414 \\
415 \\
29 \\
77\end{array}$ & $\begin{array}{r}12,731 \\
20,289 \\
9,069 \\
1,262 \\
6,017\end{array}$ & $\begin{array}{r}482,948 \\
540,125 \\
418,355 \\
83,125 \\
401,345\end{array}$ & $\begin{array}{r}254,678 \\
271,355 \\
205,210 \\
60,725 \\
237,090\end{array}$ & $\begin{array}{r}228,270 \\
268,770 \\
213,145 \\
22,400 \\
164,255\end{array}$ & $\begin{array}{r}38,757 \\
34,312 \\
58,925 \\
1,072 \\
17,725\end{array}$ \\
\hline $\begin{array}{l}\text { Louisa } \\
\text { Lunenburg } \\
\text { Madison } \\
\text { Mathews } \\
\text { Mecklenburg }\end{array}$ & $\begin{array}{r}740 \\
843 \\
276 \\
214 \\
2,275\end{array}$ & $\begin{array}{r}39,442 \\
48,993 \\
12,584 \\
2,263 \\
110,539\end{array}$ & $\begin{array}{r}1,042,839 \\
1,244,230 \\
488,034 \\
273,330 \\
3,816,692\end{array}$ & $\begin{array}{r}552,769 \\
692,025 \\
266,289 \\
105,735 \\
2,263,607\end{array}$ & $\begin{array}{r}490,070 \\
552,205 \\
221,745 \\
167,595 \\
1,553,085\end{array}$ & $\begin{array}{r}57,497 \\
61,510 \\
26,192 \\
21,646 \\
183,058\end{array}$ \\
\hline $\begin{array}{l}\text { Middlesex } \\
\text { Montgomery } \\
\text { Nansemond } \\
\text { Nelson } \\
\text { New Kent }\end{array}$ & $\begin{array}{r}485 \\
98 \\
918 \\
406 \\
147\end{array}$ & $\begin{array}{r}11,978 \\
3,469 \\
40,117 \\
17,669 \\
8,139\end{array}$ & $\begin{array}{r}637,390 \\
237,900 \\
1,865,160 \\
710,077 \\
222,500\end{array}$ & $\begin{array}{r}312,445 \\
133,855 \\
1,263,473 \\
459,552 \\
145,240\end{array}$ & $\begin{array}{r}324,945 \\
104,045 \\
601,687 \\
250,525 \\
77,260\end{array}$ & $\begin{array}{r}63,455 \\
5,973 \\
67,244 \\
27,326 \\
13,101\end{array}$ \\
\hline
\end{tabular}


Table 38.-Farms Operated by Negroes-Number, Acreage, and Value of Specified Classes of Farm Property, by States and Counties, 1930Continued

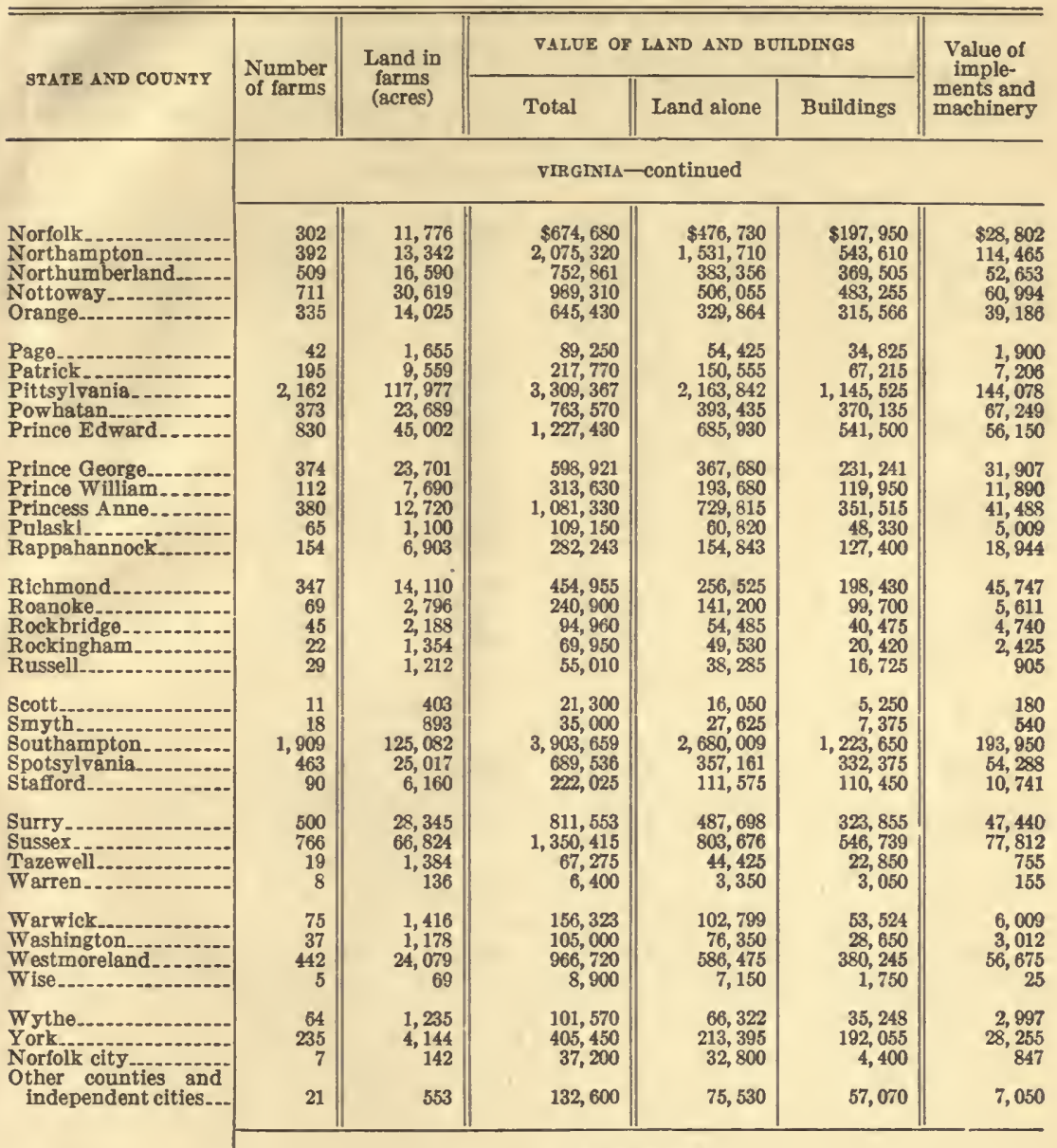

WASHINOTON

\begin{tabular}{|c|c|c|c|c|c|c|}
\hline \multirow[b]{2}{*}{ Total } & \\
\hline & 73 & 9,425 & 8356,705 & 8258,568 & 898,137 & 822,740 \\
\hline \multirow[t]{3}{*}{$\begin{array}{l}\text { Douglas. } \\
\text { King } \\
\text { Lewis. } \\
\text { Yakima } \\
\text { Other counties. }\end{array}$} & $\begin{array}{r}5 \\
7 \\
10 \\
21 \\
30\end{array}$ & $\begin{array}{r}3,892 \\
61 \\
285 \\
1,310 \\
3,877\end{array}$ & $\begin{array}{r}17,905 \\
17,600 \\
33,250 \\
138,450 \\
149,500\end{array}$ & $\begin{array}{r}15,580 \\
10,900 \\
18,100 \\
105,418 \\
108,570\end{array}$ & $\begin{array}{r}2,325 \\
6,700 \\
15,150 \\
33,032 \\
40,930\end{array}$ & $\begin{array}{l}1,650 \\
1,480 \\
3,900 \\
6,005 \\
9,705\end{array}$ \\
\hline & \multicolumn{6}{|c|}{ WEST VIRGINIA } \\
\hline & 490 & 28,013 & $81,480,626$ & 8905,398 & 8575,235 & 847,007 \\
\hline $\begin{array}{l}\text { Barbour } \\
\text { Berkeiey. } \\
\text { Boone } \\
\text { Braxton } \\
\text { Cabell }\end{array}$ & $\begin{array}{r}79 \\
15 \\
5 \\
9 \\
8\end{array}$ & $\begin{array}{r}2,768 \\
733 \\
231 \\
660 \\
486\end{array}$ & $\begin{array}{l}95,300 \\
83,400 \\
17,900 \\
14,500 \\
63,500\end{array}$ & $\begin{array}{r}75,658 \\
52,600 \\
7,800 \\
10,600 \\
36,650\end{array}$ & $\begin{array}{r}19,642 \\
30,800 \\
10,100 \\
3,900 \\
26,850\end{array}$ & $\begin{array}{r}2,345 \\
2,110 \\
525 \\
345 \\
3,257\end{array}$ \\
\hline
\end{tabular}


Table 38. - Farms Operated by Negroes-Number, Acreage, and Value of Specified Classes of Farm Property, by States and Counties, $1930-$ Continued

\begin{tabular}{|c|c|c|c|c|c|c|}
\hline \multirow{2}{*}{ STATE AND COUNTY } & \multirow{2}{*}{$\begin{array}{l}\text { Number } \\
\text { of farms }\end{array}$} & \multirow{2}{*}{$\begin{array}{l}\text { Land in } \\
\text { farms } \\
\text { (acres) }\end{array}$} & \multicolumn{3}{|c|}{ VALUE OF LAND AND BUILDINGS } & \multirow{2}{*}{$\begin{array}{l}\text { Value of } \\
\text { imple- } \\
\text { ments and } \\
\text { machinery }\end{array}$} \\
\hline & & & Total & Land alone & Buildings & \\
\hline \multicolumn{7}{|c|}{ WEST VIRGINIA-contlnued } \\
\hline $\begin{array}{l}\text { Fayette } \\
\text { Grant } \\
\text { Greenbrier } \\
\text { Hampshire } \\
\text { Jefferson }\end{array}$ & $\begin{array}{r}33 \\
6 \\
24 \\
5 \\
37\end{array}$ & $\begin{array}{r}873 \\
837 \\
1,518 \\
234 \\
3,389\end{array}$ & $\begin{array}{r}\$ 98,300 \\
6,700 \\
64,700 \\
5,000 \\
383,130\end{array}$ & $\begin{array}{r}\$ 46,200 \\
5,050 \\
43,275 \\
2,925 \\
207,530\end{array}$ & $\begin{array}{r}\$ 52,100 \\
1,650 \\
21,425 \\
2,075 \\
175,600\end{array}$ & $\begin{array}{r}\$ 3,485 \\
300 \\
1,670 \\
100 \\
10,435\end{array}$ \\
\hline $\begin{array}{l}\text { Kanawha } \\
\text { McDoweli } \\
\text { Marion } \\
\text { Mercer } \\
\text { Monongalia }\end{array}$ & $\begin{array}{r}31 \\
8 \\
6 \\
23 \\
6\end{array}$ & $\begin{array}{r}1,190 \\
1,013 \\
426 \\
677 \\
123\end{array}$ & $\begin{array}{r}122,573 \\
25,550 \\
.11,800 \\
39,700 \\
10,400\end{array}$ & $\begin{array}{r}84,295 \\
15,500 \\
9,300 \\
25,525 \\
6,850\end{array}$ & $\begin{array}{r}38,278 \\
10,050 \\
2,500 \\
14,175 \\
3,550\end{array}$ & $\begin{array}{r}3,644 \\
493 \\
275 \\
1,021 \\
210\end{array}$ \\
\hline $\begin{array}{l}\text { Monroe } \\
\text { Pendleton } \\
\text { Pocahontas } \\
\text { Raleigh } \\
\text { Summers. }\end{array}$ & $\begin{array}{r}43 \\
8 \\
17 \\
6 \\
37\end{array}$ & $\begin{array}{r}2,192 \\
438 \\
1,282 \\
512 \\
2,453\end{array}$ & $\begin{array}{l}67,100 \\
12,800 \\
51,600 \\
11,500 \\
61,800\end{array}$ & $\begin{array}{r}42,375 \\
9,165 \\
31,650 \\
7,900 \\
44,925\end{array}$ & $\begin{array}{r}24,725 \\
3,635 \\
19,950 \\
3,600 \\
16,875\end{array}$ & $\begin{array}{r}2,435 \\
383 \\
985 \\
1,610 \\
2,160\end{array}$ \\
\hline \multirow[t]{2}{*}{$\begin{array}{l}\text { Taylor } \\
\text { Wirt } \\
\text { Wyoming } \\
\text { Other counties }\end{array}$} & $\begin{array}{r}43 \\
6 \\
6 \\
29\end{array}$ & $\begin{array}{r}2,702 \\
434 \\
182 \\
2,660\end{array}$ & $\begin{array}{r}100,125 \\
8,800 \\
8,800 \\
115,650\end{array}$ & $\begin{array}{r}63,200 \\
4,850 \\
6,225 \\
65,345\end{array}$ & $\begin{array}{r}36,925 \\
3,950 \\
2,575 \\
50,305\end{array}$ & $\begin{array}{r}3,291 \\
120 \\
152 \\
5,656\end{array}$ \\
\hline & \multicolumn{6}{|c|}{ WISCONSIN } \\
\hline Total & 55 & 5,295 & $\$ 843,105$ & $\$ 228,435$ & $\$ 114,670$ & 825,921 \\
\hline \multirow[t]{2}{*}{$\begin{array}{l}\text { Vernon } \\
\text { Other counties......... }\end{array}$} & $\begin{array}{l}18 \\
37\end{array}$ & $\begin{array}{l}1,899 \\
3,396\end{array}$ & $\begin{array}{l}126,400 \\
216,705\end{array}$ & $\begin{array}{r}90,155 \\
138,280\end{array}$ & $\begin{array}{l}36,245 \\
78,425\end{array}$ & $\begin{array}{r}9,750 \\
16,171\end{array}$ \\
\hline & \multicolumn{6}{|c|}{ WYOMING } \\
\hline Total $\ldots . . . . . . . . .$. & 12 & 10,925 & $\$ 139,020$ & $\$ 123,870$ & $\$ 15,150$ & 87,825 \\
\hline
\end{tabular}




Pressboard

Pamphlet

Binder

Gaylord Bros., Inc.

Makers

Syracuse, N. Y.

PAT, LAN. 21. 1908 
UNIVERSITY OF ILLINOIS-URBANA

325.26UN333F
FIFTEENTH CENSUS OF THE UNITED STATES WA

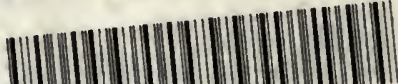

- 0112018879095 